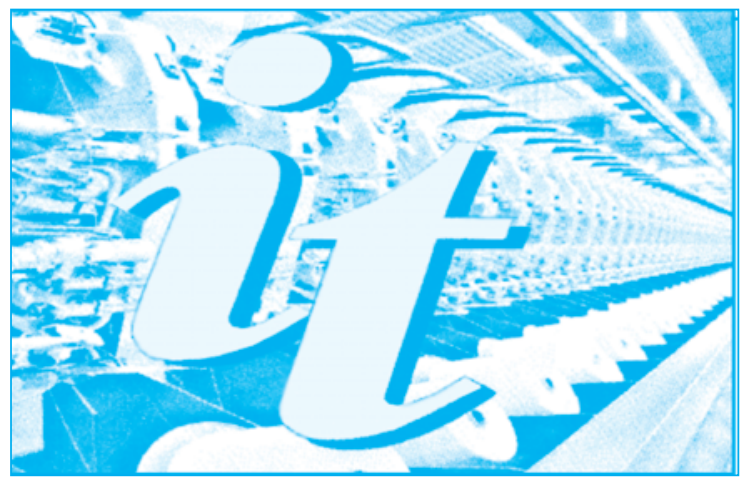

ISI rated journal, included in the ISI Master Journal List of the Institute of Science Information, Philadelphia, USA, starting with vol. 58, no. 1/2007, with impact factor 0.504 and AIS 0.046 in 2018

The journal is indexed by CrossRef, starting with no. 1/2017 having the title DOI: https://doi.org/10.35530/IT.

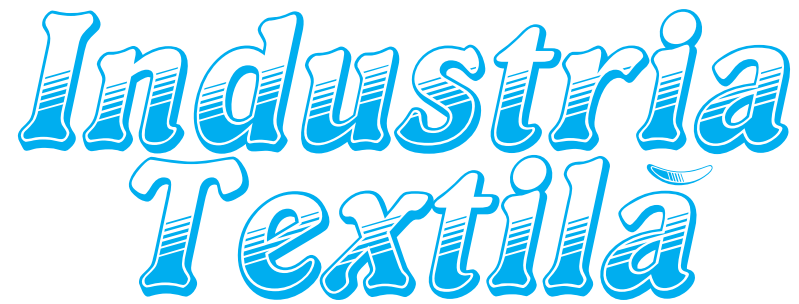

ISSN $1222-5347$

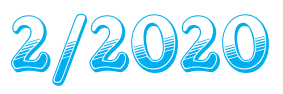

Edited in 6 issues per year, indexed and abstracted in: Science Citation Index Expanded (SciSearch $\left.{ }^{\circledR}\right)$, Materials Science Citation Index ${ }^{\circledR}$, Journal Citation Reports/Science Edition, World Textile Abstracts, Chemical Abstracts, VINITI, Scopus, Toga FIZ technik ProQuest Central, Crossref

Edited with the Romanian Ministry of Education and Research support

\section{INIDUSTRIA TEXTILA EIDITDIRIAL BDARID:}

Dr. Eng. CARMEN GHITULEASA GENERAL MANAGER

National R\&D Institute for Textiles and Leather Bucharest, Romania

Dr. Eng. SABINA OLARU CS II, EDITOR IN CHIEF

National R\&D Institute for Textiles and Leather Bucharest, Romania

Dr. Eng. EMILIA VISILEANU CS I, HONORIFIC EDITOR

National R\&D Institute for Textiles and Leather, Bucharest, Romania Prof. XIANYI ZENG

Ecole Nationale Superieure des Arts et Industries Textiles (ENSAIT), France

Prof. Dr. Eng. LUIS ALMEIDA University of Minho, Portugal

Prof. Dr. STJEPANOVIČ ZORAN University of Maribor, Faculty of Mechanical Engineering, Department of Textile Materials and Design, Maribor, Slovenia Lec. ALEXANDRA DE RAEVE University College Ghent, Fashion, Textile and Wood Technology Department, Belgium

Prof. Dr. Eng. ERHAN ÖNER

Marmara University, Turkey

Prof. Dr. S. MUGE YUKSELOGLU

Marmara University, Turkey

$$
\text { Dr. MAZARI ADNAN }
$$

ASSISTANT PROFESSOR

Department of Textile Clothing, Faculty of Textile Engineering, Technical University of Liberec Czech Republic

Dr. AMINODDIN HAJI

PhD, MSc, BSc, Textile Chemistry and Fiber Science ASSISTANT PROFESSOR

Textile Engineering Department

Yazd University, Yazd, Iran

Prof. Dr. Eng. CARMEN LOGHIN PRO-RECTOR

Faculty of Industrial Design and Business Management, Technical University

"Gh. Asachi", laşi, Romania

Associate Prof. Dr. Eng. MARIANA URSACHE DEAN

Faculty of Industrial Design and Business Management, Technical University "Gh. Asachi", laşi, Romania

Prof. Dr. GELU ONOSE CS I

"Carol Davila" University of Medicine and Pharmacy, Bucharest, Romania

Prof. Dr. DOINAI. POPESCU The Bucharest University of Economic Studies, Bucharest, Romania

Prof. Dr. MARGARETA STELEA FLORESCU

The Bucharest University of Economic Studies, Bucharest, Romania
SHU-QIANG LIU, KAI-WEN WANG, YA-RU YANG, HUI-MIN LI, GAI-HONG WU, JUAN-JUAN YU, MING-FANG LIU, YAO ZHANG, PENG WANG, JIE ZHANG,

AN XU, XIAO-LONG YIN, FU LI, MAN ZHANG

Degradation behaviour in vitro of poly L-lactic acid (PLLA)/polycaprolactone (PCL) masterbatch

KARA SUKRAN

Comparison of sewn fabric bending rigidities obtained by heart loop method: effects of different stitch types and seam directions

IOAN OANA, LILIANA INDRIE, AURELIA ONET, DORINA OANA,

DORINA CAMELIA ILIES, GRIGORE VASILE HERMAN, ALEXANDRU ILIES, FLORIN MARCU

Preserving textile objects in Romanian wooden churches. Case study

of the heritage wooden church form Oradea, Romania

KALKANCI MIHRIBAN

Qualitative classification of woven fabrics produced from recycled threads of cotton and blends

SLAVICA MILETIĆ, ŠIMŠIĆ ZDENKA STANOJEVIĆ, IVAN JOVANOVIĆ, MILAN RADIVOJEVIĆ, VESNA CONIĆ

AHP analysis of organizational culture in textile companies in Serbia

SIKANDER ABBAS BASRA, ABDUL WAQAR RAJPUT, BILAL ZAHID,

NORINA ASFAND, ZEESHAN AZAM, HAFSA JAMSHAID

Investigations of stretch and recovery properties of knitted socks

EFTALEA CĂRPUȘ, ANGELA DOROGAN, CRISTINA STROE

Textile packaging - the connection between science and health

SHARIF RABIA, MOHSIN MUHAMMAD, RAMZAN NAVEED,

AHMAD SYED WAQAS, HAJI GHULAM QUTAB

Development of free fluorine and formaldehyde oil and water repellent finishes

for cotton fabrics through polymerization of bio-based stearic acid with

carboxylic acids

IULIANA DUMITRESCU, OVIDIU-GEORGE IORDACHE, ELENA-CORNELIA MITRAN, ELENA PERDUM, IRINA-MARIANA SĂNDULACHE, LUCIA-OANA SECĂREANU,

ARCADII SOBETKII

Characterization of fabrics coated with doped $\mathrm{TiO}_{2}$-graphene

BOGDAN-IULIAN DOROFTEI, MIRCEA DEGERATU, GEORGETA BANDOC

OVIDIU-GEORGE IORDACHE, IOANA CORINA MOGA

Researches on the use of textile materials for protection against soil erosion

TEZCAN ERDEM, BÜYÜKAKINCI BANU YEŞIM

Antibacterial properties of wool fabrics treated with 8-hydroxyquinoline and boron compounds

DU ZHAOQUN, XU QIAOLI, GU LONGXIN, ZHENG DONGMING, WANG QICAI Tensile and bending properties of flexible auxetic re-entrant honeycomb structures made by $3 \mathrm{D}$ printing

AHMAD AFTAB, HUSSAIN AMJAD, MUGHAL MOHAMMAD, MUFTI NADEEM, SALEEM MUHAMMAD, AHRAM TAREQ

Perceived stress: role and levels of demographics - a cross-sectional study of textile industry employees

LAURA CHIRILĂ, GABRIELA CRISTINA CONSTANTINESCU, ANGELA DANILA, ALINA POPESCU, ROXANA RODICA CONSTANTINESCU,

IRINA-MARIANA SĂNDULACHE

Functionalization of textile materials with bioactive polymeric systems based on propolis and cinnamon essential oil

MONICA DUDIAN, DANIELA VASILE, MARGARETA STELA FLORESCU

Romania's participation in FP7 and H2020: a comparative approach in the context of the new EU member countries

Web of Science Journal Category: Materials Science, Textiles

Aknowledged in Romania, in the Engineering sciences domain, by the National Council of the Scientific Research from the Higher Education (CNCSIS), in group $\mathbf{A}$ 


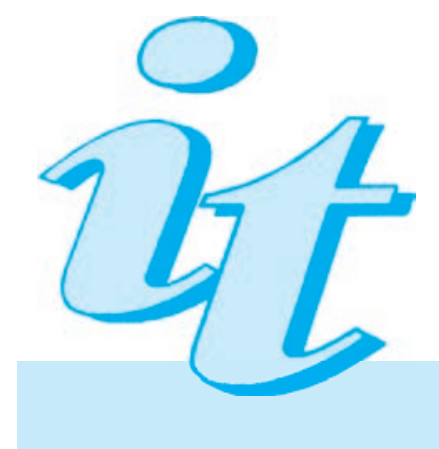

Scientific reviewers for the papers published in this number:

Dr. Syed Rizvi, Research \& Development Manager, RONCO, Canada

Prof. Pablo Diaz Garcia, University of Valencia EPSA, Spain

Dr. Usman Ali, Institute of Frontier Materials, Deakin University, Australia

PhD. Muhammad Irfan Siyal, Department of Civil and Environmental Engineering, Hanyang University, Korea

Dr. Fenjuan Shao, Donghua University, China

Dr. Hongyan Wu, Hebei University of Science and Technology, China

PhD. Nareerut Jariyapunya, Technical University of Liberec, Textile Engineering Faculty, Clothing Technology Department, Czech Republic

Prof. Dr. Onder Yucel, Bayındır Vocational Training School, Ege University, Turkey

Prof. Dr. Ayca Gurarda, Uludağ University, Textile Engineering Department, Turkey

Dr. Sun Fengxin, Jiangnan University, China

Prof. Dr. Eng. Alexandru Popa, University “Aurel Vlaicu” from Arad, Faculty of Engineering, Romania

Prof. Nihal Sökmen, Marmara University, Department of Textile Engineering, Turkey

Assoc. Prof. Hakan Ozdemir, Dokuz Eylül University, Department of Textile Engineering, Turkey

Assoc. Prof. Zümrüt Bahadır Ünal, Ege University, Department of Textile Engineering, Turkey

Prof. Dr. Ventsislav Ivanov, University of Mining and Geology "St. Ivan Rilski”, Bulgaria

Prof. Dr. Aurelia Litvin, State Agrarian University of Moldova, Department of Business and Aministration, Moldova Republic

Dr. Hesam Dehghani, Mining engineering, Hamedan University of Technology, Hamedan, Iran

Ph.D. Matej Drobne, Valji d.o.o., Slovenia

Assoc. Prof. Muhammed Kahveci, Istanbul Technical University, Faculty of Science and Letter, Department of Chemistry, Turkey

Assist. Prof. Dr. Hafsa Jamshaid, National Textile University, Pakistan

Assist. Prof. Dr. Abdul Waqar Rajput, BZU College of Textile Engineering, Pakistan

\begin{tabular}{|c|}
\hline EDITORIAL STAFF \\
General Manager: Dr. Eng. Carmen Ghițuleasa \\
Editor-in-chief: Dr. Eng. Sabina Olaru \\
Onorific editor: Dr. Eng. Emilia Visileanu \\
Graphic designer: Florin Prisecaru \\
Translator: Cătălina Costea \\
Site administrator: Constantin Dragomir \\
e-mail: industriatextila @ incdtp.ro \\
\hline
\end{tabular}

INDUSTRIA TEXTILA journal, edited by INCDTP BUCHAREST, implements and respects Regulation 2016/679/EU on the protection of individuals with regard to the processing of personal data and on the free movement of such data ("RGPD"). For information, please visit the Personal Data Processing Protection Policy link or e-mail to DPO rpd@incdtp.ro

Journal edited in colaboration with Editura AGIR, 118 Calea Victoriei, sector 1, Bucharest, tel./fax: 021-316.89.92; 021-316.89.93; e-mail: editura@agir.ro,www.edituraagir.ro 


\title{
Degradation behaviour in vitro of poly L-lactic acid (PLLA)/polycaprolactone (PCL) masterbatch
}

\author{
DOI: 10.35530/IT.071.02.1628
}

\author{
SHU-QIANG LIU \\ KAI-WEN WANG \\ YA-RU YANG \\ HUI-MIN LI \\ GAI-HONG WU
}

\author{
JUAN-JUAN YU \\ MING-FANG LIU \\ YAO ZHANG \\ PENG WANG
}

\author{
JIE ZHANG \\ AN XU \\ XIAO-LONG YIN \\ FU LI \\ MAN ZHANG
}

\section{ABSTRACT - REZUMAT}

\section{Degradation behaviour in vitro of poly L-lactic acid (PLLA)/polycaprolactone (PCL) masterbatch}

In order to prepare the absorbable medical textile material with different degradation rates, two biopolymers of poly L-lactic acid (PLLA) and polycaprolactone (PCL) with different degradation rates, were mixed in different proportions, and made into PLLA/PCL masterbatch. The experiment of degradation in vitro was conducted to reveal the degradation behaviour of PLLA/PCL masterbatch, and the characteristics of masterbatch in degradation, such as surface morphology, chemical structure, crystallization, mass loss and strength, were analyzed. The results indicated that the surface of PLLA/PCL masterbatch was etched in degradation, and the larger proportion of PCL, the less etching and slower degradation. The ester bonds were hydrolyzed firstly, and the crystallization region in PLLA/PCL masterbatch was destroyed gradually to form a non-crystalline region in degradation. The degradation rate of PLLA in composite masterbatch was faster than that of PCL. With increasing of PCL involved in masterbatch, the mass loss rate of masterbatch in degradation decreased. In addition, the more PCL involved in composite masterbatch, the lower breaking strength.

Keywords: poly L-lactic acid (PLLA), polycaprolactone (PCL), masterbatch, degradation behaviour, in vitro degradation

\section{Comportamentul de degradare in vitro al amestecului preliminar de acid poli-L-lactic (PLLA)/policaprolactonă} (PCL)

În realizarea materialului textil absorbabil pentru domeniul medical ce prezintă diferite rate de degradare, doi biopolimeri de acid L-lactic (PLLA) și policaprolactonă (PCL) au fost combinați în diferite proporții și transformați în amestec preliminar de PLLA/PCL. Experimentul degradării in vitro a fost realizat pentru a investiga comportamentul de degradare al amestecului preliminar PLLA/PCL și au fost analizate caracteristicile amestecului preliminar în degradare, cum ar fi morfologia suprafaței, structura chimică, cristalizarea, pierderea de masă și rezistența la rupere. Rezultatele au indicat că suprafața amestecului prelimiar PLLA/PCL a fost corodată în timpul degradării, iar cu cât cantitatea de PCL a fost mai mare, cu atât degradarea a fost mai lentă. Legăturile esterice au fost hidrolizate primele, iar zona de cristalizare a amestecului preliminar PLLA/PCL a fost distrusă treptat pentru a forma o zonă necristalină în timpul degradării. Rata de degradare a PLLA în amestecul preliminar compozit a fost mai rapidă decât cea a PCL. Odată cu creșterea cantității de PCL în amestecul preliminar, pierderea de masă în timpul degradării a scăzut. În plus, cu cât cantitatea de PCL este mai mare în amestecul preliminar compozit, cu atât este mai mică rezistența la rupere.

Cuvinte-cheie: acid poli-L-lactic (PLLA), policaprolactonă (PCL), amestec preliminar, comportament de degradare, degradare in vitro

\section{INTRODUCTION}

The masterbatch of synthetic polymer biomaterials, including poly L-lactic acid (PLLA), polycaprolactone (PCL) and so on, possesses excellent biocompatibility, degradation absorptivity in body, good strength and others. They can be made into some absorbable textile products such as the tissue engineering scaffold, the absorbable suture and the temporary antiadhesion membrane, using electrostatic spinning, melt spinning, three-dimensional woven, knitting and other technologies [1-3].

With the gradual degradation and absorption of the absorbable textile product implanted in the body, the tissue cells grow gradually clinging to the absorbable textile product, and the wound will be healed gradu- ally [4-6]. The degradation of the absorbable textile product needs to be matched with the healing time of tissue.

In order to adjust degradation rate of these absorbable textile products, different methods are adopted.

Through adjusting size of the absorbable textile products, the degradation rate can be controlled. For instance, Scaffaro et al. [7] adjusted the fiber's fineness to change the degradation rate of poly (lactic acid) membrane. However, the size of bioabsorbable products, such as absorbable suture, vascular stent and so on, just have a narrow adjustable range, so the adjustable range of degradation rate is very narrow. The degradation rate is adjusted by grafting some simple chemical groups onto the molecular chain 
segment of the absorbable textile products. For instance, Qian et al. [8] grafted the polar groups onto the end groups or pendant groups of polyester molecular chains, so that the hydrolysis rate of polyester polymers was accelerated, and the number of polar groups was positively correlated with the polymer hydrolysis rate. However, this method involves a complex chemical process, and it is difficult to control the degradation rate with high precision and accuracy.

Some substances, such as plasticizer, hydrophilic agent and so on, are mixed with the absorbable textile products to change the degradation rate. For instance, Choi et al. [9] added poly(ethylene glycol) into poly(lactic acid), and accelerated the degradation of poly(lactic acid). However, the substances added in the absorbable products are mostly low molecular weight, so that the mechanical properties of the absorbable products are often worsened and decreased.

In this article, we selected two biomaterials of poly L-lactic acid (PLLA) and polycaprolactone (PCL) with different degradation rates, to blend and then form PLLA/PCL composite masterbatch. Both PLLA and PCL possess many advantages, such as good biocompatibility in vivo, small tissue reaction and no rejection reaction [10-11]. Besides, the degradation rate of PLLA is faster than that of $P C L$, and the degradation rate of PLLA/PCL composite masterbatch can be adjusted by changing the mixing ratio of PLLA and PCL. In addition, PLLA and PCL are both polyester biomaterials and have good compatibility, so they are easy to mix with each other, which is in favour of getting sufficient mechanical properties for composite masterbatch [12-13].

\section{EXPERIMENTAL WORK}

\section{Materials}

The poly L-lactic acid (PLLA, $\left.\left(\mathrm{C}_{6} \mathrm{H}_{8} \mathrm{O}_{4}\right)_{n}\right)$ with 51500 viscous molecular weight, and the polycaprolactone (PCL, $\left.\left(\mathrm{C}_{6} \mathrm{H}_{10} \mathrm{O}_{2}\right)_{n}\right)$ with 48900 viscous molecular weight, are both produced by Natureworks Company (USA).

\section{Experimental process}

The PLLA and PCL are mixed in different proportions, such as 100/0, 90/10, 80/20, 70/30, 60/40, 50/50, 40/60, 30/70, 20/80, 10/90 and 0/100. $5 \mathrm{~g}$ mixture of PLLA/PCL is put into $60 \mathrm{~mL}$ dichloromethane $\left(\mathrm{CH}_{2} \mathrm{Cl}_{2}\right)$, and they are vibrated in a Water-bathing Constant Temperature Vibrator (SHA-C, Ningbo Textile Instrument Factory) at $25^{\circ} \mathrm{C}$ for $4 \mathrm{~h}$, to dissolve the PLLA and PCL fully. After that, the solution of PLLA and PCL is poured into a glass trough, and they are horizontally put into ventilation under normal temperature, to make the solvent of dichloromethane $\left(\mathrm{CH}_{2} \mathrm{Cl}_{2}\right)$ volatilize completely. So the PLLA/PCL composite materials are cut into masterbatch $(1 \mathrm{~mm}$ $\times 2 \mathrm{~mm} \times$ length), and then the structure and property of the masterbatch are tested and measured.

\section{Scanning electron microscopy (SEM)}

Scanning electron microscopy (SEM) investigations were performed on a JEM2100F (Kabuskiki Kaisha, Japan) at $7 \mathrm{kV}$ accelerating voltage to evaluate the morphologies of PLLA/PCL masterbatch samples.

Fourier transform infrared spectroscopy (FTIR)

The chemical structure of PLLA/PCL masterbatch samples were dedicated by FTIR. The infrared spectra were obtained via Fourier Transform Infrared Spectroscopy (FTIR; TL-8000) with a resolution of $4 \mathrm{~cm}^{-1}$ that scanned 50 times from 600 to $4000 \mathrm{~cm}^{-1}$ at room temperature.

\section{X-ray diffraction (XRD)}

X-ray diffractometer (TD-3700, Dandong Tongda Technology Co., LTD.) was used to measure the XRD spectrum of PLLA/PCL masterbatch samples, under conditions of $2 \theta$ angle of $10^{\circ}-50^{\circ}, 0.05^{\circ}$ step-angle, $30 \mathrm{KV}$ tube-voltage and $25 \mathrm{~mA}$ tube current intensity.

\section{Mass loss rate testing}

The mass of PLLA/PCL masterbatch sample, before the degradation test in vitro, was recorded as $M_{0}$. After the degradation test in vitro, the drying mass of sample was recorded as $M_{1}$. So the mass loss rate, recorded as $W$, was calculated according to equation (1).

$$
W=\frac{M_{0}-M_{1}}{M_{0}} \times 100 \%
$$

\section{Mechanics performance testing}

The mechanical properties of PLLA/PCL masterbatch samples $(1 \mathrm{~mm} \times 2 \mathrm{~mm} \times 100 \mathrm{~mm}$ ) were obtained via a Strength Tester (TG(B)026D, Wenzhou Darong Textile Standard Instrument Factory).

\section{Degradation test in vitro}

The degradation behaviour of PLLA/PCL masterbatch samples was characterized through degradation-test in vitro. The "Hanks" solution, which simulated the body fluid, was prepared according to the recipe of $1.0 \mathrm{~g} / \mathrm{L} \mathrm{C}_{6} \mathrm{H}_{6} \mathrm{O}_{6}, 8.0 \mathrm{~g} / \mathrm{L} \mathrm{NaCl}, 0.4 \mathrm{~g} / \mathrm{L} \mathrm{KCl}$, $0.14 \mathrm{~g} / \mathrm{L} \mathrm{CaCl}, 0.1 \mathrm{~g} / \mathrm{L} \mathrm{MgCl} \cdot 6 \mathrm{H}_{2} \mathrm{O}, 0.06 \mathrm{~g} / \mathrm{L}$ $\mathrm{MgSO}_{4} \cdot 7 \mathrm{H}_{2} \mathrm{O}, 0.06 \mathrm{~g} / \mathrm{L} \mathrm{KH}_{2} \mathrm{PO}_{4}, 0.06 \mathrm{~g} / \mathrm{L} \mathrm{Na}{ }_{2} \mathrm{HPO}_{4}$ and $0.35 \mathrm{~g} / \mathrm{L} \mathrm{Na}_{2} \mathrm{HCO}_{3}$ [14-16]. After that, the masterbatch samples $(1 \mathrm{~mm} \times 2 \mathrm{~mm} \times 100 \mathrm{~mm}$ ) were placed into the body simulation fluid of "Hanks" solution, and they were put into a Thermostatic Water Bath ( $\mathrm{HH}-8$, Ningbo Textile Instrument Factory) at $37^{\circ} \mathrm{C}$ which simulated the human body temperature [17]. In the process of degradation test, the "Hanks" solution should be replaced regularly to simulate the body fluid circulation. The PLLA/PCL masterbatch samples will be degraded gradually in "Hanks" solution. After a certain amount of time, the samples were taken out and dried, and then the structure and properties were measured. 


\section{RESULTS AND DISCUSSION}

The surface morphology of PLLA/PCL masterbatch in degradation

In the process of degradation, the surface morphology of masterbatch in different proportions of PLLA/PCL will change, as shown in figure 1.

Figure 1, a-c, which are the masterbatchs in 90/10 proportion of PLLA/PCL, shows that the surface of masterbatch was etched more and more seriously with the time, even many large gullies were appeared on the surface of masterbatch (yellow arrows in figure 1,c. Figure 1, $d-f$, which are the masterbatchs in $90 / 10$ proportion of PLLA/PCL, shows that with the further degradation, the surface of masterbatch was etched more and more seriously and even appeared many potholes (red arrows in figure 1,e-f). Figure 1, $g-i$, which are the masterbatchs in $10 / 90$ proportion of PLLA/PCL, shows that the surface of masterbatch was etched slightly in degradation.

In addition, we compared these images in different proportions vertically, and found that the larger pro-
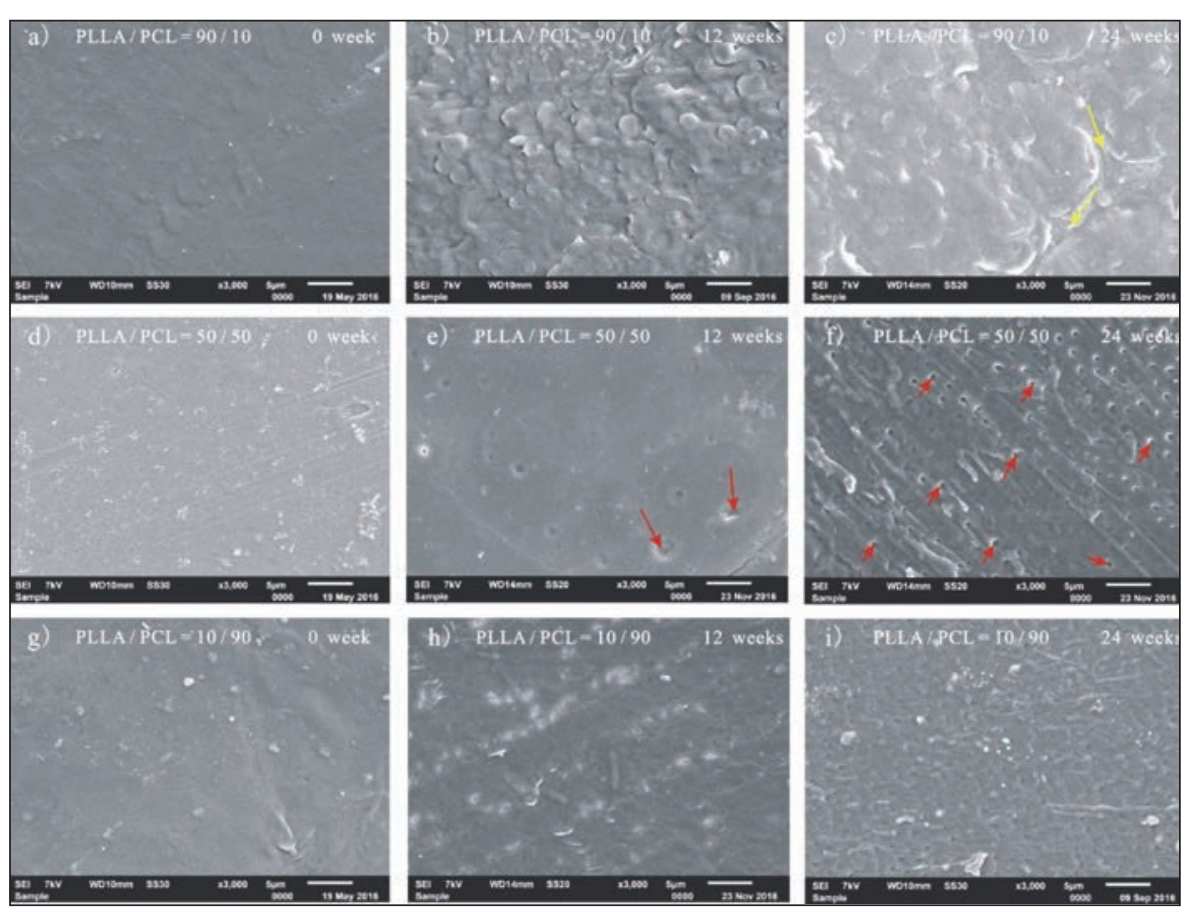

Fig. 1. The surface morphology of PLLA/PCL masterbatch



Fig. 2. FTIR of PLLA/PCL masterbatch with $70 / 30$ proportion in degradation portion of PLLA, the greater etching effect on surface of masterbatch, and the greater proportion of $\mathrm{PCL}$, the less etching effect on surface of masterbatch. This indicated that the degradation rate of PCL was slower than that of PLLA, and the more PCL in the masterbatch, the slower degradation rate and the longer degradation period of the masterbatch.

The chemical structure of PLLA/PCL masterbatch in degradation

The infrared spectra of masterbatch in degradation were shown in figure 2 hardly changed in the process of 20 weeks degradation, which shows that the group of " $-\mathrm{CH}_{2}-$ " was not broken down or degraded in the 20 weeks degradation. The results above suggested that the ester bonds, which exist in both PCL and PLLA molecules, were easily broken down by water and degraded firstly during the process of the degradation of PLLA/PCL masterbatch in vitro, but the groups of "- $\mathrm{CH}_{2}-$ " and others was stable and not easy to be degraded.

The crystallization of PLLA/PCL masterbatch in degradation

The XRD of masterbatch in different proportions of PLLA/ $P C L$ is shown in figure 3 .

Figure 3 shows that the characteristic diffraction peak of pure PLLA, in 100/0 proportion of PLLA/PCL, was located at $16.87^{\circ}$ and $19.19^{\circ}$, and the characteristic diffraction peak of pure $P C L$, in $0 / 100$ proportion of PLLA/PCL, was located at $21.76^{\circ}, 22.31^{\circ}$ and $23.96^{\circ}$. Through comparing all XRD patterns from $100 / 0$ to $0 / 100$ proportions of PLLA/ $P C L$, we found that with the increasing content of PCL and the decreasing content of PLLA, the characteristic diffraction peak of $\mathrm{PCL}$ at $21.76^{\circ}, 22.31^{\circ}$ and $23.96^{\circ}$ was bigger and bigger, on the contrary, the characteristic 


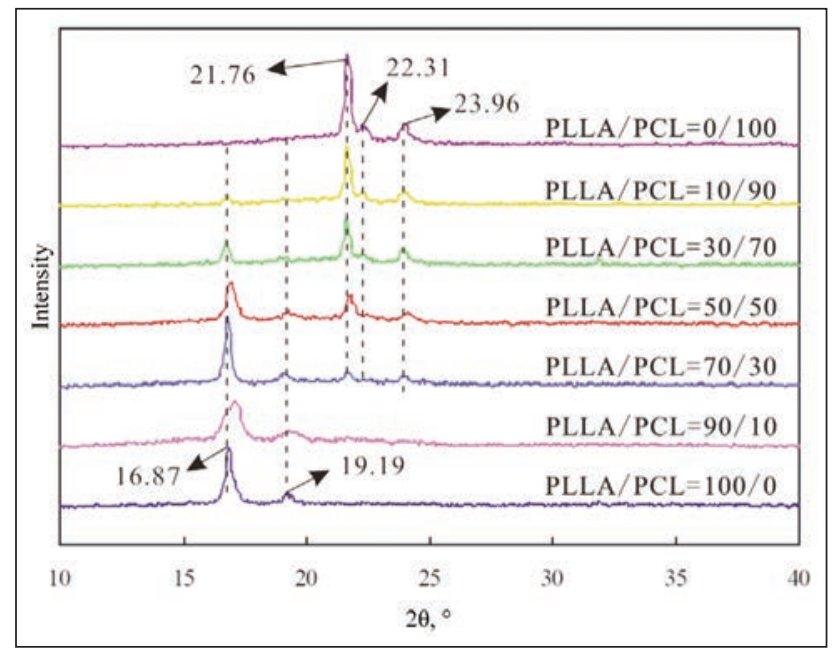

Fig. 3. XRD of PLLA/PCL masterbatchs in different proportions

diffraction peak of PLLA at $16.87^{\circ}$ and $19.19^{\circ}$ was smaller and smaller. The rule of peak variation was consistent with that of proportion of PLLA/PCL samples.

In the process of degradation, the crystallization of PLLA/PCL masterbatch would change, and the XRD patterns of PLLA/PCL masterbatch in degradation were shown in figure 4.

Figure 4 shows that the characteristic diffraction peaks of PLLA at $16.87^{\circ}$ and $19.19^{\circ}$, and the characteristic diffraction peaks of PCL at $21.76^{\circ}, 22.31^{\circ}$ and $23.96^{\circ}$, were weakened gradually as the masterbatch was degraded, which indicated that the crystalline region in PLLA/PCL masterbatch or the degree of crystallinity decreased gradually in the process of degradation. It was because that the ester bonds in molecular chains of PLLA and PCL masterbatch would be hydrolyzed by the water in the simulated body fluid, and the molecular chain was broken, so that the orderly arrangement of molecular chains in the crystalline regions was destroyed, and then the crystalline state was transformed into amorphous form, that was, non-crystalline state.

The mass loss rate of PLLA/PCL masterbatch in degradation

In process of degradation, the mass of PLLA/PCL masterbatch will lose, and the mass loss rate of masterbatch is shown in figure 5.

Figure 5 shows that with the time of degradation, the mass lose rate increased gradually. It is because that the macromolecules in PLLA/PCL masterbatch would break into micro-molecule, and then the micromolecules would further degrade into $\mathrm{CO}_{2}$ and $\mathrm{H}_{2} \mathrm{O}$, therefore the mass of masterbatch would lose, and the mass loss rate increased. It is also known from figure 5 that the larger proportion of PCL in the masterbatch, the lower mass loss rate of masterbatch in degradation. It is because that the degradation rate of PCL was slower than that of PLLA, which was proved in the above crystallization analysis in this paper. Hence, with the proportion of PCL increased in

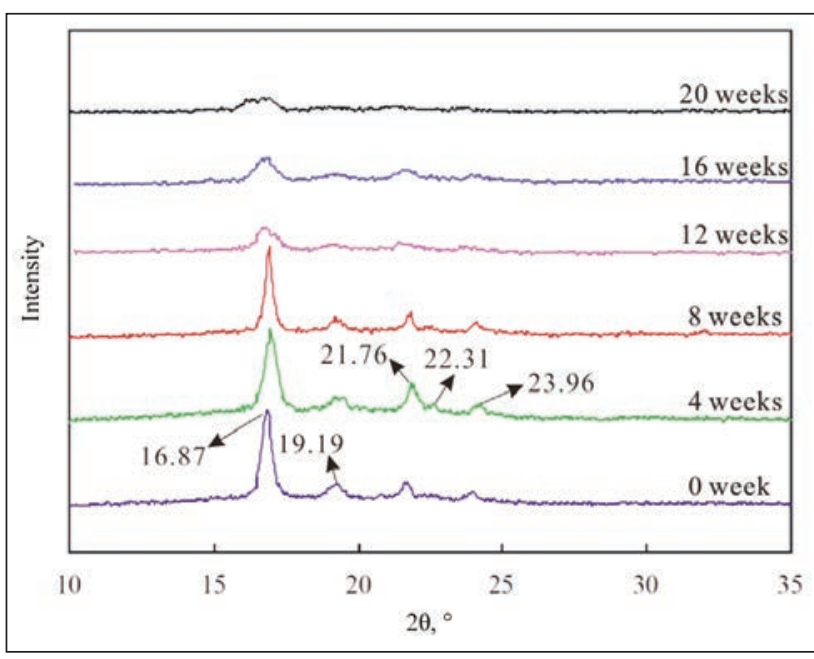

Fig. 4. XRD of 70/30 PLLA/PCL masterbatch in degradation

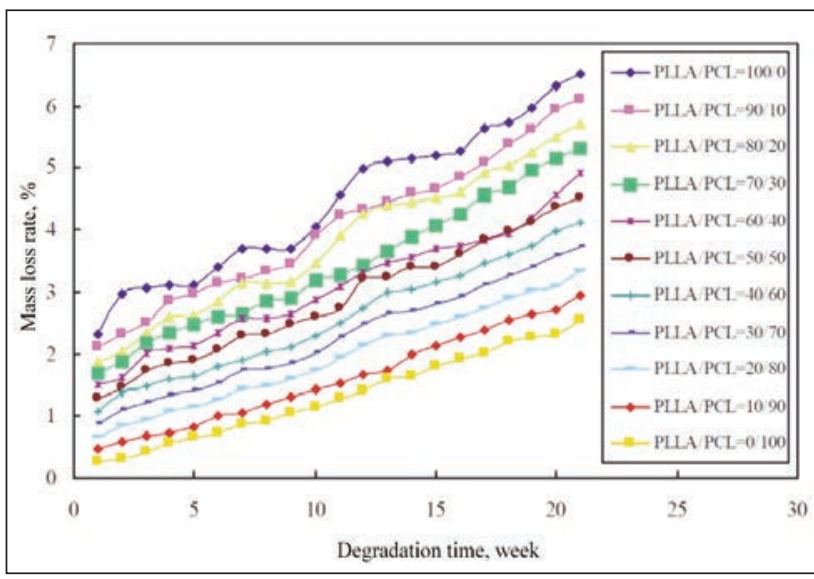

Fig. 5. Mass loss rate of PLLA/PCL masterbatchs in degradation

the masterbatch, the mass loss rate of masterbatch decreased.

The breaking strength of PLLA/PCL masterbatch in degradation

The mechanical properties of masterbatch will affect the mechanical properties of the textile medical products. So the breaking strength of masterbatch in process of degradation were investigated, as shown in figure 6 .

Before degradation (at 0 week), the breaking strength of pure $P C L$, at $1 / 100$ proportion of PLLA/PCL, is far lower than that of pure PLLA at $100 / 1$ proportion of PLLA/PCL, and with the increase of PCL in the masterbatch, the breaking strength of masterbatch decreased. This is because that PCL macromolecule was a linear molecule without branched chains and the interaction among molecules was small, so the molecules were easy to slip, which led to the poor strength and good toughness of PCL. Therefore, the more PCL involved in masterbatch, the lower breaking strength for the PLLA/PCL masterbatch.

Figure 6 also shows that with the time of degradation, the breaking strength of PLLA/PCL masterbatchs 


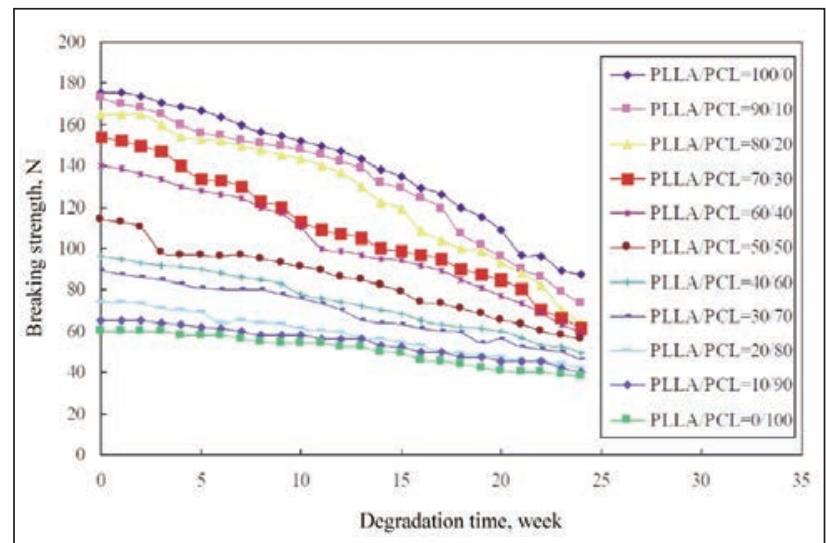

Fig. 6. Breaking strength of PLLA/PCL masterbatchs in degradation

declined rapidly, owing to the continuous degradation of masterbatchs. And it can be also known that with the proportion of $\mathrm{PCL}$ in masterbatch increased, the rate of decline of breaking strength, which could be expressed by the slope of tangent line, decreased. This is because that the PCL had a lower degradation rate relatively to PLLA, as the proportion of PCL increased in masterbatch, the degradation rate of masterbatch would slow down, thence the breaking strength would decline in a slower rate. In particular, the change rule of breaking strength was consistent with that of mass loss rate.

\section{CONCLUSION}

In this work, the surface of PLLA/PCL masterbatch was etched and degraded in the process of degradation, and the mixing ratio of PLLA and PCL influenced the degradation of masterbatch mainly. The larger proportion of PCL in masterbatch led to the less etching and slower degradation. In degradation, the ester bonds would be hydrolyzed firstly, and the crystallization region in PLLA/PCL masterbatch would be destroyed gradually to form a non-crystalline region. And the degradation rate of PLLA in masterbatch was faster than that of PCL. The mass of PLLA/PCL masterbatch decreased with the degradation, and with the proportion of PCL involved in masterbatch increased, the mass loss rate of masterbatch in degradation decreased. The more PCL involved in masterbatch, the lower breaking strength. With the degradation, the breaking strength of masterbatch declined rapidly, and with the proportion of $\mathrm{PCL}$ in masterbatch increased, the rate of decline of breaking strength decreased.

\section{ACKNOWLEDGEMENTS}

This work was supported by the MOE (Ministry of Education in China) Project of Humanities and Social Sciences (No. 18YJC760051), 2017 Shanxi Philosophy and Social Science Project (No. 201702), the Program for the Philosophy and Social Sciences Research of Higher Learning Institutions of Shanxi (PSSR) (No. 201803060), the Shanxi University Students Innovation and Entrepreneurship Training Program Project (No. 2018099), the Students Innovation and Entrepreneurship Training Program Project of Taiyuan University of Technology (No. 18049) and the Scientific and Technological Innovation Programs of Higher Education Institutions in Shanxi, China (No. 2015125).

\section{REFERENCES}

[1] Griffiths, S.Y., Jalava, J.V., A comprehensive neuroimaging review of PCL-R defined psychopathy. In: Aggression and Violent Behaviour, 2017, 36, 60-75

[2] Li, W., Jia, Y.J., Li, L.X., A two-scale approach to numerically predict the strength and degradation of composites. In: Applied Composite Materials, 2018, 25, 85-103

[3] Zhang, C., Cai X., Wang F., Preparation and evaluation of the self-cleaning poly (lactic acid) (PLA) film blended with Titanium dioxide $\left(\mathrm{TiO}_{2}\right.$ ) nano particles. In: Industria Textila, 2016, 67, 2, 121-126

[4] Surucu, S., Masur, K., Sasmazel, H.T., et al., Atmospheric plasma surface modifications of electrospun PCL/chitosan/PCL hybrid scaffolds by nozzle type plasma jets for usage of cell cultivation. In: Applied Surface Science, 2016, 385, 400-409

[5] Loiola, L.M.D., Más, B.A., Duek, E.A.R., et al., Amphiphilic multiblock copolymers of PLLA, PEO and PPO blocks: Synthesis, properties and cell affinity. In: European Polymer Journal, 2015, 68, 618-629

[6] Lu, Y., Chen, Y.C., Zhang, P.H., A membrane coated composite mesh for repairing pelvic floor defects using electrospinning method. In: Industria Textila, 2015, 66, 4, 192-199

[7] Scaffaro, R., Lopresti, F., Botta, L., Preparation, characterization and hydrolytic degradation of PLA/PCL co-mingled nanofibrous mats prepared via dual-jet electrospinning. In: European Polymer Journal, 2017, 96, 266-277

[8] Qian, W., Song, T., Ye, M., et al., PAA-g-PLA amphiphilic graft copolymer: synthesis, self-assembly, and drug loading ability. In: Polymer Chemistry, 2017, 8, 4098-4107

[9] Choi, K., Lim, S., Choi, M., et al., Properties of poly(ethylene glycol)-grafted poly(lactic acid) plasticized with poly(ethylene glycol). In: Macromolecular Research, 2014, 22, 1312-1319

[10] Han, D., Wen, T., Han, G., et al., Synthesis of Janus POSS star polymer and exploring its compatibilization behaviour for PLLA/PCL polymer blends. In: Polymer, 2018, 136, 84-91

[11] Peng, X., Zhang, Y., Chen, Y., et al., Synthesis and crystallization of well-defined biodegradable miktoarm star PEGPCL-PLLA copolymer. In: Materials Letters, 2016, 171, 83-86

[12] Lui, Y.S., Lewis, M.P., Loo, S.C.J., Sustained $\square$ release of naproxen sodium from electrospun-aligned PLLA-PCL scaffolds. In: Journal of Tissue Engineering and Regenerative Medicine, 2017, 11, 1011-1021 
[13] Mashhadikhan, M., Soleimani, M., Parivar, K., et al., ADSCs on PLLA/PCL hybrid nanoscaffold and gelatin modification: cytocompatibility and mechanical properties. In: Avicenna Journal of Medical Biotechnology, 2015, 7, 32-38

[14] Guerra, A.J., Ciurana, J., Effect of fibre laser process on in-vitro degradation rate of a polycaprolactone stent a novel degradation study method. In: Polymer Degradation and Stability, 2017, 142, 42-49

[15] Yang, X., Cao, F., Qing, W., et al., The degradation behaviour of $\mathrm{SiC}_{f} / \mathrm{SiO}_{2}$ composites in high-temperature environment. In: Applied Composite Materials, 2018, 25, 353-364

[16] Subtirica, A.I., Banciu, C.A., Chivu, A.A.-M., Dinca, L.C., Nanofibres made from biocompatible and biodegradable polymers, with potential application as medical textiles, In: Industria Textila, 2018, 69, 1, 55-58, http://doi.org/ 10.35530/IT.069.01.1502

[17] Yanhui, L., Ruitao, J., Mian, W., Shaoju, F., Peihua, Z., Degradation and biocompatibility behaviors of fully covered biodegradable polydioxanone biliary stent for human body, In: Industria Textila, 2019, 70, 5, 393-397, http://doi.org/ 10.35530/IT.070.05.1344

Authors:

SHU-QIANG LIU1,2, KAI-WEN WANG ${ }^{1}$, YA-RU YANG ${ }^{3}$, HUI-MIN LI' ${ }^{1}$, GAI-HONG WU11, JUAN-JUAN YU ${ }^{1}$, MING-FANG LIU ${ }^{1}$, YAO ZHANG ${ }^{1}$, PENG WANG ${ }^{1}$, JIE ZHANG ${ }^{1}$, AN XU ${ }^{1}$, XIAO-LONG YIN ${ }^{1}$, FU LI ${ }^{1}$, MAN ZHANG ${ }^{1}$

${ }^{1}$ College of Textile Engineering, Taiyuan University of Technology, 030024, Taiyuan, China

${ }^{2}$ Textile Engineering Institute, Taiyuan University of Technology, 030024, Taiyuan, China

${ }^{3}$ College of Materials and Textile Engineering, Jiaxing University, 314001, Jiaxing, China

Corresponding authors:

SHU-QIANG LIU

e-mail: liushuqiang8866@126.com

GAI-HONG WU

e-mail: gaigai2003@126.com 


\title{
Comparison of sewn fabric bending rigidities obtained by heart loop method: effects of different stitch types and seam directions
}

\author{
DOI: $10.35530 / \mathrm{IT} .071 .02 .1647$
}

\section{ABSTRACT - REZUMAT}

\section{Comparison of sewn fabric bending rigidities: effects of different stitch types and seam directions}

Sewing quality is an important factor that contributes to the overall quality of an end-product. Sewing quality compromises different components such as bending, seam strength, seam slippage, elasticity etc. Among these components, bending has a special importance because of causing changes in appearance, sensorial comfort and drape of a garment. Therefore, in this study, effects of stitch type and seam direction on the bending rigidities of sewn fabrics were evaluated and compared. A polyester woven fabric which is suitable for sportswear was sewn with three basic stitch types (lock stitch, chain stitch and overlock stitch), in 5 different directions (warp, weft, $30^{\circ}, 45^{\circ}$ and $60^{\circ}$ angles). As reference, samples without stitches were tested, too. Bending properties of samples were determined via heart loop method. According to the results, sewing increased the fabric bending rigidity. The degree of bending rigidity increment was dependent on the stitch type. Highest bending rigidity values were obtained for overlock stitched samples those were approximately 4 times higher when compared to non-sewn reference samples. Thickness of sewn parts was in accordance with the bending rigidity results. For oriented seams, bias sewing especially for $45^{\circ}$ oriented samples, showed the most advantageous bending results. This study showed the usability of heart loop method for sewn samples via consistent results for different stitch types and seam directions.

Keywords: bending rigidity, heart loop method, sewn fabrics, stitch type, seam direction.

Analiza comparativă a rigidității la încovoire a asamblărilor prin coasere: influența diferitelor tipuri de cusături și a direcțiilor de coasere

Calitatea asamblărilor prin coasere este un factor important care contribuie la calitatea generală a unui produs final. Calitatea asamblărilor prin coasere influențază diferite caracteristici, cum ar fi rezistența la încovoiere, rezistența cusăturii, elasticitatea etc. Printre aceste caracteristici, rezistența la încovoiere are o importanță deosebită deoarece influențează aspectul, confortul senzorial și drapajul unui produs de îmbrăcăminte. Astfel, în acest studiu, a fost evaluată și comparată influența tipului de cusătură și direcției de coasere asupra rigidității la încovoiere a materialelor textile asamblate. O țesătură din poliester care este destinată articolelor de îmbrăcăminte sport a fost asamblată cu trei tipuri de cusături de bază (cusătură simplă, cusătură lanț și cusătură de surfilare), în 5 direcții diferite (urzeală, bătătură, diagonal cu unghiuri de $30^{\circ}, 45^{\circ}$ și $60^{\circ}$ ). Ca referință, au fost testate și probe fără cusături. Rezistență la încovoiere a probelor a fost determinată prin metoda în buclă. Conform rezultatelor, asamblarea prin coasere determină creșterea rigidității la încovoiere a țesăturii. Gradul de rigiditate la încovoiere depinde de tipul de cusătură. Valorile cele mai ridicate ale rigidității la încovoiere au fost obținute pentru probele asamblate prin cusătură de surfilare, acestea fiind de aproximativ 4 ori mai mari în comparație cu probele de referință necusute. Grosimea pieselor asamblate a fost influențată similar cu rigiditatea la încovoiere. Cusăturile diagonale, în special pentru probele orientate la $45^{\circ}$, au prezentat cele mai mici valori pentru rezistența la încovoiere. Acest studiu a demonstrat utilizarea metodei în buclă pentru probele asamblate, prin rezultate importante pentru diferite tipuri de cusături și direcții de coasere.

Cuvinte-cheie: rigiditate la încovoiere, metoda în buclă, ţesături asamblate, tip de cusătură, direcţia de coasere

\section{INTRODUCTION}

Ready-to-wear end-products are obtained by sewing (stitching), bonding, welding or pressing the fabrics which were cut in certain dimensions and shapes [1]. Among the ready-to-wear assembling methods, stitching with a sewing thread is the most common and will have a continuing importance in the following decades.
Esthetical and in-use quality of a garment is mostly determined by the fabric quality. In addition, sewing quality is also an important factor that affects both the esthetic and functional properties of the end-product [2]. Sewing quality is related to seam appearance and seam performance that have the components such as seam strength, seam slippage, seam elasticity and recovery, seam puckering, softness, drape and resistance to abrasion $[1,3]$. In the literature 
effects of stitch density, seam direction, sewing thread properties, sewing thread tensions, sewing needle fineness, fabric type, washing etc. on the seam strength and seam slippage were studied, widely [4-19]. On the other hand, bending rigidity is another important factor that affects both the drape and form of the sewn fabrics. In the literature, there are some studies that evaluated the effects of stitch density [20-21], sewing thread type, sewing needle fineness [5], sewing thread tension [5], seam allowance [21-23], seam placement [23], seam direction (warp, weft, $45^{\circ}$ bias) [24], fabric thickness [22] and fabric type [20, 23] on the bending rigidity and drape of the sewn seams. As known, there are a variety of stitch types which can be preferred according to the fabric type, purpose of usage and end-use area. According to the knowledge of author, there is not any study focusing on the bending rigidities of fabrics sewn with different stitch types.

Generally, properties of sewn fabrics are tested in warp and weft directions. In spite of this, in real garment production, fabric pieces are frequently sewn together with different angles to warp or weft directions, as shown in figure 1.
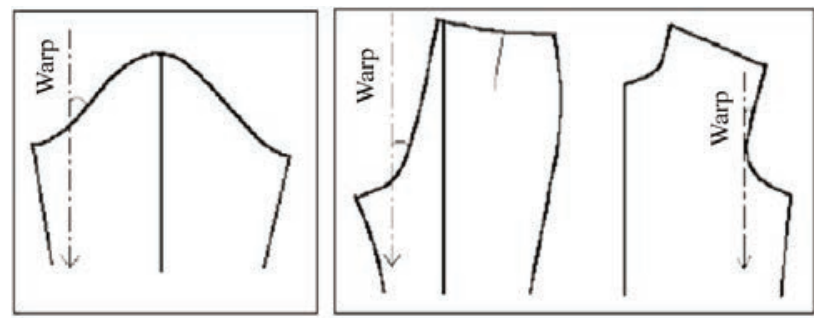

Fig. 1. Oriented seam lines in different garment pieces [9]

Straight or curved seams can be formed in yokes, darts, side seams, shoulders or armpits in different directions for several garment models. Bending rigidities in these oriented seams may change and impair the seam appearances by affecting the drape. Therefore, in this study, seams at different directions were formed and effect of seam direction on the bending rigidities of sewn fabrics was evaluated, too. By this way, the interaction of both seam direction and stitch type on the bending rigidity of sewn fabrics were evaluated. Also, different than the literature, sewn fabric bending rigidities were determined by heart loop method. Sewn samples form multilayer structures along the seam lines, which contain 3 fabric layers with the seam allowances. In addition, some curviness are formed on the short edges of samples because of the seams. These - curviness on the short edge and multilayered structure of test samples - may cause some mistakes during the readings of cantilever stiffness test. It is known that heart loop method can be used for the samples, which are not appropriate to cantilever test. In this study, to avoid from possible mistakes, heart loop method was applied for bending rigidity measurements of sewn samples instead of cantilever test.
Overall, the aim of this study was to determine the bending rigidities of sewn woven fabrics by heart loop method and compare the results in terms of stitch types and seam directions. For this purpose; lock stitch (stitch type 301, 2 yarn), chain stitch (stitch type 401, 2 yarn) and overlock stitch (stitch type 504, 3 yarn) were selected as they are the most used stitch types. These three stitches were sewn in 5 different directions; namely, warp weft, $30^{\circ}, 45^{\circ}$ and $60^{\circ}$ angles with weft direction. As the seam appearances and seam allowances in face and back of the fabric are different, bending rigidities of samples were determined for both face and back of the fabric and the mean bending rigidities for each sample type were calculated.

\section{MATERIALS AND METHODS}

\section{Materials}

Materials of this study are consisted of woven polyester fabric and polyester sewing thread. Woven fabric properties are given in table 1. Sewing thread is a Serafil fine (Amann Group) 100\% polyester sewing thread with ticket number 120.

\begin{tabular}{|l|c|}
\hline \multicolumn{2}{|c|}{ PROPERTIES OF POLYESTER FABRIC } \\
\hline Raw material & $\begin{array}{c}100 \% \text { polyester } \\
\text { multifilament yarn }\end{array}$ \\
\hline Woven fabric type & Plain weave \\
\hline Unit mass $\left(\mathrm{g} / \mathrm{m}^{2}\right)$ & 79.8 \\
\hline Thickness $(\mathrm{mm})$ & 0.15 \\
\hline Weft density (threads/cm) & 47 \\
\hline Warp density (threads/cm) & 76 \\
\hline
\end{tabular}

\section{Methods}

\section{Sample preparation}

For all seam directions and stitch types, stitch density was fixed at 5 stitches/cm and seam allowances were kept as $5 \mathrm{~mm}$. After sewing, all the seams were folded and ironed as shown in the back views in figure 2.

Samples were sewn with 3 main stitch types namely; lock stitch, chain stitch and overlock stitch. To make comparisons, reference fabrics with no seams were tested for their bending properties, too. All the samples were sewn with straight seams in 5 directions. These directions were consisted of warp, weft, $30^{\circ}$, $45^{\circ}$ and $60^{\circ}$ angles with weft direction. The experimental plan of the study is given in figure 3 . Sample dimensions were selected as $2.5 \mathrm{~cm} \times 25 \mathrm{~cm}$ according to standard. In order to eliminate the tension differences which may occur on the starting and finishing ends of the sewn samples, samples were prepared $10 \mathrm{~cm}$ longer than the last dimensions and cut from each ends before testing. Seams were placed in the middle of the samples along the longer edges. 




Fig. 2. Face and back side appearances of sewn samples

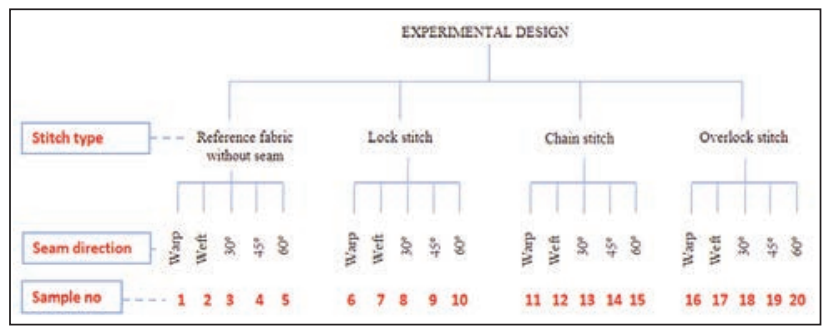

Fig. 3. Experimental plan and sample codes

All the samples were conditioned before testing at standard atmosphere conditions $\left(20 \pm 2^{\circ} \mathrm{C}, 65 \pm 5 \%\right.$ relative humidity) for 24 hours after ironing.

\section{Determination of the sample thicknesses}

Thickness of samples' sewn parts were determined according to TS 7128 EN ISO 5084 [25] standard by using James Heal RxB Cloth Thickness Tester. The pressure during measurements was $5 \mathrm{gf} / \mathrm{cm}^{2} .5$ measurements were taken for each stitch type and average values were calculated.

\section{Determination of the bending rigidities - Heart loop method}

Heart loop method is based on calculating the bending rigidity of a fabric strip which is formed to a heartshaped loop and hung vertically under its own mass. The length of the hung loop is measured and bending length and bending rigidity of the samples are calculated via this measurement (ASTM D 1388-14 [26]). Application of the heart loop method is harder than the cantilever method. But, heart loop method is preferred for the samples which are unsuitable for cantilever method, which tend to curl or twist.

As the sewn fabrics have a plied structure along the seam line, cantilever method may cause mistakes during determining the bending length. Therefore, bending rigidities of samples were determined according to ASTM D 1388-14 standard Option B - Heart Loop Method, in this study. Samples were fixed at two bars as shown in figure 4 in order to form a heart shaped loop. Test dimensions were $2.5 \mathrm{~cm} \times 20 \mathrm{~cm}$ because of the fastening of samples to the $2.5 \mathrm{~cm}$ wide bars.

Two measurements were performed for each sample. Firstly, the back face of the sample was in the outer side of the loop during the measurement. For the second measurement of the sample, face side of the sample was in the outer side of the loop. The obtained loop lengths were used to calculate the bending rigidities according to equation 1 . Bending length (c), $f_{2}(\theta)$ and $\theta$ were calculated according to equations 2, 3 and 4, respectively [27]. For each stitch type and seam direction, 4 samples were measured according to standard.

Fig. 4. Heart loop test apparatus and sample placement

Bending rigidity:

$$
G=1.421 \cdot 10^{-5} \cdot w \cdot c^{3}
$$

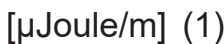$$
c=0.1337 \mathrm{~L} \cdot f_{2}(\theta)[\mathrm{cm}]
$$$$
f_{2}(\theta)=(\cos \theta / \tan \theta)^{1 / 3}
$$$$
\theta=32.85 \cdot[(I-0.1337 \mathrm{~L}) /(0.1337 \mathrm{~L})]\left[{ }^{\circ}\right]
$$

$L$ is strip length $(\mathrm{cm}), w-$ unit mass $\left(\mathrm{g} / \mathrm{m}^{2}\right)$ and $I-$ loop length $(\mathrm{cm})$.

\section{RESULTS}

\section{Thickness results}

Samples were consisted of fabrics sewn with lock stitch, chain stitch and overlock stitch. Also reference samples without stitches were measured, too. In the sewn places, an additional thickness was occurred 
because of sewing threads and folded fabrics. These thickness increments might contribute to bending rigidity changes of the sewn samples.

Mean thickness values and standard deviations of samples are given in table 2. Also, samples' thickness values are shown graphically in figure 5 .

Table 2

THICKNESS OF SEWN PARTS OF SAMPLES AND REFERENCE FABRIC

\begin{tabular}{|c|c|c|}
\hline Sample & $\begin{array}{c}\text { Mean } \\
(\mathbf{m m})\end{array}$ & $\begin{array}{c}\text { Standard deviation } \\
(\mathbf{m m})\end{array}$ \\
\hline $\begin{array}{c}\text { Reference fabric } \\
\text { (without seam) }\end{array}$ & 0.15 & 0.008944 \\
\hline Lock Stitch & 0.65 & 0.040415 \\
\hline Chain Stitch & 0.81 & 0.017321 \\
\hline Overlock Stitch & 1.02 & 0.093229 \\
\hline
\end{tabular}

According to test results given in table 2, thickness of sewn parts of samples increased 4 to 7 times when compared to reference fabric. Thickness of reference fabric was $0.15 \mathrm{~mm}$ while thickness of lock stitched, chain stitched and overlock stitched samples were $0.65,0.81$ and $1.02 \mathrm{~mm}$, respectively. The overlock stitch with the highest number of sewing threads which covered $5 \mathrm{~mm}$ seam allowance, had higher thickness when compared to lock stitch and chain stitch.

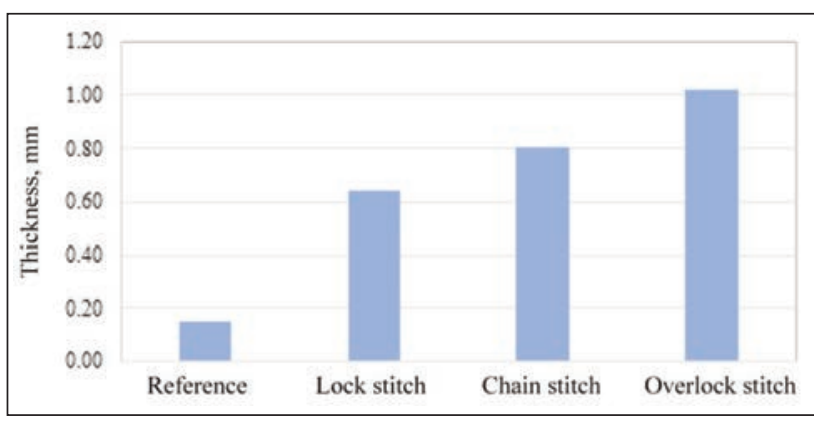

Fig. 5. Thickness values of samples

\section{Bending rigidity and bending length results}

Bending length of samples are given in table 3 and figure 6 , with respect to the face side, back side and the mean of the two sides. Bending rigidities of face and back sides of the samples represent the behavior of bent garment from the outer and inner faces.

Bending lengths were between $1.18-2.10 \mathrm{~cm}$ for the face of samples and 1.13-2.20 cm for the back of samples. In general, bending lengths calculated for face and back sides of samples were very close to each other. When the mean values were calculated for each sample by using the results of face and back sides, the bending lengths were obtained between 1.16 and $2.15 \mathrm{~cm}$ for all samples. The bending lengths were the lowest for reference samples and highest for the samples sewn with overlock stitch

Table 3

BENDING LENGTH RESULTS OF SAMPLES BELONGING TO FACE AND BACK SIDES AND MEAN VALUES

\begin{tabular}{|c|c|c|c|c|c|c|c|}
\hline \multirow{3}{*}{\multicolumn{2}{|c|}{ Sample }} & \multicolumn{6}{|c|}{ Bending length (cm) } \\
\hline & & \multicolumn{2}{|c|}{ FACE SIDE } & \multicolumn{2}{|c|}{ BACK SIDE } & \multicolumn{2}{|c|}{ MEAN } \\
\hline & & Mean & St. Dev. & Mean & St. Dev. & Mean & St. Dev. \\
\hline \multirow{5}{*}{ Reference fabric } & Warp & 1.39 & 0.03 & 1.42 & 0.05 & 1.40 & 0.04 \\
\hline & Weft & 1.33 & 0.05 & 1.35 & 0.03 & 1.34 & 0.04 \\
\hline & $30^{\circ}$ & 1.19 & 0.11 & 1.13 & 0.06 & 1.16 & 0.09 \\
\hline & $45^{\circ}$ & 1.18 & 0.06 & 1.21 & 0.00 & 1.19 & 0.04 \\
\hline & $60^{\circ}$ & 1.19 & 0.06 & 1.22 & 0.03 & 1.20 & 0.04 \\
\hline \multirow{5}{*}{ Lock stitch } & Warp & 1.92 & 0.13 & 1.91 & 0.12 & 1.92 & 0.12 \\
\hline & Weft & 1.89 & 0.11 & 1.80 & 0.15 & 1.84 & 0.13 \\
\hline & $30^{\circ}$ & 1.81 & 0.08 & 1.75 & 0.09 & 1.78 & 0.09 \\
\hline & $45^{\circ}$ & 1.59 & 0.11 & 1.51 & 0.03 & 1.55 & 0.09 \\
\hline & $60^{\circ}$ & 1.66 & 0.03 & 1.60 & 0.03 & 1.63 & 0.04 \\
\hline \multirow{5}{*}{ Chain stitch } & Warp & 2.02 & 0.10 & 2.06 & 0.12 & 2.04 & 0.10 \\
\hline & Weft & 1.99 & 0.14 & 2.04 & 0.10 & 2.01 & 0.12 \\
\hline & $30^{\circ}$ & 1.90 & 0.09 & 1.85 & 0.07 & 1.87 & 0.08 \\
\hline & $45^{\circ}$ & 1.58 & 0.05 & 1.51 & 0.15 & 1.54 & 0.11 \\
\hline & $60^{\circ}$ & 1.72 & 0.09 & 1.71 & 0.05 & 1.71 & 0.07 \\
\hline \multirow{5}{*}{ Overlock stitch } & Warp & 2.10 & 0.07 & 2.20 & 0.07 & 2.15 & 0.10 \\
\hline & Weft & 2.05 & 0.11 & 2.04 & 0.06 & 2.04 & 0.12 \\
\hline & $30^{\circ}$ & 1.82 & 0.07 & 1.69 & 0.11 & 1.76 & 0.08 \\
\hline & $45^{\circ}$ & 1.67 & 0.03 & 1.51 & 0.03 & 1.59 & 0.11 \\
\hline & $60^{\circ}$ & 1.71 & 0.06 & 1.71 & 0.05 & 1.71 & 0.07 \\
\hline
\end{tabular}




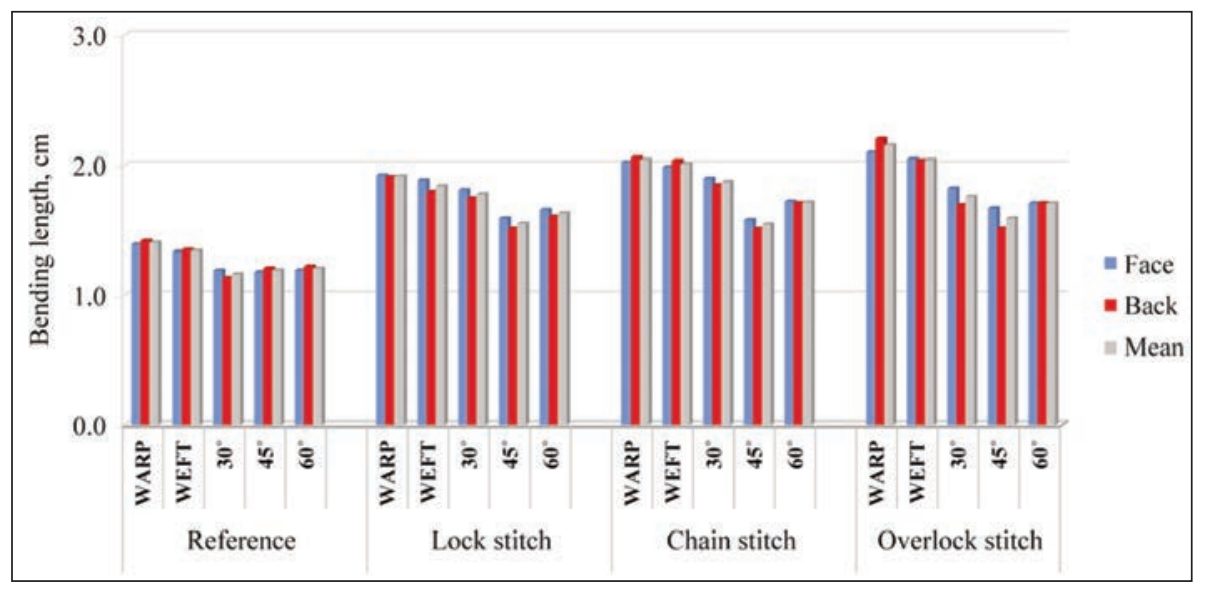

Fig. 6. Bending lengths of samples
The mean bending rigidities of all samples were between 1.80 and $11.30 \mu \mathrm{J} / \mathrm{m}$. The lowest bending rigidities were obtained for reference samples without sewing and this is valid for all testing directions (warp, weft, $30^{\circ}$, $45^{\circ}$ and $60^{\circ}$ ). For sewn samples, bending rigidity values were 2.2 to 4.2 times higher when compared to reference samples. As for the thickness results, the highest bending rigidities were obtained for overlock stitched samples and they were followed by type. Highest bending lengths were obtained for the samples in warp direction while lowest values were obtained for the samples sewn in $45^{\circ}$ direction.

Bending rigidities of samples are given in table 4 . Bending rigidities of samples were 1.85-10.51 $\mu \mathrm{J} / \mathrm{m}$ for face of the samples and 1.65-12.08 $\mu \mathrm{J} / \mathrm{m}$ for the back sides of the samples. As third power of the bending length (equation 1) was used to calculate the bending rigidity values, the differences between the face and back sides of the samples were more prominent for bending rigidities when compared to bending lengths. the chain stitched and lock stitched samples for all directions. The increment of bending rigidities dependent on the stitch type was higher for the samples sewn in $30^{\circ}$ direction.

Bending rigidity differences with respect to seam direction were obtained similar for all stitch types (lock, chain, overlock). For both reference samples and sewn samples, highest bending rigidity results were obtained in warp direction and they were followed by the weft direction. For the bias sewing, the lowest bending rigidity values were obtained for the samples sewn in $45^{\circ}$ direction. The samples sewn in

Table 4

BENDING RIGIDITY RESULTS OF SAMPLES BELONGING TO FACE AND BACK SIDES AND MEAN VALUES

\begin{tabular}{|c|c|c|c|c|c|c|c|}
\hline \multirow{3}{*}{ Sampl } & & \multicolumn{6}{|c|}{ Bending rigidity $(\mu \mathrm{J} / \mathrm{m})$} \\
\hline & & \multicolumn{2}{|c|}{ FACE SIDE } & \multicolumn{2}{|c|}{ BACK SIDE } & \multicolumn{2}{|c|}{ MEAN } \\
\hline & & Mean & St. Dev. & Mean & St. Dev. & Mean & St. Dev. \\
\hline \multirow{5}{*}{ Reference fabric } & Warp & 3.04 & 0.18 & 3.23 & 0.36 & 3.14 & 0.28 \\
\hline & Weft & 2.70 & 0.32 & 2.78 & 0.20 & 2.74 & 0.25 \\
\hline & $30^{\circ}$ & 1.94 & 0.50 & 1.65 & 0.25 & 1.80 & 0.40 \\
\hline & $45^{\circ}$ & 1.85 & 0.27 & 1.98 & 0.00 & 1.92 & 0.19 \\
\hline & $60^{\circ}$ & 1.92 & 0.27 & 2.06 & 0.15 & 1.99 & 0.22 \\
\hline \multirow{5}{*}{ Lock stitch } & Warp & 8.15 & 1.63 & 7.97 & 1.43 & 8.06 & 1.42 \\
\hline & Weft & 7.66 & 1.34 & 6.67 & 1.65 & 7.16 & 1.49 \\
\hline & $30^{\circ}$ & 6.74 & 0.82 & 6.07 & 0.97 & 6.41 & 0.91 \\
\hline & $45^{\circ}$ & 4.61 & 1.01 & 3.91 & 0.24 & 4.26 & 0.78 \\
\hline & $60^{\circ}$ & 5.15 & 0.25 & 4.68 & 0.23 & 4.91 & 0.34 \\
\hline \multirow{5}{*}{ Chain stitch } & Warp & 9.44 & 1.36 & 10.00 & 1.66 & 9.72 & 1.44 \\
\hline & Weft & 8.98 & 1.88 & 9.62 & 1.43 & 9.30 & 1.59 \\
\hline & $30^{\circ}$ & 7.79 & 1.13 & 7.17 & 0.85 & 7.48 & 0.98 \\
\hline & $45^{\circ}$ & 4.46 & 0.43 & 3.99 & 1.20 & 4.22 & 0.87 \\
\hline & $60^{\circ}$ & 5.80 & 0.90 & 5.65 & 0.48 & 5.73 & 0.67 \\
\hline \multirow{5}{*}{ Overlock stitch } & Warp & 10.51 & 1.09 & 12.08 & 1.14 & 11.30 & 1.33 \\
\hline & Weft & 9.81 & 1.60 & 9.59 & 0.87 & 9.70 & 1.20 \\
\hline & $30^{\circ}$ & 6.88 & 0.74 & 5.56 & 1.05 & 6.22 & 1.10 \\
\hline & $45^{\circ}$ & 5.27 & 0.28 & 3.91 & 0.24 & 4.59 & 0.76 \\
\hline & $60^{\circ}$ & 5.66 & 0.65 & 5.65 & 0.48 & 5.66 & 0.53 \\
\hline
\end{tabular}






Fig. 7. Bending rigidities of samples followed by the chain stitched and lock stitched samples. From the literature, it is known that chain and overlock stitches are more flexible stitch types than lock stitch $[1,3]$. These contrary results in bending rigidity may be related to sewn places' thicknesses. Bending rigidity results was in accordance with the thickness results, in this study. The higher the sewn sample thickness, the higher the bending rigidity was obtained from the samples.

The orientation of the seams

$30^{\circ}$ angle had higher bending rigidities when compared to samples sewn in $60^{\circ}$ angle. The bending rigidity differences for different directions may be related to crimp ratios and the mechanical properties of the warp and the weft yarns [28].

\section{DISCUSSION}

In this study, thickness and bending rigidities of sewn samples were determined and results were compared with respect to stitch type and seam direction. At all, 3 different stitch types (lock, chain and overlock stitches) and 5 different seam directions (warp, weft, $30^{\circ}, 45^{\circ}$ and $60^{\circ}$ ) were formed and 20 different samples were obtained including reference samples. Bending rigidities of samples were determined via heart loop method as an alternative to cantilever method.

According to results, sewing increased the fabric bending rigidity for all stitch types and seam directions. Among the sewn samples, bending rigidity was the highest for overlock stitched samples and it was affected the bending properties. Seams in bias directions exhibited lower bending rigidity results. This indicates that, bias sewing may help to improve the appearance, drape and mobility comfort of an endproduct by lowering the bending rigidity.

In this study, bending rigidity values were calculated for both face and back sides of the samples, individually. Then the mean bending rigidities were calculated for each sample type. According to the results, bending length and bending rigidity values were very close to each other for the 2 sides. The order of the bending rigidity values did not change with respect to face or back of the samples.

Overall, this study helps to understand how the bending behaviors of sewn samples change with respect to different stitches and seam directions. Also, the usability of heart loop method is shown by consistent results of systematically produced samples. This study is limited by the base fabric which is a very thin woven fabric suitable for sportswear. The study may be extended by using thicker fabrics and sewing thread types for other application areas.

\section{REFERENCES}

[1] Kurumer, G., Konfeksiyon uretimi ve teknolojisi (2 $2^{\text {nd }}$ Press), Izmir: Printer Ofset Matbaacılık, 2012

[2] Okur, A., Tekstil materyallerinde mukavemet testleri, Izmir: DEU Muhendislik Fakultesi Yayınları, 2002

[3] Jones, I., Stylios, G.K. (Eds.), Joining textiles: Principles and applications, Elsevier, 2013

[4] Namiranian, R., Shaikhzadeh Najar, S., Etrati, S.M., Manich, A.M., Seam slippage and seam strength behavior of elastic woven fabrics under static loading, In: Indian Journal of Fibre \& Textile Research (IJFTR), 2014, 39, 3, 221-229

[5] Choudhary, A.K., Goel, A., Effect of some fabric and sewing conditions on apparel seam characteristics, In: Journal of Textiles, 2013, 2013, 1-7

[6] Gurarda, A., Investigation of the seam performance of PET/nylon-elastane woven fabrics, In: Textile Research Journal, 2008, 78, 1, 21-27

[7] Bharani, M., Shiyamaladevi, P.S.S., Mahendra Gowda, R.V., Characterization of seam strength and seam slippage on cotton fabric with woven structures and finish, In: Research Journal of Engineering Sciences, 2012, 1, 2, 41-50

[8] Sular, V., Mesegul, C., Kefsiz, H., Seki, Y., A comparative study on seam performance of cotton and polyester woven fabrics, In: The Journal of the Textile Institute, 2015, 106, 1, 19-30

[9] Citoglu, F., Kaya, G., Dikis iplik ozelliklerinin ve dikis sıkliklarinin farklı dikis acilarında dikis mukavemeti uzerine etkileri, In: Tekstil ve Konfeksiyon, 2011, 21, 2, 182-188

[10] Xin, L.U., Effect of sewing form and parameters on seam strength of silk fabric, In: Shanghai Textile Science \& Technology, 2010, 5, 17

industroia textillă 
[11] Ozdemir, H, Yavuzkasap, D., The effects of yarn and fabric structural parameters on the seam slippage, abrasion and pilling properties of double woven upholstery fabrics, In: Industria Textila, 2012, 63, 6, 307-314

[12] Yesilpinar, S., Bahar, S., The effect of sewing and washing processes on the seam strength of denim trousers, In: AATCC review, 2007, 7, 10, 27-31

[13] Yeşilpınar, S., Analysis of the performance of sewing threads manufactured from conventional and compact ringspun yarns, In: Fibres \& Textiles in Eastern Europe, 2006, 14, 2, 20-23

[14] Gribaa, S., Ben Amar, S., Dogui, A., Influence of sewing parameters upon the tensile behavior of textile assembly, In: International journal of clothing science and Technology, 2006, 18, 4, 235-246

[15] Chowdhary, U., Poynor, D., Impact of stitch density on seam strength, seam elongation, and seam efficiency, In: International Journal of Consumer Studies, 2006, 30, 6, 561-568

[16] Tarafder, N., Karmakar, R., Mondal, M., The effect of stitch density on seam performance of garments stitched from plain and twill fabrics, In: Man-Made Textiles in India, 2007, 50, 8, 298-302

[17] Mukhopadhyay, A., Sikka, M., Karmakar, A.K., Impact of laundering on the seam tensile properties of suiting fabric, In: International Journal of Clothing Science and Technology, 2004, 16, 4, 394-403

[18] Brain, D.H., The prediction of strengths of lock stitch seams in woven fabrics, In: Journal of the Textile Institute, 1970, 61, 10, 493-505

[19] Günaydin, G.K., Effect of coating ratio and weft density on some physical properties of upholstery fabrics, In: Industria Textila, 2019, 70, 4, 379-385, http://doi.org/10.35530/IT.070.04.1695

[20] Megeid, Z.A., Ezzat, M.M., Elzaki, G.M., Studying the bending stiffness of polyester/linen fabric seams with different structures, In: International Journal of ChemTech Research, 2016, 9, 4, 1-6

[21] Gurarda, A., Dikiş parametrelerinin dokuma kumaşların eğilme dayanımı üzerine etkileri, In: Tekstil ve Konfeksiyon, 2009, 19, 3, 242-247

[22] Hu, J., Chung, S., Bending behavior of woven fabrics with vertical seams, In: Textile Research Journal, 2000, 70, 2, 148-153

[23] Chung, S., Hu, J., Lo, M., Effect of seam allowance of a plain seam on bending of woven fabrics, In: Research Journal of Textile and Apparel, 1999, 3, 1, 54-64

[24] Mahar, T.J., Ajiki, I., Postle, R., Fabric mechanical and physical properties relevant to clothing manufacture - Part 2: Structural balance, breaking elongation and curvature of seams, In: International Journal of Clothing Science and Technology, 1989, 1, 2, 5-10

[25] TS 7128 EN ISO 5084 Tekstil-Tekstil ve tekstil mamullerinin kalinlik tayini. Ankara: Turk Standartları Enstitusu, 1998

[26] ASTM D1388 Standard test method for stiffness of fabrics. Option B, Heart loop test. West Conshohocken: ASTM International, 2018

[27] Hu, J., Structure and mechanics of woven fabrics. Cambridge: Woodhead Publishing, 2004

[28] Gupta, B.S., Leek, F.J., Barker, R.L., Buchanan, D.R., Little, T.J., Directional variations in fabric properties and seam quality, In: International Journal of Clothing Science and Technology, 1992, 4, 2/3, 71-78

Author:

KARA SUKRAN

Dokuz Eylul University, Engineering Faculty, Textile Engineering Department, Tınaztepe Campus, Buca, 35397, Izmir, Turkey

Corresponding author:

KARA SUKRAN

e-mail: sukran.kara@deu.edu.tr 


\title{
Preserving textile objects in Romanian wooden churches. Case study of the heritage wooden church form Oradea, Romania
}

\author{
DOI: 10.35530/IT.071.02.1633
}

IOAN OANA

LILIANA INDRIE

AURELIA ONET

DORINA OANA
DORINA CAMELIA ILIES GRIGORE VASILE HERMAN

ALEXANDRU ILIEȘ FLORIN MARCU

\section{ABSTRACT - REZUMAT}

Preserving textile objects in Romanian wooden churches. Case study of the heritage wooden church form Oradea, Romania

It is important to investigate the indoor air quality, the microbial concentration of indoor air and surfaces for preserving the cultural heritage. In what regards the microclimate inside the historic monument, the wooden church, the temperature and relative humidity were monitored using the thermo-hygrometer with data function logger "Klimalogg Pro" (eight sensors), October-December 2018, the thermos-camera "Thermal Imaging Camera FLIR I7" and "Digi-Sense Data Logging Luxmeter". Image analysis were also performed using digital image processing techniques (ARCGIS), mapping the areas damaged by temperature, humidity and also by rainwater infiltrated on canvas paintings, biodegradation, anthropically degraded areas etc. Isolation of microorganisms from the two canvas paintings and indoor air were taken though specific method, analyses showing the presence of microorganisms on the paintings, possible human pathogens especially for people with low immunity. A high fidelity database with the state of patrimony objects preserved in the Romanian wooden church and perspectives for their proper conservation could be created at a certain moment.

Keywords: heritage wooden church, microbial, microclimate, preserve, canvas paintings, Romania

Prezervarea obiectelor textile din bisericile de lemn românești. Studiu de caz biserica de lemn patrimoniu din Oradea, România

Pentru prezervarea patrimoniului cultural este important să se analizeze calitatea aerului din interiorul clădirilor și concentrația microbiană a aerului. În ceea ce privește microclimatul din biserica de lemn, monument istoric, temperatura și umiditatea relativă au fost monitorizate în perioada octombrie-decembrie 2018, folosind termo-higrometrul cu functie data logger "Klimalogg Pro" (opt senzori), camera de scanare termică "FLIR I7" și "Luxmetru Digi-Sense Data Logger". Analiza imaginilor a fost realizată folosind tehnici de prelucrare digitală a imaginilor (ARCGIS), cu cartografierea zonelor deteriorate de temperatură, umiditate și apa de ploaie infiltrată prin acoperiș și care afectează tablourile pictate pe pânză, biodegradarea, zone degradate din cauze antropice etc. Izolarea microorganismelor de pe cele două picturi pe pânză și din aerul interior a fost realizată prin metode specifice, analizele arătând prezența microorganismelor, care sunt posibili agenți patogeni umani, în special pentru persoanele cu imunitate scăzută. În viitor, ar putea fi creată o bază de date cu starea obiectelor de patrimoniu păstrate în bisericile de lemn din România și perspective pentru buna conservare a acestora.

Cuvinte-cheie: biserica de lemn patrimoniu, microbian, microclimat, prezervare, pictura pe pânză, România

\section{INTRODUCTION}

The old orthodox wooden church "Saint Martyrs Brâncoveanu and his sons", Oradea - Bihor county, is a historical monument built between 1760-1762 in Letca (Sălaj county, Romania), and relocated in 1990 in the campus of the University of Oradea (figure 1). The historic monument is built of wooden beams (durmast and hornbeam) [1-2], and is located on a river stone foundation. Since 2010, the wooden church is on the new list of historical monuments (BH-II-m-B-20958 m). The original decoration was made "in the early 19th century, with vivid colors and rich floral borders which were partly destroyed" [3]; the interior no longer retains its original aspect, being plated and repainted.
Among the textile objects preserved in the wooden church that we propose to analyze in the study are also paintings on canvas. At the entrance, in the narthex, the Virgin Mary with baby Jesus are painted on the ceiling. The painting is made on a blue background, and the Virgin Mary and baby Jesus are represented in warm and bright colors, being surrounded by Archangels Michael and Gabriel. The technique used is called "al secco", and the painting was performed in tempera with egg emulsion on dry plaster. On the opposite side of the altar, there is a canvas painting in oil, where the focus is on three Archangels painted in a circle, while on the sides two Archangels who protect them are represented.

We monitored the microclimate (temperature, humidity, luminosity) inside the wooden church between 


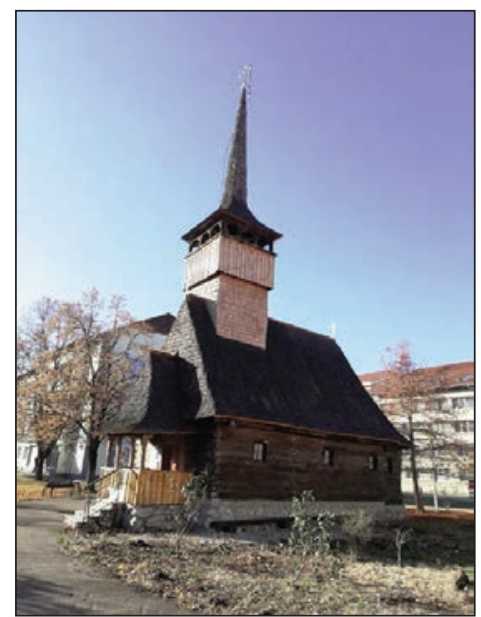

Fig. 1. The historic monument wooden church, University of

Oradea, Campus, photo December 2018

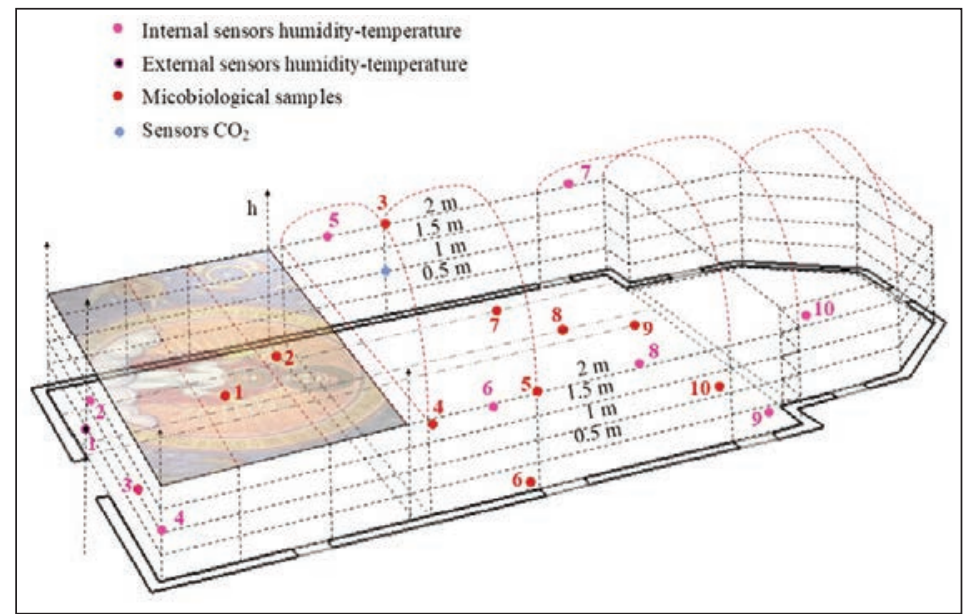

Fig. 2. The location of the sensors for microclimate monitoring, microbiological sampling points, wooden church "St. Martyrs Constantin Brancoveanu and his sons" - "Archangels Michael and Gabriel"

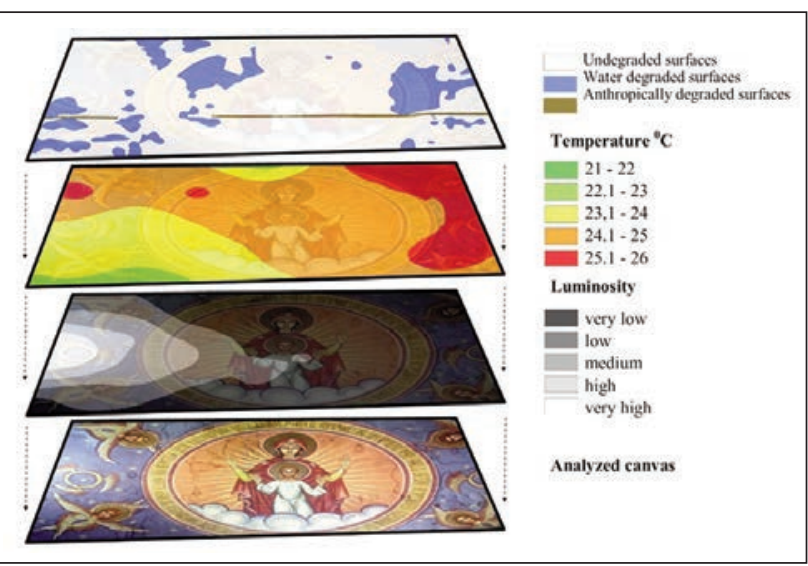

Fig. 3. The distribution of light and heat: $a$ - canvas painting; $b$ - luminosity; $c$ - thermal map applied to the painting; $d$-surfaces degraded by pluviality, biodegradation and anthropic elements

October and December 2018 (figure 2), and microbiological samples from air and paintings were collected and analyzed [4].

We performed the mapping of areas degraded by temperature, humidity and rainwater infiltrated on painted canvas prior to the change of the shingle roof before 2016, biodegradation and anthropic deterioration in order to establish the damaged or vulnerable areas. The distribution of light and heat on the painted canvas at different moments of the day and season and their possible influence on the canvas paintings were also analyzed (figure 3 ).

\section{CASE STUDY}

\section{Literature review}

In Romania few researches are approaching the biodeterioration of textiles support for painting in religious places: was analysed the biodeterioration inside of some Romanian wooden churches [4-5]; the development of micro-fungi on the surface of paintings induces aesthetical, mechanical and biochemical decay [6] investigates the preservation state of the painting inside the wooden church [7-11] focused on biodegradation problems. In international scientific literature, studies on the biodeterioration of textiles support for painting in religious places do not lack: Merritt 1993, wrote about causes, detection, prevention of mould and mildew on textiles [12]; the most frequent biodeteriogens of textiles [13]. Jain P., 2008, has a special chapter dedicated on microbial degradation of textiles [14]. Abdel-Kareem, O., 2010 refers to the monitoring, controlling and preventing the fungal deterioration of textiles in the museum of Jordanian heritage, especially to the disinfection of fungal deteriorated textiles with some fungicides that are safe for both textile objects and conservators [15]. The same author studied also fungal microflora deteriorating historical textiles in the Egyptian and Coptic Museums, Cairo. The investigation including the canvases of easel paintings stored religious institutions in Slovenia, initially indicated relatively widespread fungal contamination [16]. Some paper presents the method of treatment of tapestry textile, linen which was stretched on wooden frame treated by anti-fungal substance [17]. Other authors presented a microscopy study with focus on the cellulolytic fungi action on cotton fiber's physical aspect [18], or analyses fungi and bacteria on artworks in different environments, considering the human/artefact/environment system as being very dynamic [19].

\section{Method}

Image analysis [20] were used in order to extract information from one or more images; digital image processing techniques were used [21]. The ArcGIS system has been used to highlight spatial trends, because it easier to visualize, analyse and interpret available data in order to understand the trends of evolution [22-29]. Isolation of microorganisms from paintings were done through specific means, samples of $1 \mathrm{~cm}^{2}$ from the surface of two canvas paintings were taken using sterile cotton swabs [4, 30-31]. 
Cotton swabs were submerged in $1 \mathrm{~mL}$ of sterile distilled water and decimal dilutions were performed. Suitable dilutions of each sample were inoculated into nutrient agar on petri dishes to identify bacteria and on Sabouraud agar with chloramphenicol for isolation of fungi. They were incubated at $37^{\circ} \mathrm{C}$ for $72 \mathrm{~h}$ (isolation of bacteria) and at $25^{\circ} \mathrm{C}$ for $5-7$ days (isolation of fungi). After this period, the colonies were counted with the colony counter. Cultural and morphological characteristics of fungal colonies were observed and the identification was performed according to different manuals [32]. Regarding the microclimate inside the historic monument wooden church the temperature and relative humidity of the air was monitored using the thermo-hygrometer with data function logger „Klimalogg Pro”, which allowed detailed records of temperature and humidity values as well as their active monitoring in the months of October-December 2018 (eight sensors). Luminosity analysis was performed with "Digi-Sense Data Logging Luxmeter", while the temperature was scanned with "Thermal Imaging Camera FLIR I7" thermo-camera.

\section{Discussions}

At the suitable temperature and relative humidity, the air microbiota can coexist together with the collections and people in a specific ecosystem without causing significant damages. The oil painting in the church museum is made on cotton canvas also due to its quality to be easily painted. Cotton is a natural cellulosic fiber unicellular [33-34], characterized by a very high stability of the fiber in textile structures (fabrics) due to the twist of its fibers and surface structure (a good fixation of the fiber in the products provide them a longer use, stability in different loads and a pleasant aspect). The temperature is an important factor contributing to the deterioration of the paintings: high temperature values (figure $3, c$ ) lead to an accelerated degradation of unstable materials. In addition, low temperatures make organic materials more perishable. Also, big temperature differences in the room can contribute in time to damage, cracks or support detachments. The thermal degradation of cellulose fibers is also accompanied by hydrolysis and oxidation. The resistance of a cotton fabric, heated in the presence of air, decreases as the temperature rises. In the case of low temperature, the organic components became more friable. In the absence of air and humidity, the heated cellulosic fibers suffer lower changes than in their presence.

In terms of humidity, (relative humidity) U.R. variations create tensions between the components of a painting, as well as between the painting and its support. The hygroscopicity of cotton is medium, but in standard conditions (temperature between $20^{\circ} \mathrm{C} \pm 2{ }^{\circ} \mathrm{C}$ and $65 \% \pm 5 \%$ relative air humidity) absorbs between $7-8 \%$ water [35-36]. However, if the humidity exceeds $68-70 \%$ it favours not only the development of microorganisms on organic materials, but also the destruction of the internal structure of cellulosic fibers [37]. Depending on the moisture persistence, isolated or extended stains may appear on the surface (figure 3). Pigments can suffer a physical alteration, which does not involve switching to another chemical compound, but there is a phenomenon of colour "darkening" due to a high degree of hydration (figure $3)$. The phenomenon can definitely influence the condition of the textile fiber, the preparation, the colours and the vernil [38]. Increased humidity can accelerate chemical and photochemical processes that result in colour change, material fragility, decreased mechanical strength of textile fibers etc., and it can lead to increased volume, swelling, wrinkling and softening of natural adhesives (figure 4). In time, a decreased moisture affects the state of health of organic objects: furniture, wooden objects, paintings etc. If humidity decreases below $50 \%$, but especially below $40 \%$, it first dehydrates the materials and decreases the mechanical strength of the parts, causes the volume to decrease, scorching, loss of elasticity, appearance of micro fissures, exfoliation, removal of natural adhesives (figures $3, d$ and 4) [38]. Following the exposure of the painting to the natural light radiation and the different intensity of the solar radiation throughout the day, by overlapping the images one can see in the figure (figure $3, b$ ) oxidative degraded areas due to the impact of these radiation on the painting, both from the point of view of colour intensity and resistance of the exposed fabric structure. Thus, it can be noticed that in places where the natural luminous intensity was higher, discoloration areas of the painted canvas appeared (figure $3, b)$. The resistance of a cotton fabric decreases after 6-7 days of exposure to ultraviolet rays [35-36].

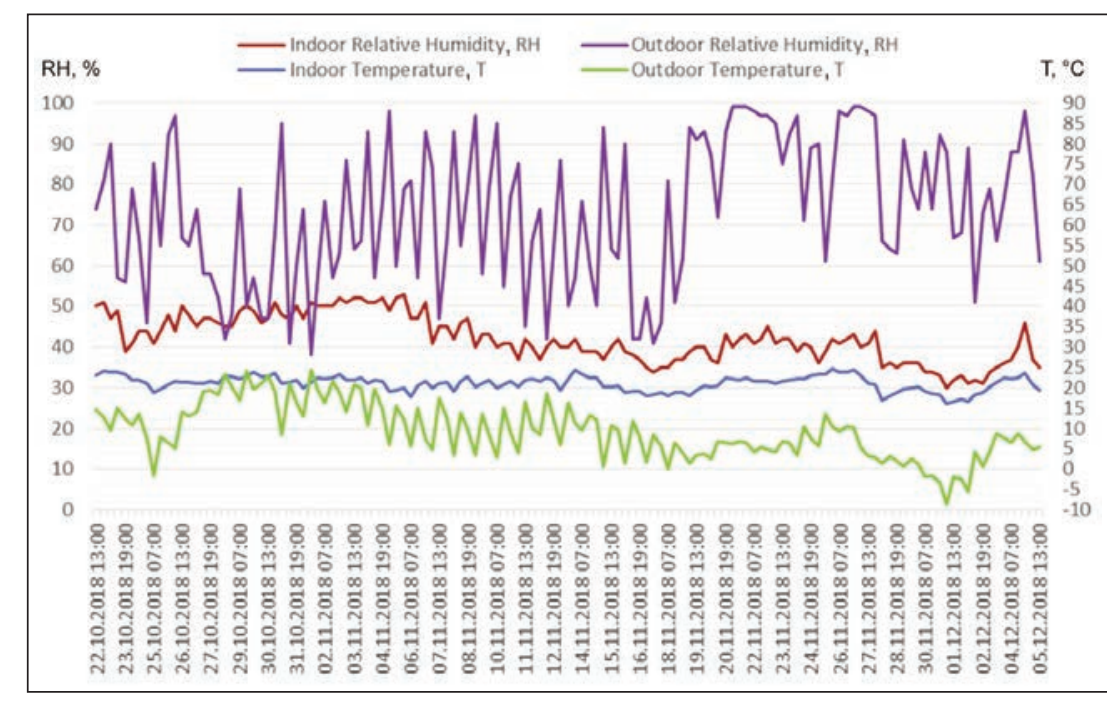

Fig. 4. Variation of the air temperature and the relative humidity indoor and outdoor of the heritage wooden church, in the monitoring period $22 / 10 / 2018-05 / 12 / 2018$ 
Ultraviolet rays can also cause yellowing of exposed materials, discoloration, and loss of mechanical resistance in the case of wall paintings. In addition, hydrogen peroxide molecules have been identified both on the surface and in the capillaries of a fabric exposed to light. Under the action of light and atmospheric agents (temperature and humidity), the resistance of fabrics decreases as follows: with $26.5 \%$ after one month, with $45.3 \%$ after two months and with $60.7 \%$ after 3 months [35-36].

The biochemical degradation of cellulosic fibers occurs due to the action of microorganisms, and the attack of cotton can be recognized by the appearance of some yellow, brown or black stains, where the local resistance is diminished and the dyeing is uneven. This can be freely noticed on the paintings exhibited in the church, especially in the joining areas, where the variations in humidity and temperature are higher (figure 4). Increasing thermohygrometric values at the repository, microorganisms can accelerate biodeterioration [39]. Microorganisms participate in the mineralization of paints through biofilm formations on the surfaces causing aesthetic and structural damage. Various types of organisms are involved in paint spoilage and they include bacteria, fungi, algae, and protozoa. The interactions between these organisms can enhance or retard the overall rate of paint biodegradation [40]. Different fungal genera were isolated from the two paintings choose to be investigated for biodeterioration. On the painting on canvas inside of the heritage wooden church were isolated: Streptomyces sp., Arthrographis sp., Beauveria $s p$. concerning the bacteria presence on the painting canvas, Bacillus sp. has been isolated and filamentous bacteria from genera Streptomyces. The actinomycetes, in particular Streptomyces, are capable of decomposing relatively complex organic substances such as cellulose, pectin, chitin, proteins, and humic substances [4, 40].

Also, based on microscopic techniques were identified unknown bacteria strains with the shape cocci and bacilli. Paint spoilage by bacteria in addition to fungi and algae, bacteria are also involved in the biofilm formation followed by reduced durability of structures. While fungal and algal growths are often visible to the naked eye, bacteria can be present on an apparently clean surface in sufficient numbers to exert adverse effects. This situation conditions the surfaces to absorb humidity that helps the microbial adherence and the subsequent biofilm formation [30, 41]. The organic components in paintings represent a good source of nutrition for a wide range of heterotrophic microorganisms. However, biological attack occurs only when there are favourable environmental conditions, and such conditions are often found in old churches without any control of the humidity and temperature [4, 42].

The micro flora attacking paintings include virtually all species of micro-fungi because the variety of organic components of these works of art can represent a carbon source for practically all species. In addition, they show a great tolerance for environmental conditions and can use condensation moisture [43]. In fact, in paintings on canvas, the microbial attack usually starts from the reverse side, because the glue sizing increases the natural susceptibility of textiles. Then the biodeteriogens "penetrate inside canvas reaching the backside of the paint layer, causing cracks and detachment, while the cellulose hydrolysis creates differences of adhesion between the paint layer and the canvas itself" [4, 44]. Biological attack on the paint layer is less frequent than on the support and depends on the nature of pigments. "The most susceptible to biological attack are casein and egg distemper, emulsion distemper and linseed oil in this order" [4].

Watercolours contain only a small amount of organic binder and are, therefore, susceptible to microbial deterioration as pastels [45]. The growth of a micro fungal mycelium by a microscopical germinating spora is quite rapid, with radial development, and it became macroscopically visible in few days. The development of micro fungi on the surface of paintings induces aesthetical, mechanical and biochemical decay. In fact, the growing mycelium spread over the paints, masking design and colour, while the growth of hyphae and fruiting bodies inside the support can cause friability and loss of the paint layer.

As environmental microorganisms can deteriorate the different supports of heritage significance [31, 41] as well as affect human health as allergies and skin affections [39]. Streptomyces spp., commonly widespread bacteria that is usually saprophytic for humans and which can usually cause localized fistulized cutaneous nodules and rarely cause severe invasive infections. Most of these cases may occur in patients with low immunity. Such invasive infections have also been reported in the presence of pre-existing conditions associated with low immunity: AIDS infection, oral corticosteroid treatment, the presence of a central venous catheter or of an aortic heart valve prosthesis [4, 46]. Arthrographis GenusArthrographis kalrae, one of the five existing species, is a saprophytic medium fungus found mainly in soil and in fertilizer, and which has rarely been identified as a possible human pathogen. According to specialist research, few cases of opportunistic infections attributed to this pathogen have been described: pulmonary infection, endocarditis, sinusitis, meningitis, keratitis, and onychomycosis affecting both immunocompromised and immunocompromised patients $[4,47]$. Beauveria sp. is a widely spread fungus but is rarely reported as a human pathogen. Although a rare event, studies show that systemic infection with Beauveria is possible for patients undergoing immunosuppressive treatment $[4,48]$.

\section{CONCLUSIONS}

For a better preservation of textile objects inside the heritage wooden church, it is necessary [49] to continuously monitor the interior microclimate, compressive the microbial concentration of the air, because 
the presence of these fungal genera and bacteria on paintings results to be highly risky both for their preservation and for the human health. It is necessary to better isolate the rooms where the paintings are exposed, a better ventilation, as well as maintaining the standard conditions of relative air humidity between $65 \% \pm 5 \%$ and of temperature between $20^{\circ} \mathrm{C} \pm 2^{\circ} \mathrm{C}$. A high fidelity database regarding the state of patrimony objects preserved in Romanian wooden churches and the perspectives for their proper preservation can be created. It is recommended to change the air conditioner filters, carpets, and to sanitize the interior of the wooden church and of paintings etc.

\section{ACKNOWLEDGEMENTS}

The monitoring and sampling inside of the wooden church is not invasive. The research was possible by equal scientific involvement of all authors. The authors wish to thank to anonymous reviewer for their thoughtful suggestions and comments and to acknowledge the support of the Grant PN-III-P1-1.2-PCCDI-2017-0686.

\section{REFERENCES}

[1] Baias, Ș., Gozner, M., Herman, G.V., Măduța, F., Typology of wooden churches in the drainage basins of Mureș and Arieș, Alba county. In: Analele Universității din Oradea, Seria Geografie, 2015, 25, 2, 221-233

[2] Ilieș, A., Baias, Ş., Bisericile din lemn "perle" ale arhitecturii rurale, In: Ilies Alexandru (Eds.): Crişana - Maramureş: Atlas geografic al patrimoniului turistic , Editura Universităţii din Oradea, 2014

[3] Godea, I., Cristache-Panait, I., Chiriac, A., Malinas, M., Historic monuments from Eparhia of Oradea, Bihor, Salaj, Satu Mare Counties, Wooden churches, Press of Romanian Orthodox Diocese, Oradea, 1978, 341

[4] Ilies, D.C., Onet, A., Herman, G., Indrie, L., Ilies, A., Burta, L., Gaceu, O., Marcu, F., Baias, S., Caciora, T., Marcu, A.P., Oana, I.P., Costea, M., llies, M., Wendt, J., Mihincau, D., Exploring the indoor environment of heritage buildings and its role in conservation of valuable objects, In: Environmental Engeneering and Management Journal, 2019, 18, 12, 2579-2586

[5] Bucsa, C., Bucsa, L., Romanian Wooden Churches Wall Painting Biodeterioration, In: Wood science for conservation of cultural heritage-Braga 2008, Firenze University Press, 2010, 1000-1006

[6] Herbel, R.G., Biserica de lemn din satul Cetăţeaua, comuna Mitrofani, judeţul Vâlcea, In: Revista Transilvania, 2015, 3-4, 89-95

[7] Bucsa, L., Halasz, A.-M., Biserica de lemn din Bulgari, judeţul Sălaj, particularităţi de construcţie şi probleme de biodegradare, In: "Caietele restaurării", Bucharest, Ed. ACS, 2013, 178-188

[8] Ilieș, D.C., Oneț, A., Marcu, F., Gaceu, O.R., Timar, A., Baias, Ș., Ilieș, A., Herman, G.V., Costea, M., Țepelea, M., Josan, I., Wendt, J., Investigations regarding the air quality in the historic wooden church in Oradea City, Romania, In: Environmental Engineering and Management Journal, 2018, Available at http://www.eemj.icpm.tuiasi.ro/pdfs/ accepted/204 294 Ilie\%C8\%99 17.pdf

[9] Ilieș, D.C., Buhaș, R., Ilieș, A., Gaceu, O., Oneț, A., Buhaș, S., Rahotă, D., Dragoș, P., Baiaș, Ș., Marcu, F., Oneț, C., Indoor air quality issues. Case study: the multipurpose sports hall of the University of Oradea, In: Environmental Engineering and Management Journal, 2018, Available at http://www.eemj.icpm.tuiasi.ro/pdfs/accepted/ 213544 llies 17.pdf

[10] Ilieș, D.C. Oneț, A., Wendt, J.A., Ilieș, M., Timar, A., Ilieș, A., Baias, Ș., Herman, G.V., Study on Microbial and Fungal Contamination of the Air and Wooden Surfaces Inside of a Historical Church from Romania, In: Journal of Environmental Biology, 2018, 39, 6, 980-984

[11] Onet, A., Ilies, D.C., Buhas, S., Rahota, D., Ilies, A., Baias, S., Marcu, F., Herman, G.V., Microbial air contamination in indoor environment of university Sport Hall, In: Journal of Environmental Protection and Ecology, 2018, 19, 2, 694-703

[12] Merritt, J., Causes, detection, and prevention of mold and mildew on textiles. Conserve O Gram Washington, DC: National Park Service, 1993, 16, 7, 1-10

[13] Tiano, P., Biodegradation of cultural heritage: decay mechanisms and control methods, In: Seminar article, New University of Lisbon, Department of Conservation and Restoration, 2002, 7-12

[14] Jain, P.C., Microbial degradation of grains, oil seeds, textiles, wood, corrosion of metals and bioleaching of mineral ores, 2008

[15] Kareem-Bbdel, O., Monitoring, controlling and prevention of the fungal deterioration of textile artifacts in the museum of Jordanian heritage and from Egypt, In: Mediterranean Archaeology and Archaeometry, 2010, 10, 2, 85-96

[16] Kavkler, K., Gunde-Cimerman, N., Zalar, P., Demšar, A., Fungal contamination of textile objects preserved in Slovene museums and religious institutions, In: International Biodeterioration \& Biodegradation, 2015, 97, 51-59

[17] Fahim, N.K., El Said Ziddan, Y., Rahim, A., Ahmed, S., Practical study on treatment of selected decorated tapestry in applied art museum, Cairo, In: International Journal of Conservation Science, 2013, 4, 4, 423-432

[18] Popescu, C., Oprică, L., Pricop, D., Bălan, G., Mureşan, R., Creangă, D., Microscopy investigation of cellulolytic fungi action on cotton fibers, In: Rom. J. Biopys, 2014, 24, 1, 65-67

[19] Di Carlo, E., Chisesi, R., Barresi, G., Barbaro, S., Lombardo, G., Rotolo, V., Sebastianelli, M., Travagliato, G., Palla, F., Fungi and bacteria in indoor Cultural Heritage environments: microbial-related risks for artworks and human health, In: Environment and Ecology Research, 2016, 4, 5, 257-264

[20] Venkatakrishnan, S., Kalyani, C., Basics of image processing technologies, In: International Journal of World Research, India, 2016, 1, 34, 55-58

[21] Solomon, C., Breckon, T., Fundamentals of Digital Image Processing: A practical approach with examples in Matlab, John Wiley \& Sons, 2011

[22] Biali, G., Stătescu, F., Lucian, P.V., Mapping nitrate levels in groundwater using G/S, In: Environmental Engineering \& Management Journal (EEMJ), 2013, 12, 4, 807-814

[23] Herman, G.V., Using Geographical Information (GIS) System for Management of Flood Risks in the Somes Plain, In: Cross-Border Partnership with Special Regard to the Hungarian - Romanian - Ukrainian Tripartite Border, Book Editors Ioan Horga, Istvan Suli Zakar, Publishing House University of Debrecen Press; 2010, 175-179, ISBN 978-606-10-0153-8 
[24] Ilieș, A., Wendt, J.A., Ilieș, D.C., Herman, G.V., Ilieș, M., Deac, A.L., The patrimony of wooden churches, built between 1531 and 2015, in the Land of Maramures, Romania, In: Journals of Maps 12(Supp1), 2016, 597-602

[25] Johnston, K., Ver Hoef, J.M., Krivoruchko, K., Lucas, N., Using ArcGIS geostatistical analyst, Redlands: Esri, 2001, 380

[26] Romocea, T., Onet, A., Sabău, N.C., Onet, C., Herman, G.V., Pantea, E., Change of the groundwater quality from industrial area Oradea, Romania, using Geographic Information Systems (GIS), In: Environmental Engineering \& Management Journal (EEMJ), 2018, 17, 9, 2189-2199

[27] Longey, P.A., Goodchild, M.F., Maguire, D.J., Rhind, D.W., Geographic information systems and science, John Wiley \& Sons, 2005

[28] O'Connor, M., Zabik, M., Cady, C., Cousens, B., Chiarenzelli, J., Multi-element analysis and geochemical spatial trends of groundwater in rural northern New York, In: Water, 2010, 2, 2, 217-238

[29] Moody, R., van Ast, J.A., Implementation of GIS-based applications in water governance, In: Water resources management, 2012, 26, 2, 517-529

[30] Guiamet, P., Borrego, S., Lavin, P., Perdomo, I., de Saravia, S.G., Biofouling and biodeterioration in materials stored at the Historical Archive of the Museum of La Plata, Argentine and at the National Archive of the Republic of Cuba, In: Colloids and Surfaces B: Biointerfaces, 2011, 85, 2, 229-234

[31] Pinzari, F., Pasquariello, G., De Mico, A., Biodeterioration of paper: A SEM study of fungal spoilage reproduced under controlled conditions, In: Macromolecular Symposia, 2006, 238, 1, 57-66

[32] Madigan, M., Martinko, J., Dunlap, P., Clark, D., Food poisoning and food borne diseases - Staphylococcal food poisoning, In: Brock, Biology of microorganisms (12t ${ }^{\text {h }}$ Edition). Pearson-Benjamin Cummings, San Francisco, 2009, 1051-1052

[33] Kljun, A., El-Dessouky, H.M., Benians, T.A., Goubet, F., Meulewaeter, F., Knox, J.P., Blackburn, R.S., Analysis of the physical properties of developing cotton fibres, In: European Polymer Journal, 2014, 51, 57-68

[34] Hsieh, Y.L., Chemical structure and properties of cotton, In: Cotton: Science and technology, 2007, 3-34

[35] Bordeianu, D.L., Fibre textile, Editura Universității din Oradea, 2005

[36] Gribincea, V., Bordeianu, L., Fibre textile-proprietăți generale, Editura Performantica, Iași, 2002

[37] Turcu, M., Conservarea pieselor de muzeu, Editura Fundaţiei "România de Mâine", 2008

[38] Oprea, F., Etiopatogenia operei de artă şi a materialelor structurale. Note de curs universitar, Editura MOSIM, Bucureşti, 2010, 167

[39] Huttunen, K., Hyvärinen, A., Nevalainen, A., Komulainen, H., Hirvonen, M.R., Production of proinflammatory mediators by indoor air bacteria and fungal spores in mouse and human cell lines, In: Environmental Health Perspectives, 2003, 111, 1, 85-92

[40] Ravikumar, H.R., Rao, S.S., Karigar, C.S. Biodegradation of paints: A current status, In: Indian Journal of Science and Technology, 2012, 5, 1, 1977-1987

[41] Florian, M.L.E., Fungal Facts. Solving Fungal Problems, In: Heritage Collections, Archetype Publications, London, UK, 2004

[42] Wemedo, S.A., Ede, P.N., Chuku, A., Interaction between building design and indoor airborne microbial load in Nigeria, In: Asian Journal of Biological Sciences, 2012, 5, 183-191

[43] Ciferri, O., Microbial Degradation of Paintings, In: Appl Environ Microbiol., 1999, 65, 3, 879-885

[44] Strzelczyk, A.B., Kuroczkin, J., Krumbein, W.E., Studies on the microbial degradation of ancient leather bookbindings: Part I, In: International Biodeterioration, 1987, 25, 1, 3-27

[45] Wan, S.D., Agrawal, O.P., Fungal flora of miniature paper paintings and lithographs, In: Int. Biodeterior., 1986, 22, 2, 95-99

[46] Riviere, E., Neau, D., Roux, X., Lippa, N., Roger-Schmeltz, J., Mercie, P., Longy-Boursier, M., Pulmonary streptomyces infection in patient with sarcoidosis, France, 2012, In: Emerging Infectious Diseases, 2012, 18, 11, 1907-1909

[47] Denis, J., Sabou, M., Degot, T., Candolfi, E., Letscher-Bru, V., First case of Arthrographis kalrae fungemia in a patient with cystic fibrosis, In: Medical mycology case reports, 2016, 14, 8-11

[48] Henke, M.O., de Hoog, G.S., Gross, U., Zimmermann, G., Kraemer, D., Weig, M., Human deep tissue infection with an entomopathogenic Beauveria species, In: Journal of clinical microbiology, 2002, 40, 7, 2698-2702

[49] Tudor, L., Change in Textile and Clothing Industry, In: Industria Textila, 2018, 69, 1, 37-43,http://doi.org/ 10.35530/IT.069.01.1449

Authors:

IOAN OANA ${ }^{1}$, LILIANA INDRIE ${ }^{1}$, AURELIA ONET ${ }^{2}$, DORINA OANA ${ }^{1}$, DORINA CAMELIA ILIEȘ ${ }^{3}$, GRIGORE VASILE HERMAN ${ }^{3}$, ALEXANDRU ILIES ${ }^{3}$, FLORIN MARCU ${ }^{4}$

${ }^{1}$ University of Oradea, Faculty of Energy Engineering and Industrial Management, Department of Textile,

Leather and Industrial Management, 4, B.St. Delavrancea Street., 410058, Oradea, Romania e-mail: oanaioanpavel@yahoo.com, liliindrie@yahoo.com

2University of Oradea, Faculty of Environmental Protection, 26, Gen. Magheru Street, Oradea, Romania e-mail: aurelia_onet@yahoo.com,

${ }^{3}$ University of Oradea, Faculty of Geography, Tourism and Sport, $1^{\text {st }}$ University Street, 410087, Oradea, Romania e-mail: iliesdorina@yahoo.com, grigoreherman@yahoo.com, ilies@uoradea.ro

${ }^{4}$ University of Oradea, Faculty of Medicine and Pharmacy, Oradea, Romania e-mail: mfmihai27@yahoo.com

Corresponding author:

OANA IOAN

e-mail: oanaioanpavel@yahoo.com 


\section{Qualitative classification of woven fabrics produced from recycled threads of cotton and blends}

DOI: $10.35530 / \mathrm{IT} .071 .02 .1638$

KALKANCI MIHRIBAN

ABSTRACT - REZUMAT

Qualitative classification of woven fabrics produced from recycled threads of cotton and blends

In this study, shirting fabrics were woven with weft threads produced from blends of recycled cotton fibers, original cotton fibers and original polyester fibers (100\% original cotton, $100 \%$ recycled cotton, $35 \% / 65 \%$ polyester/recycled cotton, $35 \% / 65 \%$ polyester/original cotton, $50 \% / 50 \%$ polyester/recycled cotton, 50\%/50\% polyester/original cotton). The produced fabrics were investigated in terms of fabric defects by using fabric quality control machines after wet treatment procedures have been carried out. The types and numbers of defects detected during quality control were recorded and graded according to Graniteville 78 Fabric Inspection System and were classified accordingly. All fabrics were evaluated in terms of fabric quality.

Keywords: recycled fabric, fabric quality, grading, tailorability

Clasificarea calitativă a țesăturilor produse din fire de bumbac și în amestec reciclate

În acest studiu, țesăturile pentru confecţionarea cămăşilor au fost realizate din fire de bătătură produse din amestecuri de fibre de bumbac reciclate, fibre de bumbac originale și fibre de poliester originale $1100 \%$ bumbac original, $100 \%$ bumbac reciclat, 35\%/65\% poliester/bumbac reciclat, 35\%/65\% poliester/bumbac original, 50\%/50\% poliester/bumbac reciclat, $50 \% / 50 \%$ poliester/bumbac original). Țesăturile produse au fost investigate în ceea ce privește defectele, folosind echipamente de control al calității după ce au fost aplicate operațiile de tratament umed. Tipurile și numărul de defecte detectate în timpul controlului calității au fost înregistrate și clasificate în conformitate cu sistemul de inspecție a țesăturilor Graniteville 78. Toate țesăturile au fost evaluate din punct de vedere calitativ.

Cuvinte-cheie: ţesătură reciclată, calitatea ţesăturii, gradare, adaptabilitate

\section{INTRODUCTION}

For a sustainable life style, several strategies have come to the forefront in the design and production stages of textiles and apparel manufacturing. These strategies are reduce, reuse, energy recovery and recycling. Almost $100 \%$ of textiles are suitable for recycling.

Textile recycling industry is a feasible and economically sustainable industry provided that textile wastes are systemically collected and handled [1]. On the other hand, worn-out textile products should not cause harm to the environment or to human health during their afterlife stage via incineration, decaying or landfilling. The most efficient solution is recycling [2]. In other words, recovering fibers of the worn-out textile products [3]. As the raw materials, machinery, energy type and cost, environmental interactions during processes in the course of production as well as the recyclability of textile products are not the same, it is very difficult to investigate recycling in textiles under one title [4]. In order to recover fibers from textile waste and reuse them in conventional textile processes, the wastes should be open up to fibers and separated. The fibers can be sorted via use of fabric shredders (disintegrators) equipped with thread opening elements. Separation of component fibers following fabric disintegration is the most important step in terms of fiber recovery in waste of blend textile wastes [5]. Depending on the final use, the fibers are also utilized in blends. Following, the fibers are prepared for spinning for weaving or knitting via being cleaned and blended in carding machines [6]. There are many different spinning systems in textile manufacturing. Among the spinning systems, ring, Open-End Rotor spinning, airjet spinning and compact spinning systems are still the widely most used spinning systems [7]. At the same time, recycling mostly takes place in the spinning stage. Open-end rotor spinning system, which allows use of fibers shorter than ring spinning mostly, utilize recycled fibers [8].

Different textile recycling systems have been developed including product recovery, chemical recovery and thermal recovery [9]. A number of research studies have been conducted for investigating properties of threads and fabrics produced from wastes of textiles [10-11] and home textiles [12]. In similar studies, wastes of cotton fabrics and indigo-dyed denim fabrics were dissolved in suitable solvents, then fibers were spun from them and the properties of these fibers were investigated [13-14]. Structural and 
mechanical characteristics of fabrics recycled from textile wastes and potential utilization areas [15-18], possibility of polyester/cotton blend reuse in composites [19], quality of yarn at different blend ratios [20] and possibility of recycled yarn production and fabrication parameters have been subjects of different studies [21-27]. However, studies related to investigation of fabric defects produced from recycled and original fibers are limited.

Defect formation during woven fabric formation is inevitable no matter what type of raw material is used. In order to eliminate interpretation differences in defect characterization, standards including TS471, ASTM D3990 and BS7342 were used [28]. Woven fabric defects are deviations, which occur regionally, affect fabric appearance, change fabric structure and cause special changes in regional limitation [29]. Fabric defects have been defined by Turkish Standards Institute as "defects in fabrics which are caused by the yarn, auxiliary material, labor, machinery, equipment or working method, and can be seen and evaluated with eye and impair fabric appearance" [30].

During classification of fabric rolls as the first or the second quality, different defect grading systems can be utilized. The systems, which enjoy common use, are 4-point system, 10-point system, Graniteville 78 system and The Worth Street Rules Systems. It is necessary to apply necessary quality control inspections on fabrics and conduct objective evaluation before accepting them for apparel manufacturing processes [31]. However, the 4-point, 10-point and the Worth Street Rules systems do not reflect the effect of defects due to their grading method. In 4-point and the Worth Street Rules systems, only 4 points can be allocated to a yard. In 10-point system, a yard can only get 10 points. On the other hand, the points to be attained to a yard square of fabric is determined by the fabric width in Graniteville 78 System. Moreover, defects like stains which do not deteriorate acceptability of fabrics for apparel manufacturing processes do not take points [28]. Thus, Graniteville 78 system is among the most suitable fabric grading systems for determining if the fabric is acceptable for apparel manufacturing processes. In this study, Graniteville 78 System has been adopted as it was aimed to detect irreparable defects, which negatively affect the apparel. In table 1, defect points corresponding to defect dimensions are given.

The Graniteville 78 system is a grading system that was developed by Graniteville Firm in 1975 for evaluating standard woven and knitted fabric qualities. The defect points determined by Graniteville 78 system are given in table 1 . In this system, only defects that have to be cut out from the fabric or that render the final product second quality are taken into consideration. Each yard-square or meter-square fabric can receive maximum 4 points. The maximum points that a yardsquare fabric can get is determined by the fabric width. The ninth of fabric width in inches designates the maximum defect grade. To give an example, the maximum defect point to be given to a fabric the width of which is 48 inches is $48 / 9=5.33$ or 6 [28].

Table 1

\begin{tabular}{|c|c|}
\hline \multicolumn{2}{|c|}{$\begin{array}{c}\text { DEFECT DIMENSIONS AND CORRESPONDING } \\
\text { PENALTY POINTS ACCORDING TO GRANITEVILLE } \\
78 \text { SYSTEM }[31,32]\end{array}$} \\
\hline Defect length & Penalty points \\
\hline For defects up to $23 \mathrm{~cm}$ (9 inch) & 1 \\
\hline For defects $23-46 \mathrm{~cm}$ (9-18 inch) & 2 \\
\hline For defects $46-69 \mathrm{~cm}(18-27$ inch) & 3 \\
\hline For defects $69-92 \mathrm{~cm}$ (27-36 inch) & 4 \\
\hline For defects $92-115 \mathrm{~cm}$ (36-45 inch) & 5 \\
\hline For defects $115-138 \mathrm{~cm}(45-54$ inch) & 6 \\
\hline For defects $138-160 \mathrm{~cm}$ (54-63 inch) & 7 \\
\hline
\end{tabular}

In this study, different shirting fabrics, which were produced for order in a weaving factory, which manufactures shirting fabrics from recycled cotton threads (regenerated threads, as known in the industry), and their blends, have been investigated. The aim was to identify defects that can be seen in apparel manufacturing process in fabrics produced from recycled yarns. The investigated fabrics are classified in terms of their quality according to Graniteville 78 system.

\section{MATERIALS AND METHOD}

\section{Materials}

This study has been conducted in a factory, located in Denizli province, (consisting of spinning and weaving mills), which has 315 weaving machines and produces home textiles (such as bedlinens), shirting and trouser fabrics. In the study, white shirting fabrics were produced using different weft thread blends as per orders. The constructions of weft threads are 100\% r-Cotton, $100 \%$ Cotton, 35\% PES - 65\% rCotton, $35 \%$ PES $-65 \%$ Cotton, $50 \%$ PES - 50\% r-Cotton, $50 \%$ PES - $50 \%$ Cotton. The bales of recycled fibers and slivers used during the production of yarns for the mentioned fabrics are shown in figure 1.
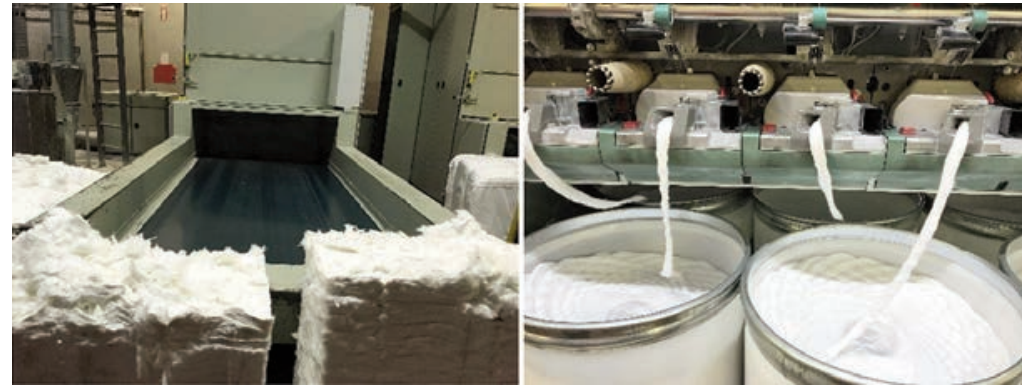

Fig. 1. Recycled fiber bales and slivers used for the production of the fabrics 
STRUCTURAL PROPERTIES OF THE FABRICS

\begin{tabular}{|c|c|c|c|c|c|c|}
\hline \multirow{2}{*}{$\begin{array}{c}\text { Fabric } \\
\text { code }\end{array}$} & \multirow{2}{*}{$\begin{array}{l}\text { Weft thread } \\
\text { raw material }\end{array}$} & \multirow{2}{*}{$\begin{array}{l}\text { Weft thread } \\
\text { NE }\end{array}$} & \multicolumn{2}{|c|}{$\begin{array}{c}\text { Density } \\
\text { (thread/cm) }\end{array}$} & \multirow{2}{*}{$\begin{array}{l}\text { Mass } \\
\left(\mathrm{g} / \mathrm{m}^{2}\right)\end{array}$} & \multirow{2}{*}{$\begin{array}{l}\text { Total } \\
\text { (mt) }\end{array}$} \\
\hline & & & Warp & Weft & & \\
\hline 1 & $100 \%$ r-Cotton & $20 / 1$ & 30 & 24 & 100 & 350 \\
\hline 2 & $100 \%$ Cotton & $20 / 1$ & 30 & 24 & 100 & 350 \\
\hline 3 & $35 \%$ PES - 65\% r-Cotton & $20 / 1$ & 30 & 24 & 100 & 350 \\
\hline 4 & $35 \%$ PES - $65 \%$ Cotton & $20 / 1$ & 30 & 24 & 100 & 350 \\
\hline 5 & $50 \%$ PES - 50\% r-Cotton & $20 / 1$ & 30 & 24 & 100 & 350 \\
\hline
\end{tabular}

The fiber structural properties of the produced fabrics are listed in table 2 . The constructions and production volumes of the produced fabrics are the same. The warp thread is 100 -denier polyester thread and plain weave structure has been adopted for all fabrics. The recycled yarns were produced in the open-end spinning section of the mentioned factory. The recycled fibers were obtained from Uşak province. The length of the polyester staple fiber is $38 \mathrm{~mm}$. In woven fabrics, both weft and warp threads influence the physical and mechanical properties of the fabrics. In this study, no changes have been made in warp density and type. On the other hand, only changes to weft threads were made.

\section{Method}

All fabrics were processed through bleaching in a wet treatment mill and were brought to the factory in white color. Before these fabrics were sent to the receiver apparel manufacturing company, they were manually inspected by using a light board. Following, the inspected fabrics were graded according to Graniteville 78 system in terms of their quality. The defects that are classified in fabric inspection sheets used in the current study can be grouped in three main classes; defects in weft direction, defects in warp direction and other defects. The defects in weft direction are full-width double wefts, half-width double wefts, full-width broken weft, half-width broken weft, stop mark, weft fiber in color, soiledgreased weft, thin-thick weft, excessive weft density. The defects in warp direction are broken warp, excessive warp density, loose-tight warp, warp fiber in color, stained-greased warp, thin thick warp, double warps, missing warp, temple mark; and other defects include slub, bad selvedge, and knot.

\section{FINDINGS}

The fabric defects which were obtained from the inspection of 2100 meters fabric were recorded into inspection sheets according to the determined defect classification. The defects in the outer $3 \mathrm{~cm}$ width were ignored. If a running meter of the fabric includes more than one defect, the greatest defect was recorded to the sheet. The inspected fabrics were graded according to Graniteville 78 system. In the fabric rolls, the obtained defects include fullwidth double wefts, half-width double wefts, full-width groups as defects in weft direction, defects in warp direction and other defects are given in table 3 .

As the weft threads are varied, it was expected that most of the defects would be in the weft direction. It can be said that the defects that are shown in figure 2 , namely, half-width broken weft, fiber in color, thinthick weft, are specific defects which develop during recycled yarn spinning. The half-width broken weft and thick-thin weft defects are caused by the quality of the recycled fibers. As the waste fabric clippings are transformed into the fiber form, loss of strength, and increase in short-length fiber content takes place. These in turn lead to decreased yarn strength which results in weft breakage during weaving. The

Table 3

\begin{tabular}{|c|c|c|}
\hline \multicolumn{3}{|c|}{$\begin{array}{c}\text { DEFECTS IN WOVEN FABRICS AND THEIR } \\
\text { POSSIBLE CAUSES [30] }\end{array}$} \\
\hline & Defect name & $\begin{array}{c}\text { Possible cause } \\
\text { of defect/Name } \\
\text { of Process }\end{array}$ \\
\hline \multirow{8}{*}{$\begin{array}{l}\text { Weft } \\
\text { defects }\end{array}$} & $\begin{array}{l}\text { Double wefts half width } \\
\text { or less }\end{array}$ & Weaving \\
\hline & Full-width Broken weft & Weaving/Spinning \\
\hline & Half-width broken weft & Spinning \\
\hline & Stop mark & Weaving/Spinning \\
\hline & Fiber in color & Spinning \\
\hline & Soiled-greased weft & Spinning \\
\hline & Thick-thin weft & Spinning \\
\hline & Excessive weft density & Weaving/Spinning \\
\hline \multirow{8}{*}{$\begin{array}{l}\text { Warp } \\
\text { defects }\end{array}$} & Broken warp & Weaving/Spinning \\
\hline & Excessive warp density & Weaving \\
\hline & Loose-tight warp & Weaving \\
\hline & Warp fiber in color & Weaving/Spinning \\
\hline & Soiled-greased warp & Weaving/Spinning \\
\hline & Thin-thick warp & Spinning \\
\hline & Double warps & Weaving \\
\hline & Missing warp & Weaving \\
\hline \multirow{3}{*}{ Others } & Slob & Weaving \\
\hline & Knot & Spinning \\
\hline & Soil/grease stain & Finishing \\
\hline
\end{tabular}






a

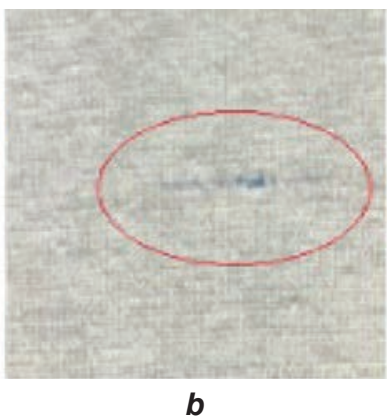

b

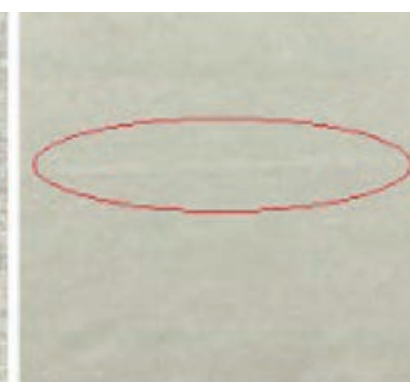

c
Fig. 2. Defects commonly found in recycled fabrics: $a$ - half-width weft; $b$ - fiber in color; $c$ - thin thick weft

bales are inspected with eye and graded according to color catalogue [33]. The first step of so-called rag pulling process, which is a mechanical fiber opening process, is sorting. This step is carried out generally manually, and presence of fibers in different colors in bales leads to this defect.

The number of defects and defect lengths which are necessary for calculating the

thin-thick weft and knot defects are also caused during fiber production. These defects may be caused by fiber opening machine settings and fiber properties. If the cylinder opening, among machine settings, is increased then feed back amount increases. On the other hand, if this opening is decreased, then the clippings cannot be fully transformed into fibers and neps occur [33]. The fiber in color defect obtained in this study is specific to recycled yarns. The clippings which are received to recycled yarn spinning mills as penalty points according to Graniteville 78 system for fabrics are six different weft threads and the length of each is $350 \mathrm{~m}$. These data are shown in table 4 for 100 r-Cotton and 100\% Cotton, 35\% PES - 65\% r-Cotton, 35\% PES - 65\% Cotton, 50\% PES - 50\% $r$-Cotton and 50\% PES - 50\% Cotton fabrics.

As the defects like stains, which do not cause the fabric to be sorted as the second quality for the apparel manufacturing process, Graniteville 78 system does not give points to such defects, which are

Table 4

\begin{tabular}{|c|c|c|c|c|c|c|}
\hline \multicolumn{7}{|c|}{$\begin{array}{c}\text { TOTAL PENALTY POINTS CALCULATED ACCORDING TO GRANITEVILLE78 SYSTEM AND SORTING } \\
\text { OF THE FABRIC ROLLS }\end{array}$} \\
\hline \multirow[b]{2}{*}{ Defect name } & \multicolumn{6}{|c|}{ Number of defects } \\
\hline & $\begin{array}{l}100 \% \\
\text { r-Cotton }\end{array}$ & $\begin{array}{l}100 \% \\
\text { Cotton }\end{array}$ & \begin{tabular}{|l|}
$35 \%$ PES - \\
$65 \%$ r-Cotton
\end{tabular} & $\begin{array}{l}35 \% \text { PES - } \\
65 \% \text { Cotton }\end{array}$ & \begin{tabular}{|l|}
$50 \%$ PES - \\
$50 \%$ r-Cotton
\end{tabular} & $\begin{array}{l}50 \% \text { PES - } \\
50 \% \text { Cotton }\end{array}$ \\
\hline Full-width double wefts & 4 & 4 & 5 & 4 & 3 & 3 \\
\hline Double wefts half width or less & 4 & 2 & 3 & 2 & 2 & \\
\hline Full-width broken weft & 1 & & & & & \\
\hline Half-width broken weft & 9 & 4 & 6 & 2 & 6 & 3 \\
\hline Stop mark & 5 & 3 & 4 & 3 & 4 & 4 \\
\hline Fiber in color & 4 & & 4 & 1 & 1 & \\
\hline Soiled - greased weft & 3 & & & 3 & & \\
\hline Thin thick weft & 5 & & 4 & & & 3 \\
\hline Excessive weft density & & 2 & & & & \\
\hline Broken warp & 5 & 5 & 4 & 4 & 1 & 4 \\
\hline Excessive warp density & & & & 1 & 1 & \\
\hline Loose-tight warp & 2 & & & & & \\
\hline Warp fiber in color & & & 1 & & & \\
\hline Soiled - greased warp & 3 & 1 & & & & 1 \\
\hline Thin thick warp & & 1 & & & & \\
\hline Double warps & & 1 & & & & \\
\hline Missing warp & & 1 & & & & \\
\hline Slub & 2 & & & 1 & 1 & 1 \\
\hline Knot & 6 & 1 & 4 & 1 & 3 & \\
\hline Soil grease stain & 3 & & & 2 & 1 & 2 \\
\hline Number of defects & 56 & 25 & 35 & 24 & 23 & 21 \\
\hline Fabric roll width (inches) & 63 & 63 & 63 & 63 & 63 & 63 \\
\hline Fabric roll length (yards) & 382.8 & 382.8 & 382.8 & 382.8 & 382.8 & 382.8 \\
\hline Total penalty points & 116 & 86 & 100 & 68 & 79 & 63 \\
\hline Evaluation & Accepted & Accepted & Accepted & Accepted & Accepted & Accepted \\
\hline
\end{tabular}






Fig. 3. The number of defects and penalty points calculated according to Graniteville 78 system

not considered as potential threats. Accordingly, defects, which have been noticed during fabric inspection that can be removed in the apparel manufacturing processes, were not given points. These defects are fiber in color, slub, soil/grease stains, soiled-greased warp, and warp fiber in color.

The total penalty points have been found as 115 for the $100 \%$ r-cotton fabric, and 86 for the $100 \%$ cotton fabric. The most common defect for $100 \%$ r-cotton fabric is half-width broken weft, and the second most common one is knot defect.

Total penalty points calculated for $35 \%$ PES - 65\% r-Cotton, and 35\% PES - 65\% Cotton are 100 and 68 , respectively. Half-width broken weft is the most common defect found in 35\% PES - 65\% r-Cotton fabric. However, as the PES yarn contributes to the strength, the frequency of half-width weft defect is lower than that in the $100 \% \mathrm{r}$-Cotton fabric.

Total penalty points calculated for the 50\% PES $50 \%$ r-Cotton fabric and the 50\% PES - 50\% r-Cotton fabric are 79 and 63, in consecutive order. Half-width broken weft is the most common defect in 35\% PES - 65\% r-Cotton fabric. However, as the PES yarn contributes to the strength, the frequency of halfwidth weft is lower than that in the $100 \% \mathrm{r}$-Cotton fabric.

In figure 3, the number of defects and penalty points calculated for all fabrics are graphically illustrated. According to this, the greatest penalty point belongs to the $100 \%$ r-Cotton fabric. In descending order, 100 points for the $35 \%$ PES - 65\% r-Cotton fabric, 86 points for the $100 \%$ Cotton fabric, 79 points for the $50 \%$ PES - 50\% r-Cotton fabric, 68 points for the $35 \%$ PES - 65\% Cotton fabric, 63 points for the $50 \%$ PES - 50\% Cotton fabric were obtained. The increase in PES content in the weft threads led to reduction in number of defects found in the recycled yarns. In table 4 , the number of defects and penalty points calculated for all fabrics are shown.

Accordingly, total penalty points calculated according to Graniteville 78 system and evaluation of the fabric roll are attached to the end of the table. All fabrics were found suitable for apparel manufacturing processes and are accepted.

\section{CONCLUSIONS}

Based on its positive effect on the price and environment, the importance of yarn and fabric production from recycled raw material is growing day by day. Nowadays, numerous producers including H\&M, Levi Strauss \& Company, Adidas, Nike and Timberland are utilizing recycled materials within frames of social responsibility projects. Global firms which produce recycled yarns and fabrics from polyester, nylon and cotton (Repreve $\AA-$-Unifi, Produced by Unifi, Repreve $\AA$, Ecocircle $®$ - Tenjin, Econyl $₫$ - Aquafil) are developing new products and use of recycled yarns and fabrics is becoming more and more common. Similarly, in our country, in Usak, one of the major textile centers, colorful cotton and yarns are produced without using any land, tractors, water, dye or any chemical agents. Second-quality yarns are sold at prices one third of their original counterparts. The clothing wastes collected from different parts of the world and Turkey are brought to Usak. After sorting in terms of color is carried out, cutting process takes place. Then, some of the wastes are transformed into the fiber form via use of rag pulling machines and used in the automotive industry as well as in bed production as felts. On the other hand, the recycled materials, which is transformed in the yarn form, is utilized in home textiles, curtains, clothing, and seat cover production. Hence, these wastes are re-utilized economically while colorful cotton is produced without using any land, tractors, water, dye or other chemicals [34]. Sorting of fabric rolls as the first and second quality is a hard task. Thus, defects that can be found in recycled fabrics are of importance. A fabric roll, which is considered as the first quality by the producer can be found as the second quality by the receiver. Fabric inspection grading systems allow everyone to speak the same language. This study has been conducted in order to determine defects that can be seen on the recycled fabrics prior to apparel manufacturing processes as well as for sorting of the fabric roll. Nevertheless, standardization of quality is needed for recycled yarns. More research study is necessary related to production of higher quality recycled yarns and fabrics more efficiently

\section{ACKNOWLEDGEMENT}

The author acknowledge the employees and directors of CNF Tekstil and Osman Canlı Tekstil who contributed to the experimental work.

\section{REFERENCES}

[1] Hawley, J.M., Economic Impact of Textile Recycling, 2008, Available at: http://krex.kstate.edu/dspace/bitstream/ 2097/1228/1/EconlmpactHawley2008.pdf [Accessed June 15, 2018]

[2] Chen, H., Burns, L.D., Environmental Analysis of Textile Products, In: Clothing and Textile Research Journal, 2006, 24, 3, 248-26

[3] Bayraktar, T., Ecology in Textiles and Apparel Manufacturing, and Ecolabels, ITKİB AR\&GE ve Mevzuat Şubesi, 2005

[4] Güngör, A., Palamutçu, S., İkiz, Y., Cotton Textiles and the Environment: Life Cycle Assessment of a Bathrobe, In: Textile and Apparel, 2009, 19, 3, 197-205 
[5] Lu, J.J., Hamouda, H., Current Status of Fiber Waste Recycling and its Future, In: Advanced Materials Research, 2014, 878, 122-131

[6] Eryuruk, S.H., Greening of the Textile and Clothing Industry, In: Fibres \& Textiles in Eastern Europe, 2012, 20, 6A, 95, 22-27

[7] Gunaydın, G. K., Can, Ö., A research on Tensile Properties of Vortex Yarns, In: Industria Textila, 2017, 68, 3, 170-175, https://doi.org/10.35530/IT.068.03.1401

[8] Merati, A.A., Okamura, M., Producing Medium Count Yarns from Recycled Fibers with Fiction Spinning, In: Text. Res. J., 2004, 74, 7, 640-645

[9] Wulfhorst, B., Textile Technology, Translation; Demir A., Torun A.R., İstanbul, 2003, 295-300

[10] Vadicherla, T., Saravanan, D., Textiles and Apparel Development Using Recycled and Reclaimed Fibers, In: Muthu S. (eds) Roadmap to Sustainable Textiles and Clothing. Textile Science and Clothing Technology, Springer, Singapore, 2014

[11] Leonas, K.K., The Use of Recycled Fibers in Fashion and Home Products, In: Muthu S. (eds.) Textiles and Clothing Sustainability. Textile Science and Clothing Technology, Springer, Singapore, 2017

[12] Rathinamoorthy, R., Sustainable Apparel Production from Recycled Fabric Waste, In: Muthu S. (eds.) Sustainable Innovations in Recycled Textiles. Textile Science and Clothing Technology, Springer, Singapore, 2018

[13] Haule, L..V, Carr, C.M., Rigout, M., Preparation and Physical Properties of Regenerated Cellulose Fibres from Cotton Waste Garments, In: Journal of Cleaner Production, 2016, 112, 5, 4445-4451

[14] Haule, L.V., Carr, C.M., Rigout, M., Investigation into the Supramolecular Properties of Fibres Regenerated from Cotton Based Waste Garments, In: Carbohydr Polym, 2016, 144, 131-139

[15] Umar, M., Shaker, K., Ahmad, S., Nawab, Y., Umair, M., Maqsood, M., Investigating the Mechanical Behavior of Composites Made from Textile Industry Waste, In: The Journal of The Textile Institute, 2017, 108, 5, 835-839

[16] Silva, R., Byrne, N., Utilization of Cotton Waste for Regenerated Cellulose fibres: Influence of Degree of Polymerization on Mechanical Properties, In: Carbohydrate Polymers, 2017, 174, 89-94

[17] Inoue, M., Yamamoto, S., Performance and Durability of Woven Fabrics Including Recycled Polyester Fibers, In: Journal of Textile Engineering, 2004, 50, 2, 25-30

[18] Larney, M., Van Aardt, A.M, Case study: Apparel Industry Waste Management: A Focus on Recycling In South Africa, In: Waste Management \& Research, 2010, 28, 36-43

[19] Zoua, Y., Reddya, N., Yang, Y., Reusing Polyester/Cotton Blend Fabrics for Composites, In: Composites Part B: Engineering, 2011, 42, 4, 4, 763-770

[20] Béchir, W., Mohamed, B.H., Béchir, A., Industrial Cotton Waste: Recycling, Reclaimed Fiber Behavıor And Quality Prediction of Its Blend, In: Textile and Apparel, 2018, 28, 1, 14-20

[21] Duru, P.N., Babaarslan, O., Determining an Optimum Opening Roller Speed for Spinning Polyester/Waste Blend Rotor Yarns, In: Textile Research Journal, 2003, 73, 10, 907-911

[22] El-Nouby, G.M., Hairiness of Yarns Made of Recycled Waste Fabric, In: J. Appl. Sci. Res., 2007, 3, 10, 972-976

[23] Halimi, T.M., Ben Hassen, M., Azzouz, B., Sakli, F., Effect of Cotton Waste and Spinning Parameters on Rotor Yarn Quality, In: Journal of The Textile Institute, 2007, 98, 437-442

[24] Kaplan, S., Göktepe, Ö., Investigation into Navel Selection for Rotor Spinning Machine Using Cotton Waste, In: Fibres \& Textiles in Eastern Europe, 2006, 14, 3, 58-62

[25] Béchir, W., Béchir, A., Mohamed, B.H., Recycling of Post-industrial Cotton wastes: Quality and Rotor Spinning of Reclaimed Fibers, In: International Journal of Advanced Research, 2015, 3, 6, 94-103

[26] El-Nouby, G.M., Recycled Yarn from Textile Waste - Part I: Recycled Yarn Hairiness, In: Egy. J. Text. \& Polym. Sci. \& Tech., 2006, 11

[27] Hasani, H., Semnani, D., Tabatabaei, S, Determining the Optimum Spinning Conditions to Produce the Rotor Yarns from Cotton Wastes, In: Industria textilă, 2010, 61, 6, 259-264

[28] Ala, D.M., İkiz, Y., Defect Detection of Velvet Bathrobe Fabrics and Grading with Demerit Point Systems, In: Pamukkale University Journal of Engineering Sciences, 2015, 21, 7, 288-295

[29] Dülgeroğlu, K.Ö., A Statistical Quality Control System in a Medium-Scale Weaving Mill: I. Control of Fabric Defects, In: Pamukkale University Journal of Engineering Sciences, 2010, 16, 3, 291-301

[30] Turkish Standards Institute, Definition and Terminology Relating to Woven Fabric Defects, Ankara, Türkiye, TS 471 ISO 8498, 2005

[31] Gürarda, A., Investigation The Relationship Between Fabric Properties And Clothing Process, In: Journals of Textiles and Engineer, 2015, 22, 99, 41-50

[32] ASTM D5430-13, Standard Test Methods for Visually Inspecting and Grading Fabric

[33] http://www.yuksel.com.tr/index2.html [Accessed May 13, 2018]

[34] http://www.milliyet.com.tr/turkiye-nin-tekstil-atigi-usak-ta-iplige-usak-yerelhaber-2339877/ [Accessed May 13, 2018]

\section{Author:}

\section{KALKANCI MIHRIBAN}

Pamukkale University, Denizli Vocational School of Technical Sciences,

Camlaraltı Mah. Fakülte Cad., no. 30, 20160, Kınıkı/Denizli, Turkey

Corresponding author:

KALKANCI MIHRIBAN

e-mail: mkalkanci@pau.edu.tr 


\section{AHP analysis of organizational culture in textile companies in Serbia}

DOI: 10.35530/IT.071.02.1588

SLAVICA MILETIĆ

ŠIMŠIĆ ZDENKA STANOJEVIĆ

IVAN JOVANOVIĆ

MILAN RADIVOJEVIĆ

VESNA CONIĆ

\section{ABSTRACT - REZUMAT}

\section{AHP analysis of organizational culture in textile companies in Serbia}

Organizational culture has attracted attention in research, as it affects not only the performance of employees, but also the overall efficiency and sustainability of the entire organization.

An analysis of the organizational culture in textile companies is a problem that can be solved using the multi-criteria decision-making method (MCDM). The interest in analyzing organizational culture comes from the fact that culture influences the behavior of members of the organization, decision-making and the setting of strategic goals. Companies can confront the challenges in nowdays by choosing a strong and stable organizational culture. An approach based on the AHP method is proposed to solve this complex problem in this paper. The AHP method is convinient for organizational culture analysing by Hofsted's dimensions of national culture and determining the severity of the criteria.

The usability and effectiveness of the AHP approach has been considered in the empirical application of the proposed method for selecting an organizational culture in textile companies in Serbia.

Keywords: AHP method, efficiency, innovation, performance of employees, strategic goals, textile products

\section{Analiza AHP a culturii organizaţionale în companiile textile din Serbia}

Cultura organizațională a atras atenția cercetării, deoarece influențează nu numai performanța angajaților, ci și eficiența generală și sustenabilitatea întregii organizații.

O analiză a culturii organizaționale în companiile textile este o problemă care poate fi rezolvată folosind metoda de luare a deciziilor cu mai multe criterii (MCDM). Interesul pentru analiza culturii organizaționale vine din faptul că aceasta influențează comportamentul membrilor organizației, luarea deciziilor și stabilirea obiectivelor strategice. Companiile se confruntă cu provocările actuale, alegând o cultură organizațională puternică și stabilă. În această lucrare, se propune o abordare bazată pe metoda AHP, pentru a rezolva această problemă complexă. Metoda AHP este aplicabilă pentru cultura organizațională, analizând dimensiunile Hofsted ale culturii naționale și determinând importanța criteriilor.

Utilitatea și eficacitatea abordării AHP au fost demonstrate prin aplicarea empirică a metodei propuse pentru selectarea unei culturi organizaționale, în companiile textile din Serbia.

Cuvinte cheie: metoda AHP, eficiență, inovare, performanța angajaților, obiective strategice, produse textile

\section{INTRODUCTION}

The textile industry represents an important branch of the processing industry and is significant for the economy of a country. According to the type of products, this branch of industry belongs to the light industry. The textile industry in Serbia has a long tradition and is one of the most important branches of the processing industry. Since the biggest export and import of textile products is realized with the European Union, it shows that Serbia is facing the European market [1]. In order to win in the chosen market and achieve their strategic goals, textile companies have to choose the culture, skills, processes and technology that will support them [2]. The interest in organizational culture stems from the belief that culture influences behaviour, decision-making, organizational strategy, individual motivation, and organizational performance [3]. Strong organizational culture ensures stability of the organization, has a positive impact on the motivation of employees and their loyalty, creates conditions for better coordination and control of the organization, creates conditions for innovation, improves creativity and reduces conflicts [3-5]. For some organizations, organizational culture can be a major obstacle to change. Each organization has its own culture that depends on its strength, which can significantly affect the attitudes and behaviours of the employees' organization [6]. The organizational culture of textile companies in Serbia refers to the system of the meaning of its employees and differs from other organizations. It is a matter of encouraging employees to innovate, create teams, orientations, competition, precision, stability, motivation, communication, stakeholder satisfaction, customer-oriented market and over-risk. These characteristics take on the essence of the cultural organization of the textile companies, give a complex picture of their culture and evaluate the work and behaviour of the organization [6]. Global organizations have to consider cultural differences carefully in all countries to determine which management practices are most likely to be most effective in different employee populations [7]. 
In an effort to help the textile companies' management to increase productivity, an analysis of the organizational culture was made using Hofstede's dimensions of national culture. Hofstede's dimensions as a framework of national culture can be used to better understand organizational culture in textile companies.

Organizational culture improves: coordination and motivation of employees; defines interpersonal relations; style of leadership and reduces the number of employees' conflicts in the organization [8-9]. The modern way of operating in business requires of professional managers to implement the true organizational culture. Organizational culture essentially depends on the leader, the motivation of the employees and the satisfaction of the stakeholders. It can be defined as a system of values, norms, assumptions and attitudes that are manifested through various synapses that the established organizations have established and adopted through their shared experience, which helps them define the meaning of the outside world and the ways in which they work with it [6].

Organizational culture is known as a key component of knowledge managing and organizational learning, and it has been established that national culture significantly influence on it [10]. We adopt an organizational culture on an already acquired formed culture. When we become part of the working organization, then we socialize according to the practice of the organization where we are employed [11]. An organizational culture is influenced by patterns of belief, value and experience, developed through the organization's history that manifests itself through material objects, as well as the behaviour of members of the organization [12]. Organizational culture is shaped according to the frequent fluctuation of employees and their acquired values. With the change of organizational culture, the structure of the organization is also changing because they are mutual connected. Employees are changing when a manager or leader models his desired behaviour. The change in organizational culture and structure occurs when the manager or leader demonstrates and reinforces the desired model [13]. Each organization owns and develops its specific culture because it is built from different people [12]. The culture of an organization is constantly changing and begins to adapt to the stakeholders due to their active influence in decision-making boards and resolving concerns textile companies [14-16]. Culture represents common values, motives, beliefs, identities and interpretations, that is, the significance of important events stemming from the shared experiences of employees who are transmitted to generations [17].

The aim of this paper is to provide an efficient multicriterial decision-making model (MCDM) for choosing an organizational culture using Hofstede's dimensions that are frameworks for developing differentiated hypotheses in multicultural organizational studies. The MCDM model is based on the application of the AHP method. MCDM methods are rapidly evolving in the direction of methodology to solve real problems and have considerable attention of researchers from different fields [18-24].

\section{EXPERIMENTAL PART}

Nowadays, the largest and most influential research among intercultural research programs is carried out by the organization Global Leadership and Organizational Behavior Effectiveness (GLOBE) led by Robert House of the University of Pennsylvania, which was created with the already classical study of Geert Hofstede $[25,10]$.

The authors of the GLOBE project have identified the existence of significant differences among Western (Nordic Europe, Germanic, Latin America, Anglo clusters and Latin America) and eastern clusters (Eastern Europe, Confucius Asia, South Asia, the Middle East and Subsahar Africa) [26]. Their research shows that our national culture can be classified as a cluster of Eastern Europe. Researches have shown that organizational culture in companies in Serbia is "somewhere between" the western and eastern clusters [27].

According to Hofstede, the "national culture" of a society is common to individuals and all those in that society, but it differs from another society. The author distinguishes the national culture on the basis of four dimensions and later added the fifth: power distance, individualism-collectivism (inuvidualism-collectivizm), masculinity-femininity, avoidance of uncertainty and fifth, short-term and long-term perspective (shot term-long term). Also, there are other qualifications of the dimensions of national culture, which can be used as basic research, but these are most commonly used and the others are less present in the literature [28-32].

In the paper, the chosen dimensions of the optimal model of organizational culture are used as the framework for developing differentiated hypotheses in multicultural organizational studies. Undeveloped countries possess a collectivist culture with a high power distance, while developed have an individual culture with a low power distance. According to Hofstede's analysis, Serbian culture consists of the following dimensions: a great distance of power, a high degree of avoidance of uncertainty, collectivism and women's values, and by its characteristics the closest to the countries of Latin America. Table 1 shows a comparative overview of the national and organizational cultures.

High power distances (Alternative 1): the distance of power is focused so that "the level in which the less powerful members of an organization accept the fact that power is not evenly distributed" [10]. There are very powerful individuals and groups in society, so that members of one national culture consider this phenomenon normal, that power is not evenly distributed. The high distance of power in organizations among employees means that the state is natural and normal. Those who have the power must constantly prove it, if in some cases it is shared with 


\begin{tabular}{|l|c|c|c|c|c|c|}
\hline \multicolumn{6}{|c|}{ COMPARATIVE OVERVIEW OF THE NATIONAL AND ORGANIZATIONAL CULTURES [10] } \\
\hline Model dimensions & $\begin{array}{c}\text { Serbian } \\
\text { Cultures }\end{array}$ & $\begin{array}{c}\text { Anglosakson } \\
\text { Cultures }\end{array}$ & $\begin{array}{c}\text { German } \\
\text { Cultures }\end{array}$ & $\begin{array}{c}\text { Skandinavian } \\
\text { Cultures }\end{array}$ & $\begin{array}{c}\text { Latino-European } \\
\text { Cultures }\end{array}$ & $\begin{array}{c}\text { Latino-American } \\
\text { Cultures }\end{array}$ \\
\hline Distance of Power & 76 & 37.5 & 22.5 & 31 & 59 & 81 \\
\hline Uncertainty Avoidance & 88 & 40.5 & 67.5 & 39.5 & 80.5 & 79 \\
\hline Individualism & 27 & 90 & 61 & 70 & 73.5 & 21 \\
\hline Mens Value & 21 & 64 & 72.5 & 6.5 & 56.5 & 71 \\
\hline
\end{tabular}

someone, it is a sign of weakness and not of strength. Those who have the power in this dimension themselves decide on everything so that the autocratic style of leadership is emphasized (India, France, Panama, Brazil).

Low power distribution (Alternative 2): With this alternative, as opposed to the previous alternative (A1), there is a growing awareness that power should be equally distributed. All members of a society or organization have evenly or equal power. There are cooperative relationships between the decision makers (managers) and employees. Employees are involved in the decision-making process. Unequal distribution of power is considered undesirable (Austria, Denmark, New Zealand).

High degree of avoidance of uncertainty (Alternative 3 ): Avoidance of uncertainty is "the degree to which members of a some culture feel threatened in unclear or unknown situations" [10]. In national cultures with a high degree of avoidance of uncertainty, employees are not ready for change, risk and uncertainty. Changes are treated as a threat to the prospect of prosperity. The degree of tolerance with a high avoidance of uncertainty for change is very low; clear organizational structure with defined rules; decisions are made on the basis of facts collected from different sources. (Japan, Portugal, Greece).

Low degree of avoidance of uncertainty (Alternative 4): National cultures with a low degree of avoidance of uncertainty easily tolerate changes, uncertainties and unknown situations. They see changes as a chance rather than a threat. The degree of tolerance with low avoidance of uncertainty towards different changes is very high, employees take the risk without special rules (Denmark, UK, USA).

Collectivism (Alternative 5): A national culture that has the dimension of collectivism is focused on people who have been integrated since their birth into powerful, cohesive groups where they care for the whole society throughout their lifetime in exchange for irreversible loyalty [10]. Collective national cultures nourish the values of respect, security, control, harmony and the ability to understand [33]. In collectivist cultures, identity is based on a social system, collectivism. Leaders are more committed to meeting the needs of other stakeholders than to their needs [34]. Employees are those who accept standards and team perform their obligations for the benefit of the collective as a whole (Pakistan, Panama, China).
Induvidualism (Alternative 6): With this alternative, the national culture refers to loose relationships in a society where everyone is expected to care for herself and to his, that means the indentity is based on the individual (USA, UK, Australia). In indivudualistic national cultures, people rely primarily on their own ideas and attitudes [35]. Decisions are made before a detailed consideration of facts, strategic planning is not a primacy as in collectivistic cultures where problems are analyzed, but on executive leadership [36]. Women's values (Alternative 7): These dimensions bring a different dimension than men's value, their gender roles are interweave, both are directed, caring towards others and most importantly they are interested in quality of life and environmental protection [10]. When making decisions, they use the collected information, the decisions are based on facts (Switzerland, New Zealand).

Male values (Alternative 8): The male value dimension is focused on a clear division of gender roles, women are moderate and not rough, they are interested in a quality life, while men are aggressive, strong and focus on material success. In the decision-making process they rely more on their intuition than on the facts. (Japan, Austria).

Long-term orientation (Alternative 9): Long-term orientation refers to deegree of culture in which culture inspire of its members to accept the delayed satisfaction of their material, social and emotional needs [10]. The long-term orientation dimension is the motivation of employees to be oriented towards future rewards, that is, to be persistent and economical (China, Japan).

Short-term orientation (Alternative 10): the dimension of short-term orientation focuses on the past and the present, i.e. respect of the tradition "keeping the face and fulfilling social obligations" [10]. (Great Britain, USA, Germany, Austria).

Defined criteria by decision makers (expert team) are: The possibility of effective implementation of strong organizational culture (criterion $\mathrm{C}_{1}$ ), change of paradigm in business environment (criterion $\mathrm{C}_{2}$ ), planning efficiency and managing (criterion $\mathrm{C}_{3}$ ), maximization of profit (criterion $\mathrm{C}_{4}$ ), functioning of the company (criterion $\mathrm{C}_{5}$ ), employee antagonism (criterion $\mathrm{C}_{6}$ ) and Innovation at work (criterion $\mathrm{C}_{7}$ ). Criteria are the measures by which alternatives (dimensions) are identified from the same point of view. The 
Criterium Decision Plus software was used for the budget.

In the following text there are presented criterums and their weight coefficients.

Criterion $1\left(\mathrm{C}_{1}\right)$ : Possibility of effective implementation of the strong organizational culture: The criterion of the possibilities of effective implementation of the strong organizational culture is very important for raising the awareness of all stakeholders, starting with employees, managers, suppliers, banks, shareholders and customers. Increased perception for the implementation of the optimal model of organizational culture comes to a competitive textile company, to penetration and market diversification.

Criterion $2\left(\mathrm{C}_{2}\right)$ : Changing the paradigm in the business environment: This criterion involves a new way of thinking, the perception of understanding the world in which we work and live. It is associated with changes in products, technology and managerial techniques. Born new economic and social relations emanate from the principles of business ethics, corporate social responsibility, sustainable development and the quality of products and services.

Criterion $3 \quad\left(\mathrm{C}_{3}\right)$ : Efficiency of Planning and Management: This criterion has a special role in the organization for planning and management.

Increases the satisfaction of all stakeholders: employees, managers, leaders, stakeholders, customers, consumers, banks, etc. leads to more efficient business, thus providing the company competitive advantage and connection to a successful global business. This criterion leads to efficiency in the international environment and to the sustainable business of modern textile companies.

Criterion $4\left(\mathrm{C}_{4}\right)$ : Profit maximization: The criterion profit maximization is one of the most important criteria. Maximizing the profit of organizations becomes: solvent, liquid, competitive and strong organization. The level of satisfaction is increase for the employees and perception of security and become more motivated. With the maximization of profit, the organization develops and grows, develops new products, modifies managerial techniques, becomes multinational companies, engages in international business, into the world trade system, increases product quality and reduces product prices.

Criterion $5\left(\mathrm{C}_{5}\right)$ : Functionality of company: This criterion determines exactly the goals of the company in other words business activity. Within the company, processes are carried out related to the performance of tasks necessary for the functioning of the entire system. It is important for all stakeholders to function the company because its closedown would lead to major problems. Employees would lose their jobs, the number of unemployed would increase, the economy would be at a loss and one branch would be extinguished, depending on the activity of the company. Today in modern global business, survivals of companies are strategic decisions focused on the stealing of stakeholders. Efficient and effective functioning is reflected on the quality of products and services, in order to satisfy all the interested parties (stakeholders).

Criterion $6 \quad\left(\mathrm{C}_{6}\right)$ : Counterwork of employees: Counterwork which appearing among the employees can cause the consequences of uncertainty about how the fate of individuals, organization and their common future will be. Counterwork of employees most often provides frequent changes, but they should not be a surprise. If the changes are positive employees provide counterwork, they want to maintain the same condition. Fear of moving into something new that brings globalization into the future creates enormous stress among employees and managers and if the current situation in the organization is unbearable. For this criterion there are two visible phenomena: perception and threat.

Criterion $7\left(\mathrm{C}_{7}\right)$ : Innovation at work: Introducing innovation at work is a very important criterion not only for employees but also for the image of an organization. Thus, the introduction of innovation at work can save time and money, bring competitive advantage and development. Innovative companies easily accept changes, create more efficient processes, produce ideas, have greater productivity, gain greater success, grow and adapt to the market. They introduce innovative thinking, creative problem solving, operational task determination and perception for an innovative sustainable culture. So, it can be considered that innovation is the key of success for textiles' companies, just as in other economic field [37].

The AHP method analyzes Hofsted's dimensions as offered alternatives: high distance of power, low distance of power, high degree of avoidance of uncertainty, low degree of uncertainty, collectivism, induvidualism, female and male values.

The analytical hierarchical process (AHP) is a quantitative technique that allows the structuring of a complex decision-making problem with multiple criteria and provides an objective methodology that applies to a wide range of decisions. Thomas Saaty is the creator of this method, in the original name of the Analytic Hierarchy Process and presents powerful tool for the decision maker in variants with more alternatives [38]. The first step is to define a multi-dimensional hierarchical structure of goals, criteria, and alternatives [39]. Further step is, determination of the weight coefficients of the criteria, using the scale of comparison given in table 2 .

In table 3 is presented the results of comparison.

\begin{tabular}{|l|c|}
\hline \multicolumn{2}{|c|}{ DOMINANCE } \\
\hline \multicolumn{2}{|c|}{ Description 2} \\
\hline Equally & Rating \\
\hline Poor domination & 1 \\
\hline Strong domination & 3 \\
\hline Very strong domination & 5 \\
\hline Absolute domination & 7 \\
\hline $2,4,6,8$ are intermediate values & 9 \\
\hline
\end{tabular}




\begin{tabular}{|l|c|c|c|c|c|c|c|}
\hline \multicolumn{10}{|c|}{ COMPARATIVE RESULTS } \\
\hline \multicolumn{1}{|c|}{ Criteria } & $\mathbf{C}_{\mathbf{1}}$ & $\mathbf{C}_{\mathbf{2}}$ & $\mathbf{C}_{\mathbf{3}}$ & $\mathbf{C}_{\mathbf{4}}$ & $\mathbf{C}_{\mathbf{5}}$ & $\mathbf{C}_{\mathbf{6}}$ & $\mathbf{C}_{\mathbf{7}}$ \\
\hline Weighting coefficients criteria & 0.072 & 0.109 & 0.127 & 0.243 & 0.140 & 0.037 & 0.271 \\
\hline Consistency coefficient & \multicolumn{10}{|c|}{0.046} \\
\hline
\end{tabular}

\section{RESULTS AND DISCUSSION}

Obtained results of the ranking alternatives are shown in table 4.

The results of the ranking of the criteria (table 3 ) show that the $\mathrm{C} 7$ criterion (innovation at work) has the greatest impact on the result of the selection because its coefficient is 0.271 . It affects $27.1 \%$ on the result of choosing an optimal model of organizational culture. Innovation improves sustainability performance [40]. Common in strategies in all OCED countries (Organization for Economic Co-operation and Development), is to rely on the belief that innovation involves improving competitiveness and growth. There is an opinion that without innovation there will be no sustainability [41-42]. Future competitiveness is no longer defined as a struggle to keep the organization competitive in existing markets, but rather to open up new markets based on innovation [43].

Table 4

RESULTS OF THE RANKING ALTERNATIVES

\begin{tabular}{|c|l|c|}
\hline No. & \multicolumn{1}{|l|}{ Dimension of national culture } & Result \\
\hline 1 & A5 (colectivism) & 0.149 \\
\hline 2 & A9 (long-term orientation) & 0.148 \\
\hline 3 & A2 (low distance of power) & 0.137 \\
\hline 4 & A7 (womens value) & 0.107 \\
\hline 5 & $\begin{array}{l}\text { A4 (low degree of avoidance of } \\
\text { uncertainty) }\end{array}$ & 0.094 \\
\hline 6 & A10 (short-term orientation) & 0.089 \\
\hline 7 & A1 (high distance of power) & 0.082 \\
\hline 8 & A8 (male values) & 0.073 \\
\hline 9 & A6 (individualism) & 0.065 \\
\hline 10 & A3 (a high degree of uncertainty) & 0.057 \\
\hline
\end{tabular}

On the second place it is the $\mathrm{C} 4$ criterion (profit maximization) which has $24.3 \%$ of the impact on the result of the selection because its weight coefficient is 0.243 . Maximization of profit brings satisfaction of stakeholders and creating a model of sustainable companies.

On third place it is the criterion $\mathrm{C} 5$ (functioning of the company) with a weight coefficient of 0.14 that affects $14 \%$. The functioning of textile companies is important for the survival of the stakeholders.

On the fourth place it is the $\mathrm{C} 3$ criterion (planning and management efficiency), where the weight coefficient is 0.127 . It affects $12.7 \%$ on the ranking of the alternative. Effective planning and managing leads to the implementation of a sustainable business model, improving the performances and competitiveness of textile companies.

On the fifth place it is the criterion C2 (change of the paradigm in business), with a weight coefficient of 0.109 , which means that $10.9 \%$ influence the choice of the optimal model of organizational culture. Criterion C2 creates guidelines for changing business systems for responsible and sustainable textile companies.

On the sixth place it is $\mathrm{C} 1$ (the possibility of effective implementation of the strong organizational culture), with a weight coefficient of 0.072 . It means that with $7.2 \%$ affects the choice of organizational culture. The concept of all stakeholders is to contribute to the development of corporate mananing by using an optimal model of organizationla culture.

On the seventh place it is criterion C6 (employee antagonism) which influences the choice of the optimal model with $3.7 \%$ because the weight coefficient is 0.037 . Employees provide antagonism, do not want to change the existing situation, their lack is the low perception of creating an optimal culture.

In analyzing the Hofstede dimensions of national culture, it starts from the optimal (best) alternative. It is an alternative to $\mathrm{A} 5$ (colectivism). For textile companies, this dimension has the highest value because its result is 0.149 . The reason is that this dimension fosters values: respect, security, control, harmony and the ability to understand all stakeholders. Leaders are dedicated to meeting the needs of other stakeholders. Employees are those who accept and perform business obligations for the purpose of sustainable business (Pakistan, Panama, China).

On the second place it is the dimension of long-term orientation, alternative A9 with a score of 0.148 . Employees are oriented towards perseverance, resilience and future rewards (China and Japan).

On the third place it is a low distance of power with a score of 0.137 . With this dimension all members of the organization should have equal power, there are cooperative relationships between employees and managers. Employees are involved in planning and management that positively affect textile companies. (Austria, Denmark, New Zealand).

On the fourth place it is the cultural dimension of women's value with a score of 0.107 . Characteristics of this dimension are reflected that the employees are focused and caring towards each other and are interested in quality of life. Factual facts-based information (Switzerland, New Zealand) are used in planning and managing. 
On the fifth place, the dimension is a low degree of avoidance of uncertainty with a score of 0.094 . Employees of textile companies are more likely to submit changes, uncertainty, accept the risk, and the degree of tolerance is very high. They accept changes as a chance rather than risk (Denmark, United Kingdom, USA).

\section{CONCLUSIONS}

Based on the facts given in the literature, the authors analyzed the organizational culture of the textile companies in Serbia by the AHP method using Hofsted's dimensions.

The proposed method (AHP) can help decision-makers to easily choose and analyze factors and attributes. The strengths of this approach over the existing methods are in minimizing the objectivism of the decision-makers, better evaluation of different criteria and alternatives, better consistency of the obtained results, etc.

Organization managers in textile companies have to consider cultural differences carefully in order to determine which management and survival practices are most effective. Researches show that the culture of the textile companies consists of the following dimensions of the national culture:

- On the first place it is the alternative A5, the collectivism that has the highest value (0149). This dimension fosters the value of respect, security, control, harmony, and the ability to understand all the interested parties (states, banks, trade unions, managers, leaders, users, suppliers and employees).

- On the second place it is the alternative A9, a longterm orientation towards perseverance, saving and future rewards.

- On the third place it is alternative A2, a low distance of power characterized by cooperative relations between employees and managers.

- On the forth place, the analysis shows that alternative $A 7$, a woman's value that keeps employees focused and caring for each other and interested in the quality of life.

- On the fifth place it is the alternative A4, the low degree of avoidance of uncertainty, which charac- teristics give employees the ability to make changes easier, accept the risk, the degree of tolerance is very high, so that changes are accepted as a chance rather than a risk.

Criterion C7 (Innovation at Work) has the greatest impact on the choice of the organizational culture of textile and other companies. The weight coefficient of this criterion has the highest value that is 0.272 and has the greatest influence on the analysis of the results, ie the choice of alternatives. The criterion $\mathrm{C} 4$ (Profit maximization) with a weight coefficient of 0.243 is second in importance.

Innovation at work (Criteria C7) and profit maximization (criteria C4) contribute to the development of new markets, products and services. These elements with maximal weight are fundamental for the planning of further activities in the textile industry.

Employees in textile companies have to be more agile, more flexible, and more capable to monitor market niches. In order to support this kind of activity, it is important to establish genuine internal cultures. Textile companies that want to operate more productively, improve their sustainability, operate in a modern way and successfully achieve strategic goals, have to change their culture.

So research and changes in organizational culture as well as the way to succeed in this, are great issues for other researchers.

The proposed model has only been implemented in textile companies in Serbia, where their managements have found the proposed model satisfactory and implementable but described model can be implemented in many different fields of industry. Implementation of the obtained results enables the involvement of the Serbian industry abroad.

\section{ACKNOWLEDGEMENTS}

Research was funded by the Ministry of Science and Technological Development Republic of Serbia as part of the project TR 33023 and TR34004: Development of the technology of flotation concentration of copper and precious metals in order to achieve better technological results and Development ecological and energetically efficiently technologies for obtaining base and pressure metals by combination bioleaching solvent extraction and electro winning and refining.

\section{REFERENCES}

[1] Petrović, G., Urošević, S., Karabašević, D., Maksimović, M., Stanje i perspektive razvoja tekstilne industrije u Srbiji, In: Tekstilna Industrija, 2017, 3, 4-8

[2] Hopwood, P., Tracking the trends 2017, The top 10 trends mining companies will face in the coming year, Mining Deloitte Touche Tohmatsu Limited, 2017

[3] Thokozani, S.B., Strong vs.Weak Organizational Culture: Assessing the Impact on Employee Motivation, In: Arabian Journal of Business and Management Review, 2017, 7, 287

[4] Körner, M., Wirtz, M.A., Bengel, J., Göritz, A.S., Relationship of Organizational Culture, Teamwork and Job Satisfaction in Interprofessional Teams, In: BMC Health Services Research, 2015, 15, 1, 243

[5] O'Neill, J.W., Beauvais, L.L., Scholl, R.W., The Use of Organizational Culture and Structure to Guide Strategic Behavior: An Information Processing Perspective, In: Journal of Behavioral and Applied Management, 2016, 2, 2, 131-149

[6] Robbins, S.P., Judge, T.A., Organizational Behavior, 15th Eden, CHAPTER 16 Organizational Culture, 2013

industuia textilă — $129 \mid$ 2020, vol. 71, no. 2 
[7] Kim, Y., Cohen, D., Au, W., The Jury and Abjury of My Peers: The Self in Face and Dignity Cultures, In: Journal of Personality and Social Psychology , 2010, 98, 6, 904-916

[8] Nazarian, A., Atkinson, P., Impact of Culture on Leadership Style: The Case of Iranian Organisations, In: World Applied Sciences Journal, 2013, 28, 6, 770-777

[9] Lok, P., Crawford, J., The Effect of Organisational Culture and Leadership Style on Job Satisfaction and Organisational Commitment: A Cross-National Comparison, In: Journal of Management Development, 2004, 23, 4, 321-338

[10] Hofstede, G., Culture's Consequences: Comparing Values, Behaviors, Institutions, and Organizations across Nations, SAGE Publications Thousand Oaks, CA, 2001

[11] Hofstede, G., Hofstede, G.J., Cultures and Organizations: Software of the Mind (Rev. 2nd ed.). New York: McGrawHill, 2005

[12] Robbins, S.P., Coulter, M., Management, Data Status, Beograd, 2005

[13] Edmonds, C., Aavailable at: smartblogs.co [Accesed 20. July 2012]

[14] Carels, C., Maroun, W., Padia, N., Integrated reporting in the South African mining sector, In: Corporate Ownership and Control, 2003, 11, 1, 957-971

[15] Brennan, N., Merkl-Davies, D., Rhetoric and argument in social and environmental reporting: The dirty laundry case, In: Accounting, Auditing and Accountability Journal, 2014, 27, 4, 602-633

[16] Dube, S., Maroun, W., Corporate social responsibility reporting by South African mining companies: Evidence of legitimacy theory, In: South African Journal of Business Management, 2017, 48, 1, 23-34

[17] House, R.J., Javidan, M., Overview of GLOBE”, In: House R. J. etal. (Eds.) Culture, leadership, and organizations: the GLOBE study of 62societies. SAGE Publications, Thousand Oaks, CA, 2004

[18] Bogdanovic, D., Miletic, S., Personnel evaluation and selection by multicriteria decision making method, In: Economic Computation and Economic Cybernetics Studies and Research, 2014, 48, 3 179-196

[19] Karabašević, D., Stanujkić, D., Urošević, S., Maksimović, M., Selection of candidates in the mining industry based on the application of the SWARA and the MULTIMOORA methods, In: Acta Montanistica Slovaca, 2015, 20, 2, $116-124$

[20] Keshavarz, G.M., Zavadskas, E.K., Amiri, M., Turskis, Z., Extended EDAS Method for Fuzzy Multi-criteria Decision-making: An Application to Supplier Selection, In: International Journal of Computers, Communications \& Control, 2016, 11, 3, 358-371

[21] Kosareva, N., Zavadskas, E.K., Krylovas, A., Dadelo, S., Personnel ranking and selection problem solution by

[23] Karabašević, D., Zavadskas, E.K., Turskis, Z., Stanujkić, D., The Framework for the Selection of Personnel Based on the SWARA and ARAS Methods Under Uncertainties, In: Informatika, 2016, 27, 1, 49-65

[24] Stanujkic, D., Karabašević, D., Zavadskas, E.K., A new approach for selecting alternatives based on the adapted weighted sum and the swara methods: a case of personnel selection, In: Economic Computation and Economic Cybernetics Studies and Research, 2017, 3, 51, 39-56

[25] Hofstede, G., Culture's consequences: international differences in work-related values, SAGE Publications, Beverly Hills, CA, 1980

[26] Gupta, V., Hanges, P.J., Regional and climate clustering of societal cultures, In: R. J. House et al. (Eds.). Culture, Leadership, and Organizations: The GLOBE Study of 62 Societies, SAGE Publications, Thousand Oaks, CA, 2004

[27] Paunković, D.Z., Jovanović, R., Stojković, Z., Stojković, I., Sustainable Implementation of Information and Communication Technology in Health Care - A Case Study of Organizational and Cultural Factors, In: Sibiu Alma Mater University Journals-Series A. Economic Sciences, 2010, 3, 3, 1-6

[28] Hampden-Turner, C.M., Trompenaars, F., Buliding Cross-Cultural Competence: How To Create Wealth from Conflicting Values, New Haven: Yale University Press, 2000

[29] Schneider, S., Barsoux, J., Managing Across Cultures. Hertfordshire: Prentice Hall Europe, 1997.

[30] Schuster C., Copeland M., Cross-Cultural Communications: Issues and Implications, In: Ghauri P. \& Usunier J. (eds.) International Business Negotiations, Oxford: Pergamon Books, 1996

[31] Usunier, J., The Role of Time in International Business Negotiations, In: Ghauri P. \& Usunier J. (eds.) International Business Negotiations, Oxford: Pergamon Books,1996

[32] Schneider, S.C., National vs CorproateCulture: Implications for Human resources Management, In: V.Pucik, Tichy N\& Barnett C.(Eds.), Globalizing management, New York: John Wiley \& Sons, 1992

[33] Stephanie, D.G., Timothy, A.C., Katigbak, S.M., Reyes, J.A.S., Selfdescribed traits, values and moods associated with individualism and collectivism, In: Journal of Cross-Cultural Psychology, 1999, 30, 4, 471

[34] Romin, W.T., Lang, W.J., Smith, J.A., Self-esteem and the cultural tradeoff: evidence for the role of individualismcollectivism, In: Journal of Cross-Cultural Psychology, 1999, 30, 5, 635

[35] Snell, S.R., Hui, S.K.S., Towards the Hong Kong learning organization: an exploratory case study, In: Journal of Applied Management Studies, 2000, 9, 2, 165

[36] Ananda, M., Hurtado, P., Interpreting, categorizing and responding to theenvironment: the role of culture in strategic problem definition, In: Management Decision, 2001, 39, 110

[37] Tudor, L., Change in Textile and Clothing Industry, In: Industria Textila, 2018, 69, 1, 37-43, http://doi.org/10.35530/ IT.069.01.1449

[38] Saaty, T.L. ,The Analytic Hierarchy Process, New York, McGraw-Hill, 1980

[39] Winston, W., Albright, C., Practical management science, Revised Third Edition, London: Thomson South-Western, 2008, 484

[40] Carrillo-Hermosilla, J., Del Río, P., Könnölä, T., Diversity of eco-innovations: reflections from selected case studies, In: Journal of Cleaner Production, 2010, 18, 1073-1083 
[41] Aghion, P., Hemous, D., Veugelers, R., No Green Growth without Innovation, Bruegel, Policy Brief, November 2009

[42] European Commission, EUROPE 2020: a Strategy for Smart. Sustainable and Inclusive Growth, Brussels, 3.3.2010, Communication from the Commission, COM (2010) 2020

[43] Montalvo, C., Diaz-Lopez, F., Brandes, F., Eco-innovation Opportunities in Nine Sectors of the European Economy, European Sector Innovation Watch, European Commission, Directorate General Enterprise and Industry, Brussels, 2011

\title{
Authors:
}

SLAVICA MILETIĆ ${ }^{1}$, ŠIMŠIĆ ZDENKA STANOJEVIĆ ${ }^{1}$, IVAN JOVANOVIĆ², MILAN RADIVOJEVIĆ ${ }^{1}$, VESNA CONIĆ 1

${ }^{1}$ Mining and Metallurgy Institute Bor, Zeleni Bulevar, no. 35, 19210, Bor, Serbia e-mail: zdenkassh@irmbor.co.rs; milan.radivojevic@irmbor.co.rs; vesna.conic@irmbor.co.rs

${ }^{2}$ Technical Faculty Bor, University of Belgrade, Vojske Jugoslavije, no. 12, 19210, Bor, Serbia e-mail: ijovanovic@tfbor.bg.ac.rs

\section{Corresponding author:}

\author{
SLAVICA MILETIĆ
}

e-mail: slavica.miletic@irmbor.co.rs 


\title{
Investigations of stretch and recovery properties of knitted socks
}

\author{
DOI: 10.35530/IT.071.02.1671
}

SIKANDER ABBAS BASRA

NORINA ASFAND

ABDUL WAQAR RAJPUT

ZEESHAN AZAM

BILAL ZAHID

HAFSA JAMSHAID

\section{ABSTRACT - REZUMAT}

\section{Investigations of stretch and recovery properties of knitted socks}

Knitted fabrics are renowned for stretch properties which owe to their comfort properties such as formability, fitting to the human body and shape retention after wearing. Optimum stretch is basic requirement in knitted socks to support blood flow in legs and feet. This stretch is achieved with fabric structure type and material used in it. Different factors affect the stretch and recovery of sock, but most contributing factors are elastane percentage, main yarn material and finishing process type. Four different percentages of elastane in plaiting (4\%, 6\%, 8\% and 10\%), two main yarns materials (Cotton and Polyester/Cotton PC), and two finishing process types(Wash and bleach) were taken as level of input variables to study their effect on stretch and recovery. Stretch and recovery tests were performed on knitted sock tube. After testing, Minitab software was used for analysis of variance of obtained results using full factorial design. Significance of all factors and levels was analyzed. It was found that with the increase in elastane percentage stretch was decreased and recovery was increased. Cotton was found to have less stretch and more recovery percentage as compared to PC. Additionally it was observed that washing treatment produced significantly higher stretch and lesser recovery than bleaching. Similar trend was also observed in interaction plot indicating that all variables were dependent on each other.

Keywords: socks, elastane percentage, cotton, polyester/cotton PC, stretch, recovery, full factorial design

Analiza proprietăților de întindere și revenire din întindere ale șosetelor tricotate

Materialele textile tricotate sunt renumite pentru proprietățile de întindere, care conferă și proprietăți de confort, cum ar fi formabilitatea, potrivirea pe corpul uman și păstrarea formei după purtare. Întinderea optimă este o cerință de bază la șosetele tricotate pentru a susține fluxul de sânge în membrele inferioare. Această întindere se obține prin structura tricotului și materia primă utilizată. Diferiți factori influențează întinderea și revenirea din întindere a șosetei, dar cei mai importanți sunt procentul de elastan, materia primă principală a firului și tipul procesului de finisare. Patru procente diferite de elastan (4\%,6\%, 8\% și 10\%), două materii prime principale ale firului (bumbac și poliester/bumbac PC) și două tipuri de procedee de finisare (spălare și albire) au reprezentat variabilele de intrare pentru a studia influența lor asupra întinderii și revenirii din întindere. Au fost efectuate teste de întindere și revenire din întindere pentru şosetele tricotate tubular. După testare, software-ul Minitab a fost utilizat pentru analiza variației rezultatelor obținute aplicând modelul factorial complet. Astfel, a fost analizată semnificația tuturor factorilor și nivelurilor. S-a constatat că odată cu creșterea procentului de elastan a scăzut nivelul de întindere, iar revenirea din întindere a crescut. S-a constatat că bumbacul prezintă un nivel mai redus de întindere și o revenire mai mare din întindere în comparație cu PC. În plus, s-a observat că tratamentul de spălare a produs o întindere semnificativ mai mare și o revenire din întindere mai mică decât albirea. O tendință similară a fost observată și în graficul de interacțiune care indică faptul că toate variabilele erau dependente unele față de altele.

Cuvinte-cheie: șosete, procent de elastan, bumbac, poliester/bumbac PC, întindere, revenire din întindere, model factorial complet

\section{INTRODUCTION}

Knitted fabrics provide excellent comfort properties. These fabrics are preferred in many kinds of clothing due to their superior properties. Knitted fabrics are produced on different machines with combinations of different type of stitches and color combinations to create different patterns and fabric types [1]. Knitted socks are designed to provide comfort, absorb and evaporate sweat, protect foot, warm/cool the foot or as a fashion. Parts of socks may be welt, leg, ankle, high heel, heel, foot, arch support, and toe. Types of yarns being used in sock are main yarn, plaiting yarn, elastic yarn/gripping yarn, motif yarn/pattern yarn, splicing yarn and technical yarn [2]. In elastic contents of yarn, a soft and flexible segment (polyester/ polyether/polyols) is bonded with rigid and hard segments (urethane) and technically termed as segmented polyurethane. This composition provides the lasting and built in stretch to the fiber [3-4]. The stretch of a fabric can be defined as "the strain produced in a specimen of fabric on application of stress under specific conditions" (equation 1).

Fabric stretch \% =

$=$ Increase in length of a specimen on tension Original length prior to tension force 
The work recovery of the fabric can be defined as "ratio of the recovered elastic energy and the total tensile energy applied for the specific strain" (equation 2).

$$
\begin{gathered}
\text { Fabric recovery } \%= \\
=\frac{\text { Tensile energy (unloading) }}{\text { Tensile energy loading }} \times 100
\end{gathered}
$$

Senthilkumar M. and Anbumani N. studied the effect of different extension levels on stretch and recovery properties of garment during body movements. They concluded that the spandex plaited cotton fabric showed higher elastic recovery as compared to core spun spandex with cotton fabrics [5]. Serkan Tezel et al. investigated the effect of elastane on properties of single jersey fabric developed with cotton and spandex. It was concluded that elastane significantly influenced the properties of fabric since spandex brands with higher tension give highest weight, high thickness and stitch density. The presence of spandex, however reduced the air permeability of the fabric as compared to $100 \%$ cotton fabric [6]. Burji M. et al. investigated that spandex back plaiting increases stretchability and elastic recovery of the fabric more than core cotton spun fabric and hence are more suitable for sportswear. It also exerts more pressure on body than core spun with yarn [7]. Bilal Qadir et al. concluded that the fabric stretchability and recovery after stretch increases with higher denier elastane in core-spun cotton yarn. They also concluded that increase in elastane draft ratio enhanced the stretch-ability and reduced the recovery after stretch [8]. Lukkassen D. et al. investigated the effect of polyester and nylon on properties of sportswear fabrics. They concluded that polyester and nylon showed exceptional, dimensional stability, optimum strength, high stretch and recovery properties. It was also found that these yarns had excellent abrasion resistance and resistance to dirt, decay and mould in sportswear [9]. Senthilkumar, and N. Anbumani, investigated stretch and recovery properties of the cotton/spandex knitted fabric. They found that with the increase of spandex linear density, stretch and recovery of the fabric increases. It was also studied that dynamic work recovery of the fabric at greige stage is higher which decreased after heat setting and bleaching but after compaction dynamic work recovery of the fabric was slightly increased [10]. Saber Ben Abdessalem et al. studied the relation between Lycra ${ }^{\circledR}$ consumption and fabric dimensional and elastic behaviour. In cotton Lycra ${ }^{\circledR}$ blend with increased tension on Lycra ${ }^{\circledR}$ yarn decreased the consumption of Lycra ${ }^{\circledR}$ and hence decreased the width of the fabric. Furthermore, the fabric recovery also decreased with the decrease in Lycra ${ }^{\circledR}$ consumption [11].

As per knowledge of this author, stretch and recovery behaviour of different knitted fabrics i.e. single jersey, rib, interlock, fleece had been studied earlier but no significant research has been carried out on socks to sort out the problem of uneven stretch and recovery keeping in view the elastane percentage and finishing process applications. Hence, this study provides better understanding of the effect of different variables on stretch and recovery properties of socks. In this research, different percentages of elastane and different finishing processes were applied on plain plaiting knitted socks on a same gauge and their stretch and recovery properties have been studied. Objectives of this research are to investigate the effect of elastane percentage, main yarn type and finishing process type on stretch and recovery percentage in length and width of welt and foot by using Full Factorial Design method and analysis of variance (ANOVA) statistical approaches.

\section{MATERIAL AND METHODS}

This study was focused to investigate the stretch and recovery properties of plaited knitted socks on the basis of the $70 \mathrm{D} 24$ filaments nylon covered elastane percentage $(4 \%, 6 \%, 8 \%$, and $10 \%)$ in core and the type of main yarns used were $20 \mathrm{Ne}$ Cotton and 20 Ne Polyester/Cotton. Total sixteen samples were developed with combination of these yarns with washing and bleaching. Design of experiment is given in table 1. Full factorial experiments are the ones where investigation of the impact of greater than one factors over response is carried out. Also, the number of experiments geometrically increases with the increasing number of factors and levels [12-13].

Samples were developed on 14E knitting machine. In welt and foot elastic inlaid plaited and plain plaited fabric structures were developed respectively. Samples relaxed in the standard atmosphere of $20 \pm 2^{\circ} \mathrm{C}$ and $65 \pm 4 \%$ relative humidity for 24 hours

Table 1

\begin{tabular}{|c|c|c|c|}
\hline \multicolumn{4}{|c|}{ DESIGN OF EXPERIMENT } \\
\hline \multirow{2}{*}{ Run } & \multicolumn{3}{|c|}{ Factors } \\
\cline { 2 - 4 } & Plaiting yarn & Main yarn & $\begin{array}{c}\text { Finishing } \\
\text { process }\end{array}$ \\
\hline 1 & Nylon with Elastane 4\% & Cotton 100\% & Wash \\
\hline 2 & Nylon with Elastane 6\% & Cotton 100\% & Wash \\
\hline 3 & Nylon with Elastane 8\% & Cotton 100\% & Wash \\
\hline 4 & Nylon with Elastane 10\% & Cotton 100\% & Wash \\
\hline 5 & Nylon with Elastane 4\% & PC 52:48 & Wash \\
\hline 6 & Nylon with Elastane 6\% & PC 52:48 & Wash \\
\hline 7 & Nylon with Elastane 8\% & PC 52:48 & Wash \\
\hline 8 & Nylon with Elastane 10\% & PC 52:48 & Wash \\
\hline 9 & Nylon with Elastane 4\% & Cotton 100\% & Bleach \\
\hline 10 & Nylon with Elastane 6\% & Cotton 100\% & Bleach \\
\hline 11 & Nylon with Elastane 8\% & Cotton 100\% & Bleach \\
\hline 12 & Nylon with Elastane 10\% & Cotton 100\% & Bleach \\
\hline 13 & Nylon with Elastane 4\% & PC 52:48 & Bleach \\
\hline 14 & Nylon with Elastane 6\% & PC 52:48 & Bleach \\
\hline 15 & Nylon with Elastane 8\% & PC 52:48 & Bleach \\
\hline 16 & Nylon with Elastane 10\% & PC 52:48 & Bleach \\
\hline
\end{tabular}




\begin{tabular}{|c|c|c|c|c|c|}
\hline \multicolumn{7}{|c|}{ KNITTING PARAMETERS OF PLAIN PLATED FABRIC } \\
\hline $\begin{array}{c}\text { Course per unit } \\
\text { area }\left(\mathbf{c m}^{-1}\right)\end{array}$ & $\begin{array}{c}\text { Wales per unit } \\
\text { area }\left(\mathbf{c m}^{-1}\right)\end{array}$ & $\begin{array}{c}\text { Stitch density } \mathbf{~ p e r} \\
\text { unit area }\left(\mathbf{c m}^{-2}\right)\end{array}$ & $\begin{array}{c}\text { Stitch length } \\
(\mathbf{m m})\end{array}$ & $\begin{array}{c}\mathbf{R} \\
\left(\mathbf{K}_{\mathbf{c}} / \mathbf{K}_{\mathbf{w}}\right)\end{array}$ & $\begin{array}{c}\text { Tightness factor } \\
(\sqrt{\text { Tex}} / \mathbf{S L})\end{array}$ \\
\hline 12.6 & 9.06 & 114.08 & 5.3 & 1.39 & 10.25 \\
\hline
\end{tabular}

for dry relaxation. Knitted fabric parameters were determined according to standard test methods. Welt length was adjusted at $3 \mathrm{~cm}$ and welt width was adjusted at $8 \mathrm{~cm}$ on knitting machine for all samples. Foot length and width was also adjusted on knitting machine for all samples at 17 and $10 \mathrm{~cm}$ respectively. All the knitting parameters were verified according to standard tests method ASTM D3887. Parameters of plain plated knitted fabric are given in table 2 .

Wash and bleach finishing processes were applied on these samples after conditioning and evaluation of parameters. After washing and bleaching, steam was applied for 20 minutes for tumble drying and re-conditioning was done at standard atmosphere of $20 \pm 2^{\circ} \mathrm{C}$ and $65 \pm 4 \%$ relative humidity for 24 hours for dry relaxation. Stretch and recovery percentage was measured according to ASTM D2594-99a standard test method. Percentage Stretch of welt and foot was calculated on stretch equipment (CETME specifically used for sock). CETME tester was used to determine dimensional changes. Specimens were fixed between two jaws in width direction and lever holding these jaws were dropped down manually at standard carriage weight of $4.65 \mathrm{Kgs}$.

The results were analyzed by ANOVA with the help of Minitab software. Full factorial design was selected for data analysis. ANOVA was performed in order to determine the statistical significance of experimental factors i.e. effect of elastane percentage in plaiting yarn, fiber type in main yarn, type of finishing process against their response variables i.e stretch and recovery of socks parts, at 95\% confidence level. Due to the $95 \%$ confidence interval, the parameters with $\mathrm{P}<0.05$ values indicate that the effect of that parameter on the given experimental layout is statistically significant. Interaction plot also studied to find out dependency level of input variables.

\section{RESULTS AND DISCUSSIONS}

Effect of input variables were studied on stretch and recovery properties of socks. After washing and bleaching, stretch and recovery percentage in welt width and foot width was calculated. Five specimens of each sample were taken for each measurement. Standard deviation and mean values of measurements were calculated. Effect of experimental variables on stretch and recovery is given in table 3 .

\section{Impact on stretch percentage of welt width}

Effect of elastane in plaiting yarn was found with significant effect $(p$-value $=0.005$ ) on stretch percentage of welt width. Main yarn type has a statistically significant ( $p$-value $=0.022$ ) effect with $95 \%$ confidence. Finishing process type i.e bleaching and

Table 3

\begin{tabular}{|c|c|c|c|c|c|c|c|c|}
\hline \multicolumn{9}{|c|}{ EFFECT OF EXPERIMENTAL VARIABLES ON STRETCH AND RECOVERY PROPERTIES } \\
\hline \multirow{2}{*}{$\begin{array}{c}\text { Sample } \\
\text { no. }\end{array}$} & \multicolumn{2}{|c|}{ Welt Stretch (\%) } & \multicolumn{2}{|c|}{ Foot Stretch (\%) } & \multicolumn{2}{|c|}{ Welt Recovery (\%) } & \multicolumn{2}{|c|}{ Foot Recovery (\%) } \\
\hline & Mean & S.D & Mean & S.D & Mean & S.D & Mean & S.D \\
\hline 1 & 209.38 & 0.44 & 142.50 & 0.00 & 86.75 & 0.20 & 85.14 & 0.10 \\
\hline 2 & 206.25 & 2.21 & 140.20 & 0.45 & 89.15 & 0.16 & 91.03 & 0.13 \\
\hline 3 & 202.75 & 2.85 & 135.90 & 1.24 & 92.65 & 0.12 & 91.86 & 0.12 \\
\hline 4 & 200.63 & 2.25 & 138.00 & 1.17 & 94.53 & 0.16 & 92.74 & 0.12 \\
\hline 5 & 212.50 & 0.88 & 150.40 & 0.55 & 82.00 & 0.25 & 80.09 & 0.15 \\
\hline 6 & 208.88 & 2.52 & 147.50 & 0.35 & 83.39 & 0.17 & 81.19 & 0.09 \\
\hline 7 & 208.00 & 1.90 & 145.00 & 0.00 & 86.31 & 0.19 & 84.68 & 0.06 \\
\hline 8 & 206.13 & 1.79 & 140.20 & 0.45 & 87.76 & 0.19 & 86.05 & 0.12 \\
\hline 9 & 192.75 & 1.37 & 110.00 & 0.71 & 85.24 & 0.15 & 84.50 & 1.37 \\
\hline 10 & 190.63 & 0.44 & 115.00 & 0.71 & 89.09 & 0.18 & 87.25 & 2.93 \\
\hline 11 & 189.00 & 2.01 & 110.00 & 0.71 & 93.16 & 0.17 & 89.75 & 0.44 \\
\hline 12 & 188.25 & 3.57 & 100.20 & 0.84 & 95.91 & 0.19 & 92.15 & 1.79 \\
\hline 13 & 193.25 & 0.68 & 117.60 & 0.22 & 83.60 & 0.18 & 85.25 & 0.56 \\
\hline 14 & 190.00 & 2.93 & 112.50 & 0.35 & 87.08 & 0.23 & 88.23 & 1.90 \\
\hline 15 & 187.88 & 3.41 & 110.40 & 0.55 & 89.79 & 0.12 & 90.20 & 0.68 \\
\hline 16 & 187.75 & 0.56 & 102.50 & 0.35 & 93.22 & 0.12 & 94.20 & 0.44 \\
\hline
\end{tabular}


washing has significant impact on stretch percentage of welt width of sock ( $p$-value $=0.00)$. The degree of stretch depends on the amount and type of elastane incorporated for construction of the fabric [6]. In weft knitted structures, interlocking of loops can be pulled and stretched in different directions giving the knitted fabrics a higher degree of stretch. Low percentage of elastane contained more crimp per unit area as compared to higher percentage of elastane in covered yarn. High crimps in nylon yarn due to drafted elastane produced higher stretch in welt width. With application of load, high crimp yarn causes more increase in yarn length as compare to low crimp covered yarn. In nylon, where less elastane $\%$ is used as sheath leads to increase in tension of yarn, decreases the consumption of elastane. Due to this, width of the fabric decreases and stretch \% increases [8]. That's why stretch of $4 \%$ elastane covered nylon socks is higher as compared to $6 \%, 8 \%$ and $10 \%$. Slacker fabrics have higher stretch as compared to denser fabric. A Mukhopadhyay et.al.in their research concluded that, fabric made with elastane covered yarn, the immediate recovery, extension and resiliency are higher but delayed recovery and permanent set are lower than those of $100 \%$ spun or filament yarn fabrics [15]. In bleaching the stretch of fabric was reduced due to increase in stitch density as shown in figure 1. Cotton leads high shrinkage as compare to polyester/cotton yarn. The stretch percentage was decreased due to compactness of cotton main yarn as compared to polyester/cotton yarn. In $100 \%$ of cotton yarns, fiber-to-fiber frictions are superior to fiber-to-fiber friction in cotton and polyester in PCs that reduce stretching.

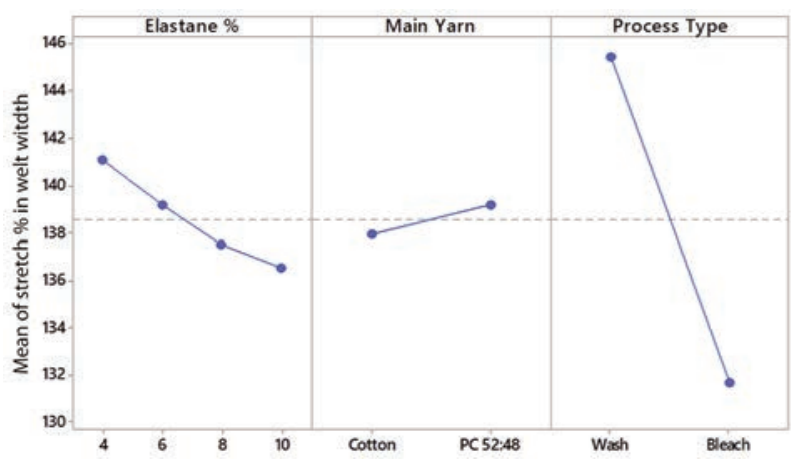

Fig. 1. Main effect plot for stretch in welt width

\section{Impact on stretch percentage of foot width}

Effect of elastane in plaiting yarn was found having significant effect $(p$-value $=0.039)$ on stretch percentage of foot width. Main yarn type has a statistically significant $(p$-value $=0.048$ ) effect with 95\% confidence. Finishing processing type, bleaching and washing has significant impact on stretch percentage of foot width of sock ( $p$-value $=0.00)$. Elastane fibers consist of soft (flexible) segments bonded together with hard segments giving the fiber a built-in stretch. In weft knitted structures, the yarns follow a meandering path forming systematic loops above and below the mean path of the yarn systematically. These interlocking of loops can be pulled and stretched in different directions giving the knitted fabrics a higher degree of stretch. Nylon covering with low percentage of elastane contained high crimp; these crimps increased the stretch percentage of foot width. In the nylon elastane, the increased tension in the elastane yarn decreases the elastane consumption and, therefore, decreases the width of the fabric and increases the stretch [8]. That is why the stretch of $4 \%$ elastane covered knitted nylon socks is higher compared to $6 \%, 8 \%$ and $10 \%$. Higher percentage carry small crimps on nylon that's why higher percentages of elastane in covered yarn has less stretch percentage as shown in figure 2. Washed sample showed higher stretch percentage due to less shrinkage percentage as compared to bleached samples. Shrinkage percentage in cotton samples was higher as compare to PC. PC socks also carried higher stretch as compared $100 \%$ cotton respectively due to slacker knitted fabrics less compactness. In $100 \%$ cotton yarn fibre to fibre frictions are higher as compare to fibre to fibre friction of cotton and polyester in $\mathrm{PC}$ which reduces stretch.

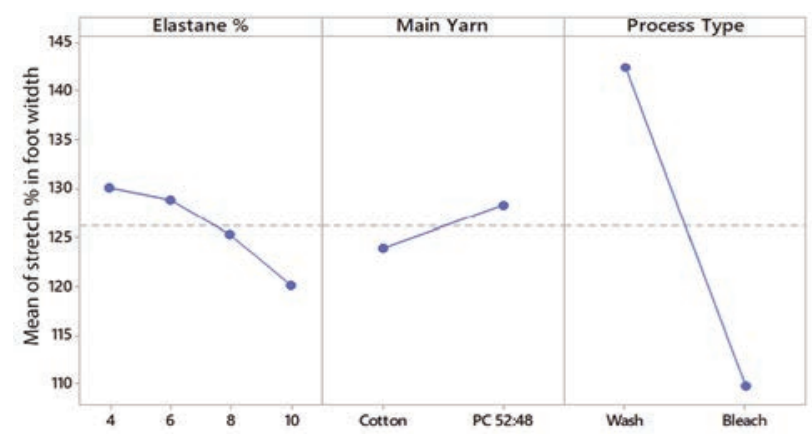

Fig. 2. Main effect plot for foot width

\section{Impact on recovery percentage of welt width}

Effect of elastane in plaiting yarn was found with significant effect of $(p$-value $=0.00)$ on recovery percentage of welt width. Main yarn type has a statistically significant ( $p$-value $=0.00$ ) effect with 95\% confidence. Finishing processing type, bleaching and washing has significant impact on recovery percentage of welt width of sock ( $p$-value $=0.00)$. The recovery percentage increased with increase in elastane percentage as shown in figure 3 . This is due to presence of highly elastic yarn offering less frictional contact between interlocking points of loops. Higher the compactness of fabric more will be its ability to generate and maintain pressure. Loops will tend to revert to its original shape and position as soon as the mechanical stresses were removed from fabric. This may be due to decrease in tenacity of elastane. In elastane covered with nylon, the increased tension in the elastane thread reduces the consumption of elastane and, therefore, the width of the fabric reduces and the recovery of the fabric also decreases with the decrease in elastane consumption. When the extension ratio increases, the plastic extension increases 
and elasticity decreases and, as a result, elastic recovery decreases [14]. Cotton shows higher recovery percentage as compared to polyester/cotton due to jamming of loops. Higher shrinkage reduces area of fabric which recovered easily as compare to slacker fabrics. That's why recovery of cotton and bleached fabrics were higher as compare to PC and washed samples respectively. Dynamic work recovery of the fabric at grey stage is higher which decreased after heat setting and bleaching but after compaction dynamic work recovery of the fabric found to be increased somewhat [16]. Bleaching showed higher recovery percentage as compared to washing due to interlocking of loops during bleaching process as shown in figure 3.

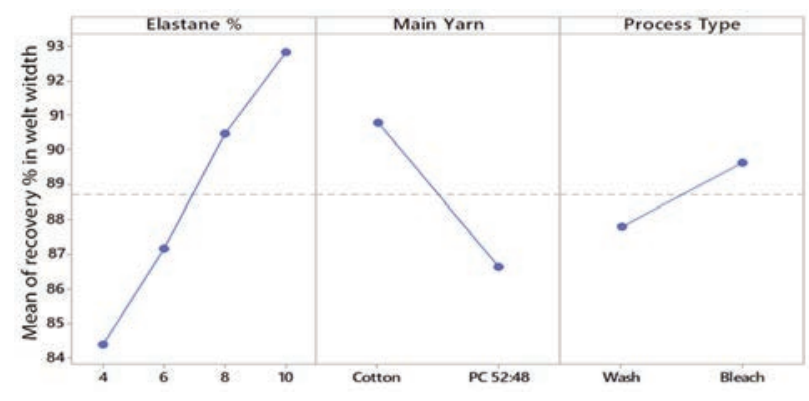

Fig. 3. Main effect plot for welt width

\section{Impact on recovery percentage of foot width}

Effect of elastane in plaiting yarn on recovery percentage of foot width was found significant ( $p$-value = 0.007 ). Main yarn type has a statistically significant ( $p$-value $=0.010)$ effect with 95\% confidence. Finishing processing type, bleaching and washing has significant impact on recovery percentage of foot width of sock $(p-v a l u e=0.021)$. In nylon covered elastane with increased tension on elastane yarn decreases the consumption of elastane and hence decreases the width of the fabric and fabric recovery also decreases with decrease in elastane consumption. When the extension ratio increases the plastic extension increases and the elastic one decreases and consequently the elastic recovery decreases
[14]. Fabric compactness increased with increase in stitch density of fabric. Higher the compactness of fabric more will be its ability to generate and maintain pressure. Greater shrinkage reduces the area of easily recoverable as compared to slacker fabrics. Therefore recovery of cotton and bleached fabrics was higher than that of PC and washed samples. The dynamic recovery of the work of the fabric in the gray stage is greater, which decreased after the thermal setting and the discoloration, but after the compaction, the dynamic recovery of the work of the fabric increased a bit [16]. Recovery percentage of foot width was increased in bleached due to higher retracting force of fabric loops towards recovery due to higher stitch density as shown in figure 4.

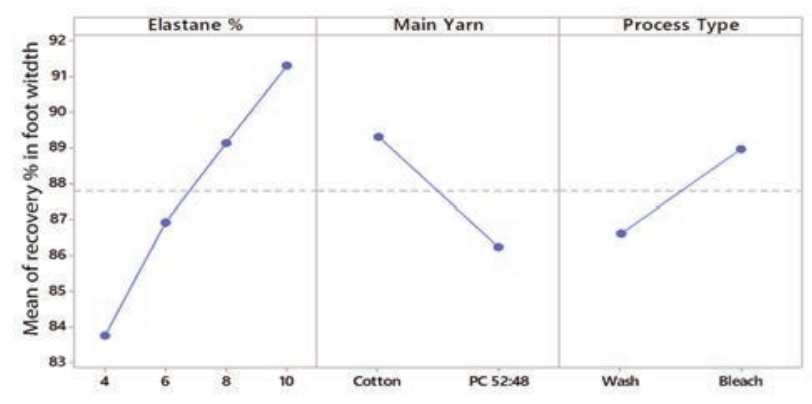

Fig. 4. Main effect plot for foot width

\section{CONCLUSION}

It was found that with the increase in elastane percentage, stretch was decreased in welt and foot. Cotton was found to have less stretch as compared to PC. Additionally it was observed that washing treatment produced significantly higher stretch than bleaching. In stretch percentage all variables are dependent on each other.

The recovery percentage increased with increase in elastane percentage in both welt and foot. Cotton has higher recovery percentage as compared to $\mathrm{PC}$ and bleaching process showed higher recovery percentage as compared to washing. It was also observed in interaction plot that all variables are dependent on each other.

\section{REFERENCES}

[1] Sadhan Chandra, R., Fundamentals and advances in knitting technology, WPI Publishing, 2012

[2] Anastsopoulos, M., Totham, D., Van Veen, A., Jones, J., US 2009/0044313 A1 United States of America, 2009

[3] Fiori, S., Mariani, A., Ricco, L., Russo, S., First synthesis of a polyurethane by frontal polymerization, In: Macromolecules, 2003, 2674-2679

[4] Krol, P., Synthesis methods, chemical structures and phase structures of linear polyurethanes. Properties and applications of linear polyurethanes in polyurethane elastomers, copolymers and ionomers, In: Progress in materials science, 2007, 915-1015

[5] Senthilkumar, M., Anbumani, N., Dynamics of Elastic Knitted Fabrics for Sports Wear, In: Textile Research Journal, 2011, 13-25

[6] Tezel, S., Kavuşturan, Y., Experimental Investigation of Effects of Spandex Brand and Tightness Factor on Dimensional and Physical Properties of Cotton/Spandex Single Jersey Fabrics, In: Textile Research Journal, 2008, 966-976

[7] Burji, M., Kadole, P.V., Lokesh, K.V., Effect of twist levels in polyester yarn on elastic behavior of polyester/spandex air covered yarn, Melliand International, 2015

[8] Qadir, B., Hussain, T., Malik, M., Effect of Elastane Denier and Draft Ratio of Core-Spun Cotton Weft Yarns on the Mechanical Properties of Woven Fabrics, In: Journal of Engineered Fabrics and Fibers, 2014 
[9] Lukkassen, D., Meidell, A., Advanced materials and structures and their fabrication processes, Narrik University College, 2003

[10] Senthilkumar, S.S.M., Anbumani, N., Effect of Spandex Input Tension, Spandex Linear Density and Cotton Yarn Loop Length on Dynamic Elastic Behavior of Cotton/Spandex Knitted Fabrics, In: Journel Text. Apparel, Technol. Manag, 2012

[11] Ben Abdelkader, Y., Mokhtar, S., Elmarzougui, S., Influence of Elastane Consumption on Plated Plain Knitted Fabric Characteristics, Saber Ben Abdessalem, 2010

[12] Kavak, D.N., Boron removal from aqueous solutions by adsorption on waste sepiolite and activated waste sepiolite using full factorial design, In: Adsorption, 2004, 245-257

[13] Hande Sezgin, S.K., Thermal analysis of e-textile structures using full-factorial experimental design method, In: Journal of Industrial Textiles, 2014, 752-764

[14] Helali, H., Babay Dhouib, A., Msahli, S., Cheikhrouhou, M., Influence of Dorlastan® draft and yarn count on the elastic recovery of the Dorlastan $\AA$ core spun yarns following cyclic test, In: The Journal of the Textile Institute, 2012, 378-384

[15] Mukhopadhyay, A., Sharma, I.C., Mohanty, A., Impact of lycra filament on extension and recovery characteristics of cotton knitted fabrics, In: Indian Journal of Fibre and Textile Research, 2003, 423-430

[16] Pérez-Soriano, P., García-Roig, Á., Sanchis-Sanchis, R., Influence of compression sportswear on recovery and performance: A systematic review, In: Journal of Industrial Textiles, 2018, 1505-1524

Authors:

SIKANDER ABBAS BASRA ${ }^{1}$, ABDUL WAQAR RAJPUT², BILAL ZAHID ${ }^{3}$, NORINA ASFAND ${ }^{1}$, ZEESHAN AZAM ${ }^{1}$, HAFSA JAMSHAID ${ }^{1}$

${ }^{1}$ Protective Textile Research Group, Faculty of Engineering \& Technology, National Textile University, Pakistan e-mail: basra.ntu@gmail.com, norina892@gmail.com, zeeshanazam250@gmail.com

${ }^{2}$ Technical Textile Research Group, BZU College of Textile Engineering, Multan, Pakistan e-mail: waqar.rajput@bzu.edu.pk

${ }^{3}$ Textile Engineering Department, NED University of Engineering and Technology, Karachi - 75270, Sindh, Pakistan

e-mail: drbilalzahid@neduet.edu.pk

Corresponding author:

HAFSA JAMSHAID

email: hafsa@ntu.edu.pk 


\title{
Textile packaging - the connection between science and health
}

\author{
DOI: $10.35530 / I T .071 .02 .1636$
}

\section{ABSTRACT - REZUMAT}

\section{Textile packaging - the connection between science and health}

According to the Report presented in the ONU Program for Development there are eight dimensions of international security (collective security) and national security: economic-social security, food security, environmental security, community security, personal security, political security and individual security, to which demographic security and military security could be added. Although there have been concerns about the nutrition status of the population since ancient times, it was only in the middle of the last century that the scientific and institutional bases of contemporary food and nutrition policies were laid.

Food and nutrition policies are represented by a series of objectives, priorities, norms and decisions adopted by the invested factors and institutions with the competences necessary to ensure to the entire population the economic and social conditions for a good state of individual and public health.

Packaging has become one of the most important functions of a product, of a commodity on the market. The packaging is part of the Food Contact Materials (FCMs) group, which should not affect the health of consumers or alter the quality of the products.

The breadth and complexity of the socio-economic context in the food contact sector requires finding additional ways to adapt.

In this context, the textile sector, respectively the field of technical textiles, through the potential of functionalities, can make a special contribution to achieving a level of coherence between the field of functionalized materials intended for food packaging - environment - consumer health - free movement of products - efficient functioning of the internal market.

Keywords: textile packaging, legislation, functions, requirements, principles

\section{Ambalaje textile - legatura dintre ştiinţă şi sănătate}

În conformitate cu Raportul prezentat în cadrul Programului ONU pentru Dezvoltare există 8 dimensiuni ale securităţii internaţionale (securităţii colective) şi securităţii naţionale: securitatea economico-socială, securitatea alimentară, securitatea mediului, securitatea comunităţii, securitatea personală, securitatea politică şi securitatea individuală, la care s-ar mai putea adăuga securitatea demografică şi securitatea militară. Cu toate că au existat preocupări pentru starea de nutriţie a populaţiei încă din cele mai vechi timpuri, abia spre mijlocul secolului trecut s-au pus bazele ştiinţifice şi instituţionale ale politicilor alimentare şi nutriţionale contemporane.

Politicile alimentare şi nutriţionale sunt reprezentate de o serie de obiective, priorităţi, norme şi decizii adoptate de factorii şi instituţiile învestite cu competenţele necesare pentru a asigura întregii populaţii condiţiile economico-sociale pentru o stare bună a sănătăţii individuale şi publice.

Ambalarea a devenit una dintre cele mai importante funcţii ale unui produs, a mărfurilor pe piaţă. Ambalajele fac parte din grupa Food Contact Materials (FCMs), care trebuie să nu afecteze sănătatea consumatorilor sau să modifice calitatea produselor.

Amploarea şi complexitatea contextului socio-economic din sectorul materialelor destinate contactului cu alimentele impune găsirea unor modalităţi suplimentare pentru a se adapta.

În acest context sectorul textil, respectiv domeniul textilelor tehnice, prin potenţialul funcţionalităţilor, poate avea o contribuţie deosebită la atingerea unui nivel de coerență între domeniul materialelor funcționalizate destinate ambalării alimentelor - mediu - sănătatea consumatorilor - libera circulaţie a produselor - eficientă funcţionare a pieţei interne.

Cuvinte cheie: ambalaje textile, legislație, funcţii, cerinţe, principil

\section{INTRODUCTION}

Food and drink are some of the greatest traditions and pleasures of our society. Today we have access to an impressive variety and quality of food and drinks. The food sector is an indelible part of the social, economic and cultural edifice of Europe. But, like most progresses, this comes with challenges. The European food and drink industry want to play its role as an active partner in addressing these challenges to ensure that Europe continues to have the highest quality and safest food in the world, taking care of the environment [1].

Food quality and safety have become consumers rights, with direct effects on quality of life, and issues focused on product quality and safety are the focus of the bodies set up to protect consumers interests. 
At the European level:

- Food is a fresh or processed product, with nutritional value, used as nutrition.

- Food security aims to ensure the self-sufficiency, respectively the sufficiency of food products for some target entities (areas, countries, groups of countries), with the help of food aid tools, donations, projects, programs etc.

Food security has different meanings in the literature [2]:

- Aims to ensure access for everyone to a healthy food.

- Aims to ensure food availability.

- Ensures and respects the right of every person to feed and the desire to have a healthy diet.

- It is a basic component of the social, economic stability and, explicitly, of the national security of a state (either with or without agricultural potential).

Food safety refers in particular to the safety of foodstuffs, with an emphasis on reducing, eliminating and avoiding the risks that food could pose to human and animal health.

Food safety - a component of food security - is a parameter that concerns the consumer and in its assurance all the component parts involved in the production, processing, transport and distribution of food are involved.

According to Codex Alimentarius,

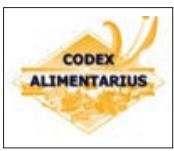

(Food

Book - a collection of internationally recognized standards, codes of good practice, food guides and recommendations, food production and food safety) food safety is "the guarantee that food will not harm consumers when they are prepared and/or consumed in accordance with the specifications regarding the use method" (table 1) [3].

For a food product - unprocessed, partially processed, totally processed or newly created - to be safe, it must meet three conditions, namely [4-6] (table 2).

\begin{tabular}{l}
$\qquad$ COMMISSION OF CODEX ALIMENTARIUS - PURPOSE \\
\hline Consumer health protection, ensuring honest practices in food trade \\
Promote the coordination of works, ensuring honest practices regarding food trade \\
Determining priorities and initiating guides for the preparation of draft standards through, and with the help of appro- \\
priate organizations \\
Finalizing the elaborated standards and publishing them in Codex Alimentarius, improving the standards after the \\
appropriate review in the light of progress.
\end{tabular}

\begin{tabular}{|c|c|}
\hline \multicolumn{2}{|r|}{ CONDITIONS THAT ENSURES FOOD SAFETY } \\
\hline Conditions & Requirements \\
\hline $\begin{array}{l}\text { Hygienic quality } \\
\text { (sanitation, safety) }\end{array}$ & $\begin{array}{l}\text { Food safety is determined by: } \\
\text { - quality of raw materials and auxiliaries; } \\
\text { - modes of transport and storage of raw materials; } \\
\text { - the hygienic-sanitary conditions and the technological processes for their processing, of } \\
\text { the storage conditions of the finished products; } \\
\text { - hygienic-sanitary conditions for transport and marketing of food products. } \\
\text { Safety/hygiene quality is an integral part of global quality and is influenced by: } \\
\text { - toxic substances that are naturally found in raw materials or finished products (alkaloids, } \\
\text { biogenic amines etc.); } \\
\text { - antinutrient substances from agri-food raw materials: hemagglutinins or lectins, trypsin } \\
\text { inhibitors, antivitamins, antimineralizers, blockers of various enzymes etc.; } \\
\text { - additives - those additives that are used in food production without compliance with the } \\
\text { legislation in effect with reference to the destination, doses etc.; } \\
\text { - chemical contaminants such as heavy metals, pesticides, mycotoxins. }\end{array}$ \\
\hline $\begin{array}{c}\text { To have nutritional and } \\
\text { energetic value }\end{array}$ & $\begin{array}{l}\text { - The intrinsic nutritional value is expressed by the quality and quantity of the main nutri- } \\
\text { ents: proteins, lipids and carbohydrates that are energy providers. Contents of minerals, } \\
\text { vitamins and other biologically active substances are also important. } \\
\text { Nutrients in food are those exogenous compounds (which come from outside the body), } \\
\text { which, after prior digestion and absorption, participate in metabolism, a process indispens- } \\
\text { able to life, while also ensuring cellular nutrition. }\end{array}$ \\
\hline $\begin{array}{l}\text { Food nutrients must be } \\
\text { available to the body }\end{array}$ & $\begin{array}{l}\text { - High bioavailable nutritional value. Food bioavailability refers to the extent to which nutri- } \\
\text { ents, biominerals, vitamins and biologically active substances are used by the human body. } \\
\text { Bioavailability is influenced by a number of factors, respectively: the physiological state of } \\
\text { the organism, the nature of the product, the presence of antinutritional substances, the way } \\
\text { of processing the raw material, the synergistic, antagonistic or associative interactions } \\
\text { between nutrients and biominerals or nutrients and vitamins. }\end{array}$ \\
\hline
\end{tabular}




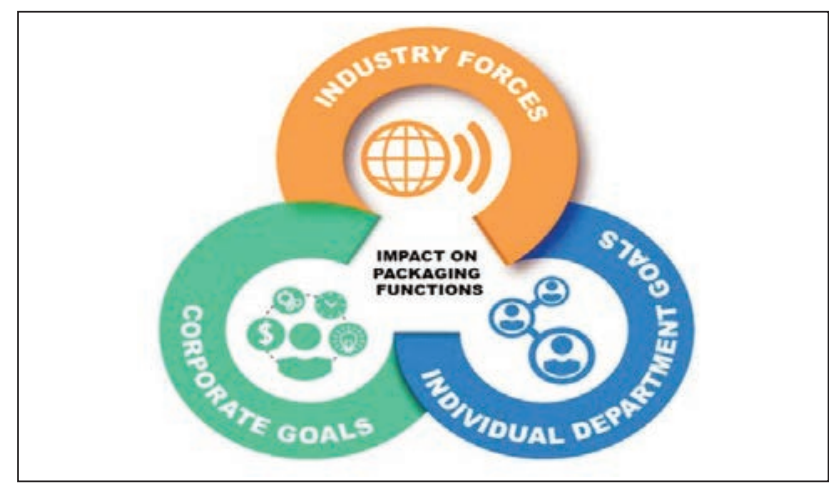

Fig. 1. The strategy of packaging [7]

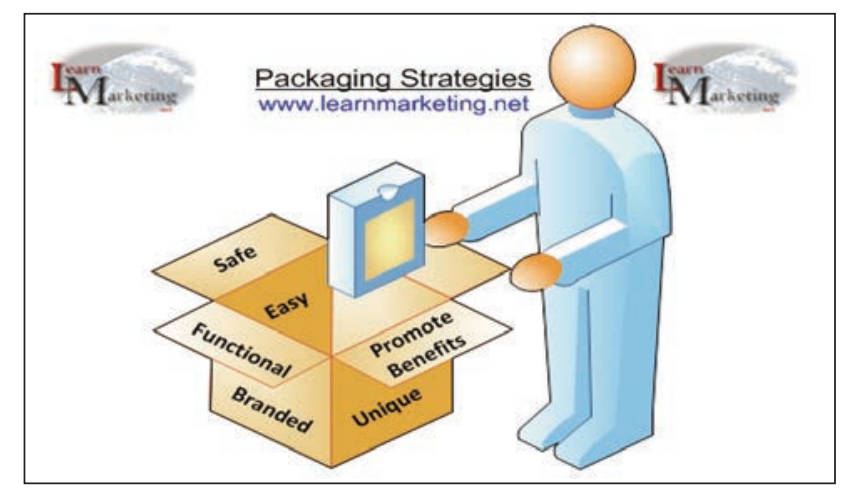

Fig. 2. The six functions of the packaging process [8]

The "packaging" strategy in the field is an important side for the sustainability of the producers and influences both the corporate objectives, the individual objectives of the departments, as well as the general objectives of the industry to which the respective producer belongs (figure 1).

The packaging offers a lot of information about the product itself from the technical point of view, of the image, but also about the content of the product. The packaging must fulfil six functions, namely: unique, functional, safe, easy to remove, to promote the benefits of the products and to strengthen the brand (figure 2).

The packaging is part of the Food Contact Materials (FCMs) group, which should not affect the health of consumers or alter the quality of the products.

According to the specialized literature, the materials intended for contact with food have been presented in different marketing contexts:

- as marketing instruments mix-Seven $\mathrm{P}=$ Product, Prices, Promotion, Place, Packaging, Positioning, People;

- as a link element between production, price, distribution, promotion;

- as a way of expressing the functions and values of packaging in relation to the needs and requirements of consumers;

- as an element in the context of the strategy of a product;

- as a component part of a promotion strategy;

- as a source of emotions and experience for consumers;

- as an education and information platform for consumers.

Packaging and goods form a system that generates interdependent relationships that are established between the component elements of the system.

The packaging will physically protect the product and will also act as a barrier against microbiological or chemical contamination, the packaging itself should not be a source of contamination of the packaged product.

Materials intended for contact with food must meet a variety of requirements. Most importantly, they must be non-toxic and chemical resistant to legal requirements. In addition, it must have a low permeability to gases, vapours and liquids, resistance to perforation,

some transparency, low costs, good processability and biodegradation capacity.

The current trends noted in the conception of packaging and packaging methods are:

- reducing the consumption of raw materials, materials and energy;

- increasing the preservation life of the products;

- enhancing the performance of the packaging by combining the manufacturing materials;

- facilitating the reintegration of packaging in the post-consumption stage into the environment.

\section{TEXTILE PACKAGING - REQUIREMENTS AND PERFORMANCE}

The materials intended for contact with food can be considered as standalone products or as part of a different product, their importance is reflected both in the performance of the functions and in the decisionmaking process regarding the purchase by consumers.

The magnitude and complexity of the socio-economic context in the food contact sector requires finding additional ways to adapt. In this context, the textile sector, respectively the field of technical textiles, through the potential of the functionalities, can make a special contribution to achieving a level of coherence between the field of functionalized materials destined for food packaging - environment - consumer health - free movement of products - efficient functioning of the internal market.

Technical textiles, a modern concept in the textile field, can be defined generically: industrial textiles/ functional textiles/hi-tech textiles/textiles of the future, and are considered as change factors for all economic, social and infrastructure fields and are characterized by:

- Alternative materials: lightweight, flexible, soft (multi/inter) functional, durable.

- A wide range of raw materials: processes, products and applications.

- New technologies: flexible, continuous, versatile.

- Reliable, multifunctional, cost-effective, functional components, parts of larger systems and technological solutions oriented towards the user.

- Positive trend to increase the consumption of unconventional textile structures. 
The global technical textiles market is expected to grow from $\$ 176.83$ billion in 2018 to $\$ 220.37$ billion by 2022 with a compound annual growth rate (CAGR) of $5.89 \%$ [9].

Among the factors that determine this growth, we can mention:

- New areas of application;

- Modifying consumer requirements;

- The multifunctional character of the technical textile properties;

- New government regulations;

- Climate change and global warming.

The group of technical textiles "PACKTECH", the important branch of the group of technical textiles, includes all packaging materials for industrial, agricultural, consumer goods and other products and can be defined by the formula [10].

$$
\text { Packaging }=(\text { Functions } / \text { Costs }) * \text { Service }
$$

The food packaging market is projected to reach a value of $\$ 305,955.1$ Million by 2019 and Asia-Pacific market is projected to grow at the highest CAGR during forecasted period (figure 3).

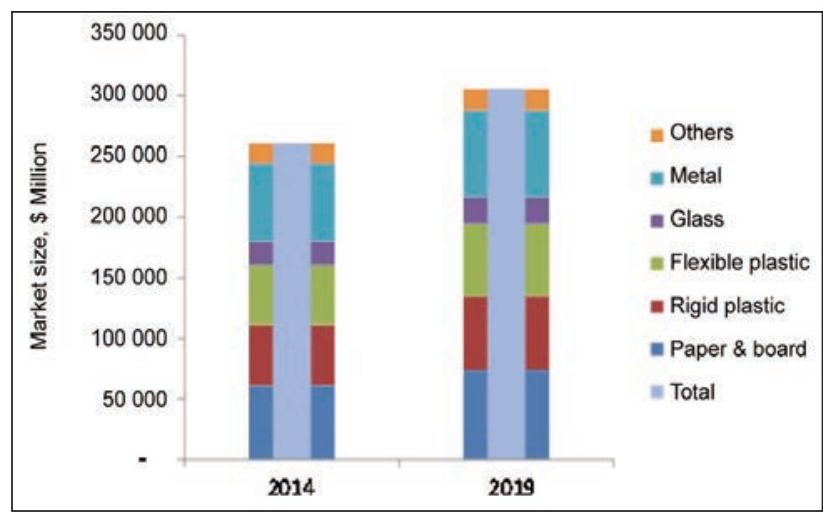

Fig. 3. Food Packaging Market Size, by Material, 2014 vs. 2019 (\$Million)/others (Wood and textile) [11]

The textile materials for packaging consumer products mainly include [12]:

- Flexible Intermediate Bulk Containers big bags (FIBC).

- Laundry bags and other bulk packaging products.

- Sacks for storage, etc.

- Twine and string for tying packages, etc. (excludes agricultural applications).

- Non-paper tea bags and coffee filters.

- Food soaker pads.

- Net packaging for storing, packing, transporting, retailing foodstuffs, toys.

- Soft luggage.

Products included in this category can be made from fabrics or unconventional textiles - non-wovens of natural fibers (cotton, organic cotton, jute, hemp, wool) or chemical fibers/yarns (polypropylene, HDPE polyethylene).

Woven sacks (except FIBC) represent about $50 \%$ of the consumption of technical textiles within Packtech, followed by bags with a share of about $30 \%$ [10].
The progression of packing demand is influenced by a wide range of factors, from year to year. While the economy plays a central role in influencing the market, there are a number of other factors that can be seen as having a direct impact or an indirect influence on the demand for packaging. These include:

- aging of the population;

- the people tendency to organize in small households;

- increasing demand for convenience;

- awareness of the importance of health among consumers:

- the modification of the lifestyle, among the consumers, increasingly poor;

- the requirements for shelving differentiation;

- environmental care;

- development of new materials;

- smaller size of food packaging;

- adopting new regulatory requirements regarding the recycling of packaging.

The growing need for reusable packaging and containers opens up new opportunities for textile products in this market.

Among the main factors underlying the choice of the optimum packaging can be mentioned [13]:

- the characteristics of the product being packaged;

- the transport and handling conditions, with the influences and the requests that intervene;

- the characteristics and aptitudes of the packaging materials;

- method of packing;

- expenses incurred in the production and transport of packaging.

All materials that come into contact with food fall within the scope of two European legislative acts, which "ensure the efficient functioning of the internal market of materials and objects intended to come in direct or indirect contact with food and provide the basis for ensuring a high level of protection of human health and consumer interests".

Regulation (EC) no. 1935/2004 on materials and objects intended to come into contact with foodstuffs, also known as the Framework or FCM Regulation establishes general requirements for all FCMs.

Regarding textile packaging, the regulation provides (table 3) [15].

Regulation (EC) no. 2023/2006 on good manufacturing practices for materials and objects intended to come into contact with food, also known as GMP Regulation.

The architecture of the respective legislation also includes:

- specific directives/regulations regulating some of the special materials and articles listed in the framework regulation.

- directives/regulations regarding the individual substances or groups of substances used in the manufacture of FCM.

The functions that must be fulfilled by the packaging, including the textile ones, are defined taking into account the preservation - protection, handling - 


\begin{tabular}{|c|c|}
\hline \multicolumn{2}{|r|}{ FCM TYPE VS GENERAL MEASURES } \\
\hline FCM type & General measures \\
\hline Textiles & $\begin{array}{l}\text { Regulation (EC) no. } 1935 / 2004 \\
\text { Harmonized EU legal framework that sets out the general principles on the safety and inertia of all } \\
\text { FCMs. } \\
\text { Principles: } \\
\text { - not to release their constituents in food products to an extent harmful to human health; } \\
\text { - not to produce an unacceptable change in the composition, taste and smell of food; } \\
\text { Requirements: } \\
\text { - special rules for active and intelligent materials (they are not inert by their design); } \\
\text { - competencies to adopt additional EU measures for some specific materials (for example, for plastics); } \\
\text { - the procedure for conducting safety assessments for substances used in the manufacture of FCMs, } \\
\text { which involves the European Food Safety Authority; } \\
\text { - labelling rules, including an indication of use (e.g. a coffee machine, a bottle of wine or a tablespoon) } \\
\text { or by reproducing the symbol; } \\
\text { - compliance documentation and traceability. }\end{array}$ \\
\hline
\end{tabular}

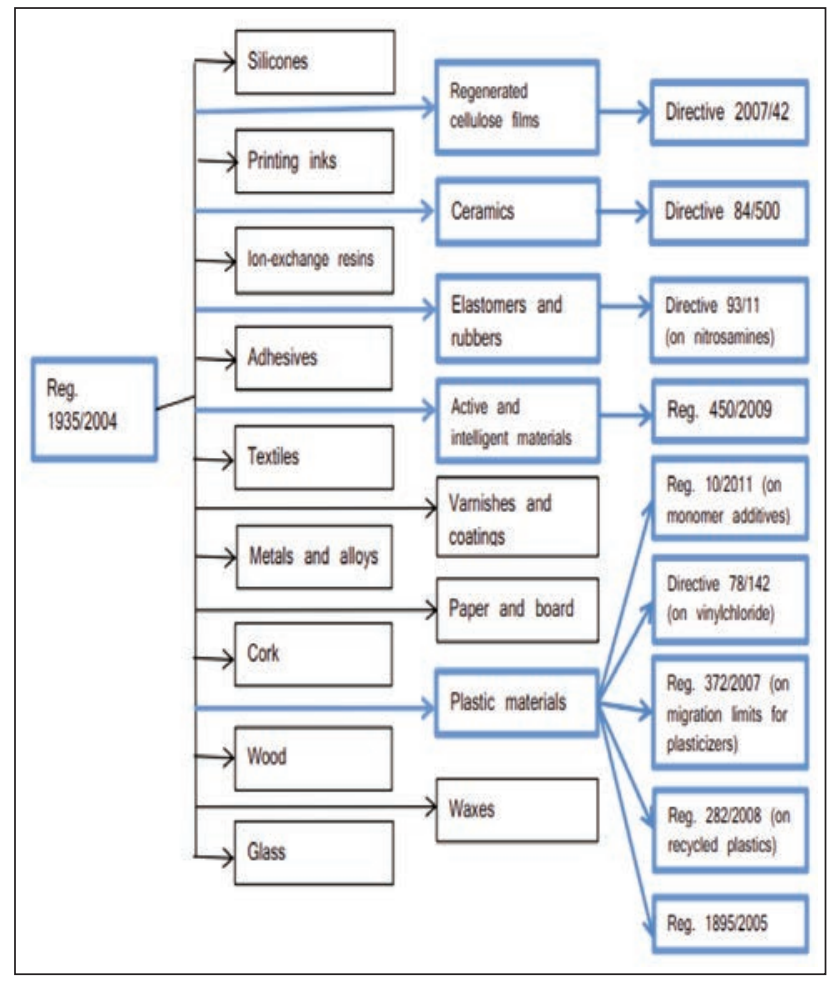

Fig. 4. Regulation (EC) No 1935/2004 [14]

storage of the products as well as the information of the consumers (table 4) [16-18].

In April 2019 the groups [19] from the civil society published 5 principles that the EU must take into account in the field evaluation activity, respectively:

- a high degree of protection of human health;

- special attention to the presence of chemicals in materials and articles that come into contact with food;

- an effective implementation;

- application of the concept of circular economy;

- transparency and participation.

Currently, Romania is in an important moment when it must adopt a strategic position towards the challenges and opportunities of wide scope. In this respect, Romania must maximize the favourable global and European trends, as well as its own competitive advantages.

In this context, the textile sector, respectively the field of technical textiles, through the potential of functionalities, can make a special contribution to achieving a level of coherence between the field of functionalized materials intended for food packaging - environment - consumer health - free movement of products efficient functioning of the internal market.

\section{CONCLUSIONS}

- The packaging must be studied both as a product - packaging system and as a distinct part which is often the determining factor in the decision to purchase the product. Product analysis in relation to the environment/man/equipment is very useful for new products.

- When choosing the materials that underlie the production of packaging in general, and textiles in particular, a basic criterion is to ensure the requirements of the product protection function, respectively:

- Protection against physical factors, of which it is worth mentioning the light protection that can cause discoloration and degradation of the goods (photochemical reactions, colour alteration, loss of vitamins.

- Chemical protection refers to the protection of products against certain aggressive chemicals. For this purpose the packaging plays the role of barrier: in the transfer of gas from the outside to the inside of the packaging; against volatile substances, which may cause alteration of the organoleptic properties of the products; at the transfer of gases from the inside to the outside, in order to avoid losing the specific flavours of the product; dehydration of the product; the loss of the gaseous mixture that was introduced inside the package in order to preserve the product.

- Protection against biological factors: avoiding contamination of products; limiting the gas exchanges susceptible to the appearance and 


\begin{tabular}{|c|c|}
\hline \multicolumn{2}{|r|}{ THE FUNCTIONS OF PACKAGES } \\
\hline $\begin{array}{l}\text { The functions } \\
\text { of packages }\end{array}$ & Protection \\
\hline $\begin{array}{c}\text { Product } \\
\text { preservation } \\
\text { and protection } \\
\text { function }\end{array}$ & $\begin{array}{l}\text { The protection function is summarized in three particular aspects as follows: } \\
\text { - protecting the product from the action of internal and external factors; } \\
\text { - protecting the environment against the toxic nature of some products; } \\
\text { - intact preservation of the quality of the goods at the direct product-packaging contact (avoiding the } \\
\text { negative influence by the packaging of the product quality); } \\
\text { - chysical factors: mechanical actions, light, temperature, pressure; } \\
\text { - biological factors: (microorganisms, insects etc.). } \\
\text { When choosing the material from which the packaging is made, the following is taken into account: } \\
\text { - the nature of the product to be packed (aggregation state, physico-chemical and biological prop- } \\
\text { erties); } \\
\text { - own chemistry (choosing packaging materials that are chemically inert to the product and the envi- } \\
\text { ronment). }\end{array}$ \\
\hline $\begin{array}{l}\text { The handling, } \\
\text { transport and } \\
\text { storage/ } \\
\text { rationalization } \\
\text { function }\end{array}$ & $\begin{array}{l}\text { Rationalization and promotion of typical, modular packaging to facilitate the operations of handling, } \\
\text { transport and storage, the use of depreciation and fixing materials, are aspects that demonstrate the } \\
\text { rationalization function: } \\
\text { - handling the product by shape, volume; } \\
\text { - adapting the packaging to the norms and the specific means of transport; } \\
\text { - taking over the pressure during the stacking operation. }\end{array}$ \\
\hline $\begin{array}{l}\text { The function of } \\
\text { information and } \\
\text { sales promotion }\end{array}$ & $\begin{array}{l}\text { The packaging has an important communication function when presenting and selling the products, } \\
\text { since most of the products sold packaged it is obvious that the packaging also has a dual role of } \\
\text { promoting the sale and carrying the information to the consumer. The packaging represents an inter- } \\
\text { face with which the consumer comes in direct contact, which is why the packaging has to be thought } \\
\text { out to attract the buyers and to trigger the act of purchase, the packaging has also been called the } \\
\text { 'silent seller' of the product. The elements that contribute to the fulfilment of the function of promoting } \\
\text { the sales and informing the consumer that they have the packages are: the way of manufacture, the } \\
\text { system of marking and labelling, but especially the aesthetics of the packaging, that is to say the } \\
\text { aspects regarding the form, the colour and the harmony, the graphics of the packaging. These } \\
\text { elements need to be harmonized to attract the attention of the buyer. The packaging must ensure a } \\
\text { positive visual impact. Thus, in order to have the chance to be bought by the consumer, a product } \\
\text { must first be seen and be able to be identified from all the products on the shelf: } \\
\text { - the product-consumer interface; } \\
\text { - identifying and presenting the product, informing the buyers, creating a positive attitude towards } \\
\text { the product, changes in the mind-set and habits of the buyer, communicating with the customer; } \\
\text { - identifying the product and its brand, presenting the characteristics and conditions of use; } \\
\text { - creating a favourable image of the product. }\end{array}$ \\
\hline
\end{tabular}

development of pathogenic germs; ensuring sealing of microbial germs, sterilization conditions for products that require this treatment.

- The present packages of textile materials have a limited use, due to some disadvantages, respectively:

- Constitutes a favourable environment for the development of microorganisms.

- They are attacked by rodents, insects and do not resist fire.

- Products in this category can be made from unconventional fabrics or textiles - non-woven from natural fibers (cotton, organic cotton, jute, hemp, wool) chemical fibers/yarns (polypropylene, HDPE polyethylene, etc.).

- The objectives of the testing activity of the textile structures destined to the packaging of the products are: evaluation of the basic and functional characteristics of the product and the prediction of the performances during the use. The information obtained can be used in the research-development activity, the selection of the raw material base, the development of processes, control activities, quality control, production testing, product failure analysis, comparing tests, compliance with legal regulations.

- The new textile materials, which bring functionalities and superior levels of performance in the field of packaging, are based on: innovative technologies, natural organic fibers, recyclable, biodegradable, unconventional mixtures of natural fibers, structural eco-design methods, up-cycling techniques, active elements (traceability devices, indicators, sensors).

- Smart (active and intelligent) textile materials for food contact can and should change the quality of life, and just as all materials must be a source of sustainability, be recyclable, ensure safety and quality, take into account the consumer experience, to provide as much information as possible, to contribute to the reduction of food waste, to be connected with the respective brands.

\section{ACKNOLEDGEMENT}

This work was supported by a grant of the Romanian Research and Innovation Ministry, through Sectorial Plan, contract no. 3PS/2019. 


\section{REFERENCES}

[1] ECOSIGN, Food Packaging, Available at: http://www.ecosign-project.eu/food-packaging/ [Accessed November 2019]

[2] Bazgă, B., Chelmu, S.S., Securitatea alimentară: Potențialul agricol, componentă a securității naționale a României, 2013, Available at: https://intelligence.sri.ro/securitatea-alimentara-potentialul-agricol-componentasecuritatii-nationale-romaniei/ [Accessed November 2019]

[3] Purcarea, C., Popa, A., et al., Rolul ştiinţelor şi tehnologiilor în siguranta alimentara în corelaţie cu alimentaţia sănătoasă şi rolul său în prevenirea unor boli metabolice, ISBN 978-3-9503145-1-9, Vienna, 2012

[4] Pro Alimente-dincolo de ambalaj, Factori care pot afecta inlocuitatea produselor alimentare, 2016, Available at: http://proalimente.com/inocuitatea-produselor-alimentare/ [Accessed November 2019]

[5] Hojda, A., Siguranta si securitatea alimentara, Available at: https://www.academia.edu/10154491/ESEU_ siguranta_si_securitatea_alimentara [Accessed November 2019]

[6] QReferat, Nutrienti alimentari, Available at: http://www.qreferat.com/referate/alimentatie/Nutrienti-alimentari 248.php [Accessed November 2019]

[7] Roberge, D., How To Develop Your Ideal Packaging Strategy, 2018, Available at: https://www.industrial packaging.com/blog/how-to-develop-your-ideal-packaging-strategy [Accessed November 2019]

[8] Learn Marketing, 2019, Available at: https://www.learnmarketing.net/packagingstrategies.htm [Accessed November 2019]

[9] Technical Textile Market, Technical Textile Market by Material (Natural Fiber, Synthetic Polymer, Metal, Mineral, Regenerated Fiber), by Process (Woven, Knitted, Non-woven), by Application (Mobiltech, Indutech, Protech, Buildtech, Packtech), and Region - Global Forecast to 2022, 2018, Available at: https://www.marketsand markets.com/Market-Reports/technical-textile-market-1074.html [Accessed November 2019]

[10] Textile Learner, Advantages and Uses of Textile Packaging Material, Available at: https://textilelearner.blogspot. com/2013/01/packtech-textile-packaging-material.html, [Accessed November 2019]

[11] MarketsandMarkets, Food Packaging Market by Material (Paper \& Board, Plastic, Glass, Metal), Type (Rigid, SemiRigid, Flexible), Application (Dairy, Bakery, Confectionery, Convenience Foods, Fruits, Vegetables, Meat, Sauces, Dressings) - Global Trends \& Forecast to 2019, 2014, Available at: https://www.marketsandmarkets.com/MarketReports/food-packaging-market-70874880.html, [Accessed November 2019]

[12] Dirgar, E., Oral, O., Packing Textiles and Their Application Areas, XIII ${ }^{\text {th }}$ International Izmir Textile and Apparel Symposium, April 2-5, 2014

[13] Definirea şi clasificarea ambalajelor, 2017, Available at: https://conspecte.com/Merceologia-marfuriloralimentare/definirea-si-clasificarea-ambalajelor.html [Accessed November 2019]

[14] ANEC Position Paper on the implementation of the FCM legislation, 2016, Available at: http://www.anec.eu/ images/Publications/position-papers/Chemicals/ANEC-PT-2016-CEG-021.pdf [Accessed November 2019]

[15] Food Safety Authority of Ireland, Food Contact Materials, 2014, 1, Available at: file:///C:/Users/Crina/Downloads/ Food\%20Contact\%20Materials\%20FINAL\%20(2).pdf [Accessed November 2019]

[16] Cojoaca, M., Ambalarea și etichetarea mărfurilor, 2013, Available at: https://www.academia.edu/32377149/FdSM_ Tema_10._Ambalarea_\%C8\%99i_etichetarea_m\%C4\%83rfurilor [Accessed November 2019]

[17] Packaging, Available at: http://www.scritub.com/tehnica-mecanica/Ambalarea3363176.php [Accessed November 2019]

[18] The importance of food packaging, Available on: http://www.rasfoiesc.com/business/economie/merceologie/ IMPORTANTA-AMBALAJULUI-ALIMENT91.php [Accessed November 2019]

[19] HEAL- Health and Environment Alliance, Food contact materials and chemical contamination, May 2019, Available at: https://www.env-health.org/wp-content/uploads/2019/06/Food-Contact-Materials-Briefing-Health-and-environmentAlliance-HEAL-PRINT_final-1.pdf [Accessed November 2019]

\section{Authors:}

\section{EFTALEA CĂRPUȘ, ANGELA DOROGAN, CRISTINA STROE}

National R\&D Institute for Textiles and Leather - INCDTP, Lucretiu Patrascanu Street, no. 16, 030508, Bucharest, Romania

\section{Corresponding author:}

\section{EFTALEA CĂRPUȘ}

e-mail: eftalea.carpus@incdtp.ro 


\section{Development of free fluorine and formaldehyde oil and water repellent finishes for cotton fabrics through polymerization of bio-based stearic acid with carboxylic acids}

DOI: 10.35530/IT.071.02.1731

SHARIF RABIA

AHMAD SYED WAQAS

MOHSIN MUHAMMAD

HAJI GHULAM QUTAB

RAMZAN NAVEED

\section{ABSTRACT - REZUMAT}

Development of free fluorine and formaldehyde oil and water repellent finishes for cotton fabrics through polymerization of bio-based stearic acid with carboxylic acids

This research is an attempt to develop nontoxic and sustainable oil and water repellent which is fluorine and formaldehyde free. For this purpose, stearic acid was polymerized with formaldehyde free cross-linkers, such as maleic acid and acrylic acid. Sodium hypophosphite was used as a catalyst and triethanolamine as an enhancer during the polymerization. Polymerization conditions were optimized such as temperature, time and atmosphere. The prepared recipes were then applied onto the cotton fabrics. The obtained results reveal that the finished cotton fabrics achieves good oil and water repellency, crease resistance, soil resistance, and antimicrobial properties. In addition, the surface of finished cotton fabrics was characterized via SEM, EDX, FTIR, XRD, and TGA.

Keywords: oil and water repellency, maleic acid, acrylic acid, functional textile, eco-friendly.

Dezvoltarea de finisări oleofobe și hidrofobe fără fluor și formaldehidă prin polimerizarea acidului stearic bio cu acizi carboxilici pentru țesături din bumbac

Acest studiu este o încercare de obținere a finisărilor hidrofobe și oleofobe non-toxice și durabile, care nu conțin fluor și formaldehidă. În acest scop, acidul stearic a fost polimerizat cu agenţi de reticulare fără formaldehidă, precum acid maleic și acid acrilic. Hipofosfitul de sodiu a fost utilizat în calitate de catalizator, iar trietanolamina ca agent de intensificare în timpul polimerizării. Condițiile de polimerizare au fost optimizate, din punctul de vedere al temperaturii, duratei și atmosferei. Rețetele preparate au fost apoi aplicate pe țesături din bumbac. Rezultatele au arătat faptul că țesăturile din bumbac finisate sunt hidrofobe și oleofobe, prezintă rezistență la șifonare, rezistență la murdărie și proprietăți antimicrobiene. În plus, suprafețele țesăturilor din bumbac finisate au fost caracterizate utilizând SEM, EDX, FTIR, XRD și TGA.

Cuvinte-cheie: hidrofob și oleofob, acid maleic, acid acrilic, material textil funcțional, ecologic

\section{INTRODUCTION}

Cotton is one of the most abundantly available fibrous biomass materials and has been extensively used in many textile areas, as it exhibits various attractive properties [1] such as hydrophilicity, wearing comfort, breathability [2] and good mechanical strength [3]. However, it lacks oil and water repellency. To meet the demand of customers several chemical finishes are available in the market. These chemical finishes can impart function properties to the cotton fabric such as flame retardancy [4-5], ultraviolet protection [6], antibacterial activity [7], corrosion inhibition, crease recovery [8], self-cleaning properties [9], as well as water and oil repellency [10]. In order to make cotton fabric oil and water repellent its surface energy should be lowered by application of chemical finishes such as silicone repellents [11], fluorocarbon-based repellents [12], paraffin repellents [13] and polyurethanes-based repellents [14]. Most of these finishes are either expensive, noxious, nondurable or less efficient.
Among them, fluorocarbon finishes based on C8 chemistry are most attractive as they significantly lower the surface energy of the cotton fabric $(\leq 18$ dynes/cm) to impart excellent oil and water repellency [15]. However, due to their adverse effect on the environment and potential toxic effect on human, there is an urgent need for fluorine-free oil and water repellent alternative. Moreover, C8 based perfluorinated and polyfluorinated chemicals (PFCs) are part of 11 priority chemicals that are banned to use internationally in the textile and leather process industry [16].

Nowadays, emergent research is focused on non-fluorine, eco-friendly oleophobic and hydrophobic finishes. An alternative to fluorinated compounds is long alkyl chain compounds [17]. Use of stearic acid to impart hydrophobicity has been reported in the literature. Stearic acid is an ecological, long-chain fatty acid which is used as a water repellent finish. Despite this, it lacks durability as well as higher concentration is required for effective results. In addition, it only repels water but not oil. Stearic acid is also used to 
impart hydrophobicity to cotton and non-cotton fabric as reported in literature. Cotton fabric can be made more hydrophobic by treating it with titanium dioxide [18], silica nanoparticles [19], and zinc hydroxide [20] followed by dipping in stearic acid solution. However, the washing durability of the coating was not good. Hydrophobicity of non-cotton fabric such as jute fibers [21] and polyester fabric [22], can also be increased by stearic acid modification process. However, the researchers did not present the durability of coating in terms of washing. Hydrophilic behavior of recycled jute fiber treated with $\mathrm{TiO}_{2}$ solutions has been shifted to hydrophobic by immersing it in stearic acid solution. There was also increase in the contact angle of the treated fabric [23]. However, stearic acid is nondurable and exhibit only water repellency.

To enhance the functional properties, durability and performance of cotton, different techniques have been introduced. Crosslinking of cellulose, with certain compounds through a chemical reaction to bridge cellulose chain for effective performance and durability is one of them [24]. Depending on chemical structure, crosslinkers are further classified as formaldehyde-based and formaldehyde-free crosslinkers. Formaldehyde-based crosslinkers dominated in past as they provide outstanding wrinkle resistance at low price but on the other hand, they reduce fabric strength, increases stiffness and release formaldehyde which is a lethal compound for human as it is now declared as confirmed carcinogenic [25]. Therefore, formaldehyde-free cross-linkers like polycarboxylic acids (PCAs) are getting more popular as they can increase washing durability and wrinkle resistance of cotton fabric without involving formaldehyde [26]. The reaction mechanism of crosslinking of PCAs with cotton is carried out in two steps: dehydration of two adjacent carboxyl groups forms cyclic anhydride, and then esterification reaction takes place between cellulose and intermediate anhydride to form ester bond [27-28].

Among all effective PCAs, BTCA is one of the most effective crosslinkers for cotton but it causes considerable damage to mechanical properties of cotton fabric and it is very expensive [29]. Citric acid is a biobased cross-linker and it has been reported to crosslink cotton fabric [30] but its application is inhibited due to its yellowing effect [31]. Therefore, the use of cost-effective polycarboxylic acids such as maleic acid (dicarboxylic acid) [32] and monocarboxylic acid such as acrylic acid has also been reported in the literature [33]. However, carboxylic acid does not impart any oil and water repellency on their own.

Therefore, in this research stearic acid was polymerized with maleic acid and acrylic acid, in the presence of catalyst SHP and triethanolamine TEA under various polymerization conditions, temperature and time. The newly developed finish recipes were applied onto the cotton fabric and treated fabric performance were also assessed.

\section{EXPERIMENTAL SECTION}

Materials

Scoured, bleached and $100 \%$ pure cotton fabric was used without any other finishing processes. Lab grade stearic acid (SA), maleic acid (MA), acrylic acid (AA), sodium hypophosphite monohydrate (SHP), triethanolamine (TEA) and Isopropyl alcohol (IPA) were purchased from Sigma Aldrich. Lab grade distilled water was used as a solvent. All chemicals were used directly without any further purification.

\section{Chemical and fabric preparation}

The polymerization reaction was carried out in a temperature and time-controlled polymerization reactor coupled with a stirrer and vacuum pump. A measured amount of fluorine-free water repellent monomer; stearic acid along with non-toxic and formaldehydefree crosslinker such as maleic acid and acrylic acid in the presence of catalyst SHP and enhancer TEA were fed to the polymerization reactor. Optimization of the operation parameter was carried out. Finally, the reaction was carried out at optimum condition of $160^{\circ} \mathrm{C}$ for 3 hours in vacuum conditions for maleic acid and at $200^{\circ} \mathrm{C}$ for 2 hours for acrylic acid. The obtained recipes were diluted with Isopropyl alcohol and water in two different beakers. The pad-dry-cure method was used to apply finishes onto the fabric. Two roll laboratory padder with $70 \%$ pick up was used to apply the recipe onto the fabric. After that, cotton fabric was dried at $100^{\circ} \mathrm{C}$ for 180 seconds and cured at $180^{\circ} \mathrm{C}$ for 120 seconds. Prior to any testing, conditioning of all test sample was carried out for 24 hours at $20 \pm 5^{\circ} \mathrm{C}$ and $65 \%$ of relative humidity.

\section{Evaluation of fabric properties}

AATCC and ISO test standard methods were used to evaluate the easy-care properties of the treated fabric. For water repellency, AATCC Test Method 193 and AATCC Test Method 22 was used. For oil repellency, AATCC Test Method 118 was employed. To find the crease recovery angle and soil resistance of treated fabric, AATCC Test Method 66-2003 and AATCC Test Method 130 were used respectively. AATCC Test Method 147 was used to investigate the antibacterial properties of the fabric. British Standard BS EN ISO 13934-1 and British Standard BS EN ISO 4674 were used to determining tensile strength and tear strength of coated fabric respectively. To probe air permeability and shrinkage of treated fabric, British Standard BS EN ISO 9237 and AATCC Test Method 135 were performed respectively. The durability of the coating was inspected by washing method IS0 105-C10:2006.

\section{CHARACTERIZATION TO VALIDATE THE RESULTS}

\section{Contact angle}

DSA 30 was used to find wet contact angle (WCA) of modified and un-modified cotton fabric. A camera was attached with a computer interface to capture 
and assess the shape and contact angle of drop placed on the fabric. The contact angle of control fabric and the treated fabric was measured.

\section{FTIR analysis}

FTIR spectroscopy technique was employed to determine the degree of ester crosslinking between cellulose/stearic acid/maleic acid and cellulose/ stearic acid/acrylic acid. FTIR spectrum was recorded with a scan range of $500-2500 \mathrm{~cm}^{-1}$ and a resolution of $4 \mathrm{~cm}^{-1}$.

\section{Thermogravimetric analysis}

Thermogravimetric analysis (TGA) of samples was performed to record the mass loss during heating from $25^{\circ} \mathrm{C}$ to $600^{\circ} \mathrm{C}$ with a heating rate of $10^{\circ} \mathrm{C} / \mathrm{min}$. A NETZSCH TG 209F1 Libra (Germany) evolution analyzer was used. The sample mass of 3-5 mg was placed in an alumina crucible in the presence of air.

\section{X-ray diffraction}

The diffractogram of the samples was recorded using X'Pert Pro diffractometer (Netherland) with $\mathrm{Cu} \mathrm{Ka}$ radiation $(\lambda=0.1540 \mathrm{~nm})$ and a generator was running at $45 \mathrm{kV}$ and $40 \mathrm{~mA}$. One of the most important characteristics of cellulose that contribute to its chemical, physical and mechanical properties is its crystallinity. XRD is an analytical technique that provides information on the molecular structure of the finished fabric by measuring the crystallinity index of the samples. Segal crystallinity index was calculated based on the area of amorphous cellulose peak $A_{A M}$ and the total area of all peaks $A_{\text {TOT }}$ of diffractogram [34].

$$
C / \%=1-A_{A M} / A_{T O T}
$$

\section{SEM analysis}

The morphology of cotton fabric before and after application of polymer onto the fabric was observed by scanning electron microscope.

\section{Energy dispersive spectroscopy (EDX)}

Elemental analysis of treated and untreated cotton fabric was carried out by EDX analysis with beam's energy at $5 \mathrm{keV}$. Contents of carbon, oxygen, and fluorine on the cotton fabric surface were determined by EDX.

\section{RESULTS AND DISCUSSION}

In this research, a long-chain fatty acid, stearic acid is polymerized with crosslinkers such as maleic acid and acrylic acid to impart hydrophilicity and oleophobicity to the cotton fabric. The behavior of stearic acid as oil and water repellent was observed by applying it on the cotton fabric without any polymerization. The solution of stearic acid was made in water and an organic solvent Isopropyl alcohol. Stearic acid was only fairly soluble in water at a higher temperature range from 80 to $90^{\circ} \mathrm{C}$ with zero oil and water repellency rating. However, water repellency rating of "2" was achieved when $15 \%$ of stearic acid was dissolved in Isopropyl alcohol, as shown in table 1. The

Table 1

WATER AND OIL REPELLENCY RATING OF THE COTTON FABRIC TREATED WITH STEARIC ACID AND CROSSLINKERS WITHOUT POLYMERIZATION

\begin{tabular}{|c|c|c|c|c|c|c|c|}
\hline Sample & $\begin{array}{l}\text { Oil and } \\
\text { water } \\
\text { repellent }\end{array}$ & Cross-linker & $\begin{array}{c}\text { Catalyst } \\
\text { (SHP) }\end{array}$ & $\begin{array}{c}\text { Enhancer } \\
\text { (TEA) }\end{array}$ & Solvent & $\begin{array}{l}\text { Water } \\
\text { repellency } \\
\text { rating }\end{array}$ & $\begin{array}{l}\text { Oil repellency } \\
\text { rating }\end{array}$ \\
\hline $\begin{array}{c}\text { Recipe A1 } \\
\text { (Control fabric) }\end{array}$ & - & - & - & - & - & w & w \\
\hline A2 (Nuva-3585) & $3 \%$ & - & - & - & $\mathrm{H}_{2} \mathrm{O}$ & 8 & 5 \\
\hline A3 & $1 \% \mathrm{SA}$ & - & - & - & $\mathrm{H}_{2} \mathrm{O}$ & $w$ & w \\
\hline A4 & $3 \% \mathrm{SA}$ & - & - & - & $\mathrm{H}_{2} \mathrm{O}$ & w & w \\
\hline A5 & $5 \%$ SA & - & - & - & $\mathrm{H}_{2} \mathrm{O}$ & w & w \\
\hline A6 & - & $3 \% \mathrm{MA}$ & - & - & $\mathrm{H}_{2} \mathrm{O}$ & w & w \\
\hline A7 & - & $3 \% \mathrm{MA}$ & - & - & IPA & w & w \\
\hline A8 & - & $3 \% \mathrm{AA}$ & - & - & $\mathrm{H}_{2} \mathrm{O}$ & w & w \\
\hline A9 & - & $3 \% \mathrm{AA}$ & - & - & IPA & w & w \\
\hline A10 & - & - & - & $3 \%$ & $\mathrm{H}_{2} \mathrm{O}$ & w & w \\
\hline A11 & $1 \% \mathrm{SA}$ & - & - & - & IPA & 2 & w \\
\hline A12 & $3 \%$ SA & - & - & - & IPA & 2 & w \\
\hline A13 & $5 \%$ SA & - & - & - & IPA & 2 & w \\
\hline A14 & $15 \% \mathrm{SA}$ & - & - & - & IPA & 2 & w \\
\hline A15 & $25 \%$ SA & - & - & - & IPA & 3 & w \\
\hline A16 & $30 \%$ SA & - & - & - & IPA & 3 & w \\
\hline $\mathrm{A} 17$ & $3 \%$ SA & $5 \% \mathrm{MA}$ & $5 \%$ & $5 \%$ & IPA & 2 & w \\
\hline A18 & $3 \% \mathrm{SA}$ & $5 \% \mathrm{AA}$ & $5 \%$ & $5 \%$ & IPA & 2 & $w$ \\
\hline
\end{tabular}


increased concentration of stearic acid to $25 \%$ results in a higher rating of " 3 " for water repellency. Further increase in the concentration of stearic acid does not affect water repellency rating. The solution of maleic acid and acrylic acid in water and Isopropyl alcohol showed zero oil and water repellency rating. It clearly indicates that carboxylic acid on their own cannot impart any oil and water repellency.

Effect of operational parameters on oil and water repellency rating

Effect of the selection of monomers on water and oil repellency rating

Combination of stearic acid with crosslinker maleic acid or acrylic acid in the presence of catalyst SHP and enhancer TEA under vacuum conditions exhibit water repellency rating of 4 and 3 respectively as shown in table 2. Monomers were selected by performing number of experiments in vacuum condition. Results related to dosage of stearic acid, polymerization time and temperature are described in the figures 1-3.

Vacuum condition exhibited superior results as compared to atmospheric conditions due to lesser side reactions and by-products as shown in table 3 . There is an improvement of one rating of water repellency when polymerization was carried out between stearic acid and either maleic acid or acrylic acid under vacuum and non-vacuum conditions.

\section{Effect of dosage of stearic acid on water and oil repellency rating}

The concentration of stearic acid has a vital effect on water and oil repellency rating. At different concentrations of stearic acid; $11 \%, 16 \%, 25 \%$, and $50 \%$, experiments were performed to find out the optimum value. Figure 1 clearly depicted that with an increase in dosage of stearic acid up to $25 \%$, water and oil repellency rating was also increased for maleic acid for both solvents; water and Isopropyl alcohol. However, at very higher concentration of $50 \%$, the trend remained straight due to saturation effect. For acrylic acid, the same trend as that of maleic acid had been observed for water repellency rating but it exhibits zero rating for oil repellency for both solvents.

SELECTION OF MONOMERS FOR POLYMER SYNTHESIS UNDER VACUUM AT $160^{\circ} \mathrm{C}$ AND THEIR EFFECT ON OIL AND WATER REPELLENCY RATING OF COTTON FABRIC

\begin{tabular}{|c|c|c|c|c|c|c|c|c|}
\hline Sample & $\begin{array}{c}\text { Oil and water } \\
\text { repellent } \\
\text { (SA \%) }\end{array}$ & $\begin{array}{c}\text { Cross- } \\
\text { linker } \\
(\%)\end{array}$ & $\begin{array}{l}\text { Catalyst } \\
\text { (SHP \%) }\end{array}$ & $\begin{array}{l}\text { Enhancer } \\
\text { (TEA \%) }\end{array}$ & Solvent & $\begin{array}{c}\text { Polymerization } \\
\text { temperature } \\
\left({ }^{\circ} \mathrm{C}\right)\end{array}$ & $\begin{array}{c}\text { Water } \\
\text { repellency } \\
\text { rating }\end{array}$ & $\begin{array}{l}\text { Oil repellency } \\
\text { rating }\end{array}$ \\
\hline B1 & 25 & - & - & 5 & IPA & 160 & 3 & w \\
\hline B2 & 25 & $5 \% \mathrm{MA}$ & 5 & - & IPA & 160 & 3 & w \\
\hline B3 & 25 & $5 \% \mathrm{MA}$ & 5 & - & IPA- $\mathrm{H}_{2} \mathrm{O}$ & 160 & 3 & w \\
\hline B4 & 25 & $5 \% \mathrm{MA}$ & - & 5 & IPA & 160 & 2 & w \\
\hline B5 & 25 & $5 \% \mathrm{MA}$ & - & 5 & IPA- $\mathrm{H}_{2} \mathrm{O}$ & 160 & 2 & w \\
\hline B6 & 25 & $5 \% \mathrm{MA}$ & 5 & 5 & IPA & 160 & 4 & 1 \\
\hline $\mathrm{B} 7$ & 25 & $5 \% \mathrm{MA}$ & 5 & 5 & IPA- $\mathrm{H}_{2} \mathrm{O}$ & 160 & 4 & 1 \\
\hline B8 & 25 & $5 \%$ AA & 5 & 5 & IPA & 160 & 3 & w \\
\hline B9 & 25 & $5 \%$ AA & 5 & 5 & IPA- $\mathrm{H}_{2} \mathrm{O}$ & 160 & 3 & w \\
\hline
\end{tabular}

\begin{tabular}{|c|c|c|c|c|c|c|c|c|}
\hline \multicolumn{9}{|c|}{$\begin{array}{l}\text { COMPARISON OF OIL AND WATER REPELLENCY RATING OF THE FINISHED COTTON FABRIC } \\
\text { IN ATMOSPHERIC AND VACUUM POLYMERIZATION AT } 160^{\circ} \mathrm{C}\end{array}$} \\
\hline Sample & $\begin{array}{l}\text { Oil and water } \\
\text { repellent } \\
\text { (SA \%) }\end{array}$ & $\begin{array}{l}\text { Cross- } \\
\text { linker } \\
(\%)\end{array}$ & $\begin{array}{l}\text { Catalyst } \\
\text { (SHP \%) }\end{array}$ & $\begin{array}{l}\text { Enhancer } \\
\text { (TEA \%) }\end{array}$ & Solvent & $\begin{array}{c}\text { Polymerization } \\
\text { temperature } \\
\left({ }^{\circ} \mathrm{C}\right)\end{array}$ & $\begin{array}{c}\text { Water } \\
\text { repellency } \\
\text { rating }\end{array}$ & $\begin{array}{l}\text { Oil repellency } \\
\text { rating }\end{array}$ \\
\hline C1 (atm) & 25 & $5 \% \mathrm{MA}$ & 5 & 5 & IPA & 160 & 3 & w \\
\hline C2 (atm) & 25 & $5 \% \mathrm{MA}$ & 5 & 5 & IPA- $\mathrm{H}_{2} \mathrm{O}$ & 160 & 3 & w \\
\hline C3 (vac) & 25 & $5 \% \mathrm{MA}$ & 5 & 5 & IPA & 160 & 4 & 1 \\
\hline C4 (vac) & 25 & $5 \% \mathrm{MA}$ & 5 & 5 & IPA- $\mathrm{H}_{2} \mathrm{O}$ & 160 & 4 & 1 \\
\hline C5 (atm) & 25 & $5 \%$ AA & 5 & 5 & IPA & 160 & 2 & w \\
\hline C6 (atm) & 25 & $5 \% \mathrm{AA}$ & 5 & 5 & IPA- $\mathrm{H}_{2} \mathrm{O}$ & 160 & 2 & $w$ \\
\hline C7 (vacc) & 25 & $5 \%$ AA & 5 & 5 & IPA & 160 & 3 & w \\
\hline C8 (vacc) & 25 & $5 \% \mathrm{AA}$ & 5 & 5 & IPA- $\mathrm{H}_{2} \mathrm{O}$ & 160 & 3 & $w$ \\
\hline
\end{tabular}




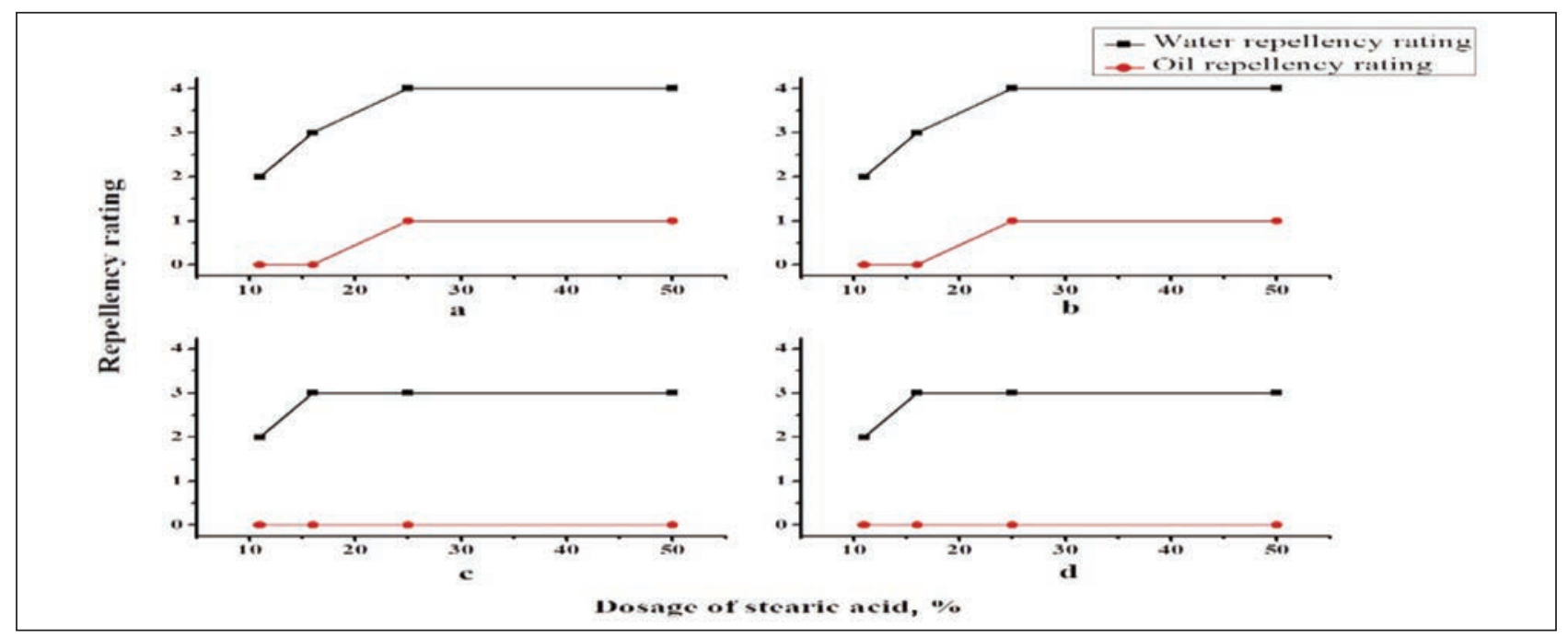

Fig. 1. Optimum dosage of stearic acid at $160^{\circ} \mathrm{C}$ with: $a-$ Maleic acid + IPA; $b-$ Maleic acid + IPA $+\mathrm{H}_{2} \mathrm{O} ; c-\mathrm{Acrylic}$ acid + IPA; $d$ - Acrylic acid + IPA + $\mathrm{H}_{2} \mathrm{O}$

\section{Effect of temperature on water and oil repellency rating}

Figure 2 reflects the influence of temperature on the oil and water repellency rating. It exhibits that as the temperature of reaction raised, water and oil repellency rating increased firstly and then decreased. At lower temperature range, crosslinking efficiency of monomers were low. Literature reports that carboxylic acid esterification reaction starts around $150^{\circ} \mathrm{C}$ and it was also reported that greater the temperature better will be the esterification. In our experimentation we also observed that after $150^{\circ} \mathrm{C}$ repellency rating was improved. The optimum value was observed at a temperature of $160^{\circ} \mathrm{C}$ for a combination of stearic acid and maleic acid and $200^{\circ} \mathrm{C}$ for a combination of stearic acid and acrylic acid.

It is important to note that at the temperature of $100^{\circ} \mathrm{C}$, very less amount of solid melted and it was difficult to apply recipe onto the fabric. As the polymerization temperature further increased after $200^{\circ} \mathrm{C}$, a viscous liquid was formed that makes the fabric very sticky thus decreasing the repellency rating. After the further increase in temperature above $200^{\circ} \mathrm{C}$ up to $450^{\circ} \mathrm{C}$, excessive evaporation started and due to this, the polymerization reactor pressure was also increased and resulted in decreased oil and water repellency rating.

\section{Effect of time on water and oil repellency rating}

Figure 3 exhibited that water and oil repellency rating was first increased and then curve remained constant as the reaction time increased. At the initial stage of the polymerization reaction, more crosslinking occurred between monomers and conversion ratio of monomers to polymer continued to increase. So, water and oil repellency rating increased with the increase of time. The optimum time of polymerization reaction was found to be 3 hours for stearic acid and maleic acid while it is 2 hours for stearic acid and acrylic acid. It is mainly due to the fact that rate of reaction between stearic acid and acrylic acid was high due to the presence of a vinyl group. Nevertheless, at a very prolonged time of 5 hours, water and oil repellency rating remained constant.



Fig. 2. Optimum temperature for polymerization of stearic acid with: $a-$ Maleic acid + IPA; $b-$ Maleic acid + IPA + $\mathrm{H}_{2} \mathrm{O} ; c-$ Acrylic acid + IPA; $d-$ Acrylic acid + IPA $+\mathrm{H}_{2} \mathrm{O}$ 




Fig. 3. Optimum time for polymerization of stearic acid with: $a-$ Maleic acid + IPA; $b-$ Maleic acid $+I P A+\mathrm{H}_{2} \mathrm{O}$; $c$ - Acrylic acid + IPA; $d$ - Acrylic acid + IPA + $\mathrm{H}_{2} \mathrm{O}$

\section{Water and oil repellency}

Commercial recipe of Nuva 3585, a C6 based fluorocarbon exhibits water repellency rating of 7 before any wash and it was reduced to 3 after 20 washes for an un-pressed sample. Nevertheless, in case of oil repellency, the fluorocarbon achieved a rating of 2 for the pressed sample after 20 washes. Sample A15, which contain alone stearic acid exhibit water repellency rating of 3 before any wash, but it became wet after 5 washes. Therefore, it can be concluded that stearic acid can only impart water repellency.

\section{Functional properties of the finished fabric}

Use of cotton fabric in various household and industrial application makes the cotton fabric among one of the most widely used fabrics. To assess the diverse application of newly developed recipes, various easy- care and performance properties were evaluated after application of finishes.

Spray test

Spray test was performed to measure the ability of the cotton fabric to repel water. Hydroxyl group present in cellulose are responsible for its water absorbency. After application of the newly developed recipes the spray rating of the treated fabric was improved. Table 4 shows that sample E6, E7, E8, and E9 were rated 70 by comparing with spotted patterns on the standard spray test rating chat. Benchmark sample A2 also rated 70 at rating chart. However, spray test rating for control fabric, sample $A 15, A 7$, and $A 9$ was 0 .

Crease recovery angle (CRA)

Crease recovery of the cotton fabric is one of the most important property which the apparel industry is

FUNCTIONAL PROPERTIES OF FINISHED AND CONTROL COTTON FABRIC AT OPTIMUM TEMPERATURE, THE DOSAGE OF MONOMERS AND TIME UNDER VACUUM CONDITION

\begin{tabular}{|c|c|c|c|c|c|c|c|c|c|}
\hline \multirow{2}{*}{ Sample } & \multirow{2}{*}{$\begin{array}{l}\text { Spray } \\
\text { test } \\
\text { rating }\end{array}$} & \multirow{2}{*}{$\begin{array}{c}\text { Contact } \\
\text { angle } \\
\text { (degree) }\end{array}$} & \multirow{2}{*}{$\begin{array}{c}\text { Air } \\
\text { permeability } \\
\text { retention } \\
(\%)\end{array}$} & \multirow{2}{*}{$\begin{array}{c}\text { Soil } \\
\text { release } \\
\text { rating }\end{array}$} & \multirow{2}{*}{$\begin{array}{c}\text { CRA } \\
(\mathrm{W}+\mathrm{F}) \\
\text { (degree) }\end{array}$} & \multicolumn{2}{|c|}{$\begin{array}{l}\text { Shrinkage } \\
(\%)\end{array}$} & \multirow{2}{*}{$\begin{array}{c}\text { Tensile } \\
\text { strength } \\
\text { retention } \\
(\%)\end{array}$} & \multirow{2}{*}{$\begin{array}{c}\text { Tear } \\
\text { strength } \\
\text { retention } \\
(\%)\end{array}$} \\
\hline & & & & & & Warp & Weft & & \\
\hline A1 (Control Fabric) & 0 & 0 & 100 & 1 & 144 & 4 & 3 & 100 & 100 \\
\hline A2 (Nuva-3585) & 70 & 145 & 71 & 3 & 165 & 3 & 2 & 84 & 81 \\
\hline A15 (SA) & 0 & 101 & 76 & 3 & 150 & 3 & 2 & 87 & 94 \\
\hline A7 (MA) & 0 & 0 & 80 & 4 & 191 & 3.2 & 1 & 80 & 75 \\
\hline A9 (AA) & 0 & 0 & 84 & 3 & 185 & 3.7 & 1.8 & 82 & 76 \\
\hline $\begin{array}{l}\text { E6 (SA+MA+ } \\
\text { SHP+TEA+IPA) }\end{array}$ & 70 & 142 & 78 & 4 & 178 & 3.1 & 1.2 & 81 & 75 \\
\hline $\begin{array}{l}\text { E7 (SA+MA+ } \\
\text { SHP+TEA+IPA+H } 20)\end{array}$ & 70 & 139 & 77 & 4 & 172 & 3.1 & 1.2 & 79 & 73 \\
\hline $\begin{array}{l}\text { E8 (SA+AA+ } \\
\text { SHP+TEA+ IPA) }\end{array}$ & 70 & 136 & 82 & 4 & 169 & 3.5 & 1.5 & 84 & 81 \\
\hline $\begin{array}{l}\text { E9 }((\mathrm{SA}+\mathrm{AA}+\mathrm{SHP}+ \\
\left.\text { TEA+ IPA+ } \mathrm{H}_{2} \mathrm{O}\right)\end{array}$ & 70 & 132 & 70 & 4 & 164 & 3.3 & 1.6 & 83 & 78 \\
\hline
\end{tabular}


looking for. Cotton fabric lacks crease resistance due to the amorphous region and weak hydrogen bonding between the chains. The crease recovery behaviour of the cotton fabric can be improved by the formation of a covalent bond with crosslinking agents. Table 4 shows the crease recovery behaviour of the treated and untreated cotton fabric. CRA has a higher value of $191^{\circ}$ and $185^{\circ}$ for maleic acid and acrylic acid respectively due to the esterification reaction between the cotton fabric and carboxylic acids. Maleic acid has higher CRA as it has two carboxylic acid groups as compared to one carboxylic group of acrylic acid. Similarly, recipes E6, E7 E8, and E9 show better crease recovery as compared to untreated cotton fabric. The commercial bench mark sample of A2 exhibited lower CRA as compared to optimized recipes of maleic acid and acrylic acid. It is quite obvious as maleic acid and acrylic acid are cross-linkers, therefore, impart superior crease recovery properties as compared to commercial oil and water repellent recipes.

\section{Air permeability}

Passage of air through cotton fabric is related to another important property which is known as air permeability. It is basically related to the comfort of clothes. The air permeability of the control fabric is set as $100 \%$. As finishes were applied onto cotton fabric, the passage of air through treated fabric decreases to a certain low value as presented in table 4 . The reduced value of air permeability for recipe E6 was $78 \%$ and for recipe E8 it was $82 \%$. However, the commercial recipe of A2 exhibited the least air permeability of $71 \%$.

\section{Soil release}

Table 4 shows that soil release of grade 1 was obtained by control fabric and it has been increased to grade 4 for samples E6, E7, E8 and E9 due to the presence of the carboxylic acid group. Soil release rating of 3 was achieved by using the benchmark commercial recipe of A2. Stearic acid and acrylic acid exhibited the soil release grade of 3 whereas maleic acid has demonstrated a grade of 4 . It is mainly due to the reason that maleic acid has two carboxylic acid groups consequently it can repel the negatively charged soils in a better way.

\section{Strength}

Tensile and tear strength retention of untreated cotton fabric was considered as $100 \%$. Typically, crosslinkers impart loss in strength due to crosslinking at the intermolecular and intramolecular level. Therefore, stress distribution among all molecules is not equal and load withstanding capacity is reduced. Samples treated with maleic acid imparted slightly more reduction in tensile and tear strength retention as compared to maleic acid. It is mainly due to greater cross-linking of maleic acid in comparison with acrylic acid recipes, table 4 .

\section{Shrinkage}

Shrinkage is associated with a change in the dimension of cotton fabric in warp and weft direction after washing. After the application of the newly synthesized finishes, shrinkage test was performed. Cotton fabric treated with acrylic acid exhibit more shrinkage in warp direction having a value of $3.7 \%$ as compared to maleic acid having a value of $3.2 \%$. Again, maleic acid being the better cross-linker will lead to lesser shrinkage as compared to acrylic acid. Sample E6 and $E 7$ both have shrinkage value of $3.1 \%$ in warp direction which was less as compared to the cotton fabric which stands at a value of $4 \%$ in warp direction as shown in table 4. Shrinkage of the commercial recipe $\mathrm{A} 2$ is more than the newly developed recipes.

\section{FTIR analysis}

The strong peaks of carbonyl stretching and ester bond formation between stearic acid, maleic acid and cellulose (E6) as well as stearic acid, acrylic acid with cellulose (E8) appeared at $1703 \mathrm{~cm}^{-1}$ and 1730 and $\mathrm{cm}^{-1}$ respectively as depicted in figure 4 . Whereas the peak at $1156 \mathrm{~cm}^{-1}$ and $1152 \mathrm{~cm}^{-1}$ corresponds to C-O stretching for sample E6 and E8 respectively. These peaks confirmed the ester linkages between recipes and cellulose. However, these ester peaks were not present for control fabric as well as for samples $\mathrm{A} 9$ and $\mathrm{A} 7$.

\section{TGA analysis}

To evaluate the thermal stability of control fabric and treated ones, thermogravimetric analysis (TGA) was performed. Figure 5 shows the TGA curves for control fabric and fabric treated with maleic acid, and fabric treated with acrylic acid respectively. Mass loss of

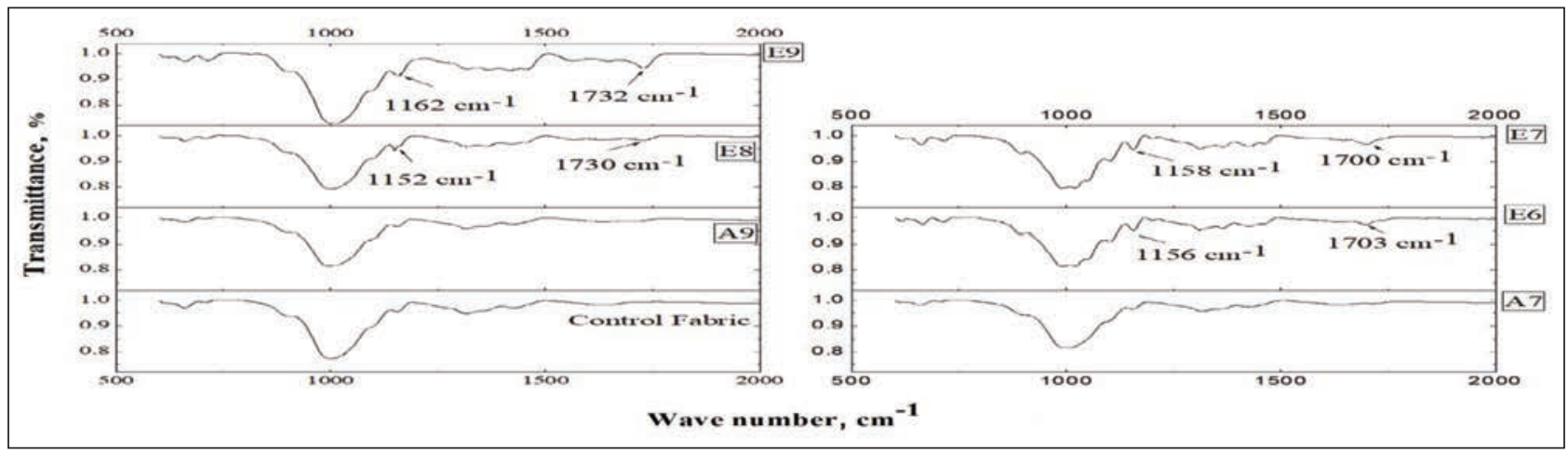

Fig. 4. FTIR spectrum of untreated control fabric and cotton fabric treated with A9, E8, E9, A7, E6, E7 


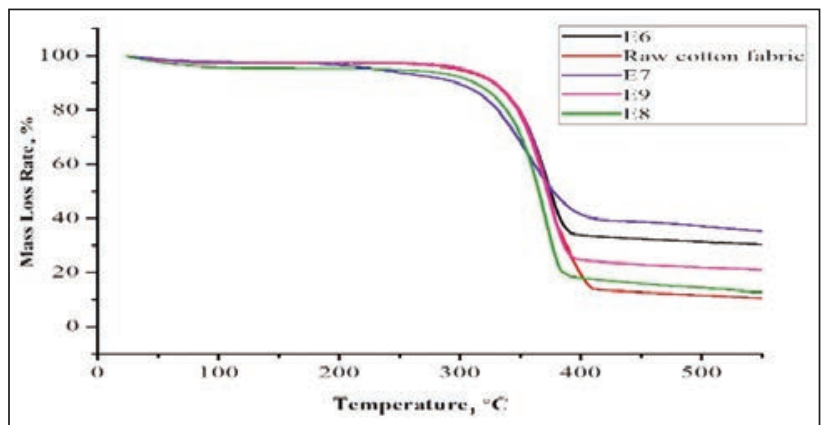

Fig. 5. TGA thermograms for control and modified cotton fabric

thermogram was divided into three regions. In the first region, the dehydration of polymer takes place and the mass loss rate is less than $5 \%$. In the second region, mass loss was due to decomposition caused by pyrolysis and in the last region, there was the conversion of remaining material to carbon residue. The melting point of cellulose is in the range of $260-270^{\circ} \mathrm{C}$. So, in TGA analysis pyrolysis of cotton fabric starts at $265^{\circ} \mathrm{C}$. Maleic acid have the melting point of $135^{\circ} \mathrm{C}$. Therefore, cotton fabric treated with E6, E7, E8 and E9 start decomposing at 261, 219, 262 and 264 respectively.

\section{XRD analysis}

Cellulose showed its diffraction peaks at $2 \theta=15.2^{\circ}$ and $22.9^{\circ}$ corresponding to 101 and 002 diffraction planes, respectively. Miller indices were used to label the peaks. Segal crystallinity index was estimated in two steps. In the first step, the subtraction of the background signal was carried out and then height ratio is considered between crystalline peak intensity and total intensity. The high degree of crystallinity was achieved with a more regular chain of finished cotton fabric and larger crystalline area. Figure 6 show the diffractogram for untreated cotton fabric and cotton fabric treated with maleic acid and acrylic acid. No considerable difference was noticed between all spectrums. Finished fabric treated with maleic acid has high crystallinity index due to the presence of two carboxyl acid groups that will form a more regular chain and better water and oil repellency as compared to acrylic acid (table 5).
CRYSTALLINITY INDEX OF UNTREATED COTTON FABRIC AND COTTON FABRIC TREATED WITH BEST RECIPES

\begin{tabular}{|l|c|}
\hline \multicolumn{1}{|c|}{ Sample } & $\begin{array}{c}\text { Crystallinity } \\
\text { Index (\%) }\end{array}$ \\
\hline A1(Control fabric) & 60 \\
\hline $\mathrm{E} 6(\mathrm{SA}+\mathrm{MA}+\mathrm{SHP}+\mathrm{TEA}+\mathrm{IPA})$ & 82 \\
\hline $\mathrm{E}$ ( $\left(\mathrm{SA}+\mathrm{MA}+\mathrm{SHP}+\mathrm{TEA}+\mathrm{IPA}+\mathrm{H}_{2} \mathrm{O}\right)$ & 76 \\
\hline $\mathrm{E} 8(\mathrm{SA}+\mathrm{AA}+\mathrm{SHP}+\mathrm{TEA}+\mathrm{IPA})$ & 78 \\
\hline $\mathrm{E} 9\left(\left(\mathrm{SA}+\mathrm{AA}+\mathrm{SHP}+\mathrm{TEA}+\mathrm{IPA}+\mathrm{H}_{2} \mathrm{O}\right)\right.$ & 75 \\
\hline
\end{tabular}

\section{SEM analysis}

The surface morphology of raw cotton, stearic acidmaleic acid-cotton and stearic acid-acrylic acid-cotton samples were studied by scanning electron microscope analysis. Figure 7 present that untreated cotton fabric surface has no coating and it was plain and smooth. However, the newly synthesized finishes E6 and E8 coating can be clearly observed on the surface of cotton fabric.

\section{EDX analysis}

Commercial recipe of $\mathrm{A} 2$, a $\mathrm{C} 6$ based fluorocarbon indicates the fluorine peak at an energy level of 0.677 $\mathrm{KeV}$ showing counts of 91 . EDX spectrum of samples A1, A15, A7, A9, E6, E7, E8 and E9 exhibited no peak for fluorine showing that control fabric and newly synthesized recipes were free of fluorinated compounds. Highest counts of carbon 669 and oxygen 550 elements can be observed in E6 having maleic acid diluted with isopropyl alcohol due to the presence of more carboxyl groups. Figure 8 showed the EDX spectrum of control fabric compared with cotton fabric coated with newly synthesized fluorinefree recipes.

\section{Contact angle}

Since the cotton fabric is hydrophilic in nature, therefore, water droplet placed on it is spread immediately as shown in figure 9, a. Modified cotton fabric with stearic acid showed contact angle of $101^{\circ}$, as stearic acid (A15) lowers the surface energy of treated cotton fabric but the coating was non-durable.
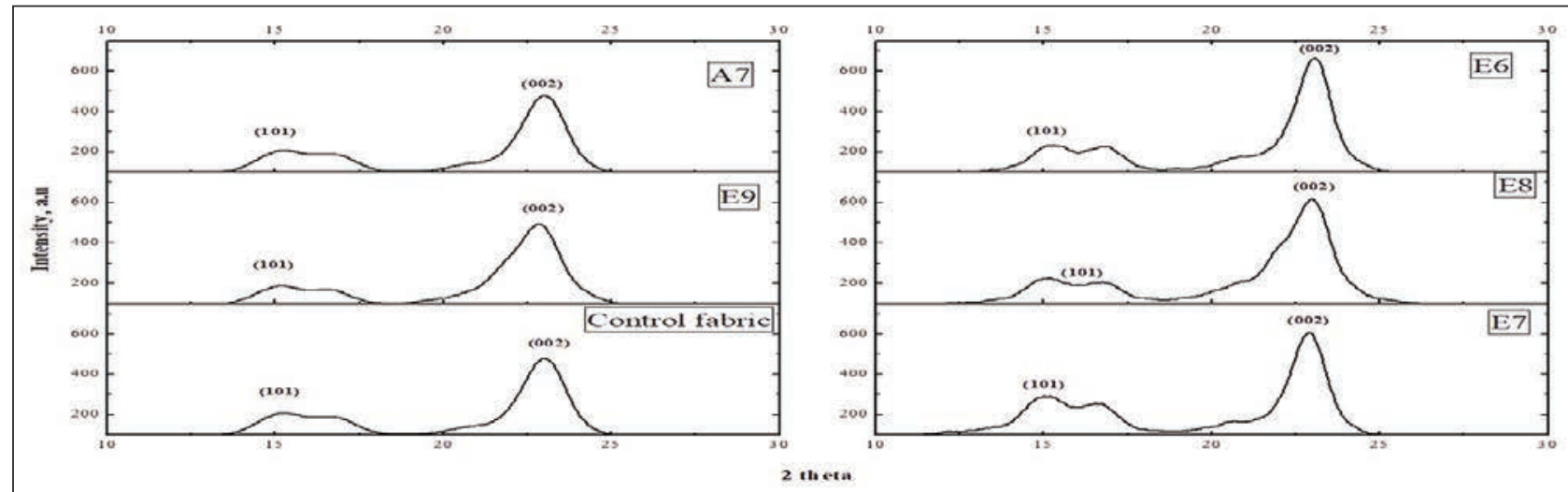

Fig. 6. XRD spectrum for control cotton fabric and modified cotton fabric with maleic acid and acrylic acid 


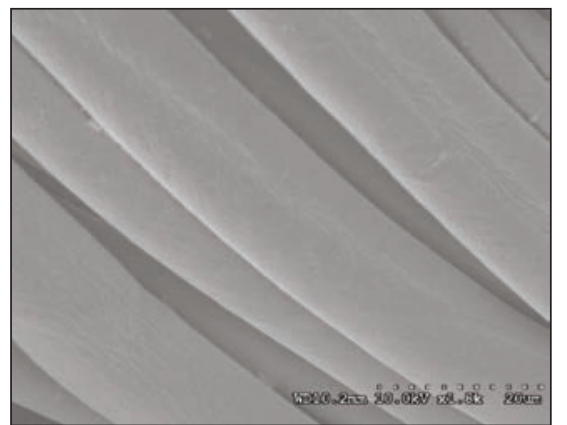

a

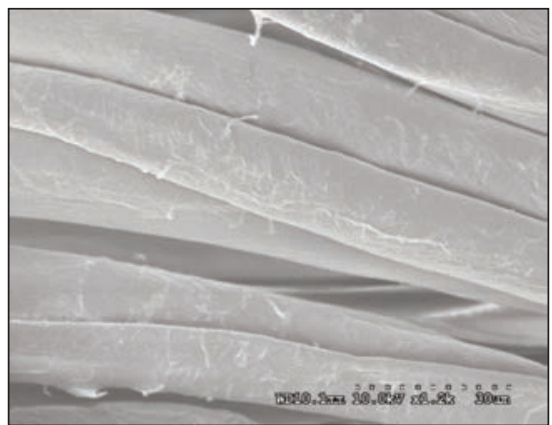

$\boldsymbol{b}$



$\boldsymbol{C}$

Fig. 7. SEM analysis of: $a$ - control fabric; $b$ - coated fabric with E8; $c$ - coated with E6 recipes


$\mathrm{KeV}$
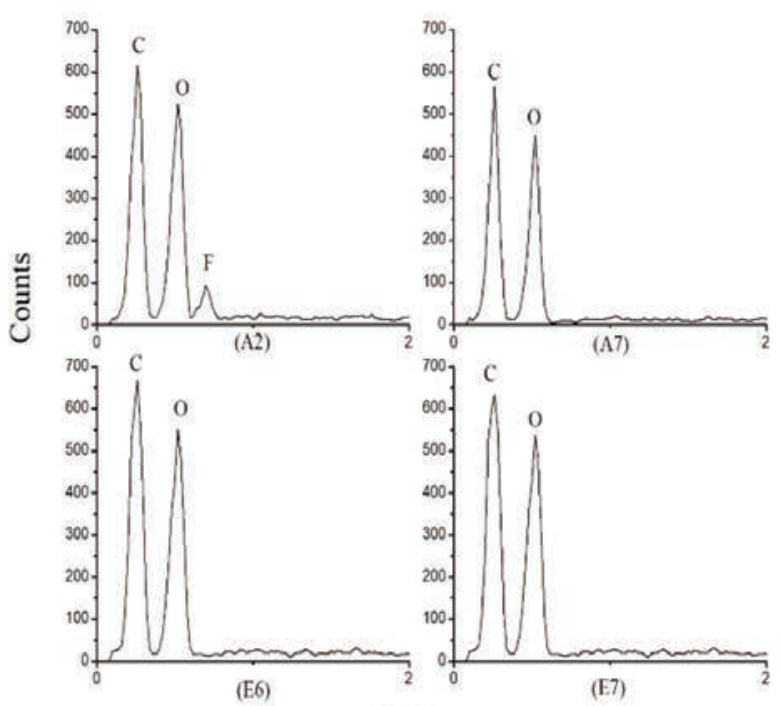

$\mathrm{KeV}$

Fig. 8. EDX spectrum for control cotton fabric and modified cotton fabric with maleic acid and acrylic acid

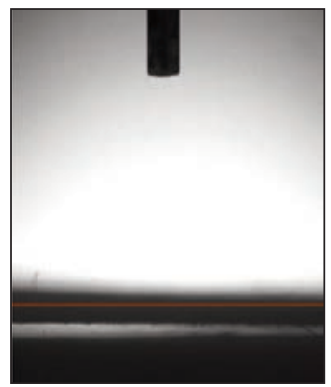

a

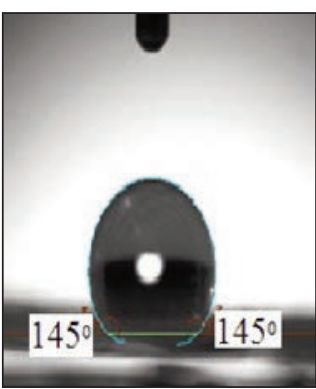

b

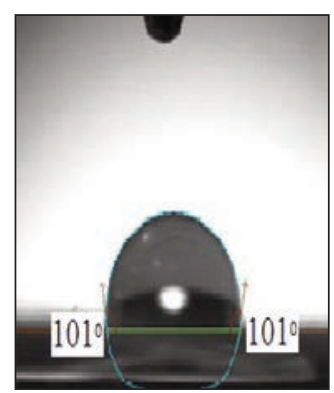

c

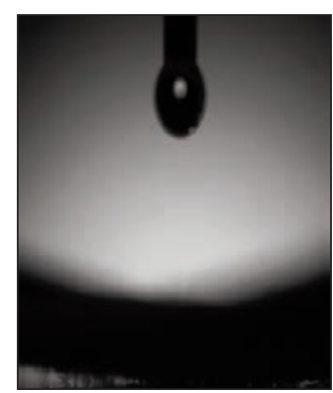

d e

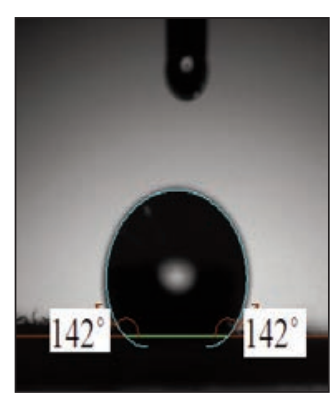

f

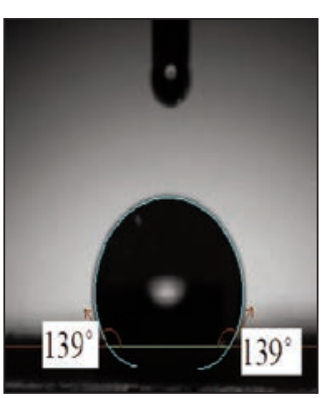

g

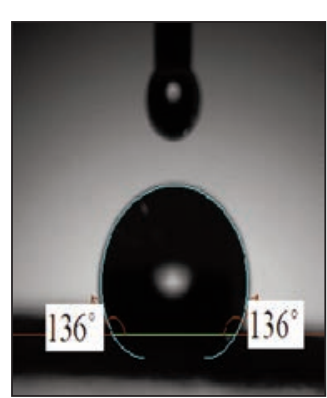

$\boldsymbol{h}$

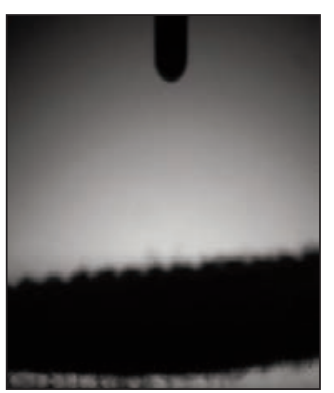

Fig. 9. Contact angles of: $a$ - control fabric; $b-\mathrm{A} 2$ (bench mark); $c-\mathrm{A} 15$ (stearic acid); $d-\mathrm{A} 7$ (maleic acid); $e-\mathrm{A} 9$ (Acryic acid); $f-\mathrm{E} 6 ; g-\mathrm{E} 7 ; h-\mathrm{E} 8 ; i-\mathrm{E} 9$ 
Crosslinkers such as maleic acid (A7) and acrylic acid (A9) showed $0^{\circ}$ contact angle when applied alone on cotton fabric. Sample E6, E7 showed contact angle $142^{\circ}$ and $139^{\circ}$ respectively due to a combination of stearic acid with maleic acid.

Incorporation of cross-linker such as maleic acid with stearic acid increases washing durability of the coating as well as contact angle as shown in table 4. Polymerization of acrylic acid with stearic acid (E8, E9) also improves washing durability of coating and contact angle. However, better and comparable results with benchmark having a contact angle of $145^{\circ}$ were obtained with maleic acid due to the presence of two carboxyl groups. The contact angle of sample E8 and E9 was $136^{\circ}$ and $134^{\circ}$ respectively.

\section{Antimicrobial potential}

Table 6 shows the antibacterial activity of different sample again $E$. coli and $S$. aureus. Raw cotton showed no antibacterial resistance, however, cotton fabric modified with maleic acid and acrylic acid exhibited antibacterial performances. Sample E6 exhibit better antimicrobial properties against grampositive and gram-negative bacteria as compared to E8 due to the presence of two carboxylic acid groups.

Table 6

INHIBITION ZONE OF SAMPLE E6 AND E8 FOR E. COLI AND S. AUREUS BACTERIA

\begin{tabular}{|l|c|c|}
\hline \multirow{2}{*}{ Samples } & \multicolumn{2}{|c|}{ Inhibition zone $(\mathbf{c m})$} \\
\cline { 2 - 3 } & E. coli & S. aureus \\
\hline A1 (control fabric) & 0 & 0 \\
\hline E6 (SA+MA+IPA) & 0.23 & 0.18 \\
\hline E8 (SA+AA+IPA) & 0.17 & 0.16 \\
\hline
\end{tabular}

\section{CONCLUSIONS}

The presented cross-linkers maleic acid and acrylic acid along with stearic acid yielded a successful synthesis of fluorine and formaldehyde-free oil and water repellent for cotton fabric. The newly polymerized recipes application onto the cotton fabric lead to improved crease-resistance, antimicrobial properties, soil release properties, contact angle and oil and water repellency up to 20 washes. Polymerization conditions such as time, temperature and dosage of monomer were optimized. Best results were achieved when $25 \%$ of stearic acid was polymerized with $7 \%$ of maleic acid in the presence of catalyst SHP and enhancer TEA. Combination of stearic acid with maleic acid yielded water repellency rating of 4 and oil repellency rating of 1 before any wash and it attained a value of 3 and 1 respectively after 20 washes. Stearic acid with acrylic acid attained water and oil repellency rating of 4 and 1 prior to any wash, however after 20 washes both of these ratings reduced to 2 and zero respectively. The contact angle of modified cotton samples E6 and E8 was increased to $142^{\circ}$ and $136^{\circ}$ respectively due to a combination of stearic acid with maleic acid and acrylic acid respectively. Ester bond formation was confirmed by FTIR analysis. EDX analysis confirmed the absence of fluorine in the newly synthesized recipes. SEM affirms the coating of newly developed polymer onto the cotton fabric. Therefore, newly developed and optimized recipes can give a good alternative to the current toxic fluorine and formaldehyde-based oil and water repellents.

\section{ACKNOWLEDGEMENTS}

Authors are thankful to UET Lahore for funding this research project (No. ORIC/100-ASRB/1990).

\section{REFERENCES}

[1] Qutab, H.G., Mohsin, M., Ramzan, N., Ahmad, S.W., Mitran, E.C., Performance enhancement of diammonium hydrogen phosphate as halogen and formaldehyde free sustainable fire retardant, In: Industria Textila, 2019, 70, 4, 366-373, http://doi.org/10.35530/IT.070.04.1606

[2] Naeem, J., Mazari, A., Akcagun, E., Havelka, A., Kus, Z., Analysis of thermal properties, water vapour resistance and radiant heat transmission through different combinations of firefighter protective clothing, In: Industria Textila, 2018, 69, 6, 458-465, http://doi.org/10.35530/IT.069.06.1463

[3] Zhang, M., Wang, C., Wang, S., Li, J., Fabrication of superhydrophobic cotton textiles for water-oil separation based on the drop-coating route, In: Carbohydrate Polymer, 2013, 97, 1, 59-64

[4] Khanh, V.T.H., Huong, N.T., Influence of crosslinking agent on the effectiveness of flame retardant treatment for cotton fabric, In: Industria Textila, 2019, 70, 5, 413-420, http://doi.org/10.35530/lT.070.05.1610

[5] Faheem, S., Baheti, V., Tunak, M., Wiener, J., Militky, J., Comparative performance of flame retardancy, physiological comfort, and durability of cotton textiles treated with alkaline and acidic casein suspension, In: Journal of Industrial Textile, 2017, 48, 6, 969-991

[6] Stan, M.S., Nica, I.C., Popa, M., Chifiriuc, C.M., Iordache, O., Iuliana Dumitrescu, I., Diamandescu, L., Dinischiotu, A., Reduced graphene oxide/TiO2 nanocomposites coating of cotton fabrics with antibacterial and self-cleaning properties, In: Journal of Industrial Textile, 2019, 49, 3, 277-293

[7] Tonkova, E.V., Staneva, D., Medel, S., Bosch, P., Grozdanov, P., Nikolova, I., Grabchev, I., Antimicrobial, Antibiofilm and Cytotoxicity Activity of a New Acridine Hyperbranched Polymer in Solution and on Cotton Fabric, In: Fibers and Polymers, 2019, 20, 1, 19-24

[8] Akçali, K., Bulut, M.O., A new finishing process of cotton fabric, In: Industria Textila, 2019, 70, 2, 101-110, http://doi.org/10.35530/IT.070.02.1513

[9] Chauhan, P., Kumar, A., Bhushan, B., Self-cleaning, Stain-resistant and Anti-bacterial Superhydrophobic Cotton Fabric Prepared by Simple Immersion Technique, In: Journal of Colloid and Interface Science, 2019, 535, 66-74

[10] Aileni, R.M., Chiriac, L., Subtirica, A., Albici, S., Dinca, L.C., Aspects of the hydrophobic effect sustainability obtained in plasma for cotton fabrics, In: Industria Textila, 2019, 70, 3, 223-228, http://doi.org/10.35530/ IT.070.03.1475 
[11] Kasapgil, E., Anac, I., Erbi, H.Y., Transparent, Fluorine-Free, Heat-Resistant, Water Repellent Coating by Infusing Slippery Silicone Oil on Polysiloxane Nanofilament Layers prepared by Gas Phase Reaction of $n$ Propyltrichlorosilane and Methyltrichlorosilane, In: Colloids and Surfaces A: Physicochemical and Engineering Aspects, 2019, 560, 223-232

[12] Fahmy, H.M., Amr, A., Aly, A.A., Sayed, S.M., Synthesis of castor oil/2, 4-toluene diisocyanate adducts to impart water repellency and antibacterial properties for cotton/polyester fabric, In: Journal of Coatings Technology and Research, 2019, 16, 1, 31-39

[13] Abo-Shosha, M.H., El-Hilw, Z.H., Aly, A.A., Amr, A., Nagdy, Al Said, I.El., Paraffin wax emulsion as water repellent for cotton/polyester blended fabric, In: Journal of Industrial Textiles, 2008, 37, 4, 315-325

[14] Rahman Bhuiyan, M.A., Wang, L., Shaid, A., Shanks, R.A., Ding, J., Polyurethane-aerogel incorporated coating on cotton fabric for chemical protection, In: Progress in Organic Coatings, 2019, 131, 100-110

[15] Ma, Y., Zhu, D., Si, Y., Gang, S., Fabricating durable, fluoride-free, water repellency cotton fabrics with CPDMS, In: Journal of Applied Polymer Science, 2018, 135, 25, 46396-46402

[16] ZDHC, 2012, Available at: https://www.roadmaptozero.com/ [Accessed $6^{\text {th }}$ June 2019]

[17] Liu, X., Yang, G., Lipik, V., Permanent Water Repellent Chemical Modification of Cotton Fabric with Reagents Containing Aromatic Rings, In: Fibers and Polymers, 2019, 20, 1, 51-56

[18] Xue, C.H., Jia, S.T., Chen, H.Z., Wang, M., Superhydrophobic cotton fabrics prepared by sol-gel coating of TiO2 and surface Hydrophobization, In: Science and Technology of Advance Materials, 2008, 9, 3, 35001-35006

[19] Xue, C.H., Jia, S.T., Zhang, J., Tian, L.Q., Superhydrophobic surfaces on cotton textiles by a complex coating of silica nanoparticles and Hydrophobization, In: Thin Solid Films 2009, 517, 16, 4593-4598

[20] Richard, E., Lakshmi, R.V., Aruna, S.T., Basu, B.J., A simple cost-effective and eco-friendly wet chemical process for the fabrication of superhydrophobic cotton fabrics, In: Applied Surface Science, 2013, 277, 302-309

[21] Arfaoui, M.A., Dolez, P.I., Dube, M., David, E., Preparation of a hydrophobic recycled jute-based nonwoven using a titanium dioxide/stearic acid coating, In: The Journal of Textile Institute, 2019, 110, 1, 1455313-1455323

[22] Zhang, Y., Wang, X., Wang, C., Zhai, H., Liu, B., Zhao, X., Fang, D., Wei, Y., Facile preparation of flexible and stable superhydrophobic non-woven fabric for efficient oily wastewater treatment, In: Surface and Coatings Technology, 2019, 357, 526-534

[23] Arfaoui, M.A., Dolez, P.I., Dube, M., David, E., Development and characterization of a hydrophobic treatment for jute fibres based on zinc oxide nanoparticles and a fatty acid, In: Applied Surface Science, 2017, 397, 19-29

[24] Mohsin, M., Farooq, U., Ramzan, N., Rasheed, A., Ahmad, S., Ahsan, M., Softener impact on environment friendly low and zero formaldehyde cross-linker performance for cotton, In: Industria Textila, 2014, 65, 134-139

[25] Mohsin, M., Ramzan, N., Qutab, H.G., Ahmad, S.W., Sarwar, N., Synthesis of halogen and formaldehyde free bio based fire retardant for cotton, In: Industria Textila, 2017, 68, 3, 221-225, http://doi.org/10.35530/IT.068.03.1328

[26] Xiaohong, G., Yang, C.Q., FTIR Spectroscopy Study of the Formation of Cyclic Anhydride Intermediates of Polycarboxylic Acids Catalyzed by Sodium Hypophosphite, In: Textile Research Journal, 2000, 70, 64-70

[27] Qi, H., Zhao, C., Qing, F., Yan, K., Sun, G., Antiwrinkle Finishing of Cotton Fabrics with 5-(Carbonyloxy succinic)benzene-1,2,4-tricarboxylic Acid: Comparison with Other Acids, In: $\square$ Industrial \& Engineering Chemistry Research, 2016, 55, 46, 11850-11856

[28] Mohsin, M., Sarwar, N., Ahmad, S., Rasheed, A., Ahmad, F., Afzal A., Zafar S., Maleic acid crosslinking of C-6 fluorocarbon as oil and water repellent finish on cellulosic fabrics, In: Journal of Cleaner Production, 2016, 112, 4, 3525-3530

[29] Tavera-Quiroz, M.J., Diaz, J.J.F., Pinotti, A., Characterization of Methylcellulose Based Hydrogels by Using Citric Acid as a Crosslinking Agent, In: International Journal of Applied Engineering Research, 2018, 13, 17, 13302-13307

[30] Tang, P., Ji, B., Sun, G., Whiteness improvement of citric acid cross-linked cotton fabrics: $\mathrm{H}_{2} \mathrm{O}_{2}$ bleaching under alkaline condition, In: Carbohydrate Polymers, 2016, 147, 139-145

[31] Huang, Z., Zhou, X., Xing, Z., Wang, B., Improving Application Performance of in situ Polymerization and Crosslinking System of Maleic Acid/Itaconic Acid for Cotton Fabric, In: Fibers and Polymers, 2018, 19, 2, 281-288

[32] Udomkichdecha, W., Kittinaovarat, S., Thanasoonthornroek, U., Potiyaraj, P., Likitbanakorn, P., Acrylic and Maleic Acids in Nonformaldehyde Durable Press Finishing of Cotton Fabric, In: Textile Research Journal 2003, 73, 401-406

[33] Mattonai, M., Pawcenis, D., Seppia, S.D., Lojewska, J., Ribechini, E., Effect of ball-milling on crystallinity index, degree of polymerization and thermal stability of cellulose, In: Bioresource Technology, 2018, 270, 270-277

Authors:

\section{SHARIF RABIA ${ }^{1}$, MOHSIN MUHAMMAD ${ }^{2}$, RAMZAN NAVEED ${ }^{3}$,} AHMAD SYED WAQAS ${ }^{1}$, HAJI GHULAM QUTAB ${ }^{1}$

${ }^{1}$ Department of Chemical Engineering, UET Lahore, Faisalabad Campus, Pakistan

${ }^{2}$ Department of Textile Engineering, UET Lahore, Faisalabad Campus, Pakistan

${ }^{3}$ Department of Chemical Engineering, UET Lahore, Main Campus, Pakistan

\section{Corresponding author:}

email: mohsinmalikntu@yahoo.com 


\title{
Characterization of fabrics coated with doped $\mathrm{TiO}_{2}$-graphene
}

DOI: 10.35530/IT.071.02.1625

IULIANA DUMITRESCU

OVIDIU-GEORGE IORDACHE

IRINA-MARIANA SĂNDULACHE

ELENA-CORNELIA MITRAN

LUCIA-OANA SECĂREANU

ELENA PERDUM

ARCADII SOBETKII

\author{
ABSTRACT - REZUMAT
}

\section{Characterization of fabrics coated with doped $\mathrm{TiO}_{2}$-graphene}

This study presents the results of laboratory experiments to prepare cotton woven fabrics with photoactive properties. The fabric was treated with $\mathrm{TiO}_{2}-\mathrm{Fe}(1 \%)-N+2 \%$ graphene by exhaustion followed by a fluorocarbon polymer treatment. The fabric was analyzed by Scanning Electron Microscope coupled with Energy Dispersive Spectroscopy (SEM/EDAX), Differential scanning calorimetry (DSC), Contact Angle measurement, physical properties (weight, thickness, breaking strength, elongation, air/water permeability, electrical resistance). The photocatalytic activity was determined initially and after 5 washings by measuring the trichromatic coordinates of the treated fabrics stained with methylene blue and exposed to UV and visible light on a Hunterlab UV-Vis spectrophotometer.

The results demonstrate a uniform deposition of doped $\mathrm{TiO}_{2}$-graphene particles on material surface. The thermal stability of the coated cotton fabric is practically unmodified in comparison with blank cotton fabric.

The decrease of the surface resistivity demonstrates the deposition of graphene layer, known for its good electrical conductivity. The wetting capacity of initial hydrophilic cotton fabric is dramatically modified, the fabric becoming hydrophobic after treatment. The photocatalytic efficiency is higher under visible light than under UV-radiation due to the $\mathrm{TiO}_{2}$ doping and decoration with graphene, which extend the light absorption from UV to visible range. The good photocatalytic activity under visible light is maintained after 5 washing cycles.

Keywords: doped $\mathrm{TiO}_{2}$-graphene, photocatalytic textiles, cotton fabrics, physical properties

\section{Caracterizarea ţesăturilor acoperite $\mathrm{Cu} \mathrm{TiO}_{2}$-grafen dopat}

Studiul prezintă rezultatele experimentelor de laborator pentru obținerea ţesăturilor din bumbac cu proprietăţi fotocatalitice. Tesătura a fost tratată $\mathrm{cu} \mathrm{TiO}_{2}-\mathrm{Fe}(1 \%)-N+2 \%$ grafen, prin exhaustare, urmată de un tratament cu polimer de fluorocarbon. Tesătura a fost analizată prin Microscopie Electronică de Baleiaj cuplată cu Spectroscopie de Raze X cu dispersie de energie (SEM/EDAX), Calorimetrie de Scanare Diferenţială (DSC), măsurarea unghiului de contact și determinarea valorilor caracteristicilor fizico-mecanice (masă, grosime, rezistenţă la rupere, alungire la rupere, permeabilitate la aerlapă, rezistenţă electrică). Activitatea fotocatalitică a fost determinată iniţial şi după 5 spălări prin măsurarea coordonatelor tricromatice ale ţesăturilor tratate, pătate cu albastru de metilen şi expuse la UV şi lumina vizibilă, pe un spectrofotometru UV-Vis Hunterlab.

Rezultatele demonstrează o depunere uniformă a particulelor de $\mathrm{TiO}_{2}$-grafen dopat pe suprafaţa ţesăturii. Stabilitatea termică a ţesăturii din bumbac acoperite este practic nemodificată, comparativ cu ţesătura din bumbac netratată.

Scăderea rezistenţei de suprafaţă demonstrează depunerea unui strat de grafen, cunoscut pentru conductibilitatea electrică bună. Capacitatea de umectare iniţială a ţesăturii din bumbac este dramatic modificată, aceasta devenind hidrofobă după tratare. Eficienţa fotocatalitică este mai mare în lumina vizibilă, decât în radiaţie UV, datorită dopării TiO 2 şi acoperirii cu grafen, care extind absorbţia luminii din domeniul UV în domeniul vizibil. Activitatea fotocatalitică sub lumina vizibilă se menţine şi după 5 cicluri de spălare.

Cuvinte-cheie: $\mathrm{TiO}_{2}$-grafen dopat, textile fotocatalitice, ţesături din bumbac, proprietăţi fizice

\section{INTRODUCTION}

Titanium dioxide was intensively investigated to prepare textiles with new functionalities such as selfcleaning, hydrophilicity, antibacterial, UV-protection, etc. [1-3]. As it is well known, the major drawback of $\mathrm{TiO}_{2}$ is the efficiency only under UV light $(\lambda<387 \mathrm{~nm})$ due its large band gap of $3.2 \mathrm{eV}$ [4]. To extend the absorption under visible light, $\mathrm{TiO}_{2}$ was doped with metals, non-metals and recently with carbon nanotubes, graphene oxide, graphene [5].
The composition $\mathrm{TiO}_{2}$-graphene has an improved photocatalytic efficiency due to the fast transfer electrons from the conduction band of $\mathrm{TiO}_{2}$ to graphene sheets, suppressing the recombination of the formed electron-hole pair formed and, therefore increasing the lifetime of the pair and generation of a higher number of active species involved in photo-degradation. More than that, graphene having a huge surface area, allow a better contact with the contaminants, which are absorbed and decomposed by the generated radicals [6]. 
The studies show antimicrobial, photocatalytic selfcleaning and UV blocking activity of the cotton fabrics treated by dip-drying technique with graphene oxide/ $\mathrm{TiO}_{2}$ nanocomposites [7-8]. Polyester fabric coated with multiple layers of reduced graphene oxide and $\mathrm{TiO}_{2}$ demonstrates light absorption, conductivity, electro-activity and photocatalytic properties [6].

Wool fabric coated with graphene/ $\mathrm{TiO}_{2}$ nanocomposite, besides the improved antibacterial activity and electrical conductivity, has a good photo-catalytic self-cleaning property under sunlight [9].

While almost all the researches are directed to analyses the functional properties, few of them investigate the physical modifications of the treated fabrics. The present study is focused on the physical properties and photocatalytic activity of the cotton woven material coated with doped $\mathrm{TiO}_{2}$-graphene composite.

\section{EXPERIMENTAL}

\section{Materials}

The following materials were used for the experiments: $100 \%$ cotton woven fabric which characteristics are shown in the table $1 ; \mathrm{TiO}_{2}-\mathrm{Fe}(1 \%)-\mathrm{N}+2 \%$ graphene (average diameter: $17.8 \mathrm{~nm}$ ) hydrothermal synthetized by National Institute of Materials Physics, Romania; sodium dodecylhydogensulphate (DHS); poly(ethylenebenzensufonic) acid (PBS); Nuva® 4200 liq.(perfluorocarbon polymer).

\section{Methods}

The fabric was introduced into $0.49 \mathrm{~g} / \mathrm{L}$ doped $\mathrm{TiO}_{2}-$ graphene dispersion prepared by sonication $0.5 \mathrm{~g}$ $\mathrm{TiO}_{2}-\mathrm{Fe}(1 \%)-\mathrm{N}+2 \% \mathrm{GO}$ powder in $1000 \mathrm{~mL}$ solution containing $0.19 \mathrm{~g}$ DHS, $15 \mathrm{~mL}$ ethanol and $0.6 \mathrm{~mL}$ PBS for 3 hours at $30^{\circ} \mathrm{C}$. The fabric was immersed in the above prepared dispersion, maintained at $40^{\circ} \mathrm{C}$ for 30 minutes and then, dried at $100^{\circ} \mathrm{C}$ for 2 minutes. The fabric so treated was named
S6G. The dried fabric is immersed in $20 \mathrm{~g} / \mathrm{L}$ Nuva ${ }^{\circledR}$ 4200 liq., at $\mathrm{pH} 5$, dried at $110^{\circ} \mathrm{C}$, and thermofixed at $170^{\circ} \mathrm{C}$ for 40 seconds. The fabric was abbreviated S6.

\section{Characterization}

The fabric morphology and chemical composition of deposited layers were investigated by scanning electron microscopy coupled with Energy Dispersive Spectroscopy (SEM/EDAX, Quanta 200, FEI, Netherlands). The wetting capacity was determined by measuring the contact angles with a $5 \mu$ distilled water droplet on a VCA Optima (AST Products Inc., USA) instrument. The results are the average of 5-10 measurements in different points on the samples surface. The thermal properties of the coated fabric were measured on DSC (Pyris Diamond, Perkin Elmer, USA) instrument, with a heating rate of $10^{\circ} \mathrm{C} / \mathrm{min}$. and using $10 \mathrm{~mL} / \mathrm{min}$. air as a purging gas. The electrical resistivity was measured with PRS 801 digital multi-meter (Prostat Corporation, USA), according standard SR EN 1149-1: 2006 , at $19.5^{\circ} \mathrm{C}$ and $35.1 \%$ relative humidity. The physical properties of the fabrics (weight, thickness, breaking strength, elongation, air/water permeability) were analyzed according to specific ISO standards. The photocatalytic efficiency of the untreated and treated materials was evaluated by measuring the trichromatic coordinates of materials stained with methylene blue and the exposed at UV and visible light on Hunterlab spectrophotometer, with CIELAB 1976 color space and D65-light source. The nanoparticles adherence on the fabric surface and efficiency to washing was investigated by subjecting the fabric to 5 washing cycles, staining with methylene blue, exposing to visible light and evaluation of the color changes.

\begin{tabular}{|c|c|c|c|c|}
\hline \multicolumn{5}{|c|}{ PHYSICAL-MECHANICAL PROPERTIES OF THE FABRICS } \\
\hline \multicolumn{2}{|l|}{ Analysis } & Blank & S6 & Standard \\
\hline \multicolumn{2}{|l|}{ Weight $\left(\mathrm{g} / \mathrm{m}^{2}\right)$} & 253 & 249 & SR EN 12127:2003 \\
\hline \multicolumn{2}{|l|}{ Thickness (mm) } & 0.568 & 0.635 & SR EN ISO 5084:2001 \\
\hline \multicolumn{2}{|c|}{ Water vapor permeability (\%) } & 31.6 & 34.3 & STAS 9005:1979 \\
\hline \multicolumn{2}{|c|}{ Air permeability at $100 \mathrm{~Pa}\left(\mathrm{Lm}^{-2} \mathrm{~s}^{-1}\right)$} & 75.66 & 75.92 & SR EN ISO 9237:1999 \\
\hline \multirow{2}{*}{$\begin{array}{l}\text { Fabric density (number of } \\
\text { yarns } / 10 \mathrm{~cm} \text { ) }\end{array}$} & Warp & 414 & 420 & \multirow{2}{*}{ SR EN 1049-2:2000-Method A,B } \\
\hline & Weft & 214 & 214 & \\
\hline \multirow{2}{*}{ Breaking force $(\mathrm{N})$} & Warp & 710 & 1051 & \multirow{4}{*}{ SR EN ISO 13934-1/2013 } \\
\hline & Weft & 470 & 511 & \\
\hline \multirow{2}{*}{ Breaking elongation (\%) } & Warp & 15.10 & 20.2 & \\
\hline & Weft & 15.10 & 15.26 & \\
\hline \multicolumn{2}{|c|}{ Surface resistivity (× $\left.10^{13} \Omega \mathrm{sq}\right)$} & 18.9 & 6.96 & \multirow{2}{*}{ SR EN 1149-1: 2006} \\
\hline \multicolumn{2}{|c|}{ Volume resistivity $\left(\times 10^{14} \Omega \mathrm{cm}\right)$} & 11.5 & 18.8 & \\
\hline \multicolumn{2}{|c|}{ Contact angle, left/right (degrees) } & 0 & 146.16 & Sessile drop method \\
\hline
\end{tabular}






a



b

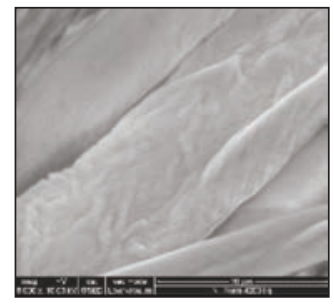

c

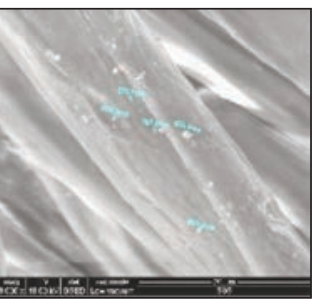

d

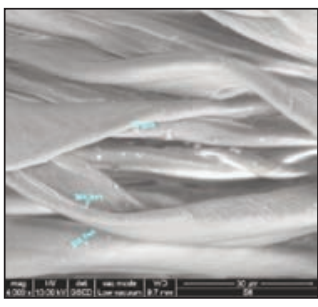

e

Fig. 1. SEM images of untreated and treated fabrics: $a$ - untreated; $b$ - treated with DHS \& PBS; $c-$ treated with NUVA 4200 liq.; $d$ - S6G; $e$ - S6

\section{RESULTS AND DISSCUSION}

\section{Surface morphology investigation of coated} fabric by SEM

The SEM images of fabric untreated and treated with $\mathrm{TiO}_{2}-\mathrm{Fe}(1 \%)-\mathrm{N}+2 \%$ graphene are shown in figure 1.

The SEM images of the materials untreated (figure 1, a) and treated with DHS \& PBS (figure 1,b) show a clean, smooth surface. The fluorocarbon polymers, NUVA4200 liq., form a thick layer on the fibers surface. On the surface of the S6G fibers (figure 1,d) the polymer layer (PBS) is observed on which random particles of $221.6 \mathrm{~nm}, 265.2 \mathrm{~nm}, 257.6 \mathrm{~nm}, 495.4 \mathrm{~nm}$ are dispersed. It is possible that the sheets present on certain fibers are graphene because the particles attached to doped $\mathrm{TiO}_{2}$ are seen on their edges. After treatment with fluorocarbon polymer, on the fibers surface (figure 1,e) a small number of particles (72.9 $\mathrm{nm}, 262.7 \mathrm{~nm}, 364.3 \mathrm{~nm}$ ) are observed due to their inclusion in the thick polymer layer.
EDAX quantification of the elements on the treated cotton fabric

The spectra and chemical composition of nanoparticles present on the fabric coated with $\mathrm{TiO}_{2}-\mathrm{Fe}(1 \%)$ $-\mathrm{N}+2 \%$ graphene are shown in the figure 2 and table 2 .

The results demonstrate the presence of $\mathrm{Ti}$ as major element on the coated fabrics, in larger amount on the sample S6G than on sample S6. After the treatment with NUVA 4200, almost $62 \% \mathrm{Ti}$ is removed due to the low adherence of particles on the fabric surface.

\section{DSC analysis of the coated fabrics}

The thermal behavior of the coated samples is shown in the figure 3 and table 3 . The $\mathrm{TiO}_{2}$-graphene composite powder shows an exothermic peak at $256^{\circ} \mathrm{C}$, associated with thermal decomposition and oxidation of organic matter resulting from the doped $\mathrm{TiO}_{2}$ synthesis process. Iron doping causes the exothermic point to drop, which is higher as the amount of iron is higher. Thus, studies [10] have shown that $\mathrm{TiO}_{2}$ doped with $1 \%$ Fe shows an exothermic peak at

\begin{tabular}{|c|c|c|c|c|c|c|c|c|c|c|}
\hline \multicolumn{8}{|c|}{ QUANTIFICATION OF THE ELEMENTS ON THE FABRICS SURFACE BY EDAX } \\
\hline Sample & \multicolumn{2}{|c|}{ Untreated fabric } & \multicolumn{2}{|c|}{$\begin{array}{c}\text { Treated with DHS } \\
\text { and PBS }\end{array}$} & $\begin{array}{c}\text { Treated with } \\
\text { N Nuva 4200liq. }\end{array}$ & \multicolumn{2}{|c|}{ S6 } & \multicolumn{4}{c|}{ S6G } \\
\hline Element & Wt (\%) & At (\%) & Wt (\%) & At (\%) & Wt (\%) & At (\%) & Wt (\%) & At (\%) & Wt (\%) & At (\%) \\
\hline C K & 45.83 & 52.99 & 46.75 & 53.91 & 43.71 & 51.15 & 40.02 & 47.37 & 42.55 & 50.53 \\
\hline O K & 54.17 & 47.01 & 53.25 & 46.09 & 51.96 & 45.65 & 58.86 & 52.30 & 54.50 & 48.59 \\
\hline F K & - & - & - & - & 4.33 & 3.20 & - & - & - & - \\
\hline TiK & - & - & - & - & - & - & 1.12 & 0.33 & 2.95 & 0.88 \\
\hline Total & 100 & 100 & 100 & 100 & 100 & 100 & 100 & 100 & 100 & 100 \\
\hline
\end{tabular}

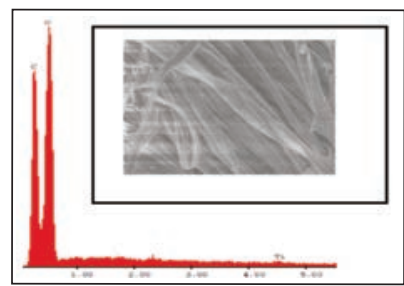

a

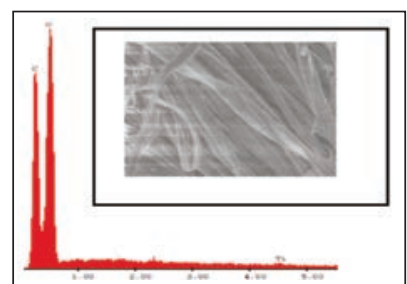

b

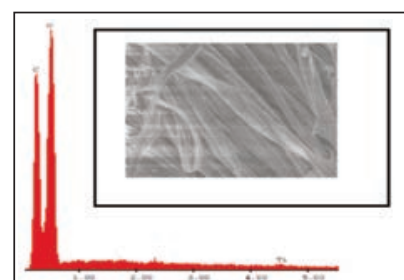

c

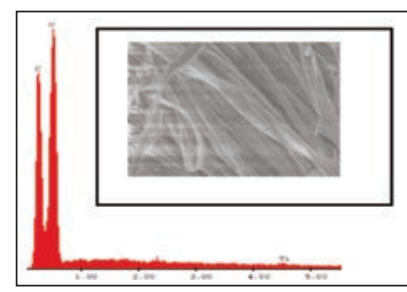

d

Fig. 2. EDAX spectra of the fabrics surface: $a$ - untreated; $b$ - treated with DHS and PBS; $c$ - treated with NUVA 4200 liq.; $d$ - S6G 


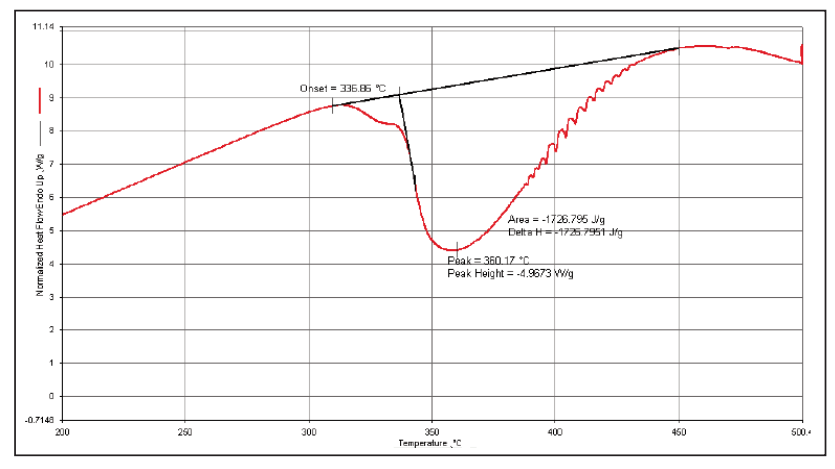

a

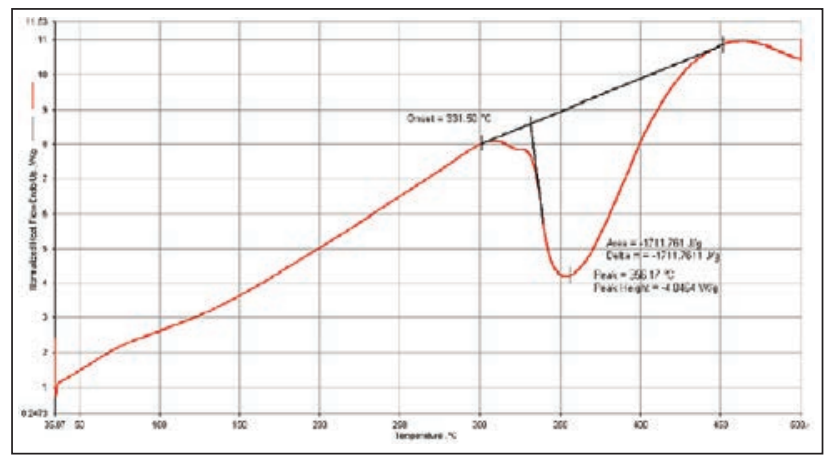

C

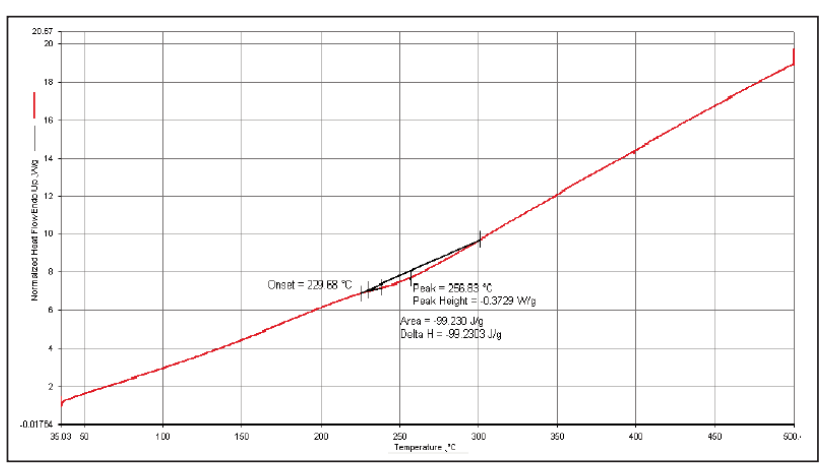

$\boldsymbol{b}$

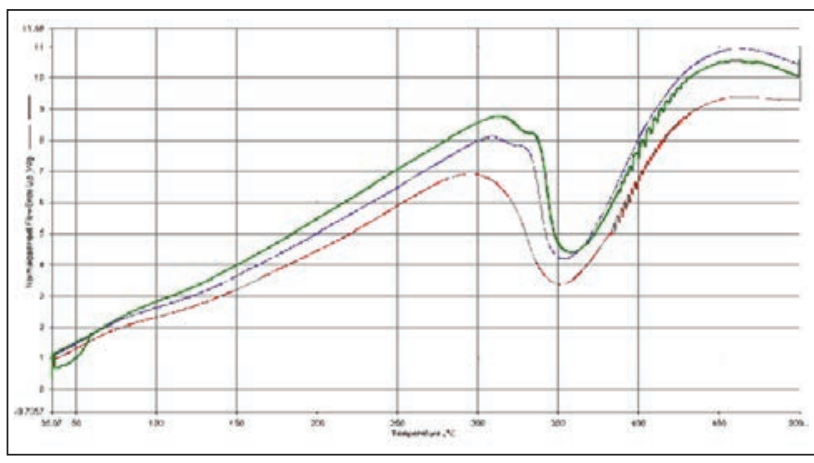

d

Fig. 3. DSC curves of fabrics: $a-$ Blank, untreated cotton fabric; $b-\mathrm{TiO}_{2}-\mathrm{Fe}(1 \%)-\mathrm{N}+2 \% \mathrm{GO}$ powder; $c-\mathrm{S} 6 \mathrm{G}$; $d$ - superimposed DSC Thermograms: blue - S6G, red - S6, green - blank

\begin{tabular}{|c|c|c|c|c|}
\hline \multicolumn{5}{|c|}{ DSC ANALYSIS DATA OF FABRICS AND DOPED TIO ${ }_{2}$-GRAPHENE POWDER } \\
\hline Sample & Blank & TiO $_{2}$-Fe (1\%)-N +2\% G powder & S6 & S6G \\
\hline Weight $(\mathrm{mg})$ & 7.3 & 5 & 7.2 & 7.1 \\
\hline Temp. max. $\left({ }^{\circ} \mathrm{C}\right)$ & 360.17 & 256.83 & 354.51 & 356.17 \\
\hline$\Delta \mathrm{H}(\mathrm{J} / \mathrm{g})$ & -1726.795 & -99.2303 & -1833.5558 & -1711.761 \\
\hline Onset t $\left({ }^{\circ} \mathrm{C}\right)$ & 336.86 & 229.68 & 315.36 & 331.50 \\
\hline Final $\left({ }^{\circ} \mathrm{C}\right)$ & 450 & 300 & 450 & 452 \\
\hline
\end{tabular}

$223^{\circ} \mathrm{C}$. If the dopant is nitrogen, the exothermic point is shifted to higher values, respectively $274^{\circ} \mathrm{C}$ [11] attributed to the evaporation of solvent, the $\mathrm{N}$ precursor and its derivatives. Graphene, which, theoretically has two peaks between $200-300^{\circ} \mathrm{C}$ (decomposition of oxygen-containing groups) and $550-650^{\circ} \mathrm{C}$ (oxidation of carbon residues), also contributes to the temperature change. The untreated cotton fabric has an exothermic peak $\left(360.17^{\circ} \mathrm{C}\right)$ attributed to cellulose decomposition [12]. After treatment with doped $\mathrm{TiO}_{2}-$ graphene, the temperature drops by $4-6^{\circ} \mathrm{C}$ demonstrating that treatment does not essentially influence the thermal behavior of cotton.

\section{The physical-mechanical characteristics}

The physical-mechanical properties of the initial and treated fabrics are shown in the table 1. Except the weight, all the physical characteristics analyzed show slightly modifications. The results demonstrate an increase of thickness (11.79\%), fabric density on warp $(1.45 \%)$, breaking force $(48 \%$ on warp and
$8.72 \%$ on weft) and elongation at breaking (33.77\%). The water vapor and air permeability are slightly changed, increasing by $8.5 \%$ and respectively $0.35 \%$. Instead, the surface and volume resistivity are decreased, mainly due to graphene.

The initial cotton fabric is highly hydrophilic, the water being absorbed instantaneously. Also, the fabric treated with doped $\mathrm{TiO}_{2}$-graphene is hydrophilic, probably due to the high content of $\mathrm{TiO}_{2}$ deposited on the material surface. After coating with fluorocarbon polymer, the material becomes hydrophobic, due to the polymer, specially used to provide oil and water repellency to the textile materials.

The evaluation of photocatalytic effect

The aspect and the color changes of the materials stained with methylene blue under visible and UV light are shown in the tables 4-7.

As it can be seen, methylene blue suffers a very slight photo-degradation on the untreated material after 8 hours of exposure to UV light. Instead, the 
ASPECT OF THE FABRICS STAINED WITH METHYLENE BLUE AND EXPOSED AT UV LIGHT (365NM)

\begin{tabular}{|c|c|}
\hline Initial & 8 hours \\
\hline \multicolumn{2}{|c|}{ Blank } \\
\hline \multicolumn{2}{|c|}{ S6G } \\
\hline \multicolumn{2}{|c|}{ S6 } \\
\hline
\end{tabular}

THE ASPECT OF THE FABRICS, STAINED WITH METHYLENE BLUE, EXPOSED AT VISIBLE LIGHT



Table 6

TRICHROMATIC COORDINATES OF THE FABRICS STAINED WITH METHYLENE BLUE, EXPOSED 8 HOURS AT UV LIGHT

\begin{tabular}{|c|c|c|c|c|c|c|c|c|}
\hline Sample & $\mathbf{L}^{*}$ & $\mathbf{a}^{*}$ & $\mathbf{b}^{*}$ & $\mathbf{d L}^{*}$ & $\mathbf{d a}^{*}$ & $\mathbf{d b}^{*}$ & $\mathbf{d E}^{*}$ & Note \\
\hline Blank unexposed & 87.52 & -13.39 & -7.69 & & & & & \\
\hline Blank exposed & 87.92 & -13.10 & -7.46 & 0.40 & 0.29 & 0.23 & 0.55 & 4.5 \\
\hline S6 unexposed & 83.01 & -17.54 & -10.46 & & & & & \\
\hline S6 exposed & 84.69 & -15.28 & -9.00 & 1.68 & 2.25 & 1.46 & 3.17 & 3.50 \\
\hline S6G unexposed & 84.70 & -10.77 & -5.02 & & & & & \\
\hline S6G exposed & 85.94 & -8.73 & -3.26 & 1.24 & 2.04 & 1.76 & 2.96 & 3.50 \\
\hline
\end{tabular}

Table 7

TRICHROMATIC COORDINATES OF THE FABRICS STAINED WITH METHYLENE BLUE, EXPOSED 8 HOURS AT VISIBLE LIGHT

\begin{tabular}{|c|c|c|c|c|c|c|c|c|}
\hline Sample & $\mathbf{L}^{*}$ & $\mathbf{a}^{*}$ & $\mathbf{b}^{*}$ & $\mathbf{d L}^{*}$ & $\mathbf{d a}^{*}$ & $\mathbf{d b}^{*}$ & $\mathbf{d E}^{*}$ & Note \\
\hline Blank unexposed & 87.01 & -13.97 & -8.63 & & & & & \\
\hline Blank exposed & 89.91 & -5.96 & -4.09 & 2.90 & 8.01 & 4.54 & 9.66 & 1.5 \\
\hline S6 unexposed & 83.62 & -16.08 & -9.89 & & & & & \\
\hline S6 exposed & 86.77 & -5.82 & -4.72 & 3.15 & 10.27 & 5.18 & 11.92 & 1.5 \\
\hline S6G unexposed & 84.57 & -10.68 & -4.88 & & & & & \\
\hline S6G exposed & 84.85 & -3.20 & -0.94 & 0.29 & 7.48 & 3.93 & 8.45 & 1.50 \\
\hline
\end{tabular}

notes on gray scale demonstrate a more intense photo-degradation of methylene blue existing on the treated fabrics (S6 and S6G).

According to the value of light and color differences $\left(\mathrm{dE}^{*}\right)$, the fabric coated with $\mathrm{TiO}_{2}$-graphene and fluorocarbon polymer (S6G) is more strongly photodegraded than the material treated with only $\mathrm{TiO}_{2}$ graphene.

Under the visible light, the most intensive degradation is shown by the fabric S6 due to the deposited photo-catalyst on the material surface. According to $\mathrm{dL}^{*}$ and $\mathrm{dE}^{*}$ values, the sample S6G is less degraded than the blank. The results could be influenced by the black color of graphene and the lower amount of $\mathrm{TiO}_{2}$ present on the material surface.

\section{Evaluation of the photocatalytic effect after} washing

The durability of the photocatalytic efficiency was tested by subjecting the materials to 5 washing cycles under the following conditions. Trichromatic coordinates of the washed fabrics exposed to UV and visible are shown in tables 8-10.

After 5 washings and exposure to UV light, the color fading of methylene blue on both fabrics is very low, as it could be seen from the notes on gray scale, which is similar for treated and untreated fabric. The 


\begin{tabular}{|c|c|c|c|c|}
\hline \multicolumn{3}{|c|}{ ASPECT OF THE FABRICS AFTER 5 WASHINGS, EXPOSED TO UV AND VISIBLE LIGHT } \\
\hline \multirow{2}{*}{$\begin{array}{c}\text { Exposure } \\
\text { time }\end{array}$} & \multicolumn{2}{|c|}{ Exposed 8 hours to UV light } & \multicolumn{2}{|c|}{ Exposed 4 hours to visible light } \\
\cline { 2 - 5 } & Blank & S6 & Blank & \\
\hline Initial & & & & \\
\hline \multirow{2}{*}{8 hours } & & & & \\
\hline
\end{tabular}

\begin{tabular}{|c|c|c|c|c|c|c|c|c|}
\hline \multicolumn{8}{|c|}{ TRICHROMATIC COORDINATES OF THE FABRICS AFTER 5 WASHINGS, EXPOSED 8 HOURS TO UV LIGHT } \\
\hline Sample & $\mathbf{L}^{*}$ & $\mathbf{a}^{*}$ & $\mathbf{b}^{*}$ & $\mathbf{d L ^ { * }}$ & $\mathbf{d a}^{*}$ & $\mathbf{d b}^{*}$ & $\mathbf{d E}^{*}$ & Note $^{*}$ \\
\hline Blank unexposed & 86.57 & -14.90 & -10.72 & & & & & \\
\hline Blank exposed & 86.73 & -12.85 & -9.95 & 0.15 & 2.05 & 0.76 & 2.19 & 4.00 \\
\hline S6 unexposed & 81.50 & -17.78 & -14.79 & & & & & \\
\hline S6 exposed & 82.60 & -17.57 & -13.03 & 1.10 & 0.21 & 1.76 & 2.08 & 4.00 \\
\hline
\end{tabular}

Table 10

\begin{tabular}{|c|c|c|c|c|c|c|c|c|}
\hline \multicolumn{7}{|c|}{ TRICHROMATIC COORDINATES OF THE FABRICS AFTER 5 WASHINGS, EXPOSED 4 HOURS TO VISIBLE LIGHT } \\
\hline Sample & $\mathbf{L}^{*}$ & $\mathbf{a}^{*}$ & $\mathbf{b}^{*}$ & $\mathbf{d L}$ & $\mathbf{d a}$ & $\mathbf{d} \mathbf{d b}^{*}$ & $\mathbf{d E}^{*}$ & $\mathbf{N o t e}^{*}$ \\
\hline Blank unexposed & 84.09 & -15.13 & -12.10 & & & & & \\
\hline Blank exposed & 88.61 & -5.30 & -5.45 & 4.52 & 9.84 & 6.65 & 12.71 & 1 \\
\hline S6 unexposed & 81.22 & -17.53 & -14.41 & & & & & \\
\hline S6 exposed & 83.78 & -7.92 & -9.04 & 2.55 & 9.61 & 5.37 & 11.30 & 1.5 \\
\hline
\end{tabular}

higher $\mathrm{dL}^{*}$ value of sample $\mathrm{S} 6$ indicates a higher degradation of dye on the treated material.

After 5 washings, the photocatalytic efficiency is lost, probably due to the removal of $\mathrm{TiO}_{2}$-graphene.

\section{CONCLUSIONS}

The SEM/EDAX analyses confirm the deposition of $\mathrm{TiO}_{2}$-graphene on fabrics. The treated fabrics show a more intensive photo-degradation under visible light than under UV light. The photocatalytic effects were preserved after five washing cycles, demonstrating the capacity of polymer to fix the particles on the fabric surface. The genuine characteristics of the textile materials are not significantly modified by the chosen treatment method.

\section{ACKNOWLEDGMENTS}

This study was supported by the Executive Unit for Financing Higher Education, Research, Development and Innovation (UEFISCDI) through the project No. 87/2014 CLEANTEX from in the frame of PN II Program.

\section{REFERENCES}

[1] Sobczyk-Guzenda, A. et al., Morphology, photocleaning and water wetting properties of cotton fabrics, modified with titanium dioxide coatings synthesized with plasma enhanced chemical vapor deposition technique, In: Surface and Coatings Technology, 2013, 51-57

[2] Karimi, L., et al., Optimizing the photocatalytic properties and the synergistic effects of graphene and nano titanium dioxide immobilized on cotton fabric, In: Applied Surface Science, 2015, 665-673

[3] Wu, H., Wu, L., Kang, S., Yin, J., Application of nano-TiO ${ }_{2}$ in sizing of kapok blended yarn, In: Industria Textila, 2019, 70, 2, 192-196, http://doi.org/10.35530/IT.070.02.1578

[4] Dette, C., Pérez-Osorio, M.A., Kley, C.S., Punke, P., Patrick, C.E., Jacobson, P., Giustino, F., Jung, S.J., Kern, K., $\mathrm{TiO}_{2}$ Anatase with a Bandgap in the Visible Region, In: Nano Lett., 2014, 14, 11, 6533-6538

[5] Bhanvase, B.A., Shende, T.P., Sonawane, S.H., A review on graphene- $\mathrm{TiO}_{2}$ and doped graphene-TiO nanocomposite photocatalyst for water and wastewater treatment, In: Journal of Environmental Technology Reviews, 2017, 6, 1

[6] Rahman, Md.M., Durable Multifunctional Properties on Polyester Fabric by Applying Nanocoating, In: Nanoscience and Nanotechnology, 2017, 7, 1, 14-20 
[7] Karimi, L., Yazdanshenas, M.E., Khajavi, R., Rashidi, A., Mirjalili, M., Functional finishing of cotton fabrics using graphene oxide nanosheets decorated with titanium dioxide nanoparticles, In: The Journal of The Textile Institute, 2015, Available at: https://www.researchgate.net/publication/282428151_Functional_finishing_of_cotton_fabrics_ using_graphene_oxide_nanosheets_decorated_with_titanium_dioxide_nanoparticles [Accessed September 2017]

[8] Karimi, L. , Yazdanshenas, M.E., Khajavi, R., Rashidi, A., Mirjalili, M., Using graphene/TiO ${ }_{2}$ nanocomposite as a new route for preparation of electroconductive, self-cleaning, antibacterial and antifungal cotton fabric without toxicity, In: Cellulose, 2015, 21, 5, 3813-3827

[9] Shirgholami, M.A., Karimi, L., Mirjalili, M., Multifunctional modification of wool fabric using graphene/TiO 2 nanocomposite, In: Fibers and Polymers, 2016, 17, 2, 220-228

[10] Rodrigues, E.C., Soares, L.A., Modenes Jr, M.A., Sene, J.J., Bannach, G., Carvalho, C.T., Ionashiro, M., Synthesis and characterization of $\mathrm{Fe}(\mathrm{III})$-doped ceramic membranes of titanium dioxide and its application in photoelectrocatalysis of a textile dye, In: Eclectica Química, 2011, 36, 1

[11] Ramalingam, R.J., Arunachalam, P., Radhika, T., Anju, K.R., Nimitha, K.C., Al-Lohedan, H.A., Surface and Electrochemical Characterization of N-Fe-dopedTiO2 Nanoparticle Prepared by Hydrothermal and Facile ElectroDeposition Method for Visible Light Driven Pollutant, In: Int. J. Electrochem. Sci., 2017, 12, 797-811

[12] Dahiya, J.B., Rana, S., Thermal behaviour and spectral studies on cotton cellulose modified with phosphorous, sulphur and metals, In: Indian Journal of Chemistry, 2005, 44A, 2024-2029

Authors:

IULIANA DUMITRESCU - In memoriam OVIDIU-GEORGE IORDACHE ${ }^{1}$, ELENA-CORNELIA MITRAN ${ }^{1}$, ELENA PERDUM ${ }^{1}$, IRINA-MARIANA SĂNDULACHE ${ }^{1}$, LUCIA-OANA SECĂREANU ${ }^{1}$, ARCADII SOBETKII

${ }^{1}$ INCDTP - National Research and Development Institute for Textiles and Leather, 16 Lucretiu Patrascanu Street, 030508, Bucharest, Romania e-mail: office@incdtp.ro

${ }^{2}$ National Research-Development Institute for Non-Ferrous and Rare Metals - IMNR, 102 Biruintei Blvd., 077145, Pantelimon, Ilfov, Romania

Corresponding author:

OVIDIU-GEORGE IORDACHE

e-mail: ovidiu.iordache@incdtp.ro 


\section{Researches on the use of textile materials for protection against soil erosion}

DOI: 10.35530/IT.071.02.1627

BOGDAN-IULIAN DOROFTEI

OVIDIU-GEORGE IORDACHE

MIRCEA DEGERATU

IOANA CORINA MOGA

GEORGETA BANDOC

\section{ABSTRACT - REZUMAT}

\section{Researches on the use of textile materials for protection against soil erosion}

Erosion of sandy soil due to wind action is a global ecological problem with major implications both in the field of agriculture and in the socio-economic sphere. Erosion and sand transport have a negative effect both in the "active area" in which it occurs and outside it, not being a strictly defined phenomenon. The present paper deals with the problems due to the erosion of soils by wind, and the way of diminishing this phenomenon by using some protective textile screens placed transversely to the wind direction. The aim of the paper is to provide numerical contributions on wind interaction with permeable soil protection obstacles. For concrete data, a number of numerical simulations of the air flow in the atmospheric boundary layer area was carried out, in the presence of a wind barrier having different degrees of permeability, depending on the textile used, for the determination of the speed upstream and downstream of the obstacle. The program used for the numerical simulation is ANSYS Fluent ${ }^{\mathrm{TM}}$, a computational fluid dynamics software that uses a variety of equations for the modelling of fluid flow. The results obtained will be used as a basis for further research, based on scaled textile barriers models for physical experiments in the aerodynamic tunnel.

Keywords: environmental protection, wind soil erosion, protection textile screens, numerical simulations, turbulent $k-\varepsilon$ model

\section{Cercetări privind folosirea materialelor textile pentru protecţia împotriva eroziunii solului}

Eroziunea solului nisipos, din cauza acţiunii vântului, reprezintă o problemă ecologică globală cu implicaţii majore atât în domeniul agriculturii, cât şi în sfera socio-economică. Eroziunea şi transportul nisipului au un efect negativ atât în „zona activă”, în care are loc, cât şi în afara acesteia, nefiind un fenomen strict definit. Lucrarea de faţă tratează problemele cauzate de eroziunea solurilor de către vânturi şi modul de diminuare al acestui fenomen, prin utilizarea de ecrane textile de protecţie plasate transversal pe direcţia vântului. Scopul lucrării este de a oferi contribuţii numerice asupra interacţiunii vântului cu obstacolele permeabile de protecţie ale solului. Pentru date concrete, a fost efectuat un număr de simulări numerice ale fluxului de aer în zona stratului de delimitare atmosferică, în prezenţa unei bariere de vânt cu diferite grade de permeabilitate, în funcţie de materialul textil folosit, pentru determinarea vitezei în amonte şi în aval de obstacol. Programul folosit pentru simulare numerică este ANSYS Fluent ${ }^{T M}$, un software de dinamică computaţională a fluidelor, care utilizează o varietate de ecuaţii pentru modelarea fluxului de fluide. Rezultatele obţinute vor fi utilizate ca bază pentru cercetări ulterioare, folosind modele scalate de bariere textile, pentru experimente fizice în tunelul aerodinamic.

Cuvinte-cheie: protecţia mediului, eroziune sol cauzată de vânt, ecrane textile de protecţie, simulări numerice, model $k-\varepsilon$ turbulent

\section{INTRODUCTION}

Soil degradation constitutes a grave environmental global issue, taking into account numerous negative implications ecologically and socio-economically. One of the causes of soil degradation is wind erosion. This phenomenon is growing in areas lacking tall vegetation, such as forests, especially in the fields of agriculture where soil degradation has a devastating impact on crops. The vegetal soil is gradually removed by wind erosion, leaving the land untouched and unproductive, the plants being unable to develop their roots, thus generating a decrease in the production of cereal and vegetable plants. Another effect caused by wind erosion is the rise of dust clouds. This phenomenon, once developed in populated areas, has a detrimental impact on the health of the human body due to inhalation of dust particles by humans. These non-organic particles once inhaled can cause lung problems and also other organs, such as the brain or the liver when the smaller particles are dissolved in the blood stream. Dust clouds can also affect air or road transportation, because particles suspended in the vicinity of an airport or motorway can make visibility more difficult and sometimes even make vehicles unable to move due to damage to their engines or their fuselage. Erosion has a negative socio-economic impact on the area affected by this phenomenon, which leads to the need to conduct different studies to establish some methods of controlling its effect. A method to avoid or mitigate negative effects is related to the use of protection barriers that play an essential role in 
establishing and maintaining ecological and socioeconomic equilibrium in the region. They have a key role to play in combating soil erosion, fixing sandy soils, protecting against mechanical damage to crops (by deflation), regulating soil moisture (by retaining snow in winter which is an essential spring moisture intake), stopping/reducing clogging local hydro-technical installations etc. [1-5]. Another method of limiting and even eliminating the effects of wind erosion of land is the one studied in this article and refers to the use of textile barriers placed perpendicular to the direction of the wind in order to reduce its intensity.

\section{NUMERICAL SIMULATION}

\section{Objective}

Wind erosion takes place through the entrainment of fine particles by the wind, these being transported, depending on their size and the intensity of the wind, by rolling, saltation or suspension, the latter being encountered in case of dust clouds. In order to eliminate the phenomenon, it is proposed to raise textile barriers in the wind direction in order to reduce the wind speed downstream of them, thus protecting the area of interest and diminishing the transport of the particles. Thus, for the numerical simulation in the present paper a calculation model will be made with the help of the ANSYS Fluent ${ }^{\mathrm{TM}}$ finite element calculation program which will track how the wind velocity is reduced downstream of the obstacle made of textile material at certain distances predetermined and for varying degrees of permeability. The results of the numerical tests will be presented synthetically in a table then in graphical form to highlight the way in which the wind speed is downgraded downstream of the permeable obstacle.

\section{Textile materials used in the tests}

To achieve the numerical experiment, five polypropylene (PE) textiles were proposed that are usually used in the medical field, each having a certain porosity and specific weight [6-7]. The porosity of the materials varies between $58 \%$ and $78 \%$ and can be found in table 1.

Table 1

PARTICULARITIES OF TEXTILE MATERIALS USED IN NUMERICAL TESTS

\begin{tabular}{|l|c|c|}
\hline \multicolumn{1}{|c|}{ Material } & Weight $\mathbf{( g / \mathbf { c m } ^ { 2 } )}$ & Porosity $\mathbf{( \% )}$ \\
\hline Gynemesh PS & 42 & 64 \\
\hline UltraPro & 28 & 69 \\
\hline SmartMesh & 19 & 78 \\
\hline Novasilk & 21 & 72 \\
\hline Polyform & 40 & 58 \\
\hline
\end{tabular}

\section{Numerical method used}

The phenomenon studied takes place inside the atmospheric boundary layer, the wind speed being directly influenced by the roughness of the land taken into consideration [8-11]. Thus, the calculation hypothesis will be for a flow in the turbulent field corresponding to the $k-\varepsilon$ model, with specific equations of this very common model used in Computational Fluid Dynamics (CFD) calculations. The geometry of the model is very simple, the flow domain being framed in a small side rectangle with a height of $200 \mathrm{~mm}$ and a length of $700 \mathrm{~mm}$. At a distance of $100 \mathrm{~mm}$ from the inlet, the permeable obstacle is found, having a height $H=40 \mathrm{~mm}$. The boundary conditions for the simulation are a constant velocity $v_{0}=21 \mathrm{~cm} / \mathrm{s}$ for the inlet (the left side of the rectangle), and a pressure $P_{\text {atm }}=0$ (zero) for the output from the domain (the rightmost side of the rectangle). The bottom side was modeled as a "wall" structure with the "no-slip" option enabled, which simulates the roughness of the land in the area of interest. The large opposite side of this, the upper boundary is of the "symmetry" type to simulate the atmospheric layer [6]. Also, for the fluid domain, the air density value $\rho=1.225 \mathrm{~kg} / \mathrm{m}^{3}$ and the air viscosity $\mu=1.7894 \mathrm{e}-05 \mathrm{~kg} /(\mathrm{m} \cdot \mathrm{s})$ were introduced. The permeable barrier was assigned, for each simulation performed, a different permeability, depending on the studied material. The study domain can be seen in figure 1.



Fig. 1. The geometry of the numerical simulation domain

For the boundary condition of the obstacle we used the "porous jump" option using the equation:

$$
\Delta p=-\left(\frac{\mu}{\alpha} v+C_{2} \frac{1}{2} \rho v^{2}\right) \Delta m
$$

where: $\mu$ is the viscosity of the fluid (air), $\alpha$-obstacle permeability (porosity), $C_{2}$ - pressure loss coefficient, $v$ - the velocity of the air flow perpendicular to the obstacle direction, $\rho$ - density of the fluid (air) and $\Delta m$ - the thickness of the porous obstacle.

The porous thin media has a finite thickness on which the pressure loss is produced, due to a combination of Darcy's law and an additional term of loss of inertia. As a result of the discretization (meshing) of the flow domain for the model, 297404 cells and 298701 nodes were produced (figure 2).



Fig. 2. The flow domain mesh 
After setting the mesh geometric model, and after setting the boundary conditions, we went to the next stage, namely the numerical calculations for each type of textile barrier used and its porosity and its effect upon the air velocity field.

\section{RESULTS AND DISCUSSIONS}

The results of the simulations can be seen in the below images, which contain a graphic for the wind velocity field for the $x$ direction (the air flow direction), for reference, for the barrier porosity $p=0 \%$ (figure 3), a graphic for the wind velocity field for $p=64 \%$ (figure 4), a table with the values of the average speed for certain predetermined heights in the model, and a series of graphs with the comparation of the results obtained for different porosity of the materials and their influence over the wind velocity field.

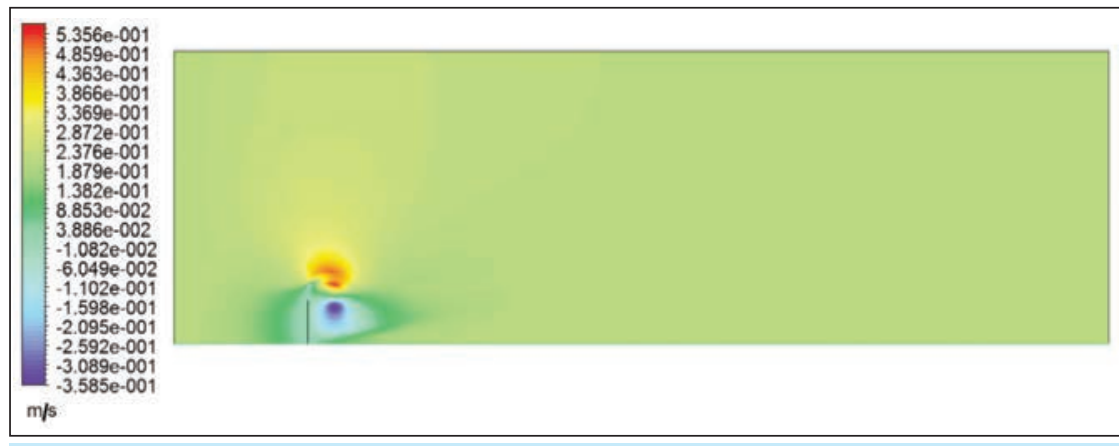

Fig. 3. The contour for the velocity field on $x$ direction, for barrier porosity $p=0 \%$

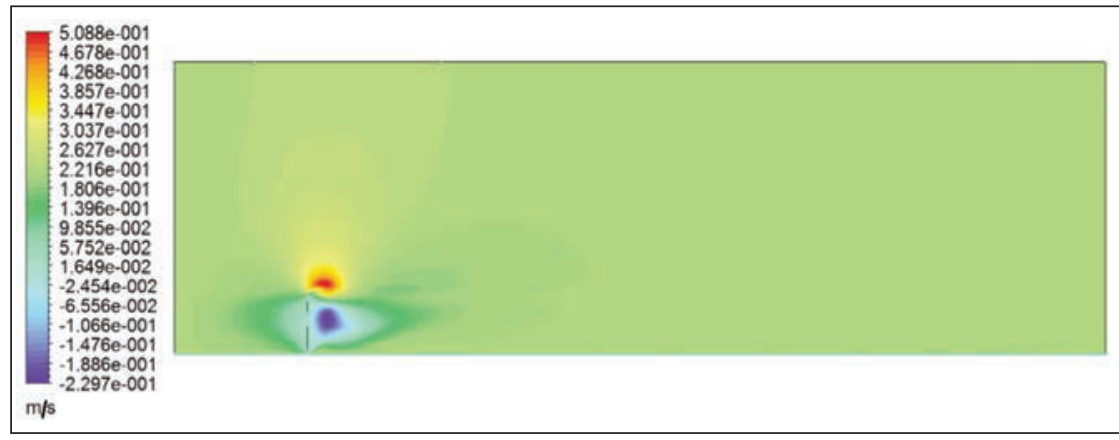

Fig. 4. The contour for the velocity field on $x$ direction, for barrier porosity $p=64 \%$

Table 2

\begin{tabular}{|c|c|c|c|c|c|c|c|c|c|c|c|c|}
\hline \multicolumn{13}{|c|}{$\begin{array}{c}\text { VALUES FOR WIND VELOCITY DOWNSTREAM OF THE BARRIER AT DIFFERENT HEIGHTS, IN REGARD } \\
\text { TO THE POROSITY OF THE MATERIAL (CM/S) }\end{array}$} \\
\hline \multirow{2}{*}{$\begin{array}{c}\text { Height } \\
(\mathrm{mm})\end{array}$} & \multicolumn{6}{|c|}{$x=0.25 H$} & \multicolumn{6}{|c|}{$x=0.50 H$} \\
\hline & $0 \%$ & $64 \%$ & $69 \%$ & $78 \%$ & $72 \%$ & $58 \%$ & $0 \%$ & $64 \%$ & $69 \%$ & $78 \%$ & $72 \%$ & $58 \%$ \\
\hline 0 & 4.59 & 0.92 & 0.92 & 0.91 & 0.92 & 0.92 & 7.76 & 0.89 & 0.89 & 0.89 & 0.89 & 0.89 \\
\hline 25 & 14.70 & 18.36 & 16.86 & 13.70 & 15.81 & 20.19 & 35.79 & 19.02 & 17.56 & 15.21 & 16.70 & 21.29 \\
\hline 50 & 47.92 & 49.86 & 48.57 & 46.12 & 47.71 & 51.32 & 50.03 & 44.21 & 42.53 & 40.01 & 41.56 & 46.83 \\
\hline 75 & 29.44 & 28.58 & 28.42 & 28.10 & 28.31 & 28.82 & 29.10 & 28.11 & 27.93 & 27.60 & 27.81 & 28.39 \\
\hline 100 & 26.02 & 25.62 & 25.53 & 25.37 & 25.48 & 25.74 & 25.85 & 25.50 & 25.42 & 25.25 & 25.36 & 25.63 \\
\hline 150 & 23.67 & 23.54 & 23.49 & 23.40 & 23.46 & 23.62 & 23.69 & 23.58 & 23.53 & 23.43 & 23.49 & 23.65 \\
\hline 200 & 23.09 & 22.99 & 22.96 & 22.88 & 22.93 & 23.06 & 23.09 & 23.00 & 22.97 & 22.89 & 22.94 & 23.06 \\
\hline \multirow{2}{*}{$\begin{array}{l}\text { Height } \\
(\mathrm{mm})\end{array}$} & \multicolumn{6}{|c|}{$x=1 H$} & \multicolumn{6}{|c|}{$x=1.5 H$} \\
\hline & $0 \%$ & $64 \%$ & $69 \%$ & $78 \%$ & $72 \%$ & $\%$ & $0 \%$ & $64 \%$ & $69 \%$ & $78 \%$ & $72 \%$ & $58 \%$ \\
\hline 0 & 12.97 & 0.91 & 0.91 & 0.91 & 0.91 & 0.91 & 15.08 & 0.90 & 0.90 & 0.90 & 0.90 & 0.90 \\
\hline 25 & 2.33 & 3.83 & 4.22 & 4.81 & 4.45 & 3.17 & 11.67 & 11.33 & 11.50 & 11.84 & 11.63 & 11.06 \\
\hline 50 & 27.90 & 23.23 & 23.06 & 22.85 & 22.97 & 23.55 & 20.27 & 18.71 & 18.71 & 17.73 & 18.71 & 18.73 \\
\hline 75 & 25.99 & 25.02 & 24.92 & 24.75 & 24.86 & 25.18 & 22.95 & 22.29 & 22.25 & 22.19 & 22.23 & 22.36 \\
\hline 100 & 24.97 & 24.65 & 24.58 & 24.45 & 24.54 & 24.75 & 23.69 & 23.29 & 23.25 & 23.16 & 23.22 & 23.36 \\
\hline 150 & 23.50 & 23.41 & 23.37 & 23.27 & 23.33 & 23.48 & 23.17 & 23.06 & 23.02 & 22.93 & 22.99 & 23.12 \\
\hline 200 & 23.02 & 22.92 & 22.88 & 22.81 & 22.86 & 22.97 & 22.85 & 22.70 & 22.67 & 22.61 & 22.65 & 22.76 \\
\hline \multirow{2}{*}{$\begin{array}{c}\text { Height } \\
(\mathrm{mm})\end{array}$} & \multicolumn{6}{|c|}{$x=2 H$} & \multicolumn{6}{|c|}{$x=4 H$} \\
\hline & $0 \%$ & $64 \%$ & $69 \%$ & $78 \%$ & $72 \%$ & $58 \%$ & $0 \%$ & $64 \%$ & $69 \%$ & $78 \%$ & $72 \%$ & $58 \%$ \\
\hline 0 & 15.70 & 0.90 & 0.90 & 0.90 & 0.90 & 0.90 & 17.02 & 0.89 & 0.89 & 0.89 & 0.89 & 0.89 \\
\hline 25 & 15.46 & 15.52 & 15.65 & 15.94 & 15.75 & 15.32 & 20.28 & 20.64 & 20.65 & 20.67 & 20.66 & 20.63 \\
\hline 50 & 18.98 & 18.25 & 18.29 & 18.36 & 18.31 & 18.21 & 20.31 & 20.44 & 20.45 & 20.48 & 20.46 & 20.41 \\
\hline 75 & 21.41 & 20.95 & 20.94 & 20.92 & 20.93 & 20.96 & 20.64 & 20.59 & 20.60 & 20.62 & 20.60 & 20.58 \\
\hline 100 & 22.57 & 22.19 & 22.17 & 22.12 & 22.15 & 22.23 & 21.05 & 20.95 & 20.95 & 20.95 & 20.95 & 20.95 \\
\hline 150 & 22.77 & 22.61 & 22.58 & 22.51 & 22.56 & 22.66 & 21.54 & 21.43 & 21.42 & 21.41 & 21.42 & 21.45 \\
\hline 200 & 22.61 & 22.45 & 22.42 & 22.36 & 22.40 & 22.49 & 21.63 & 21.52 & 21.51 & 21.49 & 21.50 & 21.53 \\
\hline
\end{tabular}




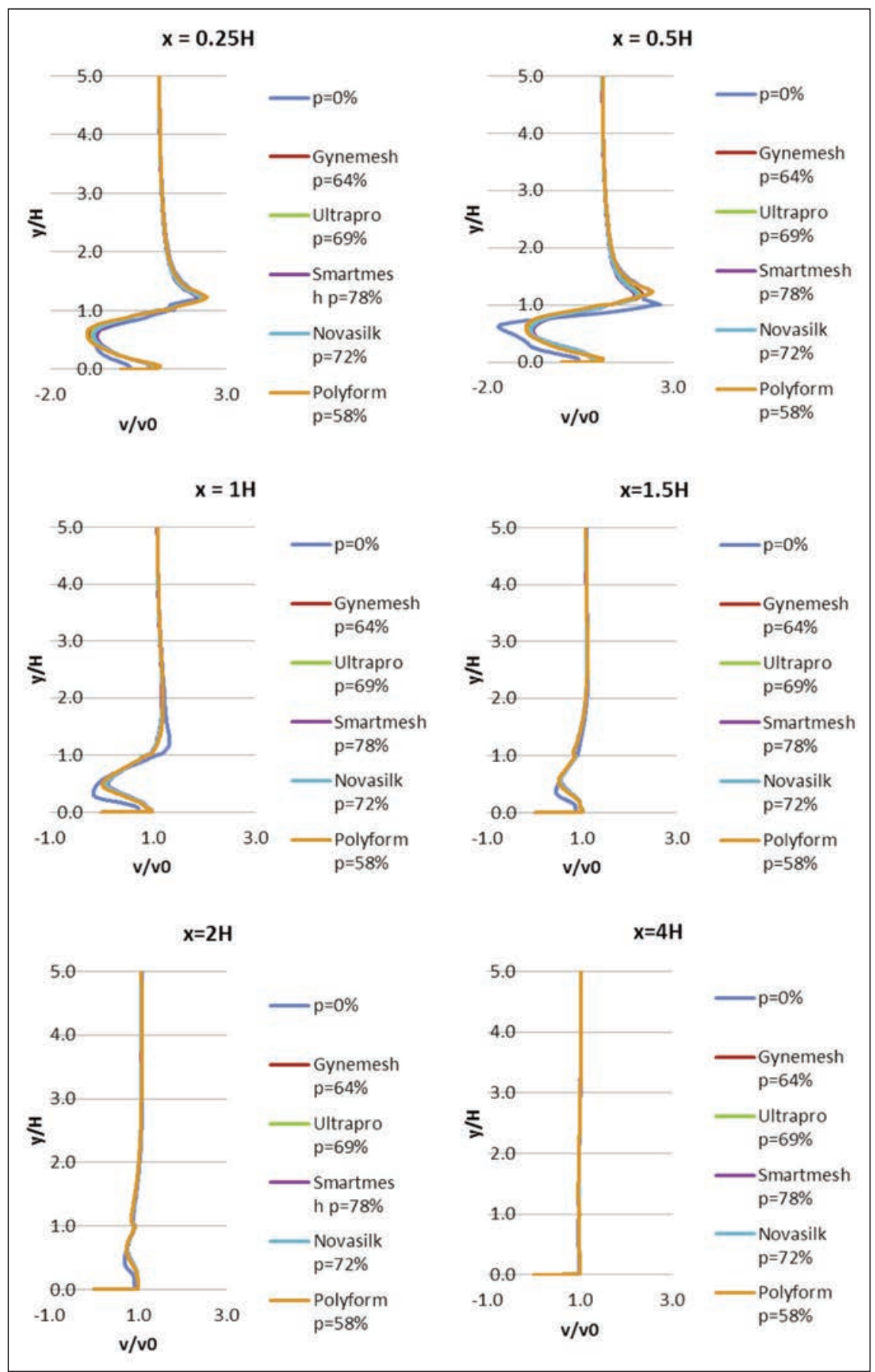

Fig. 5. Unadjusted speed for different porosity and distance from barrier (table 2) from which the values for drawing the graphs were taken in order to better visualize the obtained results. The graphs in figure 5 were made using unadjusted coordinates $v / v_{0}$ in the abscissa and $y / H$ in the ordered.

\section{CONCLUSIONS}

From the analysis of the results of the performed numerical tests, we can see that the $78 \%$ porosity is the most efficient in reducing the air velocity at the distance $x=0.25 \mathrm{H}$ and $x=0.5 \mathrm{H}$. For the $x=1 \mathrm{H}$ and $x=1.5 \mathrm{H}$ the porosity $58 \%$ is more efficient at the $25 \mathrm{~mm}$ height, but on average the $78 \%$ porosity is the best porosity to use, for all cases, including the $x=2 \mathrm{H}$ and $x=4 \mathrm{H}$, the later in which the flow velocity field resumes its normal course, the barrier no longer acting as an inertial loss for it. In order to validate the results obtained through the numerical tests and to capitalize on them, it will be possible to go further with the study of these simulations in the field of physical modeling, by carrying out experimental tests in the aerodynamic tunnel using these materials. Once these tests are carried out, the experimental results will be compared with the numerical ones, and the calculation model proposed in this paper will be updated and improved to simulate the phenomenon in nature. This will enable measures to be

After all the numerical simulations for the five types of textile materials used, a centralized table was created to highlight the results of the mathematical tests taken to reduce the effects of wind erosion in the areas affected by them using permeable protective barriers of textile material.

\section{REFERENCES}

[1] Lupe, I., Influenţa perdelelor forestiere asupra umezelii solului, In: Analele ICAS, 1951, 12, 1, 217-234

[2] Traci, C., Împadurirea terenurilor degradate, Ed. Ceres, Bucharest, 1985

[3] Neşu, I., Perdele forestiere de protecţie a câmpului, Ed. Star Tipp, Slobozia, 1999

[4] Nuță, S., Caracteristici structurale și funcționale ale perdelelor forestiere de protecție a câmpului agricol din sudul Olteniei, In: Analele ICAS, 2005, 48, 161-169

[5] Costăchescu, C., Dănescu, F., Mihăila, E., Perdele forestiere de protecţie, Ed. Silvică, Bucharest, 2010

[6] Feola, A., Barone, W., Moalli, P., Characterizing the ex vivo textile and structural properties of synthetic prolapse mesh products, In: International Urogynecology Journal, 2013, 24, 559-564 
[7] Yan, J., Quu, H., Numerical simulation of the effect of flow field in swirl nozzle spinning on yarn performance, In: Industria Textila, 2019, 70, 6, 564-571, http://doi.org/10.35530/IT.070.06.1422

[8] Degeratu, M., Hasegan, L., Alboiu, N., Bandoc, G., Modeling of the Atmospheric Boundary Layer using a Wind Tunnel with Discontinuity, In: Annals of DAAAM, 2010

[9] Degeratu, M., Georgescu, A.M., Bandoc, G., Alboiu, N.I., Cosoiu, C.I., Golumbeanu, M., Atmospheric boundary layer modeling as mean velocity profile used for wind tunnel tests on contaminant dispersion in the atmosphere, In: Journal of Environmental Protection and Ecology, 2013, 14, 1, 22-28

[10] Degeratu, M., Georgescu, A.M., Alboiu, N.I., Bandoc, G., Cosoiu, C.I., Golumbeanu, M., Turbulent structure of the wind flow and wind tunnel tests achieved for atmospheric contamination modelling, In: Journal of Environmental Protection and Ecology, 2013, 14, 2, 405-413

[11] Bandoc, G., Degeratu, M., Dragomir, E., Effect of wind turbulence on aeolian energy potential, In: Journal of Environmental Protection and Ecology, 2016, 17, 2, 541-548

Authors:

\section{BOGDAN-IULIAN DOROFTEI ${ }^{1}$, MIRCEA DEGERATU1 ${ }^{1}$, GEORGETA BANDOC², OVIDIU GEORGE IORDACHE ${ }^{3}$, IOANA CORINA MOGA 4}

${ }^{1}$ Department of Hydraulics and Environmental Protection, Technical University of Civil Engineering, Bucharest, Romania

${ }^{2}$ Department of Meteorology and Hydrology, University of Bucharest, Romania

${ }^{3}$ The National Research and Development Institute for Textiles and Leather, Bucharest, Romania

${ }^{4}$ Department of Research and Development, SC DFR Systems SRL, Bucharest, Romania

$$
\text { Corresponding author: }
$$

BOGDAN-IULIAN DOROFTEI

email: bogdan.doroftei@hotmail.com 


\title{
Antibacterial properties of wool fabrics treated with 8-hydroxyquinoline and boron compounds
}

\author{
DOI: $10.35530 / \mathrm{IT} .071 .02 .1542$
}

\section{ABSTRACT - REZUMAT}

\section{Antibacterial properties of wool fabrics treated with 8-hydroxyquinoline and boron compounds}

In this study, antibacterial properties of wool fabrics treated with 8-hydroxyquinoline (8HQ) and boron compounds were investigated against E. coli, B. subtilis, S. aureus and P. aeruginosa. Experimental group consisted of wool fabrics treated with $8 H Q$, boric acid $(B A)$ and borax $(B X)$ at $10 \mathrm{~g} / \mathrm{L}$ concentration for each using the exhaust process. Control group consisted of untreated and silver nitrate treated wool fabrics. Treatments were performed using meta- and premordanting methods and homogenous distribution of treatment chemicals were confirmed with SEM and EDX images. Wool samples treated with a solution containing $8 H Q+B X(10 \mathrm{~g} / \mathrm{L}$ each) and $8 H Q+B A+B X(10 \mathrm{~g} / \mathrm{L}$ each $)$ showed the highest level of antibacterial activity. Antibacterial activity decreased analogous with the decrease in $8 H Q$ concentration however it was still present at the lowest concentration of $1 \mathrm{~g} / \mathrm{L}$ for E. coli, B. subtilis and S. aureus. But at least $5 \mathrm{~g} / \mathrm{L}$ concentration of $8 \mathrm{HQ}$ was required for antibacterial activity against all four tested bacteria. Antibacterial properties decreased after 5 cycles of washing but did not completely disappear.

These antibacterial wool products look promising for the medical fields because of their strong effects against bacteria which grow in wounds and cause nosocomial infections. In addition, using the meta-mordanting method was more effective in terms of saving energy, water and time compared to the pre- mordanting method.

Keywords: antibacterial, boric acid, borax, wool, 8-hydroxyquinoline

Proprietăţile antibacteriene ale ţesăturilor din lână tratate cu 8-hidroxichinolină şi compuși ai borului

În acest studiu, proprietățile antibacteriene ale țesăturilor din lână tratate cu 8-hidroxichinolină (8HQ) și compuși ai borului au fost investigate împotriva E. coli, B. subtilis, S. aureus și P. aeruginosa. Grupul experimental a constat în țesături din lână tratate $\mathrm{cu} 8 \mathrm{HQ}$, acid boric (BA) și borax (BX) la o concentrație de $10 \mathrm{~g} / \mathrm{L}$, pentru fiecare folosindu-se procesul de epuizare. Grupul de control a fost format din țesături din lână netratate și, respectiv, tratate cu nitrat de argint. Tratamentele au fost efectuate folosind metode de meta- şi pre-mordansare, iar distribuția omogenă a substanțelor chimice de tratament a fost confirmată cu imagini SEM și EDX.

Epruvetele din lână tratate cu o soluție conținând $8 H Q+B X(10 \mathrm{~g} / \mathrm{L}$ fiecare) și $8 H Q+B A+B X(10 \mathrm{~g} / \mathrm{L}$ fiecare) au prezentat cel mai înalt nivel de activitate antibacteriană. Activitatea antibacteriană a scăzut odată cu scăderea concentrației de $8 \mathrm{HQ}$, cu toate acestea a fost prezentă și la cea mai mică concentrație de $1 \mathrm{~g} / \mathrm{L}$ pentru E. coli, B. subtilis și S. aureus. Dar, concentrația de cel puțin $5 \mathrm{~g} / \mathrm{L} 8 \mathrm{HQ}$ a fost necesară pentru activitatea antibacteriană împotriva tuturor celor patru bacterii testate. Proprietățile antibacteriene au scăzut după 5 cicluri de spălare, dar nu au dispărut complet. Produsele din lână cu proprietăți antibacteriene sunt promițătoare pentru domeniul medical datorită efectelor lor puternice împotriva bacteriilor, care se găsesc în răni și cauzează infecții nosocomiale. În plus, utilizarea metodei de meta-mordansare a fost mai eficientă în ceea ce privește economisirea de energie, apă și timp, comparativ cu metoda de pre-mordansare.

Cuvinte-cheie: antibacterian, acid boric, borax, lână, 8-hidroxichinolina

\section{INTRODUCTION}

8-Hydroxyquinoline is a small planar molecule with a lipophilic effect and a metal chelating ability. $8 \mathrm{HQ}$ is used in textile, wood, and paper industries because of its fungicide, insecticides, antibacterial and antimicrobial properties [1]. It is very effective against infection-causing pathogens and several bacteria [2]. 8HQ and its derivatives also have important properties that is useful in pharmacological and medicinal field acting as anti-neurodegenerative, anticancer, antioxidant, anti-inflammatory and anti-HIV agents.

Because of the proximity of the hydroxyl group to the heterocyclic nitrogen, $8 \mathrm{HQ}$ forms stable chelate complexes with various metal cations such as $\mathrm{Cu}^{2+}, \mathrm{Mn}^{2+}$, $\mathrm{Mg}^{2+}, \mathrm{Fe}^{3+}, \mathrm{Al}^{3+}, \mathrm{Zn}^{2+}$ [3-4]. Antibacterial effect of
$8 \mathrm{HQ}$ enhances when it makes complex with metal ions [5-6]. However, there are concerns about heavy metal ions associated with environment and health, so there is a need for more eco-friendly alternative for chelation with $8 \mathrm{HQ}$.

There are about 230 varieties of boron compounds in nature and they are being used for many years [7-8]. Some boron compounds show antifungal and antibacterial activities [9-10]. In addition, due to the presence of reduction, bleaching and flammability properties, they are frequently used in glass, ceramics, agriculture and textile sectors. Boron compounds are used in industry instead of many harmful substances because of their environmentally friendly characteristics [11-12]. Therefore, usage and importance 
of boron compounds in high-tech production are increasing day by day.

Wool fiber has a similar protein composition of the human skin surface [13]. It has been estimated that wool contains more than 170 different proteins. The proteins in wool are composed of amino acids, which show similar chemical properties to $8 \mathrm{HQ}$, especially in terms of chelate formation. Therefore, wool fiber, one of the natural textile fibers, was preferred for this research to be complexed with $8 \mathrm{HQ}$.

Aim of this research was to investigate the antibacterial properties of $8 \mathrm{HQ}$ treated wool fabrics for medical textile industry. Boric acid and borax were chosen as eco-friendly complexation agents to increase the antibacterial effect of the $8 \mathrm{HQ}$.

\section{EXPERIMENTAL WORK}

\section{Materials}

For this study, silver nitrate, 8-hydroxyquinoline $(8 \mathrm{HQ})$, boric acid $(\mathrm{BA})$, borax $(\mathrm{BX})$ and nitric acid were supplied from Merck, Germany. 100\% wool fabric was purchased from Yunsa, Turkey $\left(166 \mathrm{~g} / \mathrm{m}^{2}\right.$, 23 warp ends/cm, 24 weft ends/cm).

Biosan DEN1 model McFarland densitometer was used for estimating bacterial concentration. TERMAL B21606E model machine was used for washing of the samples. Morphological measurements and determination of elemental composition of the materials' surfaces were examined using FEI QUANTA FEG 250 model scanning electron microscope with EDX module.

\section{Bacterial strains and culture media}

Main cultures of Escherichia coli ATCC 35218, Bacillus subtilis ATCC 6633, Staphylococcus aureus ATCC 25293 and Pseudomonas aeruginosa ATCC 27853 were supplied from Microbiologics.

Nutrient broth and nutrient agar (for $E$. coli and $B$. subtilis strains) and Trypticase Soy Broth and Trypticase Soy Agar (used for $S$. aureus and $P$. aeruginosa strains) culture media were obtained from Hi-media.

\section{Methods}

Application of antibacterial agents on wool samples

After scouring with non-ionic detergent $(0.5 \%, \mathrm{w} / \mathrm{v})$ in the bath with $\mathrm{F}: \mathrm{L}$ (fabric to liquor ratio, w/v) 1:15 for $30 \mathrm{~min}$ at $60^{\circ} \mathrm{C}$, the wool fabric samples were treated with various chemicals (table 1 ) in accordance with the mordanting methods below. Several treatment solutions (baths) were prepared by dissolution of chemicals (table 1) in deionized water under magnetic stirring at room temperature. Silver treated, $8 \mathrm{HQ}$ treated and untreated wool samples were prepared for comparison.

"Mordanting" is a term commonly used in textile dyeing. A mordant is a chemical binding agent that adheres well to both fibers and dyes. The substances used for this purpose are called mordant substances. Classically defined, mordants are usually water-soluble metal salts and materials exhibiting weak acid or base properties. Wool is an example of natural textile materials that can form insoluble chelate complexes with various mordants including heavy metals [14]. Antimicrobial agents were applied on the fabrics using mordanting methods. Two baths were used in the pre-mordanting method [15], where fabrics were treated with $8 \mathrm{HQ}$ solution $(1-10 \mathrm{~g} / \mathrm{L})$ at the first bath, then with boron compounds $(10 \mathrm{~g} / \mathrm{L})$ at the second bath. At the meta-mordanting method, samples were treated in a single bath containing all the chemicals simultaneously. For each bath, the treatments were performed at $60^{\circ} \mathrm{C}$ for 30 minutes with a $F: L$ (weight of Fabric to volume of Liquor) of 1:20.

After the mordanting operations, treated woollen samples were washed with tap water in order to remove non-bonded chemical particles.

\section{Determination of antibacterial activity}

ISO 20645:2004 method was mimicked to determine the antibacterial activity of wool samples [16]. Two-layered soft agar plates were prepared by adding $7.5 \mathrm{~g} / \mathrm{L}$ Agar into the broth media, which were Nutrient Broth for E. coli and B. subtilis strains, Trypticase Soy Broth for $S$. aureus and $P$. aeruginosa. The lower layer was $10 \mathrm{ml}$ without any bacteria. The upper layer was $5 \mathrm{ml}$ and contained $100 \mu \mathrm{l}$ of the bacterial culture containing $10^{8} \mathrm{CFU} / \mathrm{ml}$ which was estimated from McFarland measurement $[15,17]$. Later, each wool sample to be tested were prepared in $30 \mathrm{~mm} \times 30 \mathrm{~mm}$ size and placed on the soft agar medium. Petri dishes were incubated at $37 \pm 1^{\circ} \mathrm{C}$ for 24 hours. For accuracy, the experiments were performed and repeated three times. Average diameters of inhibition zones were calculated using equation (1) [18]:

$$
A=(B-C) / 2
$$

where $A$ is the average diameter of clear inhibition zone in $\mathrm{mm}, \mathrm{B}$ - the total diameter of inhibition zone

Table 1

\begin{tabular}{|c|c|c|c|c|}
\hline \multicolumn{5}{|c|}{ STYPES AND CONCENTRATIONS (G/L) } \\
OF INGREDIENTS IN THE TREATMENT SOLUTIONS \\
\hline Samples & $\mathbf{8 H Q *}$ & $\begin{array}{c}\text { Silver } \\
\text { nitrate }\end{array}$ & $\begin{array}{c}\text { Borax } \\
\text { decahydrate }\end{array}$ & $\begin{array}{c}\text { Boric } \\
\text { acid }\end{array}$ \\
\hline W8 & 10 & - & - & - \\
\hline W8A & 10 & 10 & - & - \\
\hline WA & - & 10 & - & - \\
\hline W8B10 & 10 & - & 10 & - \\
\hline W8B5 & 5 & - & 10 & - \\
\hline W8B2.5 & 2.5 & - & 10 & - \\
\hline W8B1 & 1 & - & 10 & - \\
\hline W8BB10 & 10 & - & 10 & 10 \\
\hline W8BB5 & 5 & - & 10 & 10 \\
\hline W8BB2.5 & 2.5 & - & 10 & 10 \\
\hline W8BB1 & 1 & - & 10 & 10 \\
\hline
\end{tabular}

* $8 \mathrm{HQ}$ containing solutions were prepared by dissolution of $8 \mathrm{HQ}$ and other chemicals in deionized water acidified with nitric acid under magnetic stirring at room temperature. 
including wool sample and clear zone in $\mathrm{mm}$, and $\mathrm{C}$ - the length of the tested wool sample.

Antibacterial activities of the samples were tested before and after washing (up to 5 times) by using Standard Test Method ISO 105-C06 A1S [19]. After washing, the samples were rinsed in pure cold water, dried in the open air, and then tested for antibacterial activity as mentioned above.

\section{RESULTS AND DISCUSSIONS}

Surface morphology and elemental composition of the wool fibers

Surface morphologies and the elemental composition of the wool samples were investigated by SEM-EDX (table 2). Untreated wool (W0) surfaces had mole ratios of N/C, S/C and O/C which corresponded to $0.94,0.08$ and 1.98 respectively.

Treatment with $10 \mathrm{~g} / \mathrm{L} 8 \mathrm{HQ}$ solution (W8) resulted in a small decrease in N/C ratios while changes in $S / C$ mole ratios were insignificant. It was concluded that the $8 \mathrm{HQ}$ compound did not bind to the Sulphur in the $8 \mathrm{HQ}$ treated fabric (W8) due to the unchanged S/C ratio. Furthermore, EDX results showed that the oxygen content of the surfaces increased after $8 \mathrm{HQ}$ treatment (W8).

Samples treated with $8 \mathrm{HQ}$ and boron compounds (W8B1-10 and W8BB1-10) had homogenous boron distributions, which were confirmed by SEM-EDX mapping (figure 1). These samples had significantly decreased S/C mole ratios (from 0.08 to $0.02-0.04$ ), probably due to the homogenous distribution of boron compounds which covered surface of the 3Sulphur elements (figure 1). The change in $8 \mathrm{HQ}$ concentration of the treatment solutions from $10 \mathrm{~g} / \mathrm{L}$ to $1 \mathrm{~g} / \mathrm{L}$ decreased $\mathrm{N} / \mathrm{C}$ ratios proportionally while it did not have any significant effect on $B / C$ and $\mathrm{O} / \mathrm{C}$ ratios (table 2 ).

When SEM/EDX images of the wool fabric samples were examined (table 2 and figure 2), $8 \mathrm{HQ}$ treatment showed decrease in fiber diameter from $21.4 \mu \mathrm{m}$ (W0) to $17.7 \mu \mathrm{m}$ (W8). Fiber diameters were protected in the presence of boric acid in addition to $8 \mathrm{HQ}$ bath (W8B1-10). The highest fiber diameter was observed when
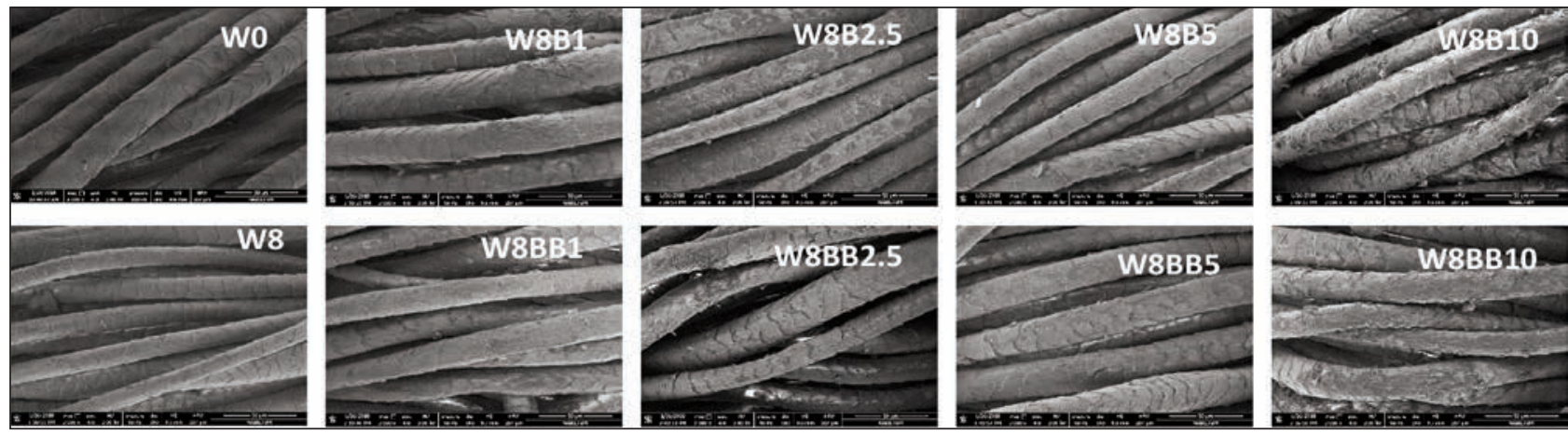

Fig. 2. SEM images of treated and untreated wool samples under $2000 \times$ magnification 
pre-mordanting method did probably due to dissolution of some $8 \mathrm{HQ}$ during the second bath process.

Examining the results shown in table 3 it can be concluded that the untreated wool sample (W0) was not effective against any of the bacteria tested. $8 \mathrm{HQ}$ by its own and $8 \mathrm{HQ}$ treated sample (W8) showed antibacterial activity against all the tested bacteria. The silver treated wool sample (WA) was effective only against gramnegative strains.

Wool fabric samples treated with $8 \mathrm{HQ}$ using the meta-mordanting method produced a $12 \mathrm{~mm}$ zone against $E$. coli. It was observed that while $8 \mathrm{HQ}$ concentration remained constant, addition of silver ions reduced the antibacterial effect of $8 \mathrm{HQ}$ by $40 \%$, whereas this effect increased when borax (W8B10) was used alone or together with borax/boric acid (W8BB10). For $P$. aeruginosa, the use of Ag, borax and boric acid + borax did not significantly change the antibacterial effect of $8 \mathrm{HQ}$. Taking all samples into consideration, it was determined that $P$. aeruginosa was the most resistant bacteria among the tested strains and the smallest zone diameters were observed at $P$. aeruginosa. These results are similar to the work of Srisung et al. (2013), who investigated the antibacterial effect of $8 \mathrm{HQ}$ on several bacteria and found that the most resistant bacteria is $P$. aeruginosa [2].

In the case of $B$. subtilis and $S$. aureus, the use of $\mathrm{Ag}$ generally decreased the antibacterial effect of $8 \mathrm{HQ}$ while the use of boron compounds with $8 \mathrm{HQ}$ increased this effect.

The highest antibacterial activity was observed at W8B10 and W8BB10 samples. Later, 8HQ concentration was decreased from $10 \mathrm{~g} / \mathrm{L}$ (W8B10 and W8BB10) to $1 \mathrm{~g} / \mathrm{L}$ (W8B1 and W8BB1) step by step in order to reduce production costs and observe the effects. At minimum $5 \mathrm{~g} / \mathrm{L} 8 \mathrm{HQ}$ concentration was required for antibacterial activity against $P$. aeruginosa while $1 \mathrm{~g} / \mathrm{L} 8 \mathrm{HQ}$ was enough against $E$. coli, B. subtilis and $S$. aureus (table 4).

The effect of 5-cycles of washing on the antibacterial activity was investigated (table 5). As seen in table 5, antibacterial effect decreased about $40-50 \%$ after 5 cycles of washing. Samples treated only with $8 \mathrm{HQ}$ (W8) were effective against all the bacteria except $P$. aeruginosa after washing.

It was also observed that all washed wool samples treated with $8 \mathrm{HQ}$ (W8, W8A, W8B and W8BB) were still more antibacterial than the non-washed silver treated samples (WA). This result shows that $8 \mathrm{HQ}$ has a critical role for antibacterial activity.

\section{CONCLUSIONS}

Aim of this study was to present antibacterial properties to wool samples by applying
Table 3

INHIBITION ZONE DIAMETERS (MM) CREATED BY THE TREATED SAMPLES USING META-MORDANTING AND PRE-MORDANTING (IN PARENTHESIS) METHODS

\begin{tabular}{|c|c|c|c|c|}
\hline \multirow{2}{*}{ Sample } & \multicolumn{2}{|c|}{ Gram-Negative Bacteria } & \multicolumn{2}{c|}{ Gram-Positive Bacteria } \\
\cline { 2 - 5 } & E. coli & P. aeruginosa & B. subtilis & S. aureus \\
\hline W0 & 0 & 0 & 0 & 0 \\
\hline 8HQ* & 35 & 3 & 39 & 18 \\
\hline W8 & 12 & 2 & 22 & 14 \\
\hline WA & 2 & 1 & 0 & 0 \\
\hline W8A & $7(5)$ & $4(3)$ & $8(6)$ & $4(3)$ \\
\hline W8B10 & $15(11)$ & $4(2)$ & $\geq 30^{* *}(25)$ & $8(6)$ \\
\hline W8BB10 & $18(13)$ & $4(2)$ & $\geq 30^{* *}(22)$ & $19(14)$ \\
\hline
\end{tabular}

* Zone diameter created by $10 \mu \mathrm{l}$ of $10 \mathrm{~g} / \mathrm{L} 8 \mathrm{HQ}$ solution.

** Full inhibition (no bacterial growth) was observed.

Table 4

INHIBITION ZONE DIAMETERS (MM) OF THE SAMPLES TREATED WITH VARIOUS CONCENTRATIONS OF 8HQ*

\begin{tabular}{|c|c|c|c|c|}
\hline \multirow{2}{*}{ Sample } & \multicolumn{2}{|c|}{ Gram-Negative Bacteria } & \multicolumn{2}{|c|}{ Gram-Positive Bacteria } \\
\hline & E. coli & $P$. aeruginosa & B. subtilis & S. aureus \\
\hline W8B10 & $15(11)$ & $4(2)$ & $\geq 30 *(25)$ & $17(12)$ \\
\hline W8B5 & $9(7)$ & $3(2)$ & $\geq 30 *(25)$ & $13(10)$ \\
\hline W8B2.5 & $7(5)$ & $0(0)$ & $22(16)$ & $8(6)$ \\
\hline W8B1 & $2(1)$ & $0(0)$ & $1(<1)$ & $8(6)$ \\
\hline W8BB10 & $18(13)$ & $4(2)$ & $\geq 30^{* *}(22)$ & $19(14)$ \\
\hline W8BB5 & $11(8)$ & $3(2)$ & $\geq 30^{* *}(20)$ & $17(13)$ \\
\hline W8BB2.5 & $6(4)$ & $0(0)$ & $29 \quad(21)$ & $13(10)$ \\
\hline W8BB1 & $2(1)$ & $0(0)$ & $1 \quad(<1)$ & $7(5)$ \\
\hline
\end{tabular}

* Used meta-mordanting (bold) and pre-mordanting (in parenthesis) methods.

** Full inhibition (no bacterial growth) was observed.

INHIBITION ZONE DIAMETERS (MM) OF 5-CYCLES WASHED WOOL SAMPLES*

\begin{tabular}{|c|c|c|c|c|}
\hline \multirow{2}{*}{ Sample } & \multicolumn{3}{|c|}{ Gram-Negative Bacteria } & \multicolumn{2}{c|}{ Gram-Positive Bacteria } \\
\cline { 2 - 5 } & E. coli & P. aeruginosa & B. subtilis & S. aureus \\
\hline W8 & 4 & 0 & 9 & 10 \\
\hline WA & 2 & 0 & 0 & 0 \\
\hline W8A & 3 & 2 & 3 & 2 \\
\hline \multicolumn{5}{|l}{} \\
\hline W8B10 & 9 & 2 & 18 & 11 \\
\hline W8B5 & 5 & 1 & 20 & 7 \\
\hline W8B2.5 & 3 & 0 & 12 & 5 \\
\hline W8B1 & 1 & 0 & 0 & 4 \\
\hline \multicolumn{5}{|l|}{} \\
\hline W8BB10 & 11 & 2 & 22 & 12 \\
\hline W8BB5 & 5 & 1 & 19 & 10 \\
\hline W8BB2.5 & 2 & 0 & 12 & 7 \\
\hline W8BB1 & 1 & 0 & 0 & 3 \\
\hline
\end{tabular}

* Metamordanting method was used for $8 \mathrm{HQ}$ treatment (bold). 
8hydroxyquinoline (8HQ) alone or together with boric acid and borax chemicals (experimental group). $8 \mathrm{HQ}$ and boron compounds were applied by using the premordanting (the application of boric acid + borax solutions to $8 \mathrm{HQ}$ applied wool fabric specimens) and the -meta-mordanting (the application of all chemicals at the same time) methods. Untreated- and silver nitrate treated-wool fabrics were used as the control group. Antibacterial activities of the samples against Gram-negative (E. coli and $P$. aeruginosa) and Gram-positive (B. subtilis and S. aureus) bacteria were investigated.

Untreated wool samples showed no antibacterial properties against any tested bacteria while Silver treated wool samples showed low levels of antibacterial activity against Gram (-) bacteria and no antibacterial effect against Gram (+) bacteria.

Among the samples in the experimental group, it was determined that the sample showing the highest antibacterial effect against all tested bacteria was W8BB10. When $8 \mathrm{HQ}$ concentration was reduced from $10 \mathrm{~g} / \mathrm{L}$ (W8BB10) until $1 \mathrm{~g} / \mathrm{L}$ (W8BB1), antibacterial activity decreased in a dose-dependent manner, while maintaining antibacterial activity in all strains except for $P$. aeruginosa. After 5 cycles of washing, the antibacterial activities decreased about $40-50 \%$, but the samples treated with $5 \mathrm{~g} / \mathrm{L}$ and higher concentration of $8 \mathrm{HQ}$ were still effective against all tested bacteria.

It was estimated that the industrial application of $8 \mathrm{HQ}$ as a mordanting agent on wool fabrics would acquire superior antibacterial properties than existing silver solutions in the market even after washing process. Silver treated wool samples were less effective against $P$. aeruginosa, which causes nosocomial infection, than $8 \mathrm{HQ}$ treated ones. Therefore, it was considered that $8 \mathrm{HQ}$ and boron containing formulations can be good candidates for application in the medical textiles sector. In addition, the meta-mordanting method required $50 \%$ less water and time for application in comparison to the pre-mordanting method thus it was shown that the meta-mordanting method is a more feasible and environmentally friendly process due to saving of water and energy.

\section{ACKNOWLEDGEMENTS}

The bacterial strains were kindly provided from Assoc. Prof. Asli Baysal at Istanbul Aydin University.

\section{REFERENCES}

[1] Short, B.R., Vargas, M.A., Thomas, J.C., et al., In vitro activity of a novel compound, the metal ion chelating agent $A Q+$, against clinical isolates of Staphylococcus aureus, In: Journal of Antimicrobial Chemotherapy, 2005, 57, 1, 104-109

[2] Srisung, S., Suksrichavalit, T., Prachayasittikul, S., et al., Antimicrobial activity of 8-hydroxyquinoline and transition metal complexes, In: International Journal of Pharmacology, 2013, 9, 2, 170-175

[3] Shoji, E., Miyatake, K., Hlil, A., et al., Immiscible polymers in double spin-coated electroluminescent devices containing phenyl-substituted tris (8-hydroxyquinoline) aluminum derivatives soluble in a host polymer, In: Journal of Polymer Science, Part A: Polymer Chemistry, 2003, 41,19, 3006-3016

[4] Albrecht, M., Fiege, M., Osetska, O., 8-Hydroxyquinolines in metallosupramolecular chemistry, In: Coordination Chemistry Reviews, 2008, 252, 8, 812-824

[5] Shah, S., Dalecki, A.G., Malalasekera, A.P., et al., 8-Hydroxyquinolines are boosting agents of copper-related toxicity in mycobacterium tuberculosis, In: Antimicrobial agents and chemotherapy, 2016, 60, 10, 5765-5776

[6] Prachayasittikul, V., Prachayasittikul, S., Ruchirawat, S., et al., 8-Hydroxyquinolines: a review of their metal chelating properties and medicinal applications, In: Drug design, development and therapy, 2013, 7, 1157-1178

[7] Shar, G., Soomro, G., 8-Hydroxyquinoline as a Complexing Reagent for the Determination of Cd (II) in Micellar Medium, In: Journal of the Chemical Society of Pakistan, 2005, 27, 5, 471-475

[8] Wang, H., Wang, W.S., Zhang, H.S., Spectrofluorimetic determination of cysteine based on the fluorescence inhibition of Cd (II)-8-hydroxyquinoline-5-sulphonic acid complex by cysteine, In: Talanta, 2001, 53, 5, 1015-1019

[9] De Seta, F., Schmidt, M., Vu, B., et al., Antifungal mechanisms supporting boric acid therapy of Candida vaginitis, In: Journal of antimicrobial chemotherapy, 2009, 63, 2, 325-336

[10] Yilmaz, M.T., Minimum inhibitory and minimum bactericidal concentrations of boron compounds against several bacterial strains, In: Turkish Journal of Medical Sciences, 2012, 42, 2, 1423-1429

[11] Buyukakinci, B.Y., Yilmaz, A., Investigation of Boric Acid and Sodium Borate Effect on Flame Retardancy of Cotton and Polyester Fabrics, In: Asian Journal of Chemistry, 2017, 29, 4, 893-895

[12] Buyukakinci, B.Y., Sökmen, N., Bayender, B., Effect of Sodium Borohydride on Microwave Assisted Reductive Cleaning of Dyed Polyester Fabrics, In: Asian Journal of Chemistry, 2016, 28, 12, 2752-2754

[13] Yu, D., Tian, W., Sun, B., et al., Preparation of silver-plated wool fabric with antibacterial and anti-mould properties, In: Materials Letters, 2015, 151, 1-4

[14] Bahtiyari, M.I., Yilmaz, F., Investigation of antibacterial properties of wool fabrics dyed with pine cones, In: Industria Textila, 2018, 69, 5, 369-374, http://doi.org/10.35530/IT.069.05.1516

[15] Buyukakinci, B.Y., Investigation of dyeing methods on wool fabrics with hibiscus and its antibacterial efficiency, In: Industria Textila, 2017, 68, 2, 103-107, https://doi.org/10.35530/IT.068.02.1288

[16] ISO 20645, Determination of antibacterial activity-agar diffusion plate test, In: Technical Committee CEN TC, 2004 
[17] McFarland, J., Standardization of bacterial culture for the disc diffusion assay, In: Journal of America Medical Association, 1987, 49, 1176-1178

[18] Kimiran Erdem, A., Sanli Yurudu, N.O., The evaluation of antibacterial activity of fabrics impregnated with dimethyltetradecyl (3-(trimethoxysilyl) propyl) ammonium chloride, In: IUFS Journal of Biology, 2008, 67, 2, 115-122

[19] ISO 105-C06 A1S, Tests for colour fastness - Part C06: Colour fastness to domestic and commercial laundering, In: Technical Committee, 2010

\section{Authors:}

TEZCAN ERDEM ${ }^{1}$, BÜYÜKAKINCI B. YEŞIM ${ }^{2}$

${ }^{1}$ Istanbul Gedik University, Faculty of Health Sciences, Department of Nutrition and Dietetics,

Cumhuriyet Mah., Ilkbahar Cd., no. 1, İstanbul, Turkey

${ }^{2}$ Istanbul Aydin University, Engineering Faculty, Textile Engineering,

Inonu Cd., no 38, İstanbul, Turkey

e-mail: byesimb2@gmail.com

Corresponding author:

TEZCAN ERDEM

e-mail: erdemtezcan@gmail.com 


\title{
Tensile and bending properties of flexible auxetic re-entrant honeycomb structures made by 3D printing
}

\author{
DOI: 10.35530/IT.071.02.1565
}

\section{ABSTRACT - REZUMAT}

Tensile and bending properties of flexible auxetic re-entrant honeycomb structures made by 3D printing

The main content dealt with in the paper was to present a flexible auxetic re-entrant honeycomb fabric, which was made of a formulated thermoplastic polyurethane material PolyFlex with super elastic properties by $3 D$ printing technology. The auxetic fabric shows perpendicular expansion under tension and is flexible. So, its special property makes auxetic fabric have great potential in future functional materials. Wherein, the honeycomb cell angle is a key factor affecting Poisson's ratio of fabric. In this paper, flexible re-entrant honeycomb structures with different cell angle are manufactured using 3D printing technology. The shape change under tension of two directions were investigated. The re-entrant honeycomb structures presented negative Poisson's ratio immediately when stretched. The shape change consisted of three stages in $X_{1}$-direction, the same as that in $X_{2}$-direction. A noticeable discovery was that the shape change in $X_{1}$-direction posed an out-plane change after the first shape change stage, while the shape change in $X_{2}$-direction always remained in-plane in the whole tension process. The tensile modulus tested was consistent with the tendency of theoretical analysis of previous work. The bending rigidities were tested and similar to fabrics of poplin and denim. The results indicate that the auxetic fabric is suitable for special clothing.

Keywords: flexible auxetic honeycombs, 3D printing, negative Poisson's ratio, shape change, bending rigidity

\section{Rezistenţă la rupere și rigiditatea la încovoiere ale structurilor auxetice flexible de tip fagure, realizate prin imprimare 3D}

Lucrarea analizează, în principal, materialul auxetic flexibil de tip fagure, realizat din poliuretan termoplastic tip PolyFlex cu proprietăți supraelastice, obținut prin tehnologia de imprimare $3 D$. Materialul auxetic prezintă expansiune pe direcție perpendiculară sub tensiune și este flexibil. Astfel, materialul auxetic prezintă un potențial mare pentru produsele funcționale viitoare. În acest caz, unghiul celulelor de tip fagure este un factor cheie care influențează raportul lui Poisson. În această lucrare, sunt prezentate structuri flexibile de tip fagure cu unghiuri diferite ale celulelor, realizate utilizând tehnologia de imprimare 3D. S-a analizat modificarea formei sub tensiune pe două direcții. Structurile de reumplere de tip fagure au prezentat un raport negativ al lui Poisson imediat după întindere. Modificarea formei a constat în trei etape pe direcția $X_{1}$ și asemănător pe direcția $X_{2}$. O descoperire vizibilă a fost aceea că modificarea formei în direcția $X_{1} s$-a realizat înafara planului, după prima etapă, în timp ce în direcția $X_{2}$ a rămas întotdeauna în planul întregului proces de tensiune. Modulul de rezistență la rupere testat a fost în concordanță cu tendința identificată în analiza teoretică din studiile anterioare. Rigiditățile la încovoiere au fost testate și au fost similare cu cele ale țesăturilor din poplin și denim. Rezultatele au indicat faptul că materialul auxetic este potrivit pentru realizarea îmbrăcămintei speciale.

Cuvinte-cheie: structuri auxetice flexibile de tip fagure, imprimare 3D, raportul lui Poisson negativ, modificarea formei, rigiditatea la încovoiere

\section{INTRODUCTION}

When a sample of material is stretched, it is naturally expected that a contraction in the direction perpendicular to the stretching direction will occur. Poisson's ratio is the quantity defining this fundamental material feature. On the contrary, a material with a negative Poisson's ratio expands in all directions when pulled, leading to an increase in its volume. Evans [1] was the first to make such materials as auxetic materials with a negative Poisson's ratio. Beside the elementary scientific importance of imparting such a fundamental property, a negative
Poisson's ratio can attribute a material with many exceptional benefits [2], such as increased stiffness [3], increased indentation resistance [4] and an ability to form synclastic doubly curved surfaces [5-6]. In recent years, the use of textile technology to fabricate auxetic materials has attracted more and more attention. It is reflected in the extent of research work exploring the auxetic potential of various textile structures and subsequent increase in the number of research papers [7]. Particularly, auxetic yarns have been studied thoroughly. Du manufactured helical auxetic yarns and analyzed the auxetic effect using 
finite element analysis based on ABAQUS software and theoretical formula [8]. Hu created a new method to manufacture auxetic yarns which had more stable structures, and manufactured a novel auxetic textile composites $[9,10]$ according to the re-entrant honeycomb structures. Ugbolue produced knit structures made of conventional yarns by using chain and filling yarn inlays. They combined the principles of geometry, fabric structural characteristics and conventional elastic yarn to engineer hexagonal knit structures with auxetic effect [11]. Recently, a range of auxetic knitted fabric had been produced by using weft flat knitting technology [12-13]. Based on rotating units, auxetic fabric was produced [14]. Verma reported that it was possible to induce out-of-plane auxetic behaviour in needle-punched nonwovens [15]. These auxetic textiles have great potential to be used in many areas like biomedical field, filters, piezoelectric sensors and actuators, medical field, seat belts and safety harness in automobiles, ballistic protection, reinforcement composites. Except the traditional textile technology, such as weaving [4], knitting [14, 16-18] and non-woven [19], 3D printing is a direct and effective method to fabricate complex auxetic structural designs. Meanwhile, auxetic materials can be used in smart systems and enforce composite materials [20-21].

Combinations of 3D printing with typical auxetic structures would also change the way of auxetic textiles manufacturing [22]. Actually, for the tension property of re-entrant honeycombs, the traditional auxetic structures of rigid materials had been investigated by scientists in the area of mechanical engineering [23-24]. All these articles dealt with the shape change under little strain and gave equations of Poisson's ratio and Yong's modulus. The Poisson' ratios of honeycombs were supposed to be determined by the geometry of their unit cells only. However, the shape change of flexible materials was a complex process, which call for intensive investigation in order to establish a proper understanding.

Therefore, the paper aims to produce a flexible auxetic re-entrant honeycomb fabric made of a formulated thermoplastic polyurethane material PolyFlex with super elastic properties by 3D printing technology, and to discover the tensile deformation of the auxetic fabric under two directions so as to analyze effect of cell angle on Poisson's ratio. In addition, the shape changes under tension of two directions were investigated in these flexible re-entrant cell honeycombs structures.

\section{EXPERIMENTAL DETAILS}

\section{Design of geometric unit cell parameters of re-entrant honeycomb structures}

Re-entrant honeycomb unit cell is characterized by four indices, i.e., cell wall of length $h$ and $I$, thickness $t$ and internal cell angle $\theta$ as seen in figure 1 . When the length $h$ and $/$ are fixed, the internal cell angle has significant effect on Poisson ratio. So, five typical internal cell angles $\theta$ are chosen as $-45^{\circ},-40^{\circ},-35^{\circ}$, $-30^{\circ},-25^{\circ}$, and the $h, I$ and $t$ are 10,5 and $0.6 \mathrm{~mm}$, respectively. The samples of tensile experiment were made in 5 unit cells'5 unit cells and two plain areas were added to the structures in order to measure conve-



Fig. 1. Unit cell of a model of re-entrant honeycomb structures niently. In addition,

tensile test on two directions $\left(X_{1}\right.$ and $X_{2}$ in figure 1) were carried out and illustrations of such sample tested in the two directions are shown in figure 2. For bending rigidity measurement, the samples are printed in $50 \mathrm{~mm} \times 200 \mathrm{~mm}$.



a

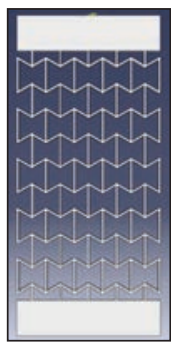

c

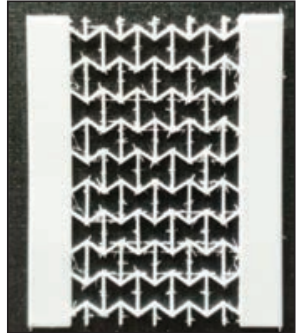

b

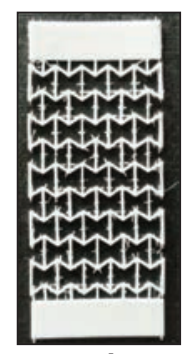

d
Fig. 2. A typical re-entrant structural model and sample: $a$ - model for tensile use in $X_{1}$ direction; $b$-sample for tensile use in $X_{1}$ direction; $c$ - model for tensile use in $X_{2}$ direction; $d$-sample for tensile use in $X_{2}$ direction

\section{D Printing process}

Twenty specimens were manufactured by Raise3D N2 system based on fused deposition modeling technique (FDM). The material used in this work was PolyFlex, which was a formulated thermoplastic polyurethane material with super elastic properties. The Young's Modulus of PolyFlex is $58.57 \mathrm{MPa}$ according to ASTM D638.

The manufacturing principle was based on a multi-jet modelling technology, where a special printing head covered the whole working area of $305 \mathrm{~mm} \times 305 \mathrm{~mm}$ $\times 305 \mathrm{~mm}$ and built up the model by adding individual layers of the produced geometry.

A SolidWorks parametric modeler was used to design the sample geometry, and then it was exported to the STL format for the 3D printing. The final samples were produced with a layer thickness of $0.1 \mathrm{~mm}$ and the total depth of each sample is $1.5 \mathrm{~mm}$. 


\section{Measurement method}

Tensile tests were implemented by YG026MB Fabric Strength Tester. The tensile speed was set to 200 $\mathrm{mm} / \mathrm{s}$. The Young's modulus $E$ was measured from the slope of the linear elasticity section on loaddeflexion curve (the strain from $0.1 \%$ to $0.3 \%$ ). In order to analyse the cell size change, a microfocus camera was employed to record the tensile deformation during the test until the out-of-plane change reached its maximum in the $X_{1}$-directional testing or the transverse width became smaller than $2 / 3$ of its original width in the $X_{2}$-directional testing, which the plane formed by $X_{1}$ and $X_{2}$ directions. Therefore, outof-plane shape change means change occurs on the planes perpendicular to the plane formed by $X_{1}$ and $X_{2}$ directions. Image process software DIGIMIZER was adopted to calculate the shape change in perpendicular direction, and the perpendicular strains and longitude strains were measured to calculate the Poisson's ratio of the honeycomb structures. Poisson's Ratio $u$ is defined as the minus of specific value between transverse strain and longitudinal strain in elastic loading.

Bending properties were implemented by FAST-2 Fabric bending tester and the bending meter measures two bending properties of a sample, namely the fabric bending length is related to the ability of a material to drape. The fabric bending rigidity relates to the quality of stiffness when a fabric is handled. The bending rigidity is particularly crucial in the tailoring of lightweight fabrics as a very flexible fabric (low bending rigidity) may cause seam puckering, while a high bending rigidity fabric can be more manageable in sewing and so produce a flat seam. The bending length $(B L)$ is displayed automatically [25-26].

\section{RESULTS AND DISCUSSIONS}

\section{The strain change in both directions}

It can be seen from figure $3, a$ and $b$ that the shape change of $3 \mathrm{D}$ printing honeycombs is distinct and

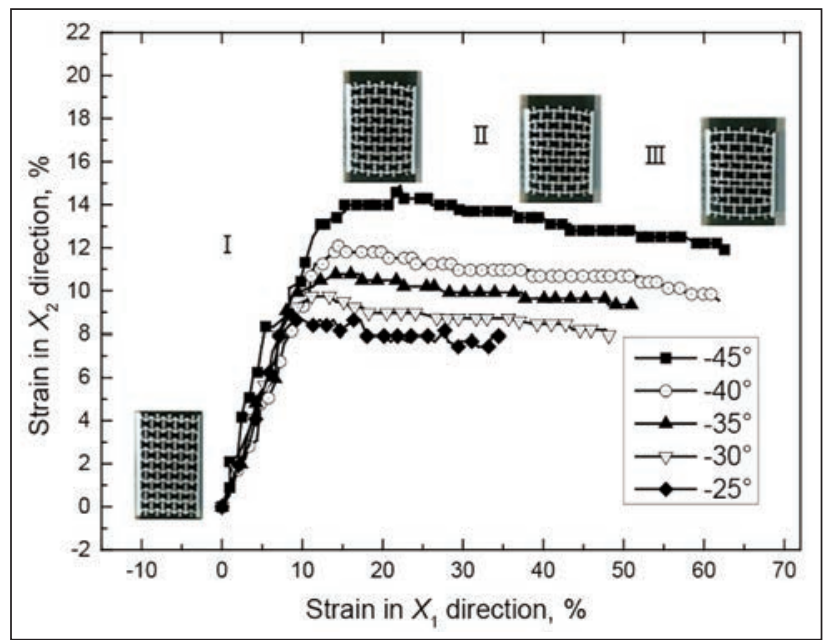

a they can show expanding in transverse direction at the same time of tension of longitudinal direction. The shape change process in $X_{1}$-direction consisted of three stages. In the first stage in figure $3, a$, shape change remained in-plane and the cell wall length I was almost parallel to the $X_{1}$-direction before reaching the highest strain for every sample. The out-plane shape change occurred in stage two, while out-plane shape change strain started decrease in stage three and the whole structure was broken in the edge.

The shape change in $X_{2}$-direction also included three stages, but it remained in-plane during the whole process. The first stage mainly consisted of the rotation of cell wall I and the perpendicular width reached its maximum and cell wall I was parallel to $X_{1}$-direction. After that, the perpendicular width remained wider than the original width, but it began to decrease at the second stage. It can see from figure $3, b$ that the re-entrant honeycomb structures would become an out-entrant honeycomb structures at the end of the second stage. The last stage of shape change in $X_{2}$-direction was simple, like a positive Poisson's ratio material.

At the edge of structures broken, the extending in $X_{2}$-direction was far bigger than that in $X_{1}$-direction. The perpendicular increasing under the tension in $X_{1}$-direction was much more steady, while the perpendicular increasing in $X_{2}$-direction increased with the increase of longitudinal increasing, and then decreased until smaller than the original width. There was also a distinct phenomenon that the tension in $X_{1}$-direction leading to an out-plane expanding, but the shape change in $X_{2}$-direction always remained inplane. We could discuss the out-plane shape change in these serials of paper.

\section{Typical Poisson's ratio-strain curve}

According to figure $4, a$ and $b$, the change of Poisson's ratio varies with the change of strain in different longitudinal directions. The Poisson's ratio had a closer relationship with the angle $\theta$. Obviously dif-

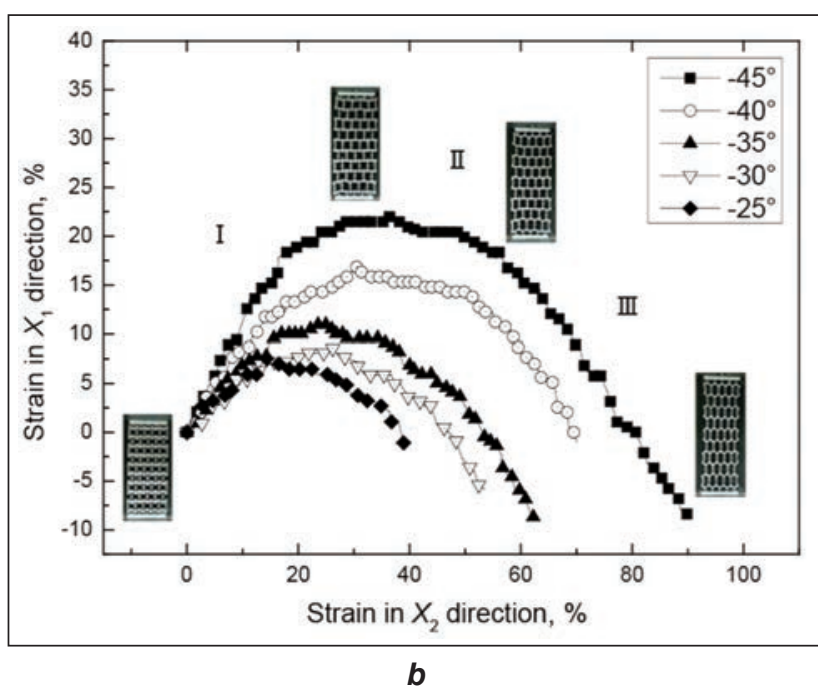

Fig. 3. The transverse strain vs. longitudinal strain in $X_{1}$ and $X_{2}$ directions: $a$ - tensile loading in $X_{1}$-direction; $b$ - tensile loading in $X_{2}$-direction 




a

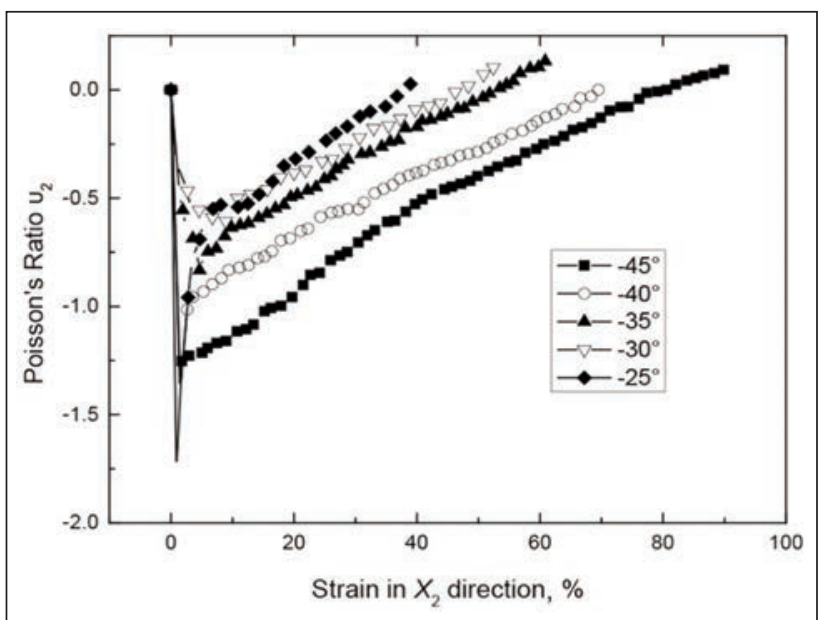

b

Fig. 4. The Poisson's ratio vs. longitudinal strain under tension for different cell angle: $a-$ tensile loading in $\mathrm{X}_{1}$ direction; $b$ - tensile loading in $\mathrm{X}_{2}$ direction

ferent samples had the smallest Poisson's ratio in different longitudinal strain, less than $10 \%$ in $X_{1}$-direction and less than $5 \%$ in $X_{2}$-direction. Meanwhile, the material properties were more important than the geometry parameters in the big strain area because the $v$ change tendencies are similar in all angles after the small strain change zones. And the re-entrant angle plays a more significant role in $X_{2}$-direction than in $X_{1}$-direction, which in same tensile strain, $20 \%$, the standard deviation of Poisson's ratio in $X_{1}$ direction is 0.12 , while 0.25 in $X_{2}$-direction.

In addition, there was a discovery that the Poisson's ratio was smaller in small angle $\theta$ under same strain within the second stage. At the initial stage, both shape change process in experiments were not very clear and experimental error was a little large. On the other hand, the most significant difference between figure $4, a$ and $b$ was the line tendency. In figure 4, $a$, the line changed in a shape of exponential form, while in figure $4, b$, the line was almost linear.

\section{Young's modulus}

It can be seen from figure 5 that the angle $\theta$ of the 3D printed flexible auxetic structures also had a significant effect on the Young's Modulus. The $E_{1}$ in direction of $X_{1}$ increased remarkably with the increase of angle $\theta$, while the $E_{2}$ in direction of $X_{2}$ was quite different, decreased slowly with the increase of angle $\theta$. They were almost equal in about angle $44^{\circ}$. The trend of $E$ change was consistent with the theoretical result of flexure model [24, 27].

\section{Bending rigidity}

It can be seen from table 1 that the bending rigidities and weight per square meter were given. As the cell angle increased, weight per square meter decreased dramatically. The bending rigidities were larger than the normal fabrics and were similar to the fabrics of poplin and denim [27-29]. The curves of bending rigidities were shown in figure 6 .
Table 1

WEIGHT PER SQUARE METER AND BENDING RIGIDITY OF SAMPLES

\begin{tabular}{|c|c|c|c|}
\hline $\begin{array}{c}\text { Angle } \theta \\
\left({ }^{\circ}\right)\end{array}$ & $\begin{array}{c}\text { Weight per } \\
\text { square meter } \\
\left(\mathrm{g} / \mathrm{m}^{2}\right)\end{array}$ & $\begin{array}{c}\text { B- } \mathrm{X}_{1} \text { direction } \\
(\mu \mathrm{N} \cdot \mathrm{m})\end{array}$ & $\begin{array}{c}\text { B- } \mathrm{X}_{2} \text { direction } \\
(\mu \mathrm{N} \cdot \mathrm{m})\end{array}$ \\
\hline$-45^{\circ}$ & 511.6 & 4869.70 & 4869.70 \\
\hline$-40^{\circ}$ & 446.9 & 5522.16 & 4253.47 \\
\hline$-35^{\circ}$ & 398.5 & 6101.58 & 3792.92 \\
\hline$-30^{\circ}$ & 352.5 & 4989.07 & 3669.31 \\
\hline$-25^{\circ}$ & 317.2 & 4732.15 & 3205.74 \\
\hline
\end{tabular}

It is obvious from figure 6 that the bending rigidity in $X_{1}$ direction reached its top when the angle was -35 , while it remained decrease constantly in $X_{2}$ direction. It may be attributed to different parts of the re-entrant structures. For the bending in $X_{1}$ direction, the inclined edges with length / loaded more and the shape change process was complicate. On the other

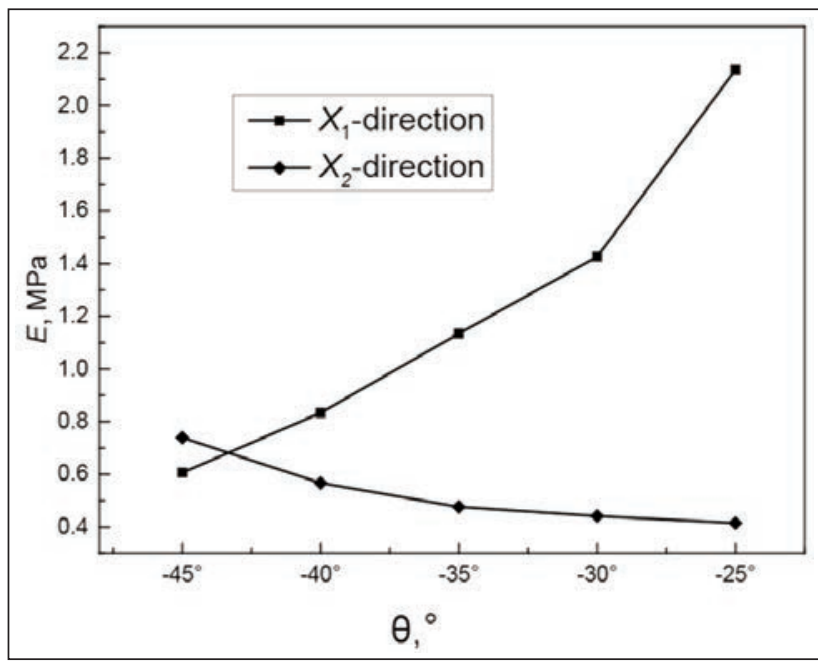

Fig. 5. The Yong's module of different samples 


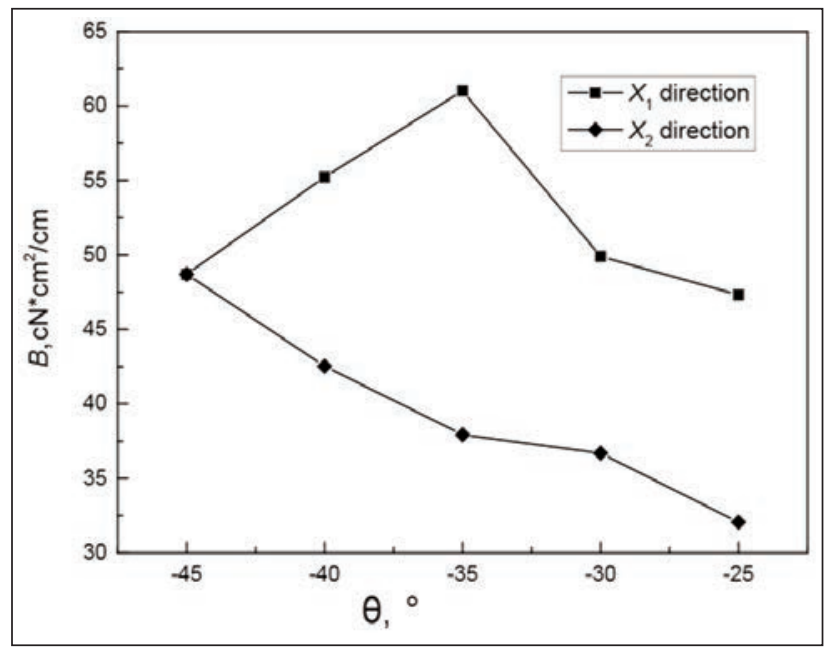

Fig. 6. Bending rigidities of samples

hand, the bending behaviour in $X_{2}$ direction was caused mainly by the bending of cell walls with length $h$, and it was more like a beam bending.

When the comparisons were made between figure 5 and figure 6 , there was a discovery that in the angle of $-45^{\circ}$, the bending rigidities in two directions were same, and the Young's modulus were also close for the two directions.

\section{CONCLUSION}

The samples of flexible re-entrant honeycomb structures were manufactured by 3D printing technology.
Through using microfocus camera and software DIGIMIZER, the process of shape change was investigated. They both express negative Poisson's ratio. Meanwhile, the honeycomb structures can show negative Poisson's ratio at the same time of loading. The shape change process was different in two tension directions. When the load was possessed in $X_{1}$-direction, the honeycomb structures would expand and showed out-plane negative Poisson's ratio, while if the load was possessed in $X_{2}$-direction, the honeycomb structures would perpendicularly expand and then contract, meanwhile, the shape change process remained in-plane. The Young's module increased with the increase of angle in $X_{1}$-direction; while decreased with the increase of angle in $X_{2}$-direction. This was consistent with theoretical analysis in former papers. The bending rigidity of $3 \mathrm{D}$ printed fabrics was similar to the fabrics of poplin and denim. Finite element analysis of the structures will be done in next paper.

\section{ACKNOWLEDGEMENT}

This work is jointly supported by Jiangxi Provincial Bureau for Quality and Technical Supervision (GZJKY201807), Jiangxi Provincial Administration for Market Regulation (GSJK201909) and "The Fundamental Research Funds for the Central Universities (CUSF-DH-D-2017021)". One of the authors (Qiaoli Xu) gratefully acknowledges the scholarship from the China Scholarship Council (No 201706630070).

\section{REFERENCES}

[1] Evans, K.E., Alderson, A., Christian, F.R., Auxetic two-dimensional polymer networks. An example of tailoring geometry for specific mechanical properties, In: Journal of the Chemical Society, Faraday Transactions, 1995, 91, 16, 2671-2680

[2] Umakiran, T., Kumar, A.A., Auxetic textile and its applications, In: Man-Made Textiles in India, 2009

[3] Evans, K.E., Alderson, K.L., Auxetic materials: the positive side of being negative, In: Engineering Science and Education Journal, 2000, 9, 4, 148-154

[4] Alderson, A., A triumph of lateral thought, In: Chemistry and Industry (London), 1999, 10

[5] Yang Z., Deng, Q., Merchanical property and application of materials and structures with negative Poisson's Ratio, In: Advances in Mechanics, 2011, 3, 335-350

[6] Evans, K., Tailoring the negative Poisson ratio, 1990

[7] Rant, D., Rijavec, T., Pavko-Čuden, A., Auxetic textiles, In: Acta Chimica Slovenica, 2013, 60, 4, 715-723

[8] Du, Z., et al., Study on negative Poisson's ratio of auxetic yarn under tension: Part 1 - Theoretical analysis, In: Textile Research Journal, 2015, 85, 5, 487-498

[9] Ge, Z., Hu, H., Liu, S., A novel plied yarn structure with negative Poisson's ratio, In: Journal of the Textile Institute, $2015,1-11$

[10] Ge, Z.Y., Hu, H, Design and compression deformation analysis of an innovational structure with auxetic effect, In: Applied Mechanics and Materials, 2013, 99-103

[11] Ugbolue, S.C., et al., Auxetic fabric structures and related fabrication methods, US, 2014

[12] Liu, Y., et al., Negative poisson's ratio weft-knitted fabrics, In: Textile Research Journal, 2010, 80, 9, 856-863

[13] Liu, Y., Hu, H., A review on auxetic structures and polymeric materials, In: Scientific Research and Essays, 2010, $5,10,1052-1063$

[14] Hu, H., Wang, Z., Liu, S., Development of auxetic fabrics using flat knitting technology, In: Textile Research Journal, 2011, 81, 14, 1493-1502

[15] Verma, P., et al., Inducing out-of-plane auxetic behavior in needle-punched nonwovens, In: Physica Status Solidi (B) Basic Research, 2015, 252, 7, 1455-1464

[16] Ma, P., Chang, Y., Jiang, G., Design and fabrication of auxetic warp-knitted structures with a rotational hexagonal loop, In: Textile Research Journal, 2015, 86, 20, 2151-2157 
[17] Steffens, F., Rana, S., Fangueiro, R., Development of novel auxetic textile structures using high performance fibres, In: Materials \& Design, 2016, 106, 81-89

[18] Ugbolue, S.C., et al., The Formation and Performance of Auxetic Textiles, In: Journal of the Textile Institute, 2000, $102,5,424-433$

[19] Verma, P., et al., Induction of auxetic response in needle-punched nonwovens: Effects of temperature, pressure, and time, In: Physica Status Solidi, 2016

[20] Scarpa, F., et al., Auxetics in smart systems and structures 2015, In: Smart Materials and Structures, 2016, 25, 5

[21] Zorzetto, L., Ruffoni, D., Re-entrant inclusions in cellular solids: From defects to reinforcements, In: Composite Structures, 2017, 176, 195-204

[22] Grimmelsmann, N., Meissner, H., Ehrmann, A., 3D printed auxetic forms on knitted fabrics for adjustable permeability and mechanical properties, In: IOP Conference Series: Materials Science and Engineering, 2016

[23] Gibson, L.J., et al., The Mechanics of Two-Dimensional Cellular Materials, In: Proceedings of the Royal Society A, 1982, 382, 1782, 25-42

[24] Masters, I.G., Evans K.E., Models for the elastic deformation of honeycombs, In: Composite Structures, 1996, 35, 4, 403-422

[25] Minazio, P.G., FAST - Fabric Assurance by Simple Testing, In: International Journal of Clothing Science \& Technology, 1995, 7, 2/3, 43-48

[26] Barndt H., et al., The Use of KES and Fast Instruments, In: International Journal of Clothing Science \& Technology, 1990, 2, 3, 34-39

[27] Liu, C., Han, Y., Zhang, C., Test Method for Fabric Bending Behavior Based on Image Processing, In: Journal of Textile Research, 2013, 34, 7, 52-56

[28] Du, Z., Yu, W., Hamada, H., Analysis of structure and bending property of spacer fabric composites, In: Industria Textila, 2011, 62, 2, 64-71

[29] Du, Z., Shen, Hu., Zhou, T., Yu, W., Comparison of properties characterization between CHES-FY, KES-F and FAST, In: Industria Textila, 2011, 62, 3, 123-128

Authors:

DU ZHAOQUN ${ }^{1}$, XU QIAOLI², GU LONGXIN², ZHENG DONGMING ${ }^{3}$, WANG QICAI ${ }^{4}$

${ }^{1}$ Key Laboratory of Textile Science \& Technology (Donghua University), Ministry of Education, College of Textiles, Donghua University, 201620, Shanghai, China

${ }^{2}$ College of Textiles, Donghua University, 201620, Shanghai, China,

e-mail: 1159114@mail.dhu.edu.cn,1169134@mail.dhu.edu.cn

3 Jiangxi Provincial Center for Quality Inspection and Supervision on Down Products, 332020, Jiangxi Gongqingcheng, China e-mail: zhongdm@139.com

${ }^{4}$ Lutai School of Textile and Apparel, Shandong University of Technology, 255000, Shandong Zibo, China e-mail: qcwang@sdut.edu.cn

Corresponding author:

DU ZHAOQUN

e-mail: duzq@dhu.edu.cn 


\section{Perceived stress: role and levels of demographics - a cross-sectional study of textile industry employees}

DOI: $10.35530 / I T .071 .02 .1643$

\section{Perceived stress: role and levels of demographics - a cross-sectional study of textile industry} employees

Work stress adversely affects individual and organizational performance. This paper aims at investigating the perceived stress among the employees of textile industry employees and how the employees' perceived stress level (EPSL) is linked with different demographic variables. Data was collected from 1212 employees working in 23 export-based textile organizations using primarily Sheldon Cohen's PSS-10. Descriptive analysis, t-tests, and ANOVA-tests were performed to achieve the objectives of the study. $70 \%$ of the participants were found to be undergoing stress amongst $21 \%$ were in the severe level of stress while $40 \%$ in higher level. The demographic variables: gender, marital status, salary, position, job experience, family size, and size of the organization, were found to have significant effect on the perceived stress levels. The study revealed numbers of variables (demographic) that directly or indirectly affect the employees' perceived stress level (EPSL). There is a need to understand the complexity of stress phenomenon using a proactive approach, so that the stress management and interventions strategies can be designed to be effective and implemented accordingly. Findings of this research support the research community in an attempt to unfold complexity of stress phenomenon and study results can be utilized as a job design guideline for more acceptable and viable stress management interventions.

Keywords: demographics, employees, PSS-10, perceived stress, textile

\section{Stresul perceput: rolul și nivelurile demografice - un studiu transversal asupra angajaților din industria textilă}

Stresul de la locul de muncă afectează negativ performanțele individuale și organizaționale. Acest articol are ca obiectiv analiza stresului perceput în rândul angajaților din industria textilă și modul în care nivelul de stres perceput al angajaților (EPSL) este influențat de diferite variabile demografice. Datele au fost colectate de la 1212 angajați, care lucrează în 23 de organizații în domeniul exportului de produse textile, folosind în principal indicatorul PSS-10 al lui Sheldon Cohen. Analiza descriptivă, testele-t și testele ANOVA au fost efectuate pentru a atinge obiectivele studiului. S-a constatat că $70 \%$ dintre participanți suferă de stres, dintre care $21 \%$ au prezentat un nivel sever de stres, iar $40 \%$ un nivel superior de stres. Variabilele demografice: sexul, starea civilă, salariul, funcţia, experiența la locul de muncă, numărul de membri ai familiei și mărimea organizației influențează semnificativ nivelurile de stres percepute. Studiul a relevat un număr de variabile (demografice), care influențează direct sau indirect nivelul de stres perceput de către angajați (EPSL). Este necesară înțelegerea complexității fenomenului de stres folosind o abordare proactivă, astfel încât gestionarea stresului și strategiile de intervenție să fie eficiente și implementate în consecință. Concluziile acestei cercetări susțin comunitatea de cercetare în încercarea de a analiza complexitatea fenomenului de stres, iar rezultatele studiului pot fi utilizate ca ghid de proiectare a locului de muncă pentru intervenții viabile de gestionare a stresului.

Cuvinte-cheie: demografie, angajați, PSS-10, stresul perceput, textile

\section{INTRODUCTION}

\section{Background and objectives of the study}

Work stress is a global issue. In Great Britain, in the year 2017-2018: work-related stress, anxiety or depression were found as major causes for $44 \%$ of the work-related ill-health cases where about $57 \%$ of the working days were found to be lost because of health-related issues [1]. The textile industry is considered as one of the largest manufacturing industries in Pakistan. The sector supports $8.5 \%$ to the gross domestic product (GDP) and is a source of employment to about $30 \%$ of the 49 million workforce of the country. With fifty two percent of total exports, it continues to be the mainstay of the country's exports [2]. Work stress has become a major issue for the organizations where textile organizations have no exemption. This research aims at investigating the intensity of perceived stress among the employees of textile industry organizations and how perceived stress is linked with different demographic variables. The study is a part of a big research project of which three of the works have already been published [3-5], with novel major parts presented in this paper. 
Stress affects the human body adversely and results in work-related musculoskeletal disorders (WMSDs) and impacts individual and organizational work performance negatively [6-8]. It results in reduced efficiency, reduced capacity for work schedules, diminished zeal or work devotion, lack of creativity, absence of compassion for the organization, lost commitment, self-esteem, and increased occurrence of "perceived contract breach" [9-12]. It can easily be concluded that stress has its effects on all the functions being performed in an organization and due deliberation ought to be given to manage it.

\section{Literature review and research gap}

Several studies have been performed to determine individuals' perceived stress levels and their association with the group demographics. The demographics of the players and entrepreneurs were found to play a major role in perceiving the impacts of stressors [13-14]. Women were reported to be more stressful than men [4,15-17]. Likewise, single employees have been found to be more stressful than married [1]. Increases in the educational level of the participants, has been found associated with a decrease in their perceived stress scores [1]. A study on radiographers revealed that $63 \%$ of the subjects indicated high to severe levels of stress [16] whereas another performed on textile workers yielded $28 \%$ as stressful [18]. A positive correlation was found between HRST (Human Resource in Science and Technology) and innovative projects while it was not found between people with tertiary education and innovative process [2]. Major emphasis in the earlier stress related studies has been seen in sports, medical services, and employment in a broad-spectrum besides some segments like teaching [9, 19-21]. The stress literature on the textile industry employees is very limited and the available literature does not cover the sector as a whole [22] whereas this study encompasses the entire area of the textile industry. In Pakistan textile and clothing sector, there is a need to deploy efficient research and development activities [23]. The present study attempts to unfold work stress phenomenon.

\section{METHOD}

\section{Participants}

In the study, 1212 personnel from 23 diverse organizations were randomly selected for the data collection. The employees who were the subjects for this research worked at all levels in the four major areas of the textile sector, explicitly: fiber and fabric manufacturing; apparel manufacturing; socks manufacturing; and home textiles. They were from different functioning areas of the establishments (see table 1).

\section{Survey}

So as to reach the desired objectives of this crosssectional study, information was gathered through a survey. Earlier, trained staffs talked to each participant about the rationale of the research and how to record the responses. Respondents were informed that the data collection was anonymous and no specific information would be shared with anyone at any stage of the research and the information would be used only for research purposes.

\section{Instrument}

The instrument consisted of Cohen's Perceived Stress Scale-10 (PSS-10) [24] and nine demographic variables. PSS-10 is one of the scales commonly used to record the individuals' perceived stress levels. Since its development in 1983, it has been a widely used by the researchers to evaluate individuals' and group stress levels [25-26]. In the PSS-10 part of the instrument, subjects answered on a 5-point scale which ranged from 0 (never) to 4 (always), 0 indicating No Stress and 4 indicating High Stress. The subjects were supposed to go for any number of the scale as per their responses. The responses to 10 questions were subsequently summed to generate the perceived stress score, where higher scores indicate greater psychological stress. The internal consistency of the PSS-10 part of the instrument was checked through Cronbach's alpha and found reliable with the value of 0.74 .

\section{Statistical procedures}

Descriptive analysis, independent sample t-test, and a One-Way between subjects ANOVA using the SPSS 23.0 were deployed to measure the employees' perceived stress level (EPSL) and to identify the role of demographics on it.

\section{RESULTS AND DISCUSSION}

\section{Perceived stress}

Psychological stress has been shown to contribute to poorer health practices, augmented disease risk, more frequent health service consumption, and increased mortality [30].

\section{PSS scores}

The total PSS score mean was 14.59 while it was 14.43 for male and 15.70 for female employees, table 1. A trend of decrease in stress appeared with an increase in educational level excluding graduates and postgraduates. Stress score was higher for workers (15.48) and lower for supervisors (13.22). A similar trend was seen for job experience where mean PSS score decreased with increase in job experience exclusive of above 15 years.

\section{Perceived stress levels}

There are no cut-offs in the PSS scores, there are only comparisons between people within the sample [27]. Thus, for the purpose, individuals' perceived stress scores were interpreted as $0-7=$ no stress, 8-11 = low stress, 12-15 = moderate stress, 16-20 = high stress, $21+=$ severe stress [4]. Subsequently, table 1, figures 1 and 2 show statistics of the employees referring to their perceived stress levels. In further 


\begin{tabular}{|c|c|c|c|c|c|c|c|c|c|}
\hline \multicolumn{10}{|c|}{ DEMOGRAPHICS, PERCEIVED STRESS SCALE SCORES AND EMPLOYEES CATEGORY $(\mathrm{N}=1212)$} \\
\hline \multirow{3}{*}{\multicolumn{2}{|c|}{ Demographics }} & \multicolumn{2}{|c|}{ Frequency } & \multicolumn{2}{|c|}{ PSS score } & \multicolumn{4}{|c|}{$\begin{array}{c}\text { Employees category with respect } \\
\text { to stress }\end{array}$} \\
\hline & & \multirow{2}{*}{ No. } & \multirow{2}{*}{ Percentage } & \multirow{2}{*}{ Mean } & \multirow{2}{*}{$\begin{array}{l}\text { Standard } \\
\text { deviation }\end{array}$} & \multicolumn{2}{|c|}{ Not stressful } & \multicolumn{2}{|c|}{ Stressful } \\
\hline & & & & & & No. & Percentage & No. & Percentage \\
\hline \multirow{2}{*}{ Gender } & Male & 1059 & 87.4 & 14.43 & 5.43 & 325 & 30.7 & 734 & 69.3 \\
\hline & Female & 153 & 12.6 & 15.7 & 6.01 & 39 & 25.5 & 114 & 74.5 \\
\hline \multirow{3}{*}{$\begin{array}{l}\text { Marital } \\
\text { status }\end{array}$} & Married & 903 & 74.5 & 14.24 & 5.41 & 298 & 33 & 605 & 67 \\
\hline & Single & 299 & 24.7 & 15.49 & 5.64 & 66 & 22.1 & 233 & 77.9 \\
\hline & Others & 10 & 0.8 & 19.6 & 6.88 & 0 & 0 & 10 & 100 \\
\hline \multirow{6}{*}{ Department } & HR & 56 & 4.6 & 14.42 & 6.77 & 21 & 37.5 & 42 & 62.5 \\
\hline & $\begin{array}{l}\text { Accounts and } \\
\text { finance }\end{array}$ & 43 & 3.5 & 14.72 & 5.17 & 13 & 30 & 30 & 70 \\
\hline & \begin{tabular}{|l|}
$\begin{array}{l}\text { Marketing and } \\
\text { export }\end{array}$ \\
\end{tabular} & 87 & 7.2 & 14.85 & 5.57 & 25 & 29 & 62 & 71 \\
\hline & Production & 909 & 75 & 14.69 & 5.45 & 263 & 29 & 646 & 71 \\
\hline & Administration & 42 & 3.5 & 13 & 5.69 & 16 & 38 & 26 & 62 \\
\hline & Any other & 75 & 6.2 & 14.05 & 5.35 & 26 & 35 & 49 & 65 \\
\hline \multirow{4}{*}{$\begin{array}{l}\text { Job } \\
\text { experience }\end{array}$} & $<5$ years & 388 & 32 & 15.03 & 5.39 & 88 & 22.7 & 300 & 77.3 \\
\hline & $5-10$ years & 433 & 35.7 & 14.7 & 5.53 & 136 & 31.4 & 297 & 68.6 \\
\hline & $11-15$ years & 234 & 19.3 & 13.55 & 5.18 & 85 & 36.3 & 149 & 63.7 \\
\hline & $>15$ years & 157 & 13 & 14.78 & 6.11 & 55 & 35 & 102 & 65 \\
\hline \multirow{4}{*}{ Position } & worker & 512 & 42.2 & 15.48 & 5.61 & 121 & 23.6 & 391 & 76.4 \\
\hline & supervisor & 445 & 36.7 & 13.22 & 5.27 & 180 & 40 & 265 & 60 \\
\hline & manager & 241 & 19.9 & 15.24 & 5.22 & 58 & 24 & 183 & 76 \\
\hline & executive & 14 & 1.2 & 14.57 & 6.61 & 5 & 35.7 & 9 & 64.3 \\
\hline \multirow{4}{*}{$\begin{array}{l}\text { Salary } \\
\text { (monthly) in } \\
\text { Pak Rupee }\end{array}$} & $<20 K$ & 585 & 48.3 & 15.07 & 5.71 & 156 & 26.7 & 429 & 73.3 \\
\hline & $20 \mathrm{~K}-50 \mathrm{~K}$ & 493 & 40.7 & 13.83 & 5.25 & 173 & 35 & 320 & 65 \\
\hline & $50 \mathrm{~K}-100 \mathrm{~K}$ & 116 & 9.6 & 15.74 & 5.33 & 29 & 25 & 87 & 75 \\
\hline & $<100 \mathrm{~K}$ & 18 & 1.5 & 12.5 & 4.27 & 6 & 50 & 12 & 50 \\
\hline \multirow{6}{*}{ Family size } & two or less & 95 & 7.8 & 15.77 & 5.73 & 24 & 25.3 & 71 & 74.7 \\
\hline & three & 133 & 11 & 14.19 & 5.83 & 47 & 35.3 & 86 & 64.7 \\
\hline & four & 329 & 27.1 & 13.68 & 5.31 & 115 & 35 & 214 & 65 \\
\hline & five & 323 & 26.7 & 14.38 & 5.41 & 105 & 32.5 & 218 & 67.5 \\
\hline & six & 155 & 12.8 & 15.53 & 5.08 & 28 & 18 & 127 & 82 \\
\hline & seven or more & 177 & 14.6 & 15.52 & 5.78 & 45 & 25.4 & 132 & 74.6 \\
\hline \multirow{5}{*}{$\begin{array}{l}\text { Educational } \\
\text { level }\end{array}$} & $<$ Matriculation & 175 & 14.4 & 16.51 & 5.5 & 38 & 21.7 & 137 & 78.3 \\
\hline & Matriculate & 361 & 29.8 & 14.22 & 5.57 & 113 & 31.3 & 248 & 68.7 \\
\hline & Intermediate/DAE & 322 & 26.6 & 13.98 & 5.33 & 112 & 34.8 & 210 & 65.2 \\
\hline & Graduate & 267 & 22 & 14.38 & 5.33 & 78 & 29.2 & 189 & 70.8 \\
\hline & Post graduate & 87 & 7.2 & 15.24 & 5.78 & 23 & 26.4 & 64 & 73.6 \\
\hline \multirow{2}{*}{$\begin{array}{l}\text { Size of the } \\
\text { organization }\end{array}$} & Large & 1053 & 86.9 & 14.2 & 5.54 & 340 & 33 & 688 & 67 \\
\hline & Small & 159 & 13.1 & 17.23 & 4.72 & 24 & 13 & 160 & 87 \\
\hline \multicolumn{2}{|l|}{ Overall } & 1212 & 100 & 14.59 & 5.52 & 364 & 30 & 848 & 70 \\
\hline
\end{tabular}

analysis, No Stress and Low Stress were summed together to correspond to Not Stressful while the scales: Moderate, High, and Severe were combined as Stressful. It is worrisome that only $364(30 \%)$ were in the Not Stressful group while a vast majority (around $70 \%$ of the sample population) was Stressful. Figure 3 shows that amongst the stressful subjects, a large group is in higher stress levels.
Role of demographics on the perceived stress

In order to ascertain the role of demographics on the individuals' perceived stress, independent sample t-tests and One-way ANOVA tests between subjects were deployed.

Independent sample t-test

Independent-sample t-tests were conducted to compare perceived stress score of male and female 


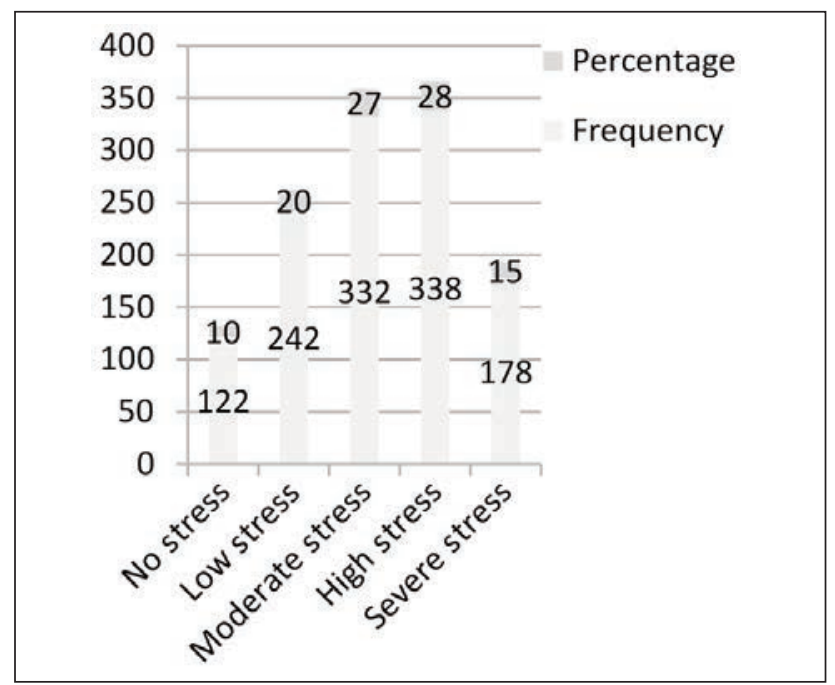

Fig. 1. Number and percentage of employees with respect to perceived stress levels $(\mathrm{N}=1212)$

employees, married and un-married employees, and employees of SMEs and employees of large organizations. There was a significant difference in the scores for male $(M=14.43, S D=5.43)$ and female $(M=15.70, S D=6.01)$ employees; $t(1210)=-2.65$, $p=0.008 ;$ married $(M=14.24, S D=5.43)$ and single $(M=15.49, S D=5.64)$ employees; $t(1200)=-3.41$, $p=0.001$; and SME employees $(M=17.00, S D=4.72)$ and large organization $(M=14.16, \quad S D=5.54)$ employees; $\mathrm{t}(1210)=-6.53, p=0.000$ (table 2). These results suggest that gender, marital status, and size of the organization do have an effect on the perceived stress levels of the employees. Specifically, results suggest that female employees, single employees, and SME employees are more stressful. This is in line with the Romanian textile and clothing industry where the implementation of performance management practices was found to be better in large organizations than SMEs [28].

\section{One-way ANOVA between subjects}

One-way ANOVAs between subjects were conducted to compare the role of employees' department, job experience, position, salary, family size, and educational level on their perceived stress levels. It revealed that working in different departments does not have a significant effect on the employees' perceived stress level $(E P S L)(p<0.05)[F(5,1206)=$ $0.955, p=0.444]$ whereas job experience significantly affects $(p<0.05)$ on EPSL $[F(3,1208)=3.71$,

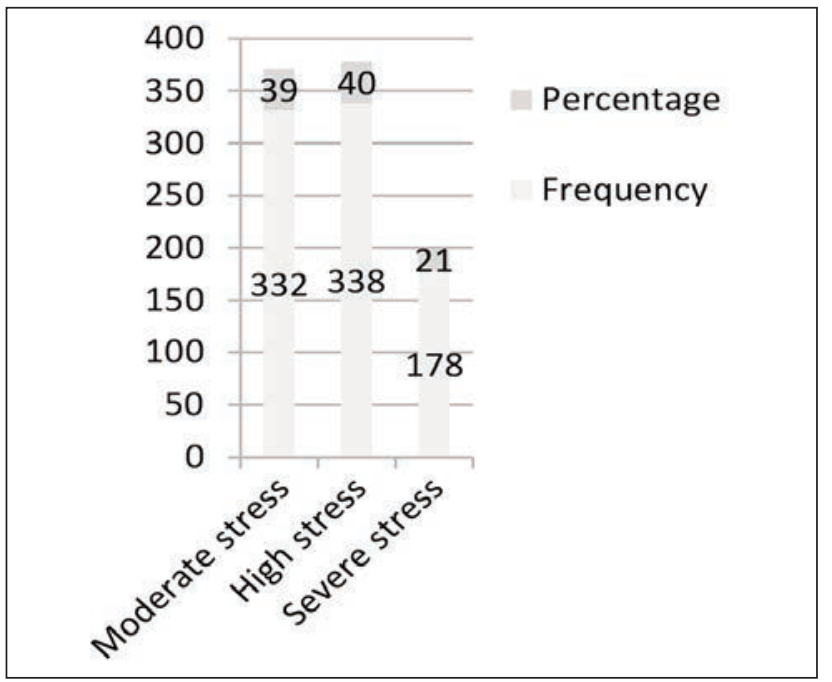

Fig. 2. Statistics of stressful employees $\mathrm{N}=848$

$p=0.011$ ]. Likewise, job experience was found to have an effect on EPSL. Specifically, the EPSL having job experience less than five years is more and results show that employees were more stressful at early stage of their careers. Ones' position in an organization is perceived as an important attribute as the study revealed that position significantly affects the EPSL $(p<0.05)[F(3,1208)=15.12, p=0.000]$, table 3 . The analysis revealed a significant effect $(p<0.05)$ of salary on $\operatorname{EPSL}[F(3,1208)=7.21, p=0.000]$. These results suggest that the salary of employee has an effect on EPSL. The EPSL in the lower salary category was higher.

Likewise, the effect of family size was found significant $(p<0.05)[F(5,1206)=4.89, p=0.000]$, table 3 . These results suggest that the family size of the employee has an effect on EPSL. Specifically, EPSL with family sizes, two or less, six and seven or more were higher. The educational level has a significant impact on perceived level of stress $(p<0.05)[F(4$, $1207)=7.26, p=0.000$ ], table 3 . Employees with lower educational level are more stressful.

In summary, the independent sample t-test and a one-way between subjects ANOVA results indicate that the demographics gender, marital status, job experience, monthly salary, position, family size, educational level and the employees' organization size significantly affect their perceived stress scores.

\begin{tabular}{|c|c|c|c|c|c|}
\hline \multicolumn{2}{|c|}{ INDEPENDENT SAMPLES TESTS: GENDER, MARITAL STATUS, ORGANIZATION SIZE } \\
\hline \multirow{2}{*}{ Variables } & \multicolumn{2}{|c|}{$\begin{array}{c}\text { Levene's test for equality } \\
\text { of variances }\end{array}$} & \multicolumn{3}{|c|}{ t-test for equality of means } \\
\cline { 2 - 6 } & $\mathrm{F}$ & Sig. & $\mathrm{t}$ & $\mathrm{df}$ & Sig. (2-tailed) \\
\hline Gender and PSS score & 2.94 & 0.087 & -2.655 & 1210 & 0.008 \\
\hline Marital status and PSS score & 0.084 & 0.772 & -3.412 & 1200 & 0.001 \\
\hline Organization size and PSS score & 5.555 & 0.019 & -6.528 & 1210 & 0 \\
\hline
\end{tabular}




\begin{tabular}{|c|c|c|c|c|c|c|}
\hline \multicolumn{7}{|c|}{ PSS SCORE - A ONE-WAY BETWEEN SUBJECTS ANOVA RESULTS } \\
\hline \multicolumn{2}{|c|}{ Demographics } & Sum of squares & df & Mean square & $\mathbf{F}$ & Sig. \\
\hline \multirow{2}{*}{ Department } & between groups & 145.512 & 5 & 29.102 & 0.955 & 0.444 \\
\hline & within groups & 36740.576 & 1206 & 30.465 & & \\
\hline \multirow{2}{*}{ Job experience } & between groups & 336.677 & 3 & 112.226 & 3.709 & 0.001 \\
\hline & within groups & 36549.411 & 1208 & 30.256 & & \\
\hline \multirow{2}{*}{ Position } & between groups & 1335.223 & 3 & 445.074 & 15.123 & 0.000 \\
\hline & within groups & 35550.865 & 1208 & 29.430 & & \\
\hline \multirow{2}{*}{ Salary (monthly) } & between groups & 648.671 & 3 & 216.224 & 7.208 & 0.000 \\
\hline & within groups & 36237.418 & 1208 & 29.998 & & \\
\hline \multirow{2}{*}{ Family size } & between groups & 733.102 & 5 & 146.620 & 4.891 & 0.000 \\
\hline & within groups & 36152.986 & 1206 & 29.978 & & \\
\hline \multirow{2}{*}{ Educational level } & between groups & 867.089 & 4 & 216.772 & 7.264 & 0.000 \\
\hline & within groups & 36018.999 & 1207 & 29.842 & & \\
\hline
\end{tabular}

\section{CONCLUSION}

The research aimed at investigating the perceived stress levels of the textile industry employees and how perceived stress is linked to different demographic variables. The study revealed that about $70 \%$ of participants were stressed at their jobs, though levels of their stress were different. The demographic factors gender, marital status, job experience, salary, educational level, family size, and the organization size have significant effects on the employees' perceived stress levels. However, the demographic variable department had no significant effect on stress. The situation demands implementation of effective interventions to protect the employees from unfavourable impacts of the stress which in turn will enhance the organizational performance. The findings of this work further highlight that work stress is a complex phenomenon which is influenced by a number of internal and external factors; so before devising some control or prevention strategies, it should be investigated appropriately so that effectiveness of the interventions might be enhanced. The findings of this study provide an opportunity to understand the complex nature of work stress phenomenon where the relationship of different demographic variables with the perceived stress have been studied in depth. Though the findings of this research are linked to the textile sector organizations; it provides a good insight about the complexity of stress phenomenon and can be linked with similar kind of working environments based on the nature of work. The results of the study have been detailed but as there has been no attempt to consider why things might be as they are, there is little in the way of guidance for those that want to use the results in the devising of prevention strategies. So, it would have been useful to have had an assessment of the likely causes of the difference between men and women so that these causes might be removed by the strategy.

\section{ACKNOWLEDGEMENT}

The study was supported by the UET, Lahore, Pakistan under grant Number ORIC/94-ASRB/138. Cooperation of industry in data collection is highly acknowledged.

\section{REFERENCES}

[1] Hoboubi, N., Choobineh, A., Kamari, F., The Impact of Job Stress and Job Satisfaction on Workforce Productivity in an Iranian Petrochemical Industry, In: Safety and Health at Work, 2017, 8, 1, 67-71

[2] Simion, C.-P., et al., Economic and IT determinants of innovative projects in the textiles, wearing apparel, leather and related products industry, In: Industria Textila, 2018, 69, 4, 338-344, http://doi.org/10.35530/IT.069.04.1478

[3] Ahmad, A., et al., Causes of Workplace Stress in Textile Industry of Developing Countries: A Case Study from Pakistan, In: Advances in Social \& Occupational Ergonomics, Advances in Intelligent Systems and Computing, Springer Orlando, Cham, 2017, 487, 283-294

[4] Ahmad, A., et al., Workplace Stress Assessment Among Managers of Textile Industries at Developing Countries: A Case Study from Pakistan, In: Advances in Human Factors, Business Management and Leadership, AHFE 2017, Springer, Cham, 2018, 594, 382-391

[5] Aftab, A., et al., Effects of Workplace Stress on Managers of Textile Industries of Developing Countries: A Case Study from Pakistan, In: Advances in Human Factors, Business Management and Society, AHFE 2018, Advances in Intelligent Systems and Computing, Springer, Cham, 2018, 783, 500-507

[6] Sharma, R., Singh, R., Work-related musculoskeletal disorders, job stressors and gender responses in foundry industry, In: International Journal of Occupational Safety and Ergonomics, 2014, 20, 2, 363-373 
[7] Tucker, M., Jimmieson, L., Nerina L., Oei, TP., The relevance of shared experiences: A multi-level study of collective efficacy as a moderator of job control in the stressor-strain relationship, In: Work \& Stress: An International Journal of Work, Health and Organizations,2013, 27, 1, 1-21

[8] Senaratne, S., Rasagopalasingam, V., The causes and effects of work stress in construction project managers: the case in Sri Lanka, In: International Journal of Construction Management, 2017, 17, 1, 65-75

[9] Adriaenssens, J., Veronique, D., Maes, S., Causes and consequences of occupational stress in emergency nurses, a longitudinal study, In:Journal of Nursing Management, 2015, 23, 3, 346-382

[10] Bridger, R., Day, A., Mortan, K., Occupational stress and employees turnover, In: Ergonomics, 2013, 56, 11, 1629-1639

[11] Choi, S., Lee, J., Park, H., The effects of Psychological problems in employees' stress, self esteem, and organizational committment: the case of South Korean workplaces, In: Journal of Workplace Behavioural Health, 2015, 30, 1, 2, 179-190

[12] Xavier, I., Jepsen, D., The Impact of Specific Job Stressors on Psychological Contract Breach and iolation, In: Human Factors and Ergonomics in Manufacturing \& Service Industries, 2015, 25, 5, 534-547

[13] Arnold, R., Fletcher, D., Daniels, K., Demographic differences in sport performers' experiences of organizational stressors, In: Scandinavian Journal of Medicine \& Science in Sports, 2016, 26, 3, 348-358

[14] Baron, R., et al., Why Entrepreneurs Often Experience Low, Not High, Levels of Stress: The Joint Effects of Selection and Psychological Capital, In: Journal of Management, 2016, 42, 3, 348-358

[15] Vieiraa, E., et al., Symptoms and risks for musculoskeletal disorders among male and female footwear industry workers, In: International Journal of Industrial Ergonomics, 2015, 48, 110-116

[16] Ashong, G., et al., Effects of occupational stress and coping mechanisms adopted by radiographers in Ghana, In: Radiography, 2015, 22, 2, 112-117

[17] Wiklund, M., et al., Subjective health complaints in older adolescents are related to per-ceived stress, anxiety and gender - A cross-sectional school study in Northern Sweden, In: BMC Public Health, 2012, 12, 993, 1471-2458

[18] Kitronza, P., Mairiaux, P., Stress among Textile Workers in the Democratic Republic of Congo, In: Tropical Medicine and Health, Occupational, 2015, 43, 4, 223-231

[19] Kizhakkeveettil, A., et al., Perceived stress and fatigue among students in a doctor of chiropractic training program, In: Journal of Chiropractic Education, 2017, 31, 8-13

[20] Pettit, M., DeBarr, K., Perceived Stress, Energy Drink Consumption, and Academic Performance Among College Students, In: Journal of American College Health, 2011, 59, 335-341

[21] Baka, Ł., Bazińska, R., Polish adaptation of three self-report measures of job stressors: the Interpersonal Conflict at Work Scale, the Quantitative Workload Inventory and the Organizational Constraints Scale, In: International Journal of Occupational Safety and Ergonomics, 2016, 22, 1, 32-39

[22] Steinisch, M., et al., Work stress: Its components and its association with self-reported health outcomes in a garment factory in Bangladesh - Findings from a cross-sectional study, In: Health \& Place, 2013, 24, 123-130

[23] Kanat, S., et al., SWOT analysis of Pakistan's textile and clothing industry, In: Industria Textila, 2018, 69, 502-510, http://doi.org/10.35530/IT.069.06.1488

[24] Cohen, S., Kamarck, T., Mermelstein, R., A global measure of perceived stress, In: Journal of Health and Social Behavior, 1983, 24, 4, 385-396

[25] Karkoulian, S., Srour, J., Sinan, T., A gender perspective on work-life balance, perceived stress, and locus of control, In: Journal of Business Research, 2016, 69, 11, 4918-4923

[26] Cohen, S., Janicki-Deverts, D., Miller, G., Psychological stress and disease, In: Journal of the American Medical Association, 2007, 298, 1685-1687

[27] Eby, L., et al., Are bad experiences stronger than good ones in mentoring relationships? Evidence from the protégé and mentor perspective, In: Journal of Vocational Behavior, 2010, 77, 81-92

[28] Girneata, A., et al., Performance management practices in Romanian textile and clothing companies, In: Industria Textila, 2015, 66, 108-113

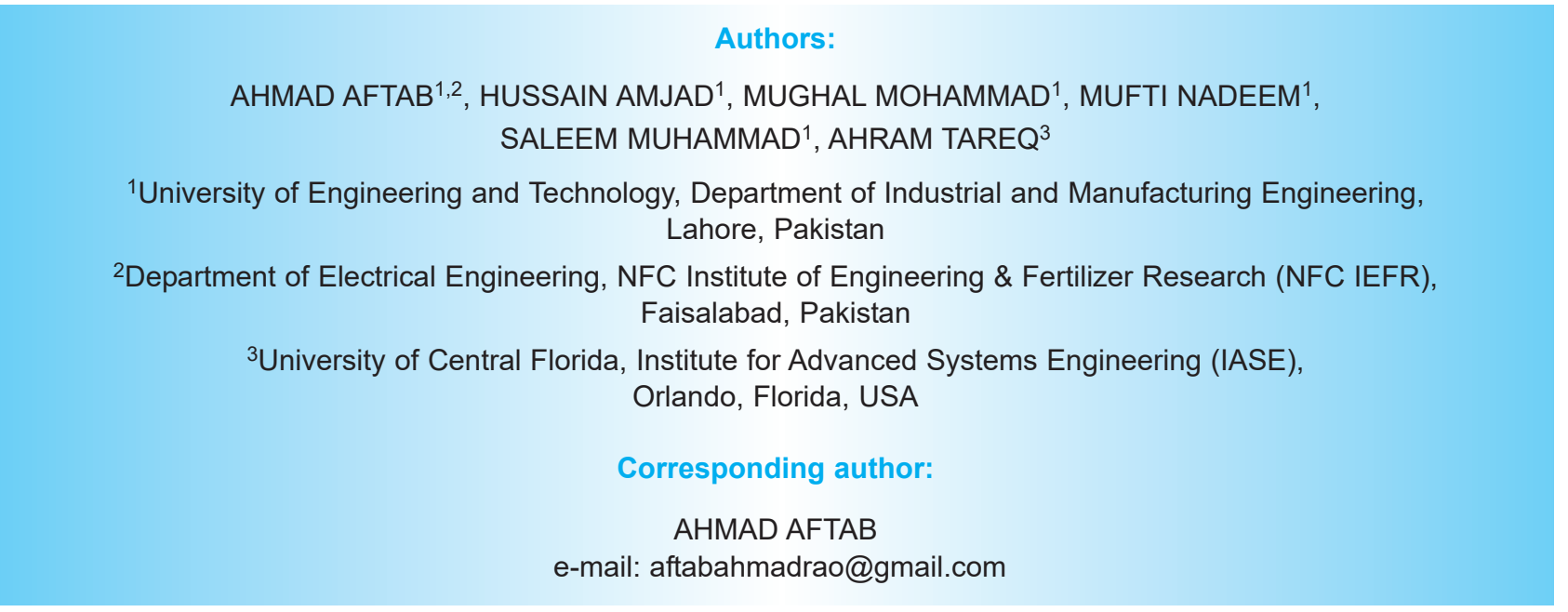




\title{
Functionalization of textile materials with bioactive polymeric systems based on propolis and cinnamon essential oil
}

\author{
DOI: 10.35530/IT.071.02.1793
}

LAURA CHIRILĂ

GABRIELA CRISTINA CONSTANTINESCU

ANGELA DANILA

ALINA POPESCU

ROXANA RODICA CONSTANTINESCU

IRINA-MARIANA SĂNDULACHE

\section{ABSTRACT - REZUMAT}

Functionalization of textile materials with bioactive polymeric systems based on propolis and cinnamon essential oil

In order to obtain the textile materials with potential for use in the treatment of inflammatory skin conditions, this study approached the laboratory experiments related to depositing by padding of oil-in-water emulsions type based on chitosan-propolis-cinnamon essential oil. In this regard, seven experimental variants of emulsions were prepared and then characterized by specific methods from physical-chemical and stability point of view. The chitosan-propoliscinnamon essential oil-based emulsions were then immobilized on a knitted textile structure from $100 \%$ organic cotton. The functionalized textile materials were characterized from morphological and antibacterial activity point of view. $\mathrm{pH}$ values obtained for the synthesized polymeric systems were in the range 4.67-4.88 and electrical conductivity of the emulsions increases with the concentration of the hydrophilic phase in the system, the highest values were registered for the emulsion code R4CSP developed with the smallest volume fraction of water. The stability index over a period of 10 days indicated that emulsions are stable, not showing the presence of one of the flocculation, creaming / sedimentation, coalescence or Ostwald ripening phenomena. The highest values of emulsifying activity index were obtained for the R7CSP, emulsion developed with the smallest volume fraction of water. The highest value of viscosity was obtained for the experimental variant R4CSP in which the highest volume fraction of chitosan and the smallest volume fraction of water were used. The textile materials treated with synthesized emulsions based on chitosanpropolis-cinnamon essential oil have antibacterial effect against the $S$. aureus test strain, with inhibition zones between $1.5 \mathrm{~mm}$ (R2CSP and R7CSP) and $4 \mathrm{~mm}$ (R6CSP).

Keywords: functionalized textiles, bioactive compounds, chitosan, cinnamon essential oil, propolis

\section{Funcționalizarea materialelor textile cu sisteme polimerice bioactive pe bază de propolis și ulei esențial} de scorțișoară

Pentru a obține materiale textile cu potențial de utilizare în tratamentul afecțiunilor inflamatorii ale pielii, acest studiu a abordat experimentări de laborator cu privire la depunerea prin metoda fulardării a emulsiilor de tipul ulei-în-apă, pe bază de chitosan-propolis-ulei esențial de scorțișoară. În acest sens, au fost preparate șapte variante experimentale de emulsii și apoi caracterizate prin metode specifice din punct de vedere fizico-chimic și al stabilității. Emulsiile pe bază de chitosan-propolis-ulei esențial de scorțișoară au fost apoi imobilizate pe o structură textilă tricotată din $100 \%$ bumbac organic. Materialele textile funcționalizate au fost caracterizate din punct de vedere morfologic și al activității antibacteriene. $\mathrm{pH}-\mathrm{ul}$ sistemelor bioactive este cuprins între 4,67 si 4,88; conductivitatea electrică crește odată cu concentrația fazei hidrofile, cele mai mari valori înregistrându-se pentru proba cod R4CSP, care conține cea mai mică fracție volumică de apă. Indicele de stabilitate analizat pe o durată de 10 zile a indicat faptul că emulsiile sunt stabile, neindicând prezența unuia dintre fenomenele de floculare, cremare/sedimentare, coalescență sau maturare Ostwald. Valorile cele mai mari ale indicelui activității emulgatoare au fost obținute pentru R7CSP, emulsia realizată cu cea mai mică fracție volumică de apă. Cea mai mare valoare a viscozității a fost obținută pentru varianta experimentală $R 4 C S P$, în care a fost utilizată cea mai mare fracție volumică de chitosan și cea mai mică fracție volumică de apă. Materialele textile tratate cu emulsiile sintetizate pe bază de chitosan-propolis-ulei esențial de scorțișoară prezintă efect antibacterian împotriva tulpinii test S. aureus, cu zone de inhibiție cuprinse între 1,5 mm (R2CSP și R7CSP) și $4 \mathrm{~mm}$ (R6CSP).

Cuvinte-cheie: textile funcționalizate, compuși bioactivi, chitosan, ulei esențial de scorțișoară, propolis

\section{INTRODUCTION}

The development of multifunctional textile materials based on nano- and micro-technologies represents one of the most competitive and dynamic areas of research worldwide, being a major factor in the sustainable development of the textile industry [1]. The design of biopolymeric matrices for the delivery of bioactive compounds constitutes a science-based strategy to provide textile materials with the multifunctional properties [2-3]. Natural compounds derivatives from plants can demonstrate various biological effects, including antibacterial and antifungal activity, anti-inflammatory and antioxidant effects [4]. 
Essential oils have gained new interest in several areas of interest. As natural products they have physico-chemical characteristics that are friendly to the environment with added value. It also possesses a relevant biological activity, being used in the medical field thanks to their biocidal activity (bactericides, virucides and fungicides) and medicinal properties.

Cinnamon (Cinnamomum zeylanicum) essential oil has been widely applied in food products-and it benefits health in various ways due to its antioxidant and antimicrobial properties [5-6]. Furthermore, cinnamon essential oil has gained popularity for use in skin care products, research on its effects on human skin is largely scarce. The major active components of cinnamon essential oil taken from the bark are cinnamaldehyde, eugenol, carvacrol and linalool. A study [7] conducted on human keratinocytes demonstrated the antioxidant effect of cinnamaldehyde, as well as its potential for treating skin disorders. Using essential oils as bioactive compounds is limited due to their low solubility, instability against environmental conditions and susceptibility to oxidative degradation, resulting in the loss of the functional properties [8-9]. Embedding the biologically active components into polymeric matrices is a procedure studied over the last decades worldwide and can provide an ideal solution for achieving a controlled and targeted delivery of the essential oil [10-11]. The polymer is used as protective carrier for the bioactive compound during the transfer until it is released.

Propolis, a natural resinous product, is widely known by its high composition of bioactive compounds and largely used in folk medicine. Propolis has diverse biological activities: it shows antibacterial, antiinflammatory, free radical scavenging, antioxidant, and antitumor effects. The wealth of its bioactive components determines its application in medicine and dentistry as well as in the pharmaceutical, cosmetics, and food industries. Previous studies have shown that propolis is effective in healing wounds and various skin injuries. Propolis is used in the local treatment of burns as an antibacterial, deodorant, anesthetic and stimulant of the regenerative process, forming on the surface of wounds or scars a protective layer, which protects the wound and allows the healing process to begin from its depth.

The aim of the study was to develop textile materials with functional properties by applying bioactive polymeric systems based on chitosan-propolis-cinnamon essential oil. For this purpose, the formulations experiments of bioactive polymeric systems - oil-in-water (O/W) type emulsions have been carried out. The aim was to identify the main factors influencing the formulation process and the stability of the new developed emulsions.

\section{EXPERIMENTAL PART}

\section{Materials}

Chitosan with low molecular weight, $85 \%$ deacetylation degree (Fluka Chemie $\mathrm{GmbH}$, Switzerland) was used as an embedding agent of bioactive agents. Chitosan flakes were dissolved in solution of $\mathrm{CH}_{3} \mathrm{COOH}$ (96\%) (Consors, Romania). Tween 80 (Sigma Aldrich, Germany) was used as a surfactant with emulsifying role and glycerol (Honeywell, USA) has been used as a solubilizing with wetting role. Cinnamon leaf essential oil (Mayam, Romania) and propolis tincture (Larix SA, Romania) $70 \%$ ethanol solution were used as bioactive agents. For preparation of bioactive systems, the distilled water has been used. Bleached $100 \%$ knitted organic cotton was used for the functionalization processes.

\section{Emulsion preparation methodology}

For the achievement of the bioactive systems, initially stock solutions of $3 \%$ chitosan in $2 \% \mathrm{CH}_{3} \mathrm{COOH}$ and $30 \%$ Tween 80 solution were prepared. Further, over the previously prepared chitosan solution, distilled water was added dropwise, under continuous stirring until a homogeneous mixture was obtained. Glycerol was added to the chitosan/water system, and the system was maintained under magnetic stirring for 10 minutes, after which Tween 80 emulsifier was added. After complete homogenization of the solution, the propolis and cinnamon essential oil were separately added, maintaining the magnetic stirring for 10 minutes for each stage.

The stages of obtaining emulsions based on chitosan-propolis-cinnamon essential oil are shown in figure 1.



Fig. 1. The stages of obtaining emulsions based on chitosan-propolis-cinnamon essential oil

Thus, 7 variants of emulsions have been developed that differ by: i) the concentration of the embedding agent (chitosan), ii) the concentration of the selected bioactive compounds. For all experimental variants, the ratio between the two selected bioactive compounds was kept constant. The selected experimental variants are presented in table 1.

\section{Immobilization of bioactive polymeric systems on the textile materials}

The 7 experimental variants were immobilized on the textile materials by the padding method on the laboratory padder (ROACHES, UK). The treated textile materials were then subjected to the drying operation at $50^{\circ} \mathrm{C}$ for 3 minutes. Subsequently, the textile materials were analysed from morphological and antibacterial activity point of view. 

activity: The antibacterial COMPOSITION OF THE EMULSIONS (REPORTED OF 30 ML EMULSION)

\begin{tabular}{|c|c|c|c|c|c|c|}
\hline Code & $\begin{array}{c}\text { Chitosan } \\
(\mathbf{m l})\end{array}$ & $\begin{array}{c}\text { Tween } \mathbf{8 0} \\
(\mathbf{m l})\end{array}$ & $\begin{array}{c}\text { Glycerol } \\
(\mathbf{m l})\end{array}$ & $\begin{array}{c}\text { Distilled } \\
\text { water }(\mathbf{m l})\end{array}$ & $\begin{array}{c}\text { Essential } \\
\text { oil }(\mathbf{m l})\end{array}$ & $\begin{array}{c}\text { Propolis } \\
(\mathbf{m l})\end{array}$ \\
\hline R1CSP & 9 & 0.5 & 2.7 & 16 & 0.9 & 0.9 \\
\hline R2CSP & 12 & 0.5 & 2.7 & 13.0 & 0.9 & 0.9 \\
\hline R3CSP & 15 & 0.5 & 2.7 & 10.0 & 0.9 & 0.9 \\
\hline R4CSP & 18 & 0.5 & 2.7 & 7.0 & 0.9 & 0.9 \\
\hline R5CSP & 15 & 0.5 & 2.7 & 11.2 & 0.3 & 0.3 \\
\hline R6CSP & 15 & 0.5 & 2.7 & 10.6 & 0.6 & 0.6 \\
\hline R7CSP & 15 & 0.5 & 2.7 & 9.4 & 1.2 & 1.2 \\
\hline
\end{tabular}
activity of the treated samples in different variants was qualitatively assessed by Agar diffusion method according with the SR EN ISO 20645:2005 standard - Determination of antibacterial activity-agar diffusion plate test, by using of cultures in liquid medium replicated at 24 hours of ATCC 6538 Staphylococcus aureus test strains (Gram-

\section{Methods}

Optical microscopy: The emulsions prepared according to the working recipes were analysed microscopically using an OLYMPUS BX51 optical microscope (Philippines) equipped with the OLYMPUS UC30 photo digital camera.

$\mathrm{pH}$ determination: Emulsion $\mathrm{pH}$ was directly measured using a HANNA portable $\mathrm{pH}$-meter immersed in the prepared undiluted emulsions. The measurements were performed in triplicate.

Conductometric analysis: The conductivity of the analyzed emulsions was measured directly, using the Consort conductometer, model C1020 WTW (TARA), with SP10T electrode. The conductivity values represent the average of 3 successive readings made on the same sample.

Determination of the emulsion stability index: The stability of an emulsion can be appreciated immediately after preparation and/or after a certain period of time. Immediately after preparation, the emulsions were introduced into test tubes and the evolution was followed for 10 days after their preparation. The stability of the emulsions was evaluated by determining the stability index (ESI) using the equation (1):

$$
E S I(\%)=[H-(H s+H c)] / H
$$

where $H$ is the initial height of the emulsion $(\mathrm{cm})$, $\mathrm{Hs}$ - the height of the serous layer $(\mathrm{cm}), \mathrm{Hc}$ - the height of the creamy layer (cm).

Turbidity analysis: In order to determine the turbidity, the transmittance was determined, using a Camspec M501 UV-VIS Spectrophotometer. Turbidity was calculated with the equation (2):

$$
\tau=2.303 \cdot A / L
$$

where $\tau$ is turbidity $\left(\mathrm{cm}^{-1}\right), A-$ absorbance, $L-$ path length of cuvette $(\mathrm{cm})$.

Viscosity determination: The viscosity measurements of the obtained bioactive systems were performed with the DV2T Brookfield AMETEK viscometer. Measurements were performed in triplicate.

Electron microscopy: Visualization of the morphology of the cotton fiber surfaces treated with the bioactive systems was performed by scanning electron microscopy using the Quanta 200 electron microscope (FEl, The Netherlands). positive) and ATCC 11229 Escherichia coli (Gramnegative) test strains. Firstly, the Manitol Salt Agar gel for Staphylococcus aureus and Nutrient Agar gel for Escherichia coli were prepared for the lower layer without bacteria. Thus, $10 \pm 0.1 \mathrm{ml}$ gel was placed into each sterilized Petri dish and allow gel to solidify. Another amount of gel was prepared for the upper layer and cooled to $45^{\circ} \mathrm{C}$ in a water bath. $150 \mathrm{ml}$ of gel is inoculated with $1 \mathrm{ml}$ of bacterial working solution $1-5 \times 10^{8} / \mathrm{ml}$. The container is vigorously stirred for the uniform distribution of bacteria. The quantity of $5 \pm 0.1 \mathrm{ml}$ are introduced in each Petri plates and allow the gel to solidify. The textile specimens $(2 \mathrm{~cm}$ diameter) are placed on the surface of the nutrient medium and then incubated at $37^{\circ} \mathrm{C}$ for $24 \mathrm{~h}$. The antibacterial evaluation was based on the absence or presence of bacterial multiplication in the contact area between the agar and the test specimen and on the occurrence of a possible inhibition area around the specimens. Inhibition zones were calculated using the following equation (3):

$$
H=(D-d) / 2
$$

where $H$ is the inhibition zone $(\mathrm{mm}), D$ - the total diameter of specimen and inhibition zone $(\mathrm{mm}), d-$ the diameter of specimen $(\mathrm{mm})$.

The evaluation of the results obtained after the calculation of the inhibition zones was performed according to the criteria from SR EN ISO 20645:2005 standard, depicted in the table 2.

\begin{tabular}{|c|c|}
\hline \multicolumn{2}{|c|}{ Table 2} \\
\hline \multicolumn{3}{|c|}{ PCRITERIA FOR EVALUATION OF INHIBITION ZONES } \\
ACCORDING TO THE \\
\begin{tabular}{|c|c|c|}
\hline $\begin{array}{c}\text { Inhibition zone } \\
(\mathbf{m m})\end{array}$ & Growth & Evaluation \\
\hline$>1$ & $\begin{array}{l}\text { absent } \\
\text { absent } \\
\text { absent } \\
0\end{array}$ & Satisfactory effect \\
\hline 0 & low & Efficiency limit \\
\hline 0 & $\begin{array}{l}\text { moderate } \\
\text { important }\end{array}$ & Unsatisfactory effect \\
\hline 0
\end{tabular}
\end{tabular}




\section{RESULTS AND DISCUSSION}

\section{Emulsions appearance}

From the visual analysis it is observed that, the emulsions prepared are presented in the form of homogeneous white-yellow-milky solutions without particle agglomerations throughout the sample mass. The images obtained by optical microscopy for the 7 experimental variants are shown in figure 2 . According to microscopic images, the dispersed molecule phase is presented as a compact, dense small globule mass. Normally, the destabilization of the emulsions begins with the drops flocculation of essential oil followed by the phenomenon of coalescence and formation of two distinct phases (separation).



Fig. 2. Optical microscopy of the resulted bioactive systems

\section{Physical-chemical analysis of emulsions}

The $\mathrm{pH}$ and conductivity values recorded for the synthesized polymeric systems are presented in table 3 . Analyzing comparatively the $\mathrm{pH}$ values obtained for the synthesized polymeric systems (table 3 ) it can be seen that they are in the range 4.67-4.88. It can also be observed that the addition of a higher quantity of active principle (essential oil and propolis) causes a lower acid $\mathrm{pH}$. The electrical conductivity of the emulsions increases with the concentration of the hydrophilic phase in the system, highest values registered the for the emulsion developed with the smallest volume fraction of water (e.g. R4CSP). There is no linear dependence between the values of conductivity and the volume fraction of essential oil.

\section{Emulsions stability}

The calculated values for the stability index, are shown in table 4 . The values recorded for the stability index over a period of 10 days indicate that they were stable, during this time not showing the presence of one of the flocculation, creaming/sedimentation, coalescence or Ostwald ripening phenomena. Generally, the turbidity of the bioactive polymeric systems is correlated to a great extent with their stability. Analysing the values obtained for the 7 experimental variants (table 4) it can be observed that the lowest values of the turbidity were obtained for the R5CSP variant (1.81) in which the smallest amount of active principle is also present (essential oil and propolis). Turbidity decreases with increasing particle size of emulsion.

\section{UV-VIS analysis}

The UV-VIS spectra recorded for the obtained polymeric systems are shown in figure 3 . UV-vis spectra revealed the presence of absorption bands in the 220-290 nm UV range. The analysed emulsions are characterized by intense absorption in the 270-290 $\mathrm{nm}$ area. The major peak in this area is very close to the maximum absorption (286 $\mathrm{nm}$ ) obtained for cinnamaldehyde, the majority compound present in the cinnamon essential oil [12].

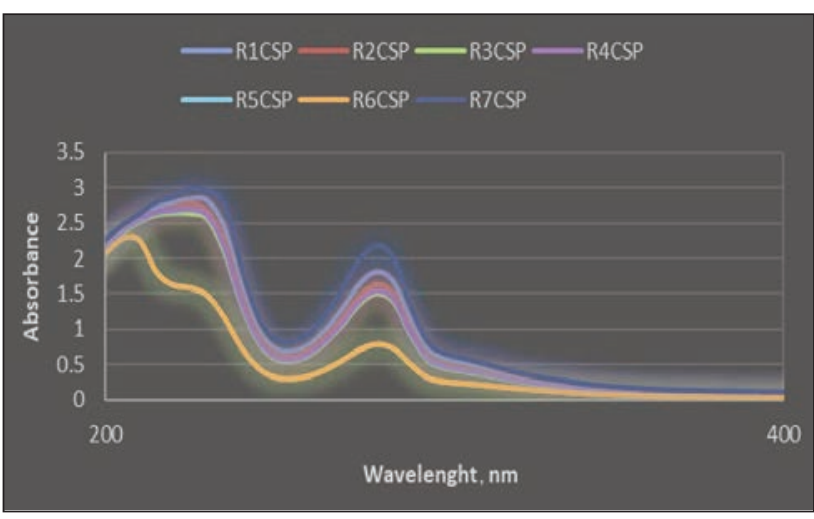

Fig. 3. UV-VIS spectra recorded for the chitosanpropolis-cinnamon essential oil systems

\begin{tabular}{|c|c|c|c|c|c|c|c|}
\hline \multicolumn{8}{|c|}{ CONDUCTIVITY AND pH OF BIOACTIVE SYSTEMS } \\
\hline \multirow{2}{*}{ Parameters measured } & \multicolumn{7}{|c|}{ Code } \\
\hline & R1CSP & R2CSP & R3CSP & R4CSP & R5CSP & R6CSP & R7CSP \\
\hline $\mathrm{pH}$ & 4.67 & 4.68 & 4.67 & 4.83 & 4.84 & 4.86 & 4.88 \\
\hline Conductivity $(\mathrm{m} \cdot \mathrm{S} / \mathrm{cm})$ & 1.24 & 1.54 & 1.84 & 2.20 & 2.01 & 1.99 & 1.78 \\
\hline
\end{tabular}

\begin{tabular}{|c|c|c|c|c|c|c|c|}
\hline \multicolumn{1}{|c|}{ STABILITY OF EMULSIONS } \\
\hline Stability & R1CSP & R2CSP & R3CSP & R4CSP & R5CSP & R6CSP & R7CSP \\
\hline Turbidity $\left(\mathrm{cm}^{-1}\right)$ & 4.184 & 3.762 & 3.484 & 3.562 & 1.816 & 1.956 & 5.024 \\
\hline Stability index $(\%)$ & 100 & 100 & 100 & 100 & 100 & 100 & 100 \\
\hline
\end{tabular}


The main viscosity indices recorded for the synthesized emulsions are shown in table 5 .

From the comparative analysis of the viscosities values it is observed that the highest value was obtained for the experimental variant R4CSP $(237.5 \mathrm{cP})$ in which the highest volume fraction of chitosan and the smallest volume fraction of water (R4CSP) were used. It can also be observed that the viscosity of the system is not dependent on the volume fraction of active principle (propolis and essential oil), the highest amount of active principle in the system

\begin{tabular}{|c|c|c|c|c|c|}
\hline \multicolumn{2}{|c|}{ VISCOSITY INDICES RECORDED FOR THE EMULSIONS } \\
\hline Code & $\begin{array}{c}\text { Viscosity } \\
\text { (cP) }\end{array}$ & $\begin{array}{c}\text { SS } \\
\left(\text { dyne/cm }^{2}\right)\end{array}$ & $\begin{array}{c}\text { SR } \\
\left(\mathbf{s}^{-1}\right)\end{array}$ & $\begin{array}{c}\text { Speed } \\
\text { (RPM) }\end{array}$ & $\begin{array}{c}\text { Temperature } \\
\left({ }^{\circ} \text { C) }\right.\end{array}$ \\
\hline R1CSP & 57.16 & 106.36 & 186 & 200 & 25.33 \\
\hline R2CSP & 95.16 & 177.03 & 186 & 200 & 25.33 \\
\hline R3CSP & 151.13 & 281.03 & 186 & 200 & 25.4 \\
\hline R4CSP & 237.5 & 441.8 & 186 & 200 & 25.3 \\
\hline R5CSP & 133.1 & 247.53 & 186 & 200 & 25.43 \\
\hline R6CSP & 147.86 & 274.96 & 186 & 200 & 25.53 \\
\hline R7CSP & 126.2 & 243.7 & 186 & 200 & 25.76 \\
\hline
\end{tabular}
(R7CSP, $\varphi=0.08 \mathrm{ml}$ active principle $/ \mathrm{ml}$ emulsion) leading to obtaining of a viscosity with comparable values to those obtained when using smaller volume fractions $(\varphi=0.06 \mathrm{ml}$ oil $/ \mathrm{mL}$ emulsion, $\varphi=0.04 \mathrm{ml}$ oil $/ \mathrm{mL}$ emulsion). The shear stress (SS) has the highest value in the case of the R4CSP variant, the variant obtained when using the largest volume fraction of chitosan, respectively the smallest volume fraction of water.

\section{Electron microscopy of textile materials functionalized with bioactive systems}

The images obtained at a magnification of $\times 8000$ for knitted textiles treated with bioactive systems are shown in figure 4 . The resulting micrographs reveal that the surface of the cotton fibers is covered with a thin polymeric layer deposited both on the surface of the fibers and inside the space between the fibers. However, the micrographs cannot provide information about the thickness of the deposited layer and its uniformity.

\section{Assessment of antibacterial activity}

Images of Petri plates after $24 \mathrm{~h}$ incubation are shown in figure 5 and assessment of antibacterial activity is shown in table 6.



Fig. 4. Electronic images recorded for the knitted fabrics treated with chitosan-propolis-cinnamon essential oil polymeric system

By analyzing the obtained results it can be concluded that the textile materials treated with synthesized emulsions based on chitosan-propolis-cinnamon essential oil have antibacterial effect against the $S$. aureus test strain, with inhibition zones between $1.5 \mathrm{~mm}$ (R2CSP and R7CSP) and $4 \mathrm{~mm}$ (R6CSP). In the case of $E$. coli strain, the presence of the inhibition zone and the growth of the test strain in the whole culture medium were not observed, being considered a satisfactory effect in terms of antibacterial activity. There is no correlation between the amount of active principle and the obtained antibacterial effect, the sample treated with the emulsion with the

\begin{tabular}{|c|c|c|c|c|}
\hline \multicolumn{4}{|c|}{ EVALUATION OF THE ANTIBACTERIAL ACTIVITY } \\
\hline \multirow{2}{*}{ Code } & \multicolumn{2}{|c|}{ E. coli } & \multicolumn{2}{c|}{ S. aureus } \\
\cline { 2 - 5 } & Inhibition zone (mm) & Evaluation & Inhibition zone $(\mathbf{m m})$ & Evaluation \\
\hline R1CSP & $-\left(^{*}\right)$ & Satisfactory effect & $-\left(^{*}\right)$ & Satisfactory effect \\
\hline R2CSP & $-\left(^{*}\right)$ & Satisfactory effect & 1.5 & Satisfactory effect \\
\hline R3CSP & $-\left(^{*}\right)$ & Satisfactory effect & $-\left(^{*}\right)$ & Satisfactory effect \\
\hline R4CSP & $-\left(^{*}\right)$ & Satisfactory effect & 2.5 & Satisfactory effect \\
\hline R5CSP & $-\left(^{*}\right)$ & Satisfactory effect & 3 & Satisfactory effect \\
\hline R6CSP & $-\left(^{*}\right)$ & Satisfactory effect & 4 & Satisfactory effect \\
\hline R7CSP & $-\left(^{*}\right)$ & Satisfactory effect & 1.5 & Unsatisfactory effect \\
\hline M & $-\left(^{*}\right)$ & Unsatisfactory effect & $-\left(^{*}\right)$ & \\
\hline
\end{tabular}

$\left(^{*}\right)$ No inhibition zone, no multiplication. 




Fig. 5. Images of Petri plates showing antibacterial effect after $24 \mathrm{~h}$ of incubation

highest amount of active principle (R7CSP) having the smallest zone of inhibition $(1.5 \mathrm{~mm})$.

\section{CONCLUSIONS}

Seven exprimental variants of bioactive polymer systems synthesized based on chitosan-propolis-cinamon essential oil were assessed to explore their physico-chemical, biological as well as functional property to understand the possible applications in developing biomedical textiles. From the corroboration of the obtained data it was found that the obtained emulsions have a high degree of stability and a suitable viscosity to ensure a uniform deposition on the textile materials, on the one hand, and on the other hand to be able to be kept in a single phase until further application on textile materials. Textile materials treated with bioactive polymeric systems have shown antibacterial activity for both gram positive bacteria ( $S$. aureus) and gram negative bacteria (E. coli) test strains. The research on the potential bioactive polymeric systems based on chitosanpropolis-cinnamon for multifunctional properties development on textile materials is in progress.

\section{ACKNOWLEDGMENTS}

This work was carried out through the Nucleu Programme, with the support of MEC, project no. 4N/08.02.2019, PN 19 1703 01, project title: "Multifunctional integrated systems based on nanocomposites and pharmacodynamic therapeutic agents for different skin conditions - BIOPANTEX".

\section{REFERENCES}

[1] Subtirica, A.I., Banciu, C.A., Chivu, A.A.-M., Dinca, L.C., Nanofibres made from biocompatible and biodegradable polymers, with potential application as medical textiles, In: Industria Textila, 2018, 69, 1, 55-58, http://doi.org/ 10.35530/IT.069.01.1502

[2] Šauperl, O., Fras Zemljič, L., Volmajer Valh, J., Tompa, J., Textile cosmetic pads based on psyllium and protein colloid in combination with the horsetail extract, In: Industria Textila, 2019, 70, 1, 21-24, http://doi.org/ 10.35530/IT.070.01.1479

[3] Adomavičiūtè, E., Baltušnikaitè-Guzaitienè J., Juškaitè V., Žilius M., Briedisb V., Stanys, S., Formation and characterization of melt-spun polypropylene fibers with propolis for medical applications, In: The Journal of The Textile Institute, 2017, 109, 2, 278-284

[4] Najee, H., Kamerzan, C., Marutescu, L., Gheorghe. I., Popa, M., Grădișteanu, G., Lazăr, V., Antifungal activity of some medicinal plant extracts against Candida albicans nosocomial isolates, In: Romanian Biotechnological Letters, 2018, 23, 6, 14073-14076

[5] Shahid, M.Z., Saima, H., Yasmin, A., Nadeem, M.T., Imran, M., Afzaal, M., Antioxidant capacity of cinnamon extract for palm oil stability, In: Lipids in Health and Disease, 2018, 17, 116, https://doi.org/10.1186/s12944-018-0756-y

[6] Sharifan, A., Shafiee, M., Tabatabaee, A., Evaluation of antimicrobial effect of Cinnamomum verum methanolic extract and essential oil: a study on bio-preservative in ketchup sauce, In: J. Chem. Health Risks, 2016, 6, 2, 113-124

[7] Uchi, H., Yasumatsu, M., Morino-Koga, S., Mitoma C., Furue, M., Inhibition of aryl hydrocarbon receptor signaling and induction of NRF2-mediated antioxidant activity by cinnamaldehyde in human keratinocytes, In: J Dermatol Sci, $2017,85,1,36-43$

[8] Chuesiang, P., Siripatrawan U., Sanguandeekul, R., Yang, J.S., McClements, D.J., McLandsborough, L., Antimicrobial activity and chemical stability of cinnamon oil in oil-in-water nanoemulsions fabricated using the phase inversion temperature method, In: LWT - Food Science and Technology, 2019, 110, 190-196

[9] Cui, H., Li W., Li, C., Vittayapadung, S., Lin, L., Liposome containing cinnamon oil with antibacterial activity against methicillin-resistant Staphylococcus aureus biofilm, In: Biofouling, 2016, 32, 215-225 
[10] Fu, X.R., Shen, I., Jiang, X., Huang, D., Yan Y., Chitosan derivatives with dual-antibacterial functional groups for antimicrobial finishing of cotton fabrics, In: Carbohydrate Polymers, 2011, 85, 1, 221-227

[11] Bansal, V., Sharma, P.K., Sharma, N., Pal, P.O., Malviya R., Application of chitosan and chitosan derivatives in drug delivery, In: Advances in Biological Research, 2011, 5, 1, 28-37

[12] Rind, F.M.A., Memon, A.H., Almani, F., Laghari, M.G.H., Mughal, U.R., Maheshwari, M.L., Khuhawar, M.Y., Spectrophotometric determination of cinnamaldehyde from crude drugs and herbal preparations, In: Asian Journal of Chemistry, 2011, 23, 2, 631-635

Authors:

LAURA CHIRILĂ ${ }^{1}$, GABRIELA CRISTINA CONSTANTINESCU ${ }^{1}$, ANGELA DANILA², ALINA POPESCU ${ }^{1}$, ROXANA RODICA CONSTANTINESCU ${ }^{3}$, IRINA-MARIANA SĂNDULACHE ${ }^{1}$

${ }^{1}$ National Research and Development Institute for Textiles and Leather, 16 Lucretiu Patrascanu Street, 030508, Bucharest, Romania e-mail: office@incdtp.ro

2“Gheorghe Asachi” Technical University of lasi, Faculty of Industrial Design and Business Management, 29 Prof. Dr. Doc. Dimitrie Mangeron Blvd., 700050, lasi, Romania

${ }^{3}$ National Research and Development Institute for Textiles and Leather, Leather and Footwear Research Institute (ICPI) Division, 93, Ion Minulescu Street, 031215, Bucharest, Romania

Corresponding author:

ANGELA DANILA

e-mail: acerempei@tuiasi.ro 


\title{
Romania's participation in FP7 and H2020: a comparative approach in the context of the new EU member countries
}

\author{
DOI: $10.35530 / I T .071 .02 .1813$
}

Romania's participation in FP7 and H2020: a comparative approach in the context of the new EU member countries

The main objective of the paper is to provide a general overview on Romania's ability to attract European funds for research, development and innovation. The paper compares the participation of the former communist countries of Europe in FP7 and H2020. The main conclusions of the analysis are: EU12 presents cumulative participation in the research framework programs far below Western Europe; the productivity of EU12 research staff, measured by the ability to attract European funds, has increased significantly, but there are large gaps between the countries analysed; Romania has seen an improvement in the participation in the two European programs, but remains on the last place in terms of EU contribution per inhabitant.

Keywords: EU funding, H2020, FP7, EU12, Romania

\section{Participarea României la FP7 şi H2020: analiză comparativă în contextul noilor ţări membre UE}

Principalul obiectiv al lucrării este să ofere o perspectivă generală asupra capacităţii României de a atrage fonduri europene pentru cercetare, dezvoltare şi inovare. Lucrarea analizează comparativ participarea ţărilor foste comuniste din Europa la FP7 şi H2020. Principalele concluzii ale analizei sunt: EU12 prezintă cumulat o participare la programele cadru de cercetare mult inferioară Europei de Vest; productivitatea personalului din domeniul cercetării din EU12, măsurată prin capacitatea de a atrage fonduri europene, a crescut semnificativ, dar există decalaje mari între ţările analizate; România a cunoscut o îmbunătătire a participării la cele două programe europene, dar rămâne pe ultimul loc din punctul de vedere al contribuţiei Uniunii Europene pe locuitor.

Cuvinte-cheie: finanțare UE, H2020, FP7, EU12, România

\section{INTRODUCTION}

The main objective of this paper is to present a general view of the Romanian scientific community interest into use the European funds designated for research, development and innovation actions in a regional context. Horizon 2020, the European Union's 8th Framework Programme for Research, is the financial instrument implementing the Innovation Union. It is the programme that has a budget of almost $€ 80$ billion for the seven years of the programme (2014-2020), it is the largest budget from all the Framework programmes.

Horizon 2020 is built on three pillars:

1. Support for Excellent Science: frontier research funded by the European Research Council; networking of existing research infrastructures; mobility grants for all stages of researchers' careers (Marie Skłodowska-Curie actions).

2. Support for Industrial Leadership: projects of great importance for Europe's industrial competitiveness; targeted support of small and medium enterprises (SMEs).
3. Support for research to tackle societal challenges: projects focusing on the priority societal challenges identified by the EU.

In addition, there are four further cross-cutting and supporting measures:

- Spreading Excellence and Widening Participation.

- Science with and for Society.

- Joint Research Centre (JRC).

- European Institute of Innovation and Technology (EIT).

FP 7 was the main instrument of European Union for research funding in Europe during 2007-2013, with a total budget of 53.2 billion euro. It was structured in five components: Cooperation, Ideas, People, Capacities and Nuclear Research.

When performing a comparison between FP7 and H2020 programmes we can easily identify the followings:

- The budget is larger for H2020 with approximately 25 billion euro;

- The components are different, as mentioned above;

- Funding rate for research has increased to $100 \%$ in $\mathrm{H} 2020$ versus $75 \%$ in FP7; 
- Funding rate for Demonstration/Innovation actions has also increase up to $70 \%$ in $\mathrm{H} 2020$ versus $50 \%$ in $\mathrm{FP} 7$, in $\mathrm{H} 2020$ the funding rate can also reach the $100 \%$ for non-profit organization for these types of projects;

- The overhead is fixed for all beneficiaries to $25 \%$ from direct cost

- Time to grant has reduced significantly to 8 months in $\mathrm{H} 2020$, from approx. 12 months in FP7.

In addition, H2020 is more focused on innovation, multidisciplinary projects, and SMEs [1].

This paper is structured as follows: in the first part, the reference literature and the methodology are presented. The second part analysed the former communist countries' participation to FP7 and $\mathrm{H} 2020$ with a special focus on Romania. The work ends with discussions and conclusions.

\section{LITERATURE REFERENCES AND METHODOLOGY}

The limited participation of the new member states to FP7 is highlighted by several publications such as Vught [2], Rauch and Sommer-Ulrich [3] and Galsworthy and McKee [4]. Among the causes mentioned in these studies there are: the quality of research and education establishments, the human, financial, and managerial capacities, the available infrastructure and the salaries level. MoagarPoladian, Folea and Paunica [5] analyse the competitiveness of the EU member countries during FP7 and partially $\mathrm{H} 2020$. They conclude that the new member states are less competitive than EU15 and confirm the causes mentioned by previous studies. Ukrainski et al. [6] evaluates the degree of segregation and integration of the new member states in FP7 and $\mathrm{H} 2020$ with the help of three indices: Index of dissimilarity, Index of isolation and Index of interaction. Their conclusions are that: segregation and isolation increased in $\mathrm{H} 2020$, and the probability of interacting with another member of the majority group (EU15 member) decreased. Regarding the direct distribution effects between Member States, driven by the two programs, the different nature of the collection, respectively the allocation of funds, is maintained. The funding sources of FP7 and H2O20 are the result of a political decision, and the allocation of funds is based on a competitive, independent process [7]. For this reason, the net distribution effect depends both on the research potential and the scientific quality of a specific country. For FP7, figures show that the net distribution effect is negative for Romania for FP7 [7] and H2020 [8]. In the following lines are presented the comparative results of these two programmes for Romania in the regional context. EC Funding and tender opportunities - Single Electronic Data Interchange Area (SEDIA) provides to all the beneficiaries all the relevant data on $\mathrm{H} 2020$ programme. It is an interactive knowledge platform that offers public access to statistics and data on EU research and innovation. Data were entered in a Microsoff ${ }^{\circledR}$ Excel $^{\circledR}$ spreadsheet and processed using the above-mentioned program. Romania is compared to the 12 former communist states that have undergone in the same way the process of transition to the market economy: Romania, Bulgaria, Czech Republic, Hungary, Finland, Croatia, Latvia, Lithuania, Estonia, Poland, Slovakia, and Slovenia.

\section{FP7 AND H2020 IN THE FORMER EUROPEAN COMMUNISTS COUNTRIES}

Within H2020 programme, up to $28^{\text {th }}$ of March 2020, the European Commission funded 27330 projects that sum a total EU contribution of 50.83 billion euro, the total cost of all these grants being 63,97 billion euro. Romania participated in 787 projects, representing $2.88 \%$ of $\mathrm{H} 2020$, the total number of participations being 1192 , representing $0.89 \%$ of $\mathrm{H} 2020$ participations, with 451 unique participants. Participations of EU 12 countries in H2020 and FP 7 is presented in figure 1.

Figure 1 shows that 7 out of 12 countries registered an increase of participations in $\mathrm{H} 2020$ compared to FP7, among these countries being Romania which saw an increase of $9.15 \%$. The cumulative weight of the total number of EU 12 participants rises from $9.58 \%$ to $9.67 \%$, but still remains below the most performing country, Germany, $13.5 \%$ and respectively $11.9 \%$. Finland and Poland are in the first places in terms of number of participations, given that the population of Poland is more than seven times larger. Still, the ranking does not change significantly between FP7 and $\mathrm{H} 2020$.

Regarding the Net EU Contribution, figure 2 shows that all the analysed countries registered increases, the smallest of these increases being in Hungary, of about $0.38 \%$ and the largest in Estonia of about $98.65 \%$

In total EU Contribution, the analysed countries rise from $5.91 \%$ to $6.88 \%$, but, cumulated, remain below the percent of the most performing country: Germany, that reached more than $15 \%$ in both programmes.

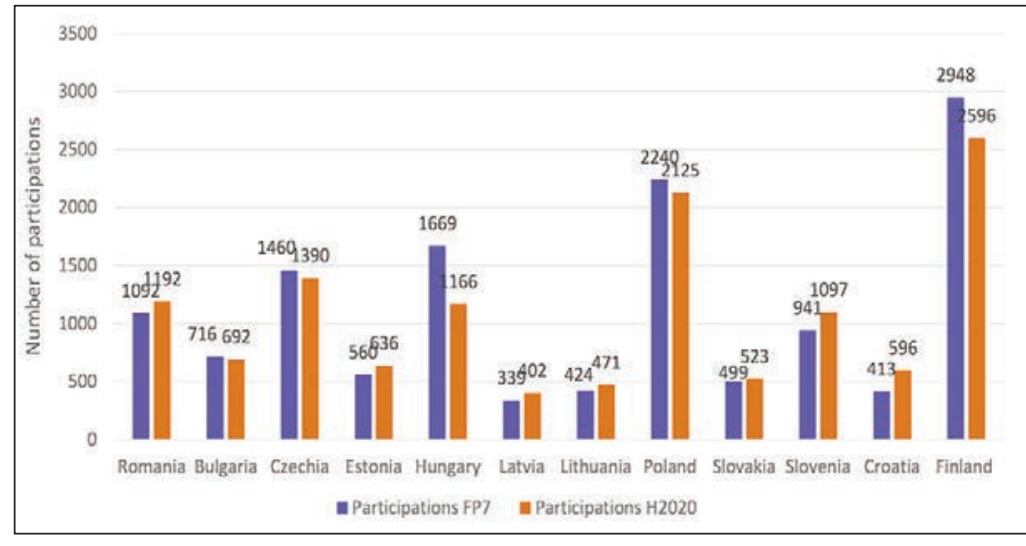

Fig. 1. EU 12 Participations in FP7 and H2O20 [9] 


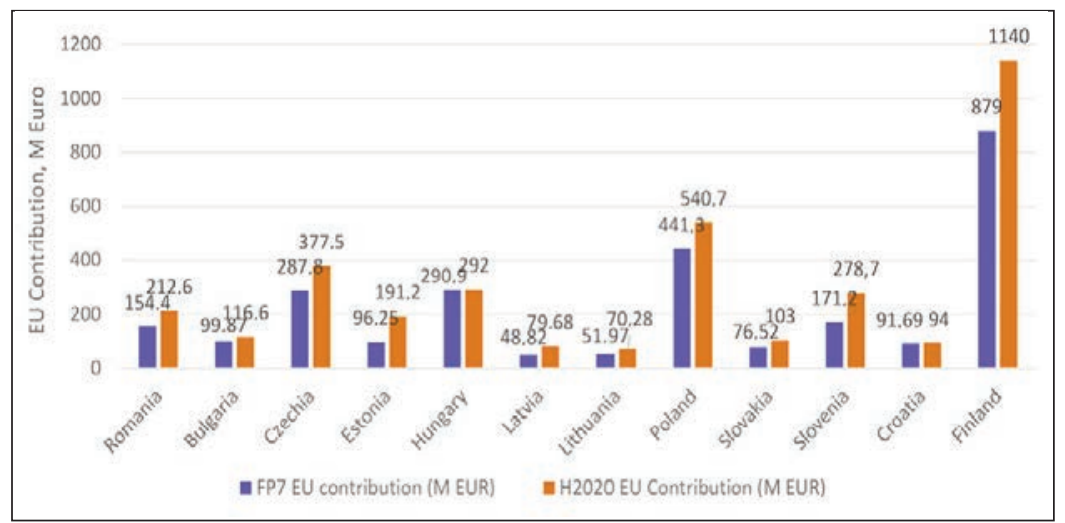

Fig. 2. FP7 and H2020 EU Contribution (M Euro) for EU12 [9]

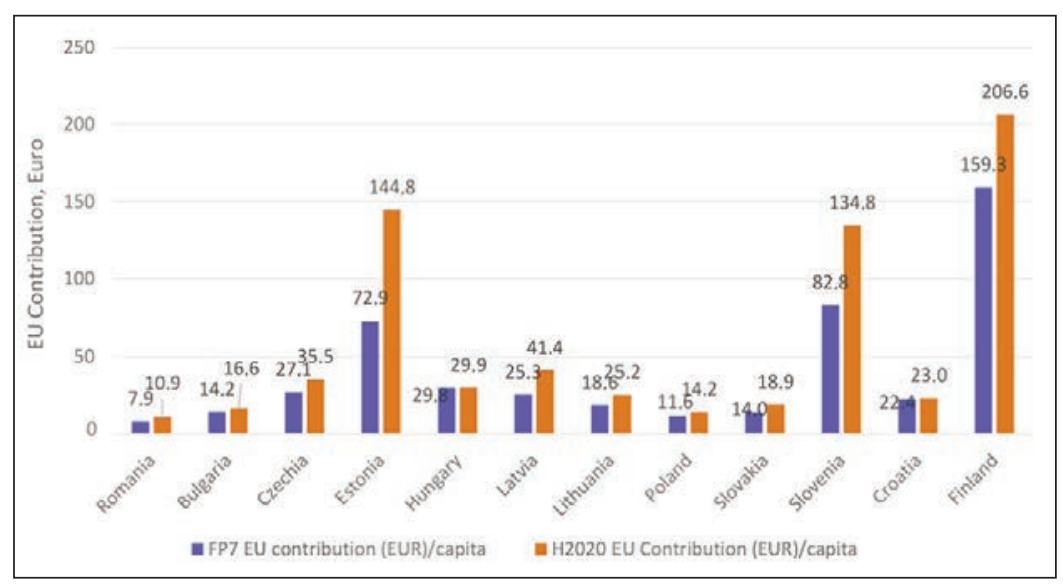

Fig. 3. EU Contribution/Inhabitant: FP7 and H2020 [9-10]



Fig. 4. Net EU Contribution/R\&D personnel, Full-time, FP7 and $\mathrm{H} 2020$ [9-11]

Romania also registered an important increase of the financing, of $37.69 \%$, above the regional average of approx. 30\%. EU 12 ranking changes if the EU contribution per inhabitant is clearly determined, as shown in figure 3.

It can be seen that Romania occupies the last place in the EU12, both for FP7, and H2020. The first three places are occupied by Finland, Estonia and Slovenia for both programmes. Between the FP7 and $\mathrm{H} 2020$ the ranking does not change much: Estonia, Latvia, Lithuania and Slovakia advance one place, and Hungary, Croatia and Bulgaria go down one place. Poland and Romania remain in the last two places. Regarding the productivity of the research activity measured by the researchers' ability to attract funding within the two analysed programs, the situation is presented in figure 4.

Figure 4 shows that the first three countries remain, in order, Estonia, Finland and Slovenia. Three countries go down significantly in this rank, cu 5, respectively 4 positions: Lithuania, Bulgaria and Poland, while Romania, Slovakia and Latvia are going up two places. On average, the productivity increases by $33.6 \%$, so for $\mathrm{H} 2020$ the average exceeds Germany. The gaps between the EU12 countries are very large,

with Estonia having this indicator 7.88 times larger than Poland. Thus, within the EU12 two groups of countries are distinguished: on one hand Estonia, Finland, Slovenia and Latvia with an equal or higher performance than Western Europe and the rest of the countries, with a lower performance.

\section{CONCLUSIONS}

The objective of this paper was to highlight the Romanian position in the former EU communist countries from the perspective of participating in the FP7 and H2020 research framework programmes. EU12 countries saw an increase of about $16.35 \%$ in participation in $\mathrm{H} 2020$, compared to FP7 in terms of net EU contribution. The number of participations increased less, the total share of these countries being $9.67 \%$ in $\mathrm{H} 2020$, compared with $9.58 \%$ in FP7, which confirms the conclusions of previous studies, namely that the new member states are less competitive compared to EU15. In the analysed group there are large gaps in terms of the efficiency of the use of human resources. Romania has improved its positions in the rankings, as follows: from the point of view of the number of participations, it moved from position 5 to $4^{\text {th }}$ position, and for the net EU contribution per R\&D personnel won two positions - from $9^{\text {th }}$ place to $7^{\text {th }}$ place. However, it remains on the $6^{\text {th }}$ position from the point of view of EU contribution and on the last place in Europe on the indicator of EU contribution per inhabitant. 


\section{ACKNOWLEDGEMENT}

This research was supported financially by the project CNFIS-FDI-2018-0582 - Supporting Excellence Research within The Bucharest University of Economic Studies in the context of the principles of sustainable development and open research. 6. Supporting field research excellence in universities Beneficiary: The Bucharest University of Economic Studies.

\title{
REFERENCES
}

[1] Vinnova, FP7 and Horizon 2020 - a comparative study of the support services in the Nordic countries, VINNOVA - Swedish Governmental Agency for Innovation Systems/Verket för Innovationssystem, 2013, Available at: https://www.vinnova.se/contentassets/7d05ced949354fe5bdc670f08d7b1a6a/va_13_16.pdf [Accessed February 2020]

[2] Vught, van F., The EU Innovation Agenda: Challenges for European Higher Education and Research, In: Higher Education Management and Policy, 2009, 21, 2, 1-22

[3] Rauch, M., Sommer-Ulrich, J., Participation of the Central and Eastern European EU Member States in the 7th Framework Programme: Analysis, Evaluation, Recommendations, Fraunhofer MOEZ Institute, 2012, Available at: http://www.moez.fraunhofer.de/en/publikationen/jcr:content/contentPar/textblockwithpics/linklistPar/download/file. res/MOEZ_summary_final.pdf [Accessed February 2020]

[4] Galsworthy, M., McKee, M., Europe's 'Horizon 2020' science funding programme: how is it shaping up?, In: Journal of Health Services Research \&Policy, 18(3) 182-185, Available at: https://www.ncbi.nlm.nih.gov/pmc/articles/ PMC4107840/pdf/10.1177-1355819613476017.pdf [Accessed February 2020]

[5] Moagar-Poladian, S., Folea, V., Paunica, M., Competitiveness of EU Member States in Attracting EU Funding for Research and Innovation, In: Romanian 150 Journal of Economic Forecasting, Institute for Economic Forecasting, 2017, 2, 150-167, Available at: https://ideas.repec.org/a/rir/romjef/vy2017i2p150-167.html [Accessed February 2020]

[6] Ukrainski, K., Kanep, H., Kirs, M., Karo E., Segregation of EU13 Countries in EU Framework Programmes Illuminates Important Challenges for Cohesion Policy, In: CeSifo Forum 19, 2018, 1, Available at: https://www.cesifo.org/DocDL/CESifo-Forum-2018-1-Ukrainski-EU-Cohesion-policy-march.pdf [Accessed February 2020]

[7] Fisch, P., Monetary (re-)distribution effects of FP7, In: Think Pieces, 2015, 2, Available at: https://www.peterfisch.eu/european-research-policy/think-pieces/2-2015-distribution-effects/ [Accessed February 2020]

[8] Fisch, P., Monetary (re-)distribution effects of Horizon 2020 - An updated analysis (June 2017), In: Think Pieces, 2015, 2, Available at: https://www.peter-fisch.eu/european-research-policy/think-pieces/2-2017-distribution-2017/ [Accessed February 2020]

[9] European Commission, Horizon dashboard, Available at: https://ec.europa.eu/info/funding-tenders/opportunities/ portal/screen/opportunities/horizon-dashboard [Accessed 28 th of March 2020]

[10] World Bank, World Bank open data, Available at: https://data.worldbank.org/ [Accessed $28^{\text {th }}$ of March 2020]

[11] European Commission, Eurostat, Available at: https://ec.europa.eu/eurostat/databrowser/view/tsc00003/default/ table?lang=en [Accessed $28^{\text {th }}$ of March 2020]

Authors:

\section{MONICA DUDIAN ${ }^{1}$, DANIELA VASILE ${ }^{2}$, MARGARETA STELA FLORESCU ${ }^{1}$}

${ }^{1}$ Bucharest University of Economic Studies, 6 Piata Romana, 010374, Bucharest, Romania email: margareta.florescu@ari.ase.ro

${ }^{2}$ National Institute for Research and Development on Marine Geology and Geo-ecology - GeoEcoMar, 23-25 Dimitrie Onciul Street, 024053, Bucharest, Romania email: danabiro@yahoo.com

\section{Corresponding author:}

\author{
MONICA DUDIAN
}

email: monica.dudian@economie.ase.ro 